UNIVERSIDAD NACIONAL DE LA PLATA

Facultad de Humanidades y Cs. de la Educación

Doctorado en Historia

\title{
LA DINÁMICA DE LA REALEZA EN \\ SOCIEDADES DE BASE CAMPESINA: \\ EL CASO VISIGODO EN LA PENÍNSULA \\ IBÉRICA, SIGLOS VI-VIII
}

SABRINA SOLEDAD ORLOWSKI

TESIS PARA OPTAR POR EL GRADO DE DOCTORA EN

HISTORIA

Director: Dr. CARLOS A. T. ASTARITA

Co-Director: Dr. Carlos G. García MaC GaW

ENSENADA, 28 DE NOVIEMBRE DE 2019 


\section{ÍNDICE}

Agradecimientos..................................................................5

Siglas y abreviaturas más frecuentes............................................. 6

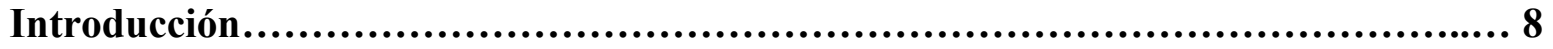

Capítulo 1. La dinámica política de la realeza de Toledo (s. VI-VIII). Balance historiográfico......................................................................13

-Sánchez Albornoz: protofeudalismo, gardingos y fideles regis como objetos de valoración............................................................. 16

-El feudalismo visigodo: origen de un constructo...............................18

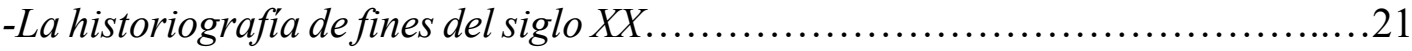

-La vigencia de los postulados de Barbero y Vigil en la historiografía actual ..........24

-Pervivencia de las estructuras estatales romanas en el reino visigodo de Toledo...27

-La Península Ibérica desde nuevas perspectivas. Arqueología y etnogénesis........31

Capítulo 2. El reino visigodo de Toledo, una formación social de base campesina......40

-Nota sobre el concepto de formación social.................................40

2.1) El modo campesino: modo dominante de la formación social del reino visigodo de Toledo. 42

2.2) El contexto material de la sociedad visigoda: las condiciones objetivas del hábitat rural

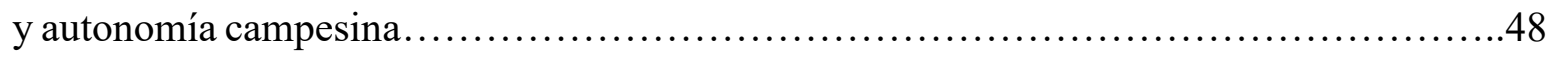


-Alcance y problemas de la contribución arqueológica a la historia rural visigoda...........................................................49

-El fin de las villas, el florecimiento de aldeas campesinas y los nuevos núcleos residenciales de la aristocracia ............................................51

Capítulo 3. La economía del reino y la economía regia...............................72

-Nota historiográfica y planteo del problema ................................... 72

3.1) Condicionantes económicos generales del reino visigodo de Toledo.................75

-Guerras, pestes, plagas y hambrunas...................................... 75

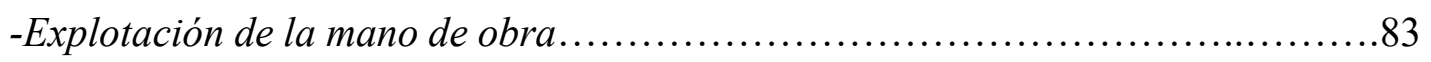

3.2) Las bases materiales del poder regio .................................... 93

-(I) Vias de enriquecimiento de los reyes godos: recaudación fiscal y explotación de

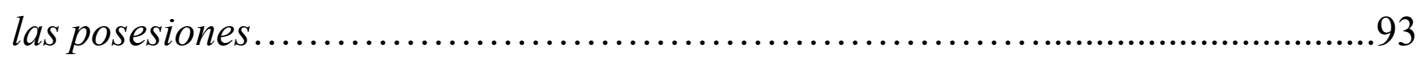

-(II) Vías de enriquecimiento de los reyes godos: botín de guerra, penas judiciales patrimoniales e incautación de los bienes de los particulares.....................102

Capítulo 4. La fragilidad política y la oscilación del poder regio......................111

4.1) La fragilidad del sistema político y la oscilación del poder regio en las fuentes y

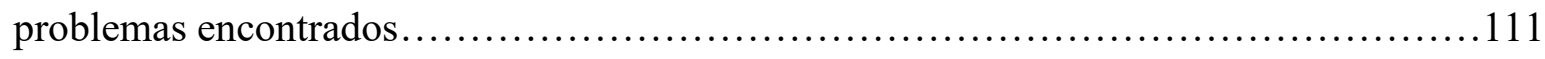

-Primer acercamiento..............................................111

-Los Concilios Eclesiásticos, las asambleas generales del reino visigodo: su valor documental para el estudio de los reyes y sistematización de los datos..............118

- El acceso al trono: fórmulas legales y formas legítimas.........................132

Capítulo 5. Reyes y aristócratas: fidelidad política y recompensas....................138

-Nota sobre la dominación carismática: análisis del concepto y su utilidad en el estudio de la dinámica de la dominación política de los reyes visigodos.

5.1) Primera aproximación a las relaciones intra-aristocráticas a través de sus conflictos.

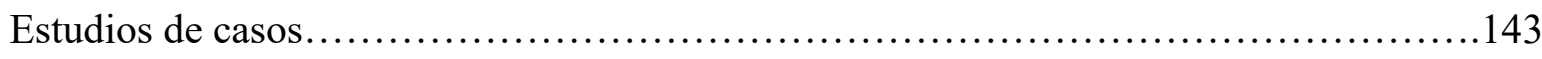

-Recaredo............................................................ 143 
Wamba. 151

5.2) La dinámica de la relación sociopolítica intra-aristocrática. El vínculo de fidelidad y la entrega de premios..............................................................

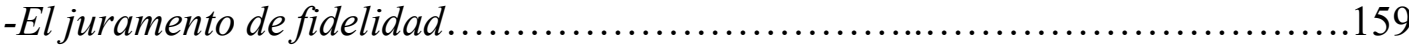

-Los fideles regis: identidad y funciones ........................................ 164

-Don y contradon: los fideles regis y la cercanía al rey

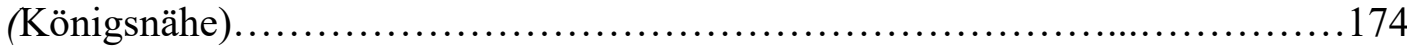

-La fidelidad rota: rupturas en el ápice del poder...............................185

Capítulo 6. Aristócratas y guerreros: aspectos de su relación........................189

6.1) Análisis de la producción historiográfica sobre el ejército visigodo de Toledo.......190

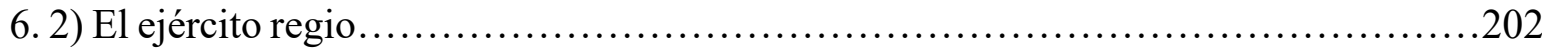

-Las bases organizacionales del ejército regio...............................203

-La extracción social de los guerreros-clientes.................................214

6.3) Los cambios de lealtad durante la guerra: la ruptura del vínculo guerrero-líder

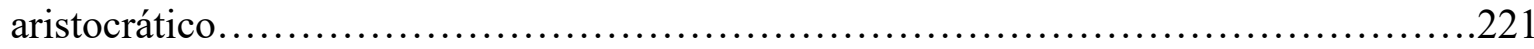

6.4) Las recompensas como nexo mediador de la relación política....................224

Capítulo 7. Reyes guerreros, reyes legítimos......................................236

7.1) La ideología legitimante del poder regio.....................................237

- La figura del princeps diseñado por la inteligencia católica .......................240

- Reyes guerreros......................................................248

Conclusiones generales.............................................................263

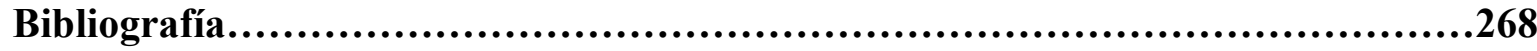




\section{AGRADECIMIENTOS}

En primera instancia, agradezco a la Facultad de Humanidades y Ciencias de la Educación, Universidad Nacional de La Plata, por ser mi casa de estudio; en especial al cuerpo docente de las carreras del Profesorado y Licenciatura en Historia. De ellos he aprendido el oficio de investigar y enseñar, y lo sigo haciendo. A las autoridades del Departamento de Historia, de este y de los años anteriores, por brindarme las oportunidades para desempeñarme como docente e investigadora.

Agradezco también al Consejo Nacional de Investigaciones Científicas y Técnicas (CONICET) por el apoyo económico y al CESP-IdIHCS por brindarme todo lo necesario para el desarrollo de mi investigación.

En segunda instancia, quiero expresar mi más profunda gratitud a Carlos Astarita, director de esta tesis. Agradezco su guía constante, su generosidad, sus palabras de aliento y su desinteresada ayuda en cada paso de mi carrera. De igual modo, a Carlos García Mac Gaw,

mi co-director, por depositar en mí su confianza y estimular esta investigación. A las profesoras Laura da Graca y Rosana Vassallo por marcarme un horizonte intelectual y por brindarme consejos siempre certeros, cálidos y con el único fin de animarme.

No quiero dejar de mencionar a Carla, Candela y María Emilia, mis grandes compañeras y amigas, aunque para ellas no tengo palabras. Sería mezquino reducir a una sola frase lo que significaron en este largo proceso de escritura y lo que son en mi vida.

A mi familia le agradezco toda su confianza y por seguir creyendo en mí a pesar de los obstáculos y el tiempo transcurrido desde que inicié esta investigación. Al final, ya casi no preguntaban por esta tesis, no por falta de interés sino por solidaridad, para no presionarme 
ni angustiarme. Por último, a Martín, Galatea y Lucio. Sin ellos este escrito hubiese sido un sinsentido.

\section{SIGLAS Y ABREVIATURAS MÁS FRECUENTES}

Concilios

$M G H$

Concilios visigóticos e hispanosromanos, ed. J. VIVES, Barcelona,

IOHAN BICL. Chr.

Madrid, 1963. Se abrevia Concilios, nombre del Concilio, año, canon (c.) y página.

IOHANNIS BICLARENSIS: Chronicon, ed. C. CARDELLE DE HARTMAN y R.

ISID. Hist. Goth. COLLINS, Corpus Christianorum Series

Latina, 115, Turnhout, 2001.

ISIDORUS HISPALENSIS: Historia

Gothorum, ed. C. RODRÍGUEZ, ALONSO, Las historias de los Godos,

IUL. TOL. $H W$

Vándalos y suevos de Isidoro de Sevilla, León, 1975.

IULIANI TOLETANI EPISCOPI, Historia Wambae, ed. W. LEVISNON, $L V:$ Corpus Christianorum Series Latina, 115, Turnhout, 1971. 
Lex Visigothorum, ed. K. ZEUMER, $M G H$, Legum sectio I, Leges nationum germanicarum I, Hannover, Leipzig, 1902. Se abrevia libro, título y número.

Vitas Sanctorum Patrum Emeretensium,

Monumenta Germaniae Historica A. MAYA SÁNCHEZ, Vitas Sanctorum Patrum Emeretensium, Corpus Christianorum Series Latina, 116, VSPE Turnhout, 1992. 


\section{INTRODUCCIÓN}

En nuestra tesis doctoral titulada La dinámica de la realeza en sociedades de base campesina: el caso visigodo en la Península Ibérica, siglos VI-VIII planteamos como hipótesis principal que la dinámica sociopolítica de los reyes en el reino de Toledo correspondió a lógicas de funcionamiento de las aristocracias en sociedades de dominación inestable, propias de la temprana Edad Media.

Los términos elegidos para definir el problema no son inocentes. Decidimos estudiar la dinámica política de los reyes utilizando una batería de conceptos teóricos que juzgamos

pertinentes y que serán desarrollados según corresponda. En las páginas que siguen apuntaremos la estructura de esta investigación y la lógica del ordenamiento que preferimos para exponerla.

Cuando nos acercamos por primera vez a la documentación visigoda con el objetivo de analizar el comportamiento de los reyes, uno de los aspectos que más despertó nuestra curiosidad fue el aumento y disminución de forma alternativa de la intensidad de su poder político, principalmente durante el siglo VII. Los datos referentes a las usurpaciones, destronamientos y revueltas aristocráticas son tan abundantes y constantes que motivaron a realizar esta tesis para dar cuenta de los principios estructurales que subyacían a este fenómeno de oscilación. Este fenómeno captura la atención de muchos investigadores, el aporte que pretendemos realizar consiste en comprender que las crisis de poder, lejos de ser sólo trances políticos o engranajes funcionales de la clase estamental dominante del reino, reflejaron una situación precaria de la aristocracia goda y fueron manifestaciones sensibles de una crisis del poder político.

Una vez detectado el problema y escogido el marco conceptual desde donde trabajarlo, nos enfocamos en el análisis de las fuentes y el estudio crítico de la bibliografía 
especializada. Este recorrido permitió detectar las siguientes constantes de la dominación inestable: 1) la fragilidad del sistema político y la oscilación del poder regio; 2) la precariedad de las bases materiales de la aristocracia y 3) la construcción permanente de la autoridad y del liderazgo de los reyes. Estas variables sumadas representan la inestabilidad del poder regio y del sistema de dominación. La complejidad de cada uno de estos elementos implicó la decisión metodológica de estudiarlos por separados, pero con el cuidado de no olvidar su intrínseca interrelación. Como resultado cada variable se desarrolla en distintos capítulos.

La Península Ibérica en el siglo VII es el escenario privilegiado en esta investigación. El periodo anterior (el reino godo de Tolosa y su desarticulación) y el posterior (la entrada de los árabes y su organización consecuente) son complejos, y con sus propios problemas históricos e historiográficos. La decisión de trabajar el largo siglo VII responde a la necesidad de resolver la hipótesis principal de forma exitosa.

El punto de partida será el análisis de las principales obras que desarrollaron sus argumentos en torno al problema planteado. Al finalizar el balance historiográfico, observaremos que la narrativa histórica no resolvió de manera positiva el problema de la inestabilidad de la realeza toledana. Algunos autores, como García Moreno, Céline Martin, Collins, no reconocen este problema; otros, como Barbero y Vigil, Valverde Castro y Díaz Martínez, Pérez Sánchez, Loring García y Fuentes Hinojo, lo entienden como situaciones fenotípicas de un sistema feudal, aunque no demuestran satisfactoriamente esta tesis. Ante este resultado, examinaremos la bibliografía que comprende la temprana Edad Media en un sistema socioeconómico específico en busca de un marco analítico propicio.

Wickham considera la temprana Edad Media como un periodo en el que los estados y la exacción económica fiscal fueron endebles y en el cual la aristocracia habría sufrido un proceso de empobrecimiento en términos de poder político y material, estableciéndose así espacios para una lógica campesina autónoma. A fin de comprender el funcionamiento de esta lógica formuló el concepto de sociedades de base campesina o modo de producción campesino. Debemos señalar que si bien este autor desestima aplicar las categorías de análisis que se desprenden del modo campesino al reino visigodo, creemos que sus premisas generales sobre el periodo tempranomedieval sí habilitan a realizar una lectura histórica que incluya a los godos en un universal europeo regido por la lógica que dicta el modo campesino. 
Por lo expuesto, en el capítulo dos analizaremos el concepto de modo de producción campesino reflexionando sobre su validez (y sus limitaciones) como herramienta analítica general. En especial razonamos sobre la categoría de reciprocidad, la lógica del don y el contradón y las implicancias de los términos dones agonísticos y no agonísticos en una sociedad de base campesina. El concepto de don es retomado a lo largo de la tesis, teniendo su desarrollo principal en el capítulo cinco. Asimismo, reconoceremos la importancia de entender al reino visigodo como una formación social de base campesina, jerarquizando el concepto de formación social.

El análisis teórico junto a la hipótesis principal de esta tesis nos obligará a estudiar las débiles relaciones de explotación. Leer de forma combinada los documentos escritos y el registro material proveniente de las excavaciones arqueológicas permite observar el predominio de unidades productivas autónomas y la práctica desaparición de estructuras agrarias de tipo antiguo. A su vez, destacaremos el protagonismo de un sector del campesinado libre que probablemente integraba las clientelas aristocráticas manteniendo con ella una relación de tipo laxa (y tal vez lograría erigirse como una elite local).

Continuando con la dimensión material, en el tercer capítulo determinaremos el contexto económico general del reino visigodo y especificaremos las bases materiales de sus reyes. Para comprobar que la aristocracia no dominaba a la clase productora de manera completa y, por lo tanto, no tenía aseguradas sus bases materiales de reproducción social, desarrollamos primero el contexto general económico y luego el problema del control de la mano de obra.

Por último, observaremos las bases materiales de los reyes. Concluiremos sobre su carácter restringido y su consecuencia más visible: la alteración de la entrega de premios por parte de los reyes a la aristocracia por la fidelidad política prometida. Con este planeo abriremos los capítulos restantes.

En el cuarto capítulo observamos la fragilidad del sistema político central y la oscilación del poder regio. Confirmaremos que las crisis de poder de los reyes eran sistémicas y no meramente acontecimentales. Llegados a este punto, en el quinto capítulo consideraremos la dinámica de las relaciones sociopolíticas entabladas entre la realeza y la aristocracia en Toledo, núcleo del poder central. La teoría del don y la noción de Königsnähe serán utilizadas junto a los conceptos weberianos de dominación inestable, dominación 
carismática y carisma; el potencial del término Herrshaft será puesto en un primer plano. Por medio de este conjunto de conceptos comprenderemos a las relaciones intra-arsitocráticas como vínculos regidos por la lógica reciprocitaria. Las reflexiones realizadas en el capítulo dos más las conclusiones sobre las bases materiales de la realeza cobrarán su total relevancia, pues la escasez de los bienes materiales perjudicaba notablemente la entrega de los premios $\mathrm{y}$, por lo tanto, las tensiones dentro de la aristocracia aumentaban generando los grandes conflictos. Ante esta difícil situación, los reyes aplicaban las armas de las confiscaciones, que constituyeron un instrumento político regido por la lógica de arrebatar/ ofrecer.

Comprobado que la aristocracia adepta al rey le otorgaba apoyo político materializado en tropas listas para entrar a la batalla a cambio de prerrogativas políticas y favores económicos y que la constitución de grupos armados fue una pieza clave en el juego político visigodo, el sexto capítulo está dedicado al estudio de la organización y composición social del ejército regio. Demostraremos que la aristocracia comandaba a sus propios guerreros, con los cuales establecía (sobre todo con los hombres libres) una relación de dependencia laxa mediada por recompensas. La relación de subordinación podría romperse si el jefe no cumplía con las expectativas prometidas. La relación hombre libre-aristócrata tuvo su paralelo con la del rey y la gran aristocracia, ya que ambas relaciones sociales compartían la lógica de la reciprocidad.

Es fundamental para nuestra investigación conocer el funcionamiento del ejército. En una sociedad donde los intentos violentos de usurpación fueron un peligro real, para los reyes visigodos fue vital convertirse en jefes, de modo temporal o permanente, de esos guerreros que compusieron el cuerpo del ejército, pues la fuerza militar fue una pieza clave de la construcción del poder regio.

Esto nos conduce al último capítulo. A pesar de la fragilidad institucional, la debilidad de las bases materiales, las relaciones políticas desiguales no cristalizadas y los abiertos conflictos aristocráticos permanentes, hubo reyes que gobernaron de forma exitosa. Este dato nos obliga a averiguar el soporte ideológico del poder regio. Aquí ampliamos el estudio sobre la última de las variables enunciadas.

Proponemos que la representación ideológica construida por la Iglesia sobre la legitimidad de los reyes fue una estrategia de construcción del poder regio. De forma paralela, comprobaremos que existió una ideología laica que tuvo un gran desarrollo. Como en todo 
Occidente temprano medieval, la cultura aristocrática laica visigoda fue de naturaleza guerrera, por lo cual no es extraño que los reyes demostraran atributos guerreros que les permitirían elevarse como los máximos líderes entre los aristócratas. Estas expectativas fueron reflejadas en un programa ideológico que tuvo sus propios ritos y formas de propaganda. 


\title{
CApítulo 1
}

\section{LA DINÁMICA POLÍTICA DE LA REALEZA DE TOLEDO (S. VI-VIII).}

\author{
BALANCE HISTORIOGRÁFICO*
}

En nuestra tesis doctoral titulada La dinámica de la realeza en sociedades de base campesina: el caso visigodo en la Península Ibérica, siglos VI-VIII planteamos como hipótesis principal que la dinámica sociopolítica de los reyes en el reino de Toledo se correspondió con lógicas de funcionamiento de las aristocracias en sociedades de dominación inestable, propias de la temprana Edad Media.

La historiografía altomedieval de los últimos años ha comenzado a sintetizar este periodo revelando categorías analíticas nuevas que permiten pensar la especificidad de la temprana Edad Media en su propia lógica de funcionamiento, lo cual enfatiza la visión de Europa como totalidad en oposición a los enfoques locales concordantes con la historia nacionalista ${ }^{1}$.

* En el cuerpo del texto se colocan el nombre completo de los autores solo en los casos de repetición de apellidos.

${ }^{1}$ Se oponen a enfoques localistas ASTARITA, C.: "Visiones nacionales en el medievalismo", Anales de Historia Antigua, Medieval y Moderna, Buenos Aires, 2008, vol. 40, pp. 119-150, WICKHAM, C. "Tradiciones nacionales y el problema de la comparación" Anales de Historia Antigua, Medieval y Moderna, Buenos Aires, 2008, vol. 40, pp. 11-24. Este autor considera que "Los historiadores europeos que no comparan casi siempre estudian su propio país, y esa atención reconcentrada sobre su espacio crea una Europa -un mundo- de islas, sin relación entre sí, en cada una de las cuales no sólo los patrones del cambio social sino también las preguntas que los historiadores formulan son absolutamente distintivas. Para empeorar las cosas estos aislamientos se corresponden, en casi todos los casos, con teleologías nacionales". Wickham considera esto como un solipsismo cultural, p. 11. Un primer acercamiento a este problema lo encontramos en WICKHAM, C.: "Problems of comparing rural societies in early medieval western Europe" en Land \& Power, Studies in Italian and European Social History, 400-1200, London, British School at Rome, 1994, p. 201 y ss; Versión en español: "Problemas de comparación de sociedades rurales en la Europa occidental de la temprana Edad Media”, Anales de Historia 
Los estudios abocados al análisis de la sociedad visigoda no son ajenos a este proceso. La caída del franquismo permitió una apertura académica que influenció en los historiadores españoles, a la vez que la historia de la Península Ibérica atrajo cada vez más historiadores no españoles ${ }^{2}$. En los últimos cuarenta años, sobre todo en los últimos veinte, el enfoque historiográfico nacionalista experimenta un proceso de abandono debido a los fuertes cuestionamientos que reciben las tradiciones narrativas que exaltan la nacionalidad y la pureza religiosa visigoda ${ }^{3}$. Los avances arqueológicos, las nuevas interpretaciones historiográficas y la revisita de las fuentes escritas contribuyen a esta tarea ${ }^{4}$.

Teniendo en cuenta este escenario, nuestro recorrido comenzará con el examen de los trabajos clásicos de Sánchez Albornoz, Thompson, King, García Moreno y Barbero y Vigil y sus seguidores. Luego analizaremos a los autores que adhieren a la corriente historiográfica que postula una continuidad de las estructuras tardo antiguas. Finalmente, nos concentraremos en la bibliografía de los últimos años, en especial la que comprende la sociedad visigoda en un sistema social específico de la temprana Edad Media europea.

\footnotetext{
Antigua y Medieval, Buenos Aires, 1996, vol. 29, pp. 45 y ss. Como veremos en el capítulo dos, los avances en la arqueología alentaron este enfoque. Asimismo, los proyectos conformados por historiadores de diferentes nacionalidades terminan en publicaciones que abarcan distintas regiones, haciendo que el enfoque nacionalista tenga un fuerte retroceso. Al respecto: STOCKING, R. L.: "Review article: Continuity, culture and the state in late antique and early medieval Iberia", en Early Medieval Europe, 15(3), 2007. WOOD, J. y MARTínEZ JIMÉNEZ, J..: "New directions in the study of Visigothic Spain", en History Compass 14.1, 29-38, 2016.

${ }^{2}$ Algunos ejemplos que representan lo dicho: HEATHER, P. (ed.): The Visigoths from the migration period to the seventh century, Woodbridge: The Boydell Press, 1999; MARTIN, C.: La géographie du pouvoir dans l'Espagne visigothique, Francia: Presses Universitaires du Septentrion, 2003; Collins, R.: La España Visigoda 409-711, Barcelona: Crítica, 2005.

${ }^{3}$ Para esta corriente de pensamiento, los visigodos son los protagonistas de uno de los capítulos más importantes de la vida de España como nación: ellos la dotaron de un territorio unificado, de una sola fe y de unas leyes unitarias (contraponiéndolo a la siguiente escena histórica: una España de dos religiones y numerosos reinos); la monarquía goda se presenta como hacedora de un estado centralizado, fuerte y autora de las bases institucionales, jurídicas y religiosas de toda España. Para este problema en especial: DíAz MARTíNEZ, P.C.: "Los godos como epopeya y la construcción de identidades en la historiografía española", en Anales de Historia Antigua, Medieval y Moderna, Buenos Aires, 2008, vol. 40, pp. 25-73.

${ }^{4}$ Linehan, P.: Historia e historiadores de la España medieval, Salamanca: Ediciones Universidad de Salamanca, 2012. Este libro analiza el proceso de apertura de la historiografía española vinculado con el proceso político, a la vez que cuestiona fuertemente a la narrativa tradicional. Ver especialmente sus capítulos uno y dos. Sobre los cambios historiográficos ver: STOCKING, R. L.: "Review article: Continuity, culture and the state in late antique and early medieval Iberia"; WOOD, J. y MARTínEZ JIMÉNEZ, J.: "New directions in the study of Visigothic Spain".
} 
Sánchez Albornoz: protofeudalismo, gardingos y fideles regis como objetos de valoración

Los trabajos de Sánchez Albornoz son una fuente ineludible para el estudio de casi cualquier aspecto de la historia española medieval, incluyendo la época visigoda. La exégesis documental y el uso de silogismos, la formulación de hipótesis -y la refutación de las de los demás-, el conocimiento de la historiografía internacional, y el análisis de los aspectos sociales -no sólo jurídicos- de las instituciones, son algunas de las cualidades que lo convierten en el autor institucionalista que aún se lee en el inicio de toda investigación. Además, Sánchez Albornoz ha instalado gran parte de los postulados sobre la historia visigoda que discuten los historiadores españoles de las últimas décadas.

En sus investigaciones plantea que las instituciones vasallático-beneficiales constituyeron el rasgo central del feudalismo. A partir de esta premisa caracteriza a la sociedad visigoda como protofeudal y protobeneficial, pues no constata la existencia plena de vasallos ni feudos más que de forma precaria.

En el análisis realizado sobre las instituciones visigodas que vinculaban al rey con sus seguidores o "vasallos", Sánchez Albornoz admite la existencia de una doble fidelidad: una general de todos los súbditos, y una segunda más estrecha y cercana al círculo íntimo regio; esta última prometida por los leudes, fideles y gardingos. Ambos vínculos diferían en origen y naturaleza. De esta manera, se opone a Manuel Torres, quien presume que los vocablos leudes y fides se aplicaban a todos los súbditos ${ }^{5}$.

Según lo dicho, el primer tipo de fidelidad que se le debía al rey fue la ordenada por el peso imperante del derecho público de un estado "romanizante visigodo"'. En este marco todos los habitantes del reino, de manera general nominados fideles regis, debían prometer, hipotéticamente, no traicionar a la causa ni a la persona del rey. Para el autor el origen de este tipo de fidelidad residía en los vigentes ritos imperiales y en la tradición jurídica romana. Sin embargo, advierte que por debajo de esa "superestructura estatal" " la aristocracia goda mantenía intacto su derecho vernáculo. El vínculo de fidelidad de condición germana fue un ejemplo, entre tantos, de ello.

\footnotetext{
${ }^{5}$ Este tema es ampliado en el capítulo 6.

${ }^{6}$ SÁNCHEZ AlbornOz, C.: En torno a los orígenes del feudalismo, Mendoza, 1942, t. 1, p. 71.

${ }^{7}$ SÁNCHEZ Albornoz, C.: "Pervivencia y crisis de la tradición jurídica romana en la España goda", en Viejos y nuevos estudios sobre las instituciones medievales españolas, II, Madrid, 1976, p. 1016.
} 
La comitiva privada regia estaba compuesta por los fideles regis, los seniores y comites palatii y gardingos, que se vinculaban al rey por medio de un juramento de lealtad de forma "especial, espontánea y personalísima" 8 prometiendo fidelidad, sincero servicio, vigilancia y custodia, y marchar a la guerra. Este autor, acudiendo a los escritos de Tácito, al poema de Beowulf, a las sagas nórdicas, y a los textos jurídicos y cronísticos de los pueblos bárbaros asentados en las tierras otrora romanas (lombardos, francos, ostrogodos, etc) realiza una comparación con los datos obtenidos de los documentos visigodos y concluye que el clásico comitatus de origen germano pervivía en la monarquía toledana, más precisamente en la institución del gardingato. Incluir documentación y bibliografía de otras regiones europeas responde a una de las ideas centrales de Sánchez Albornoz: el reino de Toledo compartía características centrales con los otros reinos romanos-germánicos, y principalmente con el reino merovingio; la singularidad de España surgió una vez comenzada la Reconquista de los territorios, a la sazón visigodos, invadidos por los árabes.

Para este autor, los gardingos formaban el círculo íntimo del rey constituyendo una prolongación histórica del comitatus germánico, por lo cual los gardingos probarían la persistencia del elemento godo en la sociedad hispana de los siglos VI y VII. De todos los miembros del cortejo, los gardingos fueron los más próximos al rey. A partir de la etimología de la palabra gardingus (que deriva del vocablo gards que significa casa o corte) el autor proclama que compartían la intimidad doméstica del monarca. A estos leales regios los caracteriza como aristócratas jóvenes y guerreros a caballo, que combatían junto y por el rey; habían sido los que entraban al círculo monárquico para constituir la guardia más ferviente, y que poseían como misión de oficio custodiar y vigilar a la persona del rey. No los identifica como miembros del Aula Regia ni del Oficio Palatino, aunque les reconoce los mismos privilegios de aquéllos; sí considera que pertenecer al círculo regio más propincuo equivalía a ser premiado con mercedes, lo cual posibilitaba entrar en la espiral social ascendente de los oficios administrativos del reino.

Finalizada la demostración sobre la naturaleza del vínculo de los fideles regis y, de esta manera, comprobado el protovasallaje, Sánchez Albornoz examina sobre las características de las mercedes dadas como beneficios por los reyes a sus seguidores más

\footnotetext{
${ }^{8}$ SÁNCHEZ Albornoz, C.: En torno a los orígenes del feudalismo..., p. 71.
} 
fieles. Preocupado por hallar la figura jurídica que enmarcase la entrega de estas mercedes, explora las fuentes visigodas.

En varios de sus textos más jóvenes ${ }^{9}$, sostiene que los reyes godos otorgaron, junto con las donaciones en plena propiedad, premios iure precario. Contra las teorías de Ernest Levy sobre la desaparición del precarium en Occidente después del siglo IV, Sánchez Albornoz estima que las mercedes concedidas por los reyes a sus leales seguidores sean in stipendio, sub stipendio o causa stipendii, eran "gratuitas, de plazo incierto y revocables"10. Por otro lado observa la continuidad de las donaciones restringidas y temporales, es decir, una supervivencia de la institución del precarium clásico $^{11}$. Del mismo modo, registra la existencia de un verdadero beneficio de origen militar: los hombres libres que participaban en la guerra -no necesariamente miembros del estrecho círculo regio- recibían recompensas en metálico o tierras como stipendia.

Sánchez Albornoz encuentra en los beneficios iure precario entregados por los monarcas a sus fideles y gardingi un protobeneficio, por lo tanto, un feudalismo embrionario malogrado por la invasión árabe y, posteriormente, distorsionado por la empresa nacional de la reconquista ${ }^{12}$.

Además, precisa que la construcción del poder de los reyes visigodos fue cercenada por la lógica feudal o protofeudal preponderante (constatada en el protovasallaje y el protobeneficio): los fideles regis constituyeron la base de apoyo del monarca, y en contraprestación recibieron donaciones de bienes y premios. Sin embargo, esta conducta engendraba el peligro de crear nuevos focos de dominio social y atizar otros (basados en relaciones clientelares) que hubieran podido llegar a competir con el propio rey haciendo

\footnotetext{
${ }^{9}$ Principalmente en el capítulo "Remuneración de los gardingos: el beneficio visigodo" del libro En torno a los orígenes del feudalismo visigodo, (primera parte): Fideles y Gardingos en la monarquía visigoda, Mendoza, 1942; en el artículo "El precarium en Occidente durante los primeros siglos medievales", en Viejos y nuevos estudios sobre las instituciones medievales españolas, II, Madrid, 1976; y en el estudio El «Stipendium» Hispano-Godo y los orígenes del beneficio prefeudal. Buenos Aires, Instituto de Investigaciones Históricas. Departamento de Historia de España, 1947.

10 SÁnchez Albornoz, C.: "España y el feudalismo carolingio", en Viejos y nuevos estudios sobre las instituciones medievales españolas, II, Madrid, 1976, p. 1260.

${ }^{11}$ En 1977 escribe un corto artículo en donde ni afirma ni desmiente los postulados sobre las cesiones iure precario a la luz de las cítricas y nuevas investigaciones. SÁNCHEZ AlBORNOZ, C.: "¿Donaciones reales restringidas en la España goda y postvisigoda?", Separata Homenaje a Don José María Lacarra de Miguel en su jubilación del profesorado, Vol. I, Zaragoza 1977.

${ }^{12}$ SÁnCHeZ AlbornOZ, C.: "España y el feudalismo carolingio”..., p.1276.
} 
débil a la institución regia. Esta idea es retomada por muchos de los historiadores, quienes cambian algunos elementos, pero conservando la idea central.

Ciertamente, esta demostración no cuestiona las causas profundas de este comportamiento. Constituye una explicación del funcionamiento de la lógica del poder, mas no del inicio del movimiento que origina ese comportamiento febril.

El razonamiento del historiador abulense sobre la naturaleza de la monarquía goda es decir sobre el vínculo hombres libres- aristocracia- está signado por la búsqueda de la terminología jurídica que la justifique; como consecuencia el análisis sobre la estructura y la dinámica social es limitado. Esta metodología constituye un modelo para las siguientes generaciones de historiadores españoles, tanto para sus seguidores como para sus detractores, quienes se oponen menos por las diferencias argumentales y de método que por las diferencias políticas. El estudio de Barbero y Vigil es un claro exponente de lo segundo.

\section{El feudalismo visigodo: origen de un constructo}

Barbero y Vigil plantean la existencia de feudalismo en el reino visigodo de Toledo. Para estos dos autores las relaciones de dependencia económica fueron un fenómeno extendido. La población de condición social inferior, independientemente del estatus jurídico, se hallaba subordinada a una aristocracia, tanto laica como eclesiástica, que conjugaba las personerías del dominus y del patronus unificando "la dependencia económica o material a la personal o extraeconómica" ${ }^{\prime 13}$. A partir de esta realidad económica y social se estructuraba un aparato político, jurídico e ideológico feudal (el estado visigodo). Los autores fundamentan la presencia de las relaciones de dependencia en la terminología empleada en los libros legales y eclesiásticos y en su amplia difusión.

En este contexto, los reyes godos (según Barbero y Vigil, los artífices de la unidad estatal y legitimantes de la situación privilegiada de la nobleza ante el resto del pueblo), socavados en su dominio por el actuar de las facciones nobiliarias, debían erigirse como los mayores propietarios de tierras y de bienes muebles, y crear un ejército numeroso con dependientes privados o clientes. El monarca debía ser

\footnotetext{
${ }^{13}$ Barbero, A. \& Vigil, M.: La formación del feudalismo en la Península Ibérica, Barcelona: Crítica, 1978. p. 22.
} 
“el dominus y el patronus más importante del reino desde el punto de vista privado y extender estas relaciones de dependencia privada al plano político en lo que respecta a los súbditos" $"$.

De esta manera, los hombres de sus propias fincas y los pertenecientes a las tierras del fisco integraban una única relación de dependencia, perdiéndose la distinción entre lo público y lo privado. Barbero y Vigil aseveran que este proceso de feudalización culminó con la institucionalización de una monarquía "feudal, patrimonial y hereditaria" 15 , aspectos que se condijeron con la realidad de los cargos palatinos hereditarios y permanentes bajo control aristocrático.

El carácter de las donaciones regias fue otra marca de feudalidad. En contra de la tesis de Sánchez Albornoz sobre la pervivencia del precarium, Barbero y Vigil proponen que los premios y bienes adjudicados por el rey a sus fieles quedaban en perpetuidad y plena propiedad del beneficiario; sólo en caso de infidelitas o perfidia procederían a su confiscación ${ }^{16}$.

Según los argumentos de Barbero y Vigil, las revueltas nobiliarias contra el centro y las destituciones regias - por lo tanto la inestabilidad política de los reyes-son interpretadas como situaciones fenotípicas de un sistema feudal.

Es interesante advertir que, desde el prólogo, los autores anuncian que se servirán de una metodología que supere la utilizada por las corrientes institucionalistas; sin embargo, al observar la forma en que fundamentan sus postulados el lector encuentra una extensa glosa sobre terminología jurídica ajustada a los parámetros delineados con anterioridad ${ }^{17}$. Por ejemplo: los vínculos de dependencia son inferidos del vocabulario de los textos jurídicos sin una crítica documental que permita estimar el alcance de las relaciones de producción propuestas. De hecho, la tesis de un feudalismo visigodo presupone la existencia de una fuerte aristocracia fundiaria. Curioso es que el libro no gire sobre este tópico sino sobre

\footnotetext{
${ }^{14}$ Ibidem, p. 106.

${ }^{15}$ Ibidem, p. 200.

${ }^{16}$ Ibidem, p. 119 y 107 y ss.

17 Una crítica similar la hallamos en: FERNÁNDEZ UBIÑA, J.: “Clasicismo y fin del mundo antiguo", en "Romanización" y "reconquista" en la Península Ibérica: nuevas perspectivas, 1998, pp.191-213.
} 
aquellos elementos institucionales que reflejan las relaciones feudales (la composición del ejército y los elementos militares; las donaciones y estipendios regios; la fidelidad como vínculo político; la naturaleza de los fideles regis; la ideología como elemento de legitimidad y la transmisión del poder regio, es decir, el sistema sucesorio) y no sobre las relaciones de producción feudales. Destacamos que los aspectos jerarquizados por Barbero y Vigil son los mismos que trató Sánchez Albornoz. Juzgamos que el libro de Barbero y Vigil contiene una enérgica intertextualidad con la obra del abulense, y que si bien pretende ser una diatriba contra aquella tradición historiográfica reitera sus mismos métodos. Es interesante señalar que en los capítulos exclusivos sobre el reino astur los autores utilizan una metodología empapada de conceptos antropológicos, método de investigación ausente en el análisis sobre la sociedad visigoda.

No podemos negar que la aparición del libro de Barbero y Vigil marca un hito historiográfico en España por su carácter combativo frente a los postulados tradicionales y por su tesis peculiar sobre el feudalismo español. Por estos motivos la tesis de Barbero y Vigil ha sido (en gran medida) y es (cada vez menos) un horizonte para los visigotistas, principalmente en el ámbito español ${ }^{18}$. A medida que los años pasan, la tesis del feudalismo visigodo está perdiendo influencia en las actuales investigaciones.

Como conclusión parcial, observamos que la debilidad de la tesis del feudalismo visigodo radica en que se presuponen dos afirmaciones: 1) la mayoría de los campesinos eran dependientes de la aristocracia en términos de extracción económica y obediencia personal y 2) los grandes del reino poseían fuertes bases materiales que constituían una poderosa fuerza social que les permitía disputar el control político y enfrentarse al rey en favor de sus propios intereses (que distaban de los intereses del orden público). Como hemos visto, estos presupuestos no están debidamente fundamentados, lo cual le quita autoridad a la tesis del feudalismo visigodo ${ }^{19}$.

\footnotetext{
${ }^{18}$ José María Mínguez Fernández deja entrever en su artículo del año 2004 que la revisión de las tesis de Barbero y Vigil es un tema tabú en los ambientes científicos peninsulares. En: Mínguez FERnÁNDEZ, J. M.: "En torno a la génesis de las sociedades peninsulares altomedievales: reflexiones y nuevas propuestas", Studia historica. Historia medieval, 22, 2004. (Ejemplar dedicado a: En memoria de Ángel Barrios García (1951-2005), pp.169187.

${ }^{19}$ Mínguez Fernández también cuestionó fuertemente a la tesis de Barbero y Vigil. Plantea que el juramento de fidelidad que debieron todos los hombres libres al rey fue una promesa de origen público de defender al reino, y niega la equiparación de las condiciones de explotación entre los ingenui, los ingenui in obsequio vel
} 


\section{La historiografía de fines del siglo XX}

En las décadas de los setenta y ochenta, E.A. Thompson y King marcaron problemas historiográficos sobre el reino visigodo; y desde 1970 hasta ahora, García Moreno y Collins lo hacen siguiendo líneas de investigación tradicionales.

La obra de E.A. Thompson (estructurada a partir de la lista de los reyes visigodos) privilegia como eje central el problema de la etnicidad; su análisis comienza con la entrada de los visigodos en tierras ibéricas. Apunta que las diferencias entre godos y romanos, "las nacionalidades", más las diferencias religiosas fueron los elementos que dinamizaron la evolución social. De hecho, separa la historia visigoda en un periodo arriano y otro católico ${ }^{20}$.

Desde una perspectiva jurídica, propone que el triunfo de los godos marcó el desarrollo institucional. Los nobles controlaron el reino con ayuda de los obispos, quienes a través de las leyes canónicas y distintos escritos fortalecieron el dominio regio. Asimismo, los señores del palacio y los gardingos apoyaban a los reyes a cambios de premios $^{21}$. La obra de Thompson marcó a varias generaciones de historiadores, y en la actualidad sigue vigente ${ }^{22}$, más por las conjeturas sobre algunos hechos específicos que por su lectura estructural del periodo.

Desde un punto de vista de la historia jurídica institucional, King observa la relación entre las leyes y la sociedad ${ }^{23}$. Sinteticemos sus ideas centrales sobre el reino visigodo, en particular sobre la dinámica política, - las cuales retomamos para su discusión en las secciones correspondientes-.

patrocinio constituti y los servi. Mínguez FERnÁNDEZ, J. M.: “En torno a la génesis de las sociedades peninsulares altomedievales: reflexiones y nuevas propuestas"; "Sociedad esclavista y sociedad gentilicia en la formación del feudalismo asturleonés". En: "Romanización" y "reconquista" en la Península Ibérica: nuevas perspectivas, 1998, pp. 283-302; Las sociedades feudales, 1, Madrid: Nerea, 1994.

${ }^{20}$ Este esquema expositivo es muy utilizado en las obras síntesis de la historia visigoda.

${ }^{21}$ ThOMPSON, E.A.: The goths in Spain, Oxford: Oxford University Press, 1969, pp. 252 y ss.

${ }^{22}$ Pérez Sánchez Dionisio sigue de cerca las ideas de Thompson, PÉREZ SÁNCHEZ, D.: El ejército en la sociedad visigoda, Salamanca: Universidad de Salamanca, 1985, p. 31. Por ejemplo: DíAz MARTínEZ, P.C.: "La dinámica del poder y la defensa del territorio: para una comprensión del fin del reino visigodo de Toledo", De Mahoma a Carlomagno: los primeros tiempos (siglos VII-IX) /XXXIX Semana de Estudios Medievales, Estella, 17-20 de julio de 2012

${ }^{23}$ KING, P.D.: Derecho y sociedad en el reino visigodo, Madrid: Alianza, 1981, p. 13. El autor sostiene que “(...) ninguna otra fuente es más indicativa que la ley como espejo de las aspiraciones e ideales de la sociedad la crea o, al menos, de los grupos dirigentes de esa sociedad”. 
La base ideológica del poder regio fue teocrática. Considera que los postulados de gobierno se basaban en Dios; asimismo, las leyes exclusivas referidas a los reyes los elevaban a un lugar cuasi-divino ${ }^{24}$. Por otro lado, al finalizar el análisis de la entrega de premios y concesiones de tierra a cambio de un servicio militar concluye que

“(..) el rasgo fundamental del feudalismo en su sentido más estricto, militar, existió ya en el reino visigodo del siglo VII: si no podemos llamar feudal al estado visigodo, podemos al menos, hablar con razón de feudalismo visigodo" 25 .

Otra idea que desarrolla versa sobre la relación entre los clientes y patrones. Entiende que los individuos libres encomendados, los cuales recibían ganancias por sus servicios, pueden ser caracterizados como los vasallos feudales del periodo posterior ${ }^{26}$. King encuentra apoyo en los escritos de Sánchez Albornoz para sostener sus hipótesis.

En los años sesenta y setenta del siglo XX — aun con cierta vigencia en todo el resto del siglo_- José Orlandis se perfiló como un académico notable dentro de la escuela eclesiástica. Propone a la Iglesia como el núcleo organizacional de la sociedad visigoda. En cuanto a la vigencia de esta corriente de pensamiento en la actual historiografía, Loring García entiende que existen un número importante de historiadores que remarcan la influencia estructurante de la Iglesia sobre la sociedad goda, aunque por cierto, alejados del "mito de la Iglesia como fundamento de la nación española" 27 . Sin embargo, no específica a qué autores contemporáneos hace referencia. Por nuestra parte, creemos posible enmarcar en este cuadro de pensamiento a Orlandis y a García Moreno ${ }^{28}$, heredero del jesuita ${ }^{29}$, historiador ecléctico vigente en la historiografía actual. Su trabajo sobre el periodo es extenso, el cual retomamos a lo largo de esta tesis. Aquí solo enunciaremos sus principales ideas.

\footnotetext{
${ }^{24}$ Ibidem, p. 59.

${ }^{25}$ Ibidem, p. 81.

${ }^{26}$ Ibidem, p. 212.

${ }^{27}$ LORING, Ma. I., PÉREZ, S. Y FUENTES, P.: La Hispania tardorromana y visigoda. Siglos V-VIII, Madrid: Editorial Síntesis, 2007, p. 342.

${ }^{28}$ Céline Martin enmarca a García Moreno cerca de las filas de la Iglesia en: MARTIN, C.: "L'historiographie des élites en Espagne”. Disponible en: http://lamop.univ-paris1.fr/fileadmin/lamop/publications/Haut-MoyenAge_Elites/HMA_elites_Espagne_Martin_2003.pdf

${ }^{29}$ Así lo considera Collins en: Collins, R.: La Europa de la Alta Edad Media, Madrid: Akal, 2000 p. 266.
} 
Según García Moreno, el reino visigodo puede ser entendido como protofeudal. En primer lugar, establece que la realeza, para protegerse de la levantisca nobleza, adoptó formas sacras con el beneplácito de la Iglesia, quien se erigió como tutora de los reyes ${ }^{30}$. A su vez, copiaron los modelos del estado bizantino, y se produjo una militarización de las estructuras administrativas. Otro elemento fundamental fue el lazo de fidelidad que unía a los miembros de la nobleza, que se sustentaba en la entrega de cargos y premios. Esto implicó que los miembros de la nobleza más encumbrada monopolizasen los cargos administrativos cedidos, lo cuales sufrieron una patrimonialización. Esta estructura tuvo su correlato en la dimensión socioeconómica; observa que el fenómeno de la encomendación campesina en la gran propiedad fue extendido ${ }^{31}$.

La perspectiva de estos tres autores sobre el reino visigodo se ha abandonado ${ }^{32}$, sin embargo, siguen siendo muy citados sus trabajos porque se utilizan como sostén en cuestiones muy específicas.

Collins ha publicado varias obras sobre el periodo visigodo ${ }^{33}$. El principal tópico historiográfico que pretende derribar es el modelo de un estado visigodo sumergido en la decadencia moral. Analizando la historia política del reino visigodo a partir del establecimiento godo en la Península Ibérica, considera que la monarquía fue una institución relativamente estable hasta la derrota con los árabes. Esta estabilidad procedería de las alianzas que los reyes lograron con las aristocracias locales (aspecto poco trabajado por él) a través del liderazgo militar, y de la concentración del poder por parte de un círculo muy

${ }^{30}$ García MorenO, L.A.: Historia de la España visigoda, Madrid: Cátedra, 1989, p. 324 y ss.

${ }^{31}$ GARcía Moreno, L. A.: "El estado protofeudal visigodo: precedente y modelo para la Europa carolingia", en L'Europe héritière de l'Espagne wisigothique [en línea], Madrid, Casa de Velázquez, 1992 (generado el 07 juin 2019). Disponible en Internet: <http://books.openedition.org/cvz/2107>. ISBN: 9788490960981.

${ }^{32}$ Collins en el 2004 critica duramente a García Moreno: "Dado que nunca se ha sugerido que «el sistema feudal» existiera en el siglo VII, y no digamos en el siglo V, y que por lo tanto el estudio del feudalismo no ha formado parte de la historiografía de la Galia merovingia, la Italia ostrogoda o la Inglaterra anglosajona, podría haber sido de esperar que el período visigodo dentro de la historia de España se evitara el embrollo de esta nueva obsesión académica. Por desgracia como si se tratara de demostrar que estas cosas son contagiosas, se ha iniciado una caza para encontrar pruebas de la existencia del llamado «protofeudalismo», una forma ancestral del fenómeno posterior. Actualmente esta creencia parece ser obligatoria, pero no ha resultado útil para hacer un estudio serio de este período. El «protofeudalismo» no es el único horror lingüístico engendrado por el actual deseo de los historiadores españoles de demostrar que son buenos europeos." Collins, R.: La España Visigoda 409-711, pp. 13 de la Introducción.

${ }^{33}$ Collins, R.: La España Visigoda 409-711. Collins, R.: Early medieval Spain. Unity in diversity (4001000), Hampshire-Londres, Mac Millan Press, 1995. 
reducido de familias. También examina el proceso de reconfiguración de las identidades étnicas y la posesión del tesoro regio como elemento definitorio de identidad política. Su análisis organizado a través de la sucesión de los hechos políticos dificulta a valorización de su obra, y la relación existente entre los reyes y la aristocracia es abordada de forma muy sucinta.

La vigencia de los postulados de Barbero y Vigil en la historiografía actual

Los herederos de Barbero y Vigil utilizan la matriz explicativa del feudalismo visigodo en sus propias investigaciones. Entre los exponentes más importantes podemos nombrar a Pérez Sánchez, Loring García, Fuentes Hinojo, Valverde Castro y Díaz Martínez.

Los primeros tres autores $\operatorname{citados}^{34}$ plantean que la organización militar basada en ejércitos integrados por los dependientes de los nobles, los vínculos de fidelidad y las representaciones ideológicas legitimantes del poder, los problemas sociales (como el bandidaje, saqueos, robos y revueltas) protagonizados por la clase campesina dependiente y la organización fiscal poseían la impronta de un avanzado sistema feudal. Con respecto a la inestabilidad regia, plantean que ha sido el reflejo de una sociedad feudal en la cual la monarquía, debilitada como consecuencia de la lucha por “(...) el control de los bienes de la Corona sometidos a un irreversible proceso de patrimonialización (...)"35, se enfrentaba a

\footnotetext{
${ }^{34}$ PÉREZ SÁNCHEZ, D.: El ejército en la sociedad visigoda; "Problemas sociales del reino visigodo de Toledo". En: Studia historica. Historia antigua, 1, 1983, pp. 105-118; "Defensa y territorio en la sociedad peninsular hispana durante la antigüedad tardía (ss. V-VII)”. En: Studia historica. Historia antigua, 16, 1998 (Ejemplar dedicado a: Sociedades y fronteras en el Mundo Antiguo), pp. 281-300; "Las transformaciones de la Antigüedad Tardía en la Península Ibérica: Iglesia y fiscalidad en la sociedad visigoda”. En: Studia historica. Historia antigua, 17, 1999 (Ejemplar dedicado a: Estudios de Economía Antigua en la Península Ibérica. Nuevas aportaciones), pp. 299-320; "Poder político y dominación social: la función justificativa de los ángeles en el mundo visigodo". En: Studia historica. Historia antigua, 26, 2008 (Ejemplar dedicado a: La ecúmene romana: espacios de integración y exclusión), pp. 187-217; "Legislación y dependencia en la España visigoda". En: "Romanización" y "reconquista" en la Península Ibérica: nuevas perspectivas, 1998, p. 227-246. LORING, M". I. Y FUENTES HINOJO, P: "Esclavitud y servidumbre en el tránsito del mundo antiguo al medieval”, en "Romanización" y "reconquista" en la Península Ibérica: nuevas perspectivas, 1998, pp. 247-256; FUENTES HINOJO, P.: "La pareja real y los problemas sucesorios en los reinos romano-bárbaros", La familia en la edad media: XI Semana de Estudios Medievales, Nájera, del 31 de julio al 4 de agosto de 2001,pp. 455-470. En el año 2007 editan en conjunto un libro el cual encierra los núcleos principales de cada uno de sus artículos: LORING, Ma . I., PÉREZ, S. Y FUENTES, P.: La Hispania tardorromana y visigoda. Siglos V-VIII. M ${ }^{\text {a }}$ Isabel Loring fallece en el transcurso de la elaboración de la obra.

${ }^{35}$ LORING, Ma. I., PÉREZ, S. Y FUENTES, P.: La Hispania tardorromana y visigoda. Siglos V-VIII..., p. 192.
} 
una nobleza fuerte que comandaba a sus milicias. La impronta privada y atomizada de los ejércitos al mando de los nobles y la merma del ejército público disminuyeron la capacidad regia para aglutinar en su entorno huestes numerosas para desafiar las coyunturas adversas, muchas veces propiciadas desde el seno de la nobleza goda. La dinámica social feudal de la aristocracia visigoda socavaba el dominio regio, haciéndolo vulnerable al apetito voraz nobiliario por los recursos fiscales.

Valverde Castro y Díaz Martínez son dos autores que han escrito bajo la influencia de Barbero y Vigil ${ }^{36}$, pero en los últimos años incorporaron nuevas perspectivas.

Valverde Castro sostiene que los reyes visigodos toledanos fueron sumando a sus responsabilidades militares las actividades propias del aparato administrativo, fiscal, legislativos y judicial. Este proceso de ampliación de poderes significó que los reyes se consolidasen en esas esferas de gobierno; a través de cada acto político el dominio regio aumentaba y se legitimaba. Sin embargo, los reyes encontraron límites reales ${ }^{37}$.

En sus escritos más tempranos, Valverde Castro y Díaz Martínez destacan las manifestaciones simbólicas como aspectos teóricos del dominio del monarca ${ }^{38}$. No obstante,

${ }^{36}$ DíAz MARTínez, P.C y VALVERDE CASTRO, Ma.R: "The theoretical strength and practical weakness of the visigothic monarchy of Toledo", en THEUWS, F. AND NELSON J.L., (eds.), Rituals of power, from Late Antiquity to the Early Middles Ages, Leiden; Boston; Köln: Brill, 2000. (The transformation of the Roman world; Vol. 8). p. 87. Elegimos centrarnos en este artículo y no en otros, pues tiene la virtud de condensar las ideas principales de estos dos autores sobre la dinámica política regia y brinda una solución al problema de la debilidad monárquica presente en la sociedad goda. Además, es un texto representativo de una época. Los escritos más nuevos poseen otros elementos, como veremos luego.

Otros textos de los autores de esta época: VALVERDE CASTRO, Ma.R: Ideología, simbolismo y ejercicio del poder real en la monarquía visigoda: un proceso de cambio, Salamanca: Universidad de Salamanca, 2000, VALVERDE CAStro, Ma.R::: "Leovigildo: Persecución religiosa y defensa de la unidad del reino", Iberia: Revista de la Antigüedad, 2, 1999, pp. 123-132. DíAZ MARTíNEZ, P.C.: "Rey y poder en la monarquía visigoda", Iberia, 1, 1998; "Sumisión voluntaria: estatus degradado e indiferencia de estatus en la Hispania visigoda (FV 32)", Studia historica. Historia antigua, 25, 2007, (Ejemplar dedicado a: Resistencia, sumisión e interiorización de la dependencia), pp.507-524; Hispania tardoantigua y visigoda, Madrid, Istmo, 2007; "El testamento de Vicente: Propietarios y dependientes en la Hispania del s. VI", en "Romanización" y "reconquista" en la Península Ibérica: nuevas perspectivas, 1998, pp.257-270.

${ }^{37}$ VALVERDE CASTRO, Ma . R.: Ideología, simbolismo y ejercicio del poder real en la monarquía visigoda: un proceso de cambio... pp. 225 y ss.

${ }^{38}$ Valverde Castro profundiza sobre las manifestaciones simbólicas por las cuales el poder de los reyes godos se materializó en sus dos planos: el teórico y el concreto. Su objetivo es develar la ideología política y el sustento teórico del poder regio. Argumenta que el asentamiento en Hispania se realizó mediante la ocupación, que tuvo impacto en el discurso ideológico, pues se consideró el derecho de conquista de estilo helénico como el principio legitimante de la monarquía. De esta manera, nace la idea de una corona completamente territorial y unificante 
al observar la documentación concluyen que los reyes procedían con limitaciones, ya que la fuerte nobleza terrateniente y la Iglesia no dudaban en desgastar al poder regio para favorecer sus propios intereses. Por lo tanto monarquía, Iglesia y nobleza competían por el control de las fuentes de riquezas, debilitando la estructura política. La lucha de facciones derivó en la contradicción del sistema político: en la teoría el rey era la máxima autoridad, en la práctica su soberanía estaba cercenada. Este antagonismo explícito entre la monarquía y la nobleza se tradujo, por ejemplo, en la incapacidad de establecer un sistema de sucesión real, y los continuos destronamientos serían el reflejo de la incompetencia de la institución regia para imponerse frente a la nobleza.

Al momento de explicar por qué la realeza no pudo hacerles frente a sus opositores apelan sin mayor exégesis al argumento de la feudalización de la sociedad visigoda tal como lo plantean Barbero y Vigil, postulando que la fuerza social y económica de la nobleza provenía de sus grandes dominios y los dependientes que los habitan ${ }^{39}$. Así, los argumentos provenientes de Barbero y Vigil son convertidos en axiomas.

En sus últimos trabajos, Díaz Martínez añade nuevos elementos de análisis a sus trabajos, sobre todo aquellos provenientes desde la arqueología ${ }^{40}$. Sobre nuestro tema en particular, este autor incorpora un punto de vista que pretende superar los argumentos que sostienen que la inestabilidad política fue causada por el antagonismo permanente entre la

del espacio peninsular. A este concepto de poder se le suma la imitatio imperii: múltiples símbolos y manifestaciones de origen romano fueron utilizados por los reyes para ostentar su poder frente al exterior (el rey godo y el emperador romano compartirían el mismo estatus), y también para fortalecerlo en el interior. Luego de este estudio la autora analiza el ejercicio concreto del poder en el cual llega a las mismas conclusiones que en el artículo reseñado en el cuerpo de este trabajo.

${ }^{39}$ DíAZ MARTíNEZ, P.C. y VALVERDE M.R: "The theoretical strength and practical weakness of the visgothic monarchy of Toledo"..., "The possession of great domains and of the people living in them provided the grandees of the kingdom with enough power to be in a position to face the monarchy in order to increase and defend their own interests." p. 86.

40 DíAz MARTíNEZ, P.C.: "El reino visigodo en vísperas del 711: sistema político y administración”, Zona arqueológica, 15, 2011; DíAZ MARTíNEZ, P. C \& I. MARTíN VISO, I.: "Una contabilidad esquiva: las pizarras numerales visigodas y el caso de El cortinal de San Juan (Salvatierra de Tormes, España)", en Entre el impuesto y la renta. Problemas de la fiscalidad tardoantigua y altomedieval, Bari: Edipuglia, 2011. DíAZ MARTíNEZ, P. C.: "Confiscations in the Visigothic Reign of Toledo: A Political Instrument", en PorenA, P. Y RIVIERE, Y. (eds): Expropiations et confiscations dans les royaumes barbares. Une approche régionale, Roma: École Française de Rome, 2012, pp. 93-112.

DíAz MARTíneZ, P.C.: "La dinámica del poder y la defensa del territorio: para una comprensión del fin del reino visigodo de Toledo". DíAz MARTíneZ, P. C. y POVEDA, P.: "Qui patrie excidium intulerunt. Hispania 711: explicaciones desesperadas para un colapso inesperado”, Reti Medievali, 17/2, 2016, 1-28. 
aristocracia y los reyes ${ }^{41}$. Opina que expuesto así es reducir un problema complejo a solo un enunciado. En sus últimos trabajos, afirma que los constantes enfrentamientos existentes entre la aristocracia y el rey se debieron a dos factores principales: 1) el control del patrimonio fiscal; 2) la aristocracia se veía a sí misma como un cuerpo unitario en el cual residía la legitimidad de gobernar ${ }^{42}$.

\section{Pervivencia de las estructuras estatales romanas en el reino visigodo de Toledo}

Un importante sector de la historiografía moderna, sobre todo a partir de 1970, se nutrió de los trabajos de principios del siglo XX de Dopsch $^{43}$ y Pirenne ${ }^{44}$. Bajo la influencia de este nuevo paradigma, que cuestionó fuertemente a la idea imperante del colapso del estado romano, surge la escuela historiográfica conocida como "Antigüedad Tardía". Los autores que se identifican en ella entienden al periodo comprendido entre los siglos III y IX en "términos de evolución lenta" 45 , al admitir la persistencia de las estructuras políticas y económicas de época imperial y negar la decadencia de la identidad cultural latina ${ }^{46}$.

\footnotetext{
${ }^{41}$ Asimismo, propone superar las explicaciones teleológicas sobre el final del reino visigodo. Un exponente de esto último: KING, P.D., Derecho y sociedad en el reino visigodo: "Pero es difícil pretender negar que el triunfo de los árabes se debió menos a su propia fuerza que a la debilidad de su víctima, y resulta también difícil no ver en la conquista de 711 algo así como un coup de grâce para un reino desmoralizado y en vías de desintegración empeñado en su propia destrucción", p. 41.

${ }^{42}$ Ver especialmente: DíAZ MARTíNEZ, P.C.: "La dinámica del poder y la defensa del territorio: para una comprensión del fin del reino visigodo de Toledo", pp. 170 y ss.

${ }^{43}$ Dentro de sus múltiples argumentos sobre el periodo, para la historiografía posterior será fundamental la tesis sobre el asentamiento de los bárbaros, y el funcionamiento de las estructuras estatales romanas en los reinos romanos-germánicos. DOPSCH, A.: Fundamentos económicos y sociales de la cultura europea (de César a Carlomagno), México: Fondo de Cultura Económica, 1986.

${ }^{44}$ Pirenne niega la decadencia económica del periodo, afirma que las estructuras socioeconómicas, sobre todo "La gran propiedad sigue llena de vigor" (p. 64). Casi en forma de premisa, enumera los elementos que considera dan muestra de una continuidad económica. PIRENNE, H.: Mahoma y Carlomagno, Buenos Aires: Editorial Heliasta, [1935], 2013, p. 62-99.

${ }^{45}$ SALRACH, J. M.: "Del estado romano a los reinos germánicos. En torno a las bases materiales del poder del estado en la Antigüedad tardía y la Alta Edad Media", De la Antigüedad al Medievo, siglos IV-VIII, Congreso de Estudios Medievales, Madrid: Fundación Sánchez Albornoz, 1993, p 97.

${ }^{46}$ Trasladándonos al ámbito ibérico, y para los siglos que nos conciernen, por ejemplo, autores como Fontaine, Díaz y Díaz, Hillagarth, consideran evidente que en el reino de Toledo continuaron los comportamientos de tipo romano, sobre todo en los ámbitos culturales y religiosos. FONTAINE, J.: Isidoro de Sevilla: Génesis y originalidad de la cultura hispánica en tiempo de los visigodos, Madrid: Ediciones Encuentro, 2002. HILlagarth, J: "Historiography un Visigothic Spain”, Settimania Stud Sull' Alto Medievo XVII, Spoleto, 1970. Hillagarth, J.: "Coins and Chronicles: Propaganda in Sixth-Century Spain and the Byzantine Background",
} 
Aun actualmente, esta metanarrativa inspira planteos sobre la prolongación de las estructuras socioeconómicas romanas en la Península Ibérica, por tal motivo repasamos brevemente las tesis más relevantes.

Los fiscalistas — Walter Goffart y Jean Durliat como los representantes más influyentes - acuerdan en que el derecho público, las instituciones, el régimen de propiedad y las estructuras estatales — máxime el sistema fiscal romano- no sufrieron alteraciones considerables luego de la entrada de los bárbaros. Estos asentados en tierras romanas se ajustaron a las exigencias del entorno, mientras que los romanos adaptaron las normativas de acuerdo con las urgencias de la época. Como aporte propio, Goffart sostiene que los bárbaros afincados en el Imperio recibieron una "titularidad fiscal y su producto" ${ }^{4}$, suceso que no perturbaría los derechos de propiedad romanos ni el pago de los impuestos, por lo menos en los primeros tiempos de efectuado el reparto. Por su parte, Durliat ${ }^{48}$, en su estudio centrado en la Italia del Bajo Imperio y el corazón franco, argumenta que las invasiones no erradicaron ni alteraron de forma sustancial las estructuras fiscales romanas. Al contrario desde Diocleciano (en torno al año 284) hasta la caída de los carolingios se originó una descentralización de la recaudación de los impuestos, pero no su declinación. Según este autor, el possessor recorría las jurisdicciones fiscales (possessio, fundus), de acuerdo con los registros públicos, recaudando el impuesto (el censum) de los contribuyentes (los servi, accola, ingenui, liberti, mancipia y los colonos; estos últimos serían propietarios $-\mathrm{y}$ no arrendatarios -). Los críticos de esta tesis señalan ${ }^{49}$ como problema sustancial el valor denotativo dado a los vocablos latinos en la lectura de las fuentes, como por ejemplo la consideración de los servi como contribuyentes, que niega el significado clásico de sujetos atados a algún tipo de servidumbre.

Historia: Zeitschrift für Alte Geschichte, 1966, pp. 483-508. DíAZ Y DíAZ, M.C.: De Isidoro al siglo XI, Barcelona: El Albir Ediciones S.A, 1976.

${ }^{47}$ Goffart, W.: "Los bárbaros en la Antigüedad Tardía y su instalación en Occidente". En: LitTLE, L.; RoSENWEIN, W., (eds.).: La Edad Media a debate, Madrid: Akal, 2003. p. 79

${ }^{48}$ DURLIAT, J.: Les finances publiques de Dioclétien aux Carolingiens (284-888), Sigmaringe, Beihefte der Francia XXI, 1990.

${ }^{49}$ WiCKHAM, C.: "La caída de Roma no tendrá lugar", en LitTLe, L. K y Rosenwein, B.H. (ed.): La Edad Media a debate, Madrid: Akal, 2003, pp. 80-101. WicKHAM, C.: Una historia nueva de la Alta Edad Media, Europa y el mundo mediterráneo, 400-800, Barcelona: Crítica, 2008, p. 152. HALSALL, G.: Las migraciones bárbaras y el occidente romano, 376-568, Valencia: Univeritat de Valéncia, 2012, pp. 441 y ss. 
Influenciada por estos modelos interpretativos, C. Martin elabora un modelo que presenta al reino visigodo como un estado fuerte y centralizado ${ }^{50}$. Examinando la política regia sobre el espacio, esta autora describe el proceso por el cual la corona sedujo a los agentes locales a través de la delegación de competencias administrativas, con el fin de transformarlos en representantes del poder público alineándolos a su potestad. Si en los escritos tradicionales la encomienda de facultades gubernativas se veía como una flaqueza de los reyes, para ella es un elemento que estaría indicando un fortalecimiento del vértice del poder. Del mismo modo, observa que ciertas reformas ejecutadas a mediados del siglo VII por los monarcas (como la emisión monetaria, la revisión y nuevas ediciones de los códigos legislativos, la invención de los nuevos cargos de $d u x$ y thiufadus, la promoción de Toledo como capital del reino y centro, etc.) fueron parte del reforzamiento del dominio central, renovaron y redimensionaron las prácticas institucionales romanas (que no fueron descartadas sino que sirvieron de basamento) para crear un nuevo estado ${ }^{51}$. Esta vitalidad estatal se retroalimentó con proyecciones ideológicas y un fuerte sentido de raigambre sobre el territorio. Dentro de este esquema la institución monárquica ha sido la figura dominante de las fuerzas políticas. Una de las claves de la tesis de C. Martin radica en comprender las negociaciones que estableció el centro con las elites regionales.

En relación con la inestabilidad política de los reyes, C. Martin analiza las veintiuna revueltas acaecidas contra los soberanos godos entre los años 550 y 711 con el mero objetivo de establecer si las mismas tuvieron aspiraciones separatistas, es decir, si hubo poderes locales pujantes capaces de doblegar a la realeza en función de su autonomía. Ante esta hipótesis, concluye que los protagonistas de las sediciones tuvieron como fin ocupar el trono en la ciudad de Toledo y no quebrantar al reino en regiones independientes. La autora descarta el análisis estructural de las frecuentes revueltas contra los reyes, que podría contradecir la idea de un estado fuerte encabezado por monarcas enérgicos y emprendedores.

\footnotetext{
${ }^{50}$ MARTIN, C.: La géographie du pouvoir dans l'Espagne visigothique....

${ }^{51}$."L'Hispanie visigothique ne fut pas seulement un conservatoire de la romanité, un musée où les bâtisseurs des édifices politiques ultériurs allaient pouvoir acquérir des matèriuax impèriaux propres à les enraciner dans un passé brillant, mais revolú. Le royaume visigothique fut bien plus que cela. Flèche lancée vers l'avenir, il sut élaborer, dans un monde nouveau, des structures et des idées nouvelles". MARTIN, C.: La géographie du pouvoir dans l'Espagne visigothique..., p. 371.
} 
En una línea similar, Damián Fernández plantea sus investigaciones. Sobre el tema que nos preocupa, el autor propone que en el reino visigodo las relaciones estatales resurgieron. Destaca que durante el siglo VI y VII tuvo lugar un proceso de unificación del reino y de edificación del estado, con varios grados de éxito. La aristocracia estableció un gobierno en Toledo desde donde impartía justicia y administraba los asuntos fiscales. El dominio regio contó con el beneplácito de la Iglesia, dotándolo de un elaborado aparato ceremonial legitimante. En estas circunstancias, las revueltas aristocráticas nunca tuvieron como finalidad objetar al proyecto estatal ${ }^{52}$. Por otro lado, valiéndose de las evidencias que la arqueología ha proporcionado, plantea que luego del siglo V la aristocracia terrateniente mantuvo su posición dominante en las zonas rurales, prueba de ello sería la capacidad de direccionar recursos a la construcción de iglesias rurales y monasterios ${ }^{53}$. La lectura que realiza de la evidencia material coincide con la visión de Ariño que presentamos en el capítulo dos, mas confronta con otra línea historiográfica que reseñaremos a continuación.

\section{La Península Ibérica desde nuevas perspectivas. Arqueología y etnogénesis}

En los últimos veinte años el periodo temprano medieval europeo es abordado a través de categorías propias, como anuncia Rosamond McKitterick

"It is a mistake to see the kingdoms of early medieval Europe either as a messy version of the late Roman social and political patterns or as rudimentary versions of that which existed in Europe from the eleventh century onwards ${ }^{\text {,54 }}$.

Los estudios que siguen este horizonte apuestan por comprender al periodo en una totalidad nueva, tanto espacial (Europa es analizada en un escenario en conjunto,

\footnotetext{
52 FERNÁNDEZ, D.: Aristocrats and Statehood in Western Iberia, 300-600 C.E., Philadelphia: University of Pennylvania Press, 2017, pp. 8 y ss.

${ }^{53}$ FERNÁNDEZ, D.: "Desigualdad económica, propiedad rural y cultura material en la Antigüedad Tardía. El caso de la Península Ibérica (siglos IV-VII)", CAmpagno, M., Gallego, J. GarCía MaC GaW, C.G.: Capital, deuda y desigualdad. Distribuciones de la riqueza en el Mediterráneo antiguo, Buenos Aires: Miño y Dávila, 2017, p. 173-193. FERNÁNDEZ, D.: "Property, Social Status, and Church Building in Visigothic Iberia", en Journal of Late Antiquity, 9, 2, Fall 2016, pp. 512-541, especialmente las pp. 519-524.

${ }^{54}$ MCKitTericK, R.: "Politics", en The Early Middle Ages, Europe 400-1000, (ed. Rosamond McKitterick), New York: Oxford University Press, 2001, p. 25.
} 
franqueando los regionalismos y sus particularidades) como socioeconómica (las bases materiales y las estructuras políticas poseen su propia lógica de funcionamiento). Los descubrimientos arqueológicos han sido claves para esta nueva visión, así como la revisión crítica (e incluso filológica) de los documentos escritos. Además, se agrega un elemento de análisis fundamental para un periodo lleno de transiciones: la conformación de las identidades, es decir, el proceso de etnogénesis. Los nuevos esquemas interpretativos generales sobre este periodo histórico han alentado a que los paradigmas tradicionales que explicaban la sociedad visigoda sean tensionados, y hasta interpelados.

La obra que impulsó a parte de la historiografía a romper con la tesis de la decadencia del Imperio Romano y los esquemas explicativos de tipo tardoantiguo sobre el periodo ha sido el libro publicado por Wickham en el año $2005^{55}$.

Este autor realiza un análisis de historia comparada económico-social de Europa Occidental y el ámbito mediterráneo entre el 400 y el 800. Su obra recorre múltiples espacios geográficos: Inglaterra, Gales, Irlanda, Dinamarca, Galia\Francia, España, Italia, norte de África, área central de Bizancio (Anatolia y el Egeo), Siria y Palestina, y Egipto. Como resultado de su investigación establece bases generales para el periodo: la simplificación de las estructuras fiscales; las contingencias regionales y el fin de la unidad romana; la debilidad relativa de la aristocracia que media sólo sobre sus convecinos (excluyendo el Norte de Francia y Levante); el declive del intercambio comercial y un salto identitario-cultural de la aristocracia. Como consecuencia del proceso de empobrecimiento de la aristocracia en términos de dominio político y material surgió una lógica campesina autónoma. Con el fin de comprender su funcionamiento el autor propone el concepto de modo de producción campesino, que en ciertas partes de Europa (el norte insular y otros enclaves continentales) se materializó en una formación social propia.

El concepto de modo de producción campesino es objeto de estudio del siguiente capítulo. En el presente sólo nos concentraremos en las consideraciones del autor sobre la

\footnotetext{
55 Wickham, C.: Framing the Early Middle Ages. Europe and the Mediterranean. 400-800. Oxford, 2005. Versión en español: Una historia nueva de la Alta Edad Media, Europa y el mundo mediterráneo... Esta obra sintetiza y expande las tesis planteadas con anterioridad por el autor para la Alta Edad Media Europea. Sin embargo, el carácter monumental del libro y, sobre todo, el método comparativo empleado lograron que su visión del periodo sea considerada por los especialistas de todas las regiones y etapas abordadas.
} 
región de la España visigoda, la cual no expresaría, según su opinión, los parámetros de sociedades campesinas predominantes en otras regiones.

A través del estudio de la documentación escrita y los restos materiales, Wickham se pronuncia sobre tres aspectos fundamentales de la sociedad visigoda: la organización estatal, la riqueza de la aristocracia y el régimen de tierras y el sistema de intercambios.

En relación al estado, el autor plantea que, luego de la fragmentación espacial del siglo V producto de la crisis secular, y a partir de la empresa fundacional de Leovigildo mediante la conquista de las zonas autónomas (en la década del 570), el reino fue lo suficientemente fuerte ${ }^{56}$ como para centralizar una maquinaria legal (la celebración periódica de los Concilios toledanos, las promulgaciones y revisiones de los códigos legales) y ceremonial (los ritos manifestantes de ideología) en torno a la capital del reino, la ciudad de Toledo; además de vincular a las aristocracias locales con la corte regia ${ }^{57}$. Si bien acepta que la fisonomía geográfica hispana dificulta la concreción de un espacio orgánico, califica al afán de centralización de fines del siglo sexto como un éxito tan contundente que toda la estructura sobrevivió a los vaivenes políticos contra los reyes de la primera mitad del siglo VII, logrando para fines de siglo la consolidación de la monarquía y de toda la estructura institucional. Asume que el estado mantuvo vigente la recaudación de impuestos, no sin dificultades, con el fin de financiar al Oficio Palatino y las ceremonias toledanas. Extendiendo a los visigodos el razonamiento sobre el caso vándalo ${ }^{58}$, plantea que la práctica impositiva no fue sustancial ya que el ejército tuvo otra forma de financiarse, pues estuvo compuesto mayoritariamente por hombres libres, que formaron clientelas privadas fieles a un patrón que no necesariamente era el monarca (pudo ser un conde, un duque o un privado), y en menor medida por los no libres que seguían a sus patronos o $\operatorname{amos}^{59}$, los cuales recibieron como pago por sus servicios porciones de tierra. Wickham se muestra complaciente con los argumentos esgrimidos por Barbero y Vigil sobre los vínculos de fidelidad, las políticas de

\footnotetext{
56 "En el Occidente posromano, la presencia de los visigodos en España sobresale por una particularidad: su estado no fue debilitándose con el tiempo, sino haciéndose más fuerte", WICKHAM, C.: Una historia nueva de la Alta Edad Media..., p. 162.

${ }^{57}$ Ibidem, p.163 y ss.

${ }^{58}$ Según el autor, los vándalos llevaron al mínimo la recaudación de impuestos ya que la financiación del ejército se realizó a través de la entrega de tierras. Ibidem, p. 157 y ss.

59. Ibidem, p. 168 y ss.
} 
donación de tierras y la conclusión esbozada sobre el traslado de las obligaciones públicas al ámbito de las dependencias personales; de esta manera manifiesta que

"Los visigodos habían comenzado a adentrarse en la $<$ sociedad feudal $>$ de Marc Bloch, y habían hecho de la política de posesión de tierras el elemento crucial de la construcción de las relaciones políticas" ${ }^{\circ}$.

A través de la lectura de la documentación escrita (las Vidas de los santos, los escritos en pizarras, los pocos testamentos, los códigos legales), Wickham alega la existencia de una aristocracia rica, próspera, relativamente estable y propietaria de grandes posesiones de tierras explotadas al modo tardorromano; estas élites circunscribieron su poder socioeconómico a escala micro regional, mientras que sólo los vínculos políticos se extendieron hacia la capital del reino.

Para el análisis de la red de intercambios el autor estudia distintas regiones de la Península Ibérica para dar cuenta de las diferencias existentes entre cada una de ellas. Observemos con más detalle.

En la Andalucía interior observa cohesión espacial, una relativa concentración de la riqueza y centros urbanos. La cerámica posee características posromanas y es de buena calidad. Mérida, Córdoba y Sevilla constituyeron los principales núcleos citadinos donde se encuentra una compleja pauta de intercambio, que se reprodujo en sus ámbitos rurales, si bien también se advierte en la región una cerámica más simple de origen doméstico.

El sureste, luego de la incorporación de la provincia bizantina al reino de Toledo, sufrió una caída de la demanda y una simplificación de los sitios rurales y urbanos; según el autor, posiblemente como consecuencia de su exclusión de la red comercial mediterránea.

Por su parte, la zona nororiental (Cataluña, Valencia y el valle del Ebro) proporciona una imagen de relativa continuidad urbana y de algunas villas. Los asentamientos rurales manifiestan una forma aldeana. Sin embargo, hacia el octavo siglo las estructuras de intercambio se debilitaron; la aristocracia conservó su posición de prestigio si bien su número disminuyó congregándose en los centros urbanos.

\footnotetext{
${ }^{60}$ Ibidem, p. 170. Es interesante resaltar que para afirmar la frase citada Wickham se apoya en los escritos de Sánchez Albornoz, García Moreno y Barbero y Vigil. Véase nota número 111 del capítulo tercero, p. 1203.
} 
En el siglo VI, en la zona sur de la Galia la producción de cerámica fue simple, aunque correspondió a una compleja red de intercambios relacionada con una aristocracia rica asentada en vastas tierras; es altamente probable que su marco de acción hubiera estado restringido al área regional.

Por último, la Meseta presenta una urbanización desigual, fincas muy ricas y zonas con campesinos propietarios. La ciudad de Toledo constituyó un polo de atracción, por lo menos para el área rural lindante; la cerámica posee un estilo posromano, aunque limitada a la comarca, lo que demuestra una especialización y una demanda relativamente significativa. Este espacio regional se erigió en una suerte de Königslandschaft, es decir, el espacio donde el rey ejercía una dominación hegemónica sobre la población asfixiándola bajo una dependencia política y económica. Wickham no deja de reconocer que en los territorios montañosos mesetarios, alejados de la periferia toledana, existían estructuras sociales mucho más laxas.

Los datos relevados en el análisis de los intercambios comerciales, principalmente desde la lectura de las piezas arqueológicas (como elemento clave la cerámica) le presentan al autor una disparidad en relación a los datos de las fuentes escritas: mientras que estas últimas revelan una aristocracia económicamente consolidada y un estado centralizado encabezado por enérgicos monarcas, los restos materiales de las distintas regiones de la Península, en líneas generales, pero contando con algunas disimilitudes, presentan una simplificación de la economía y de la demanda y los intercambios fueron marcadamente locales. Esto indica la casi nula articulación de las regiones del reino y, como consecuencia, la escasa vinculación socioeconómica de las elites locales con el poder central, que en última instancia se traduce en una disgregación estatal y una élite débil. Para salvar esta contradicción aparente, Wickham plantea que ha sido la misma pobreza aristocrática la que le facilitó al rey el dominio sobre este sector, al ofrecer cuantiosos beneficios salidos de sus ricas arcas. Fue en el ámbito político donde confluyeron las fuerzas aristocráticas regionales dando cohesión al reino.

Es interesante señalar que, como C. Martín, Wickham afirma que los reyes visigodos poseían una fortaleza institucional que los habilitaba para cohesionar políticamente al reino. Además, considera que a partir de mediados del siglo VII los conflictos en torno a la sucesión regia, si bien implican tensión, no estallaron en situaciones de violencia incontrolables. 
En el resumen presentado sobre los argumentos de Wickham están presentes de forma breve (inclusive tangencial, entendible por la finalidad comparativa de la obra) los problemas que actualmente se desarrollan en las investigaciones que se ocupan del espacio hispanovisigodo. No está de más decir que este libro se convirtió en un horizonte historiográfico, imposible de ignorar y/o de citar, e incluso es el que impulsó las nuevas perspectivas sobre el periodo.

Los interrogantes, en relación con nuestro objeto de estudio primario, que abren los historiadores contemporáneos que se sirven de la arqueología y de la crítica literaria versan sobre, principalmente, la naturaleza del dominio aristocrático y las identidades políticas. Las estructuras económicas, la fisonomía del paisaje rural y la revisión de los textos legales componen otro conjunto de problemas que son también atendidos por muchos expertos ${ }^{61}$.

Conceptos como regionalización, diálogo, negociación, élites locales, proliferan en las investigaciones recientes ${ }^{62}$. La relación entre las aristocracias de alcance regional y los reyes de Toledo es analizada a través de las nociones de jerarquía y negociación ${ }^{63}$. En ese sentido, las aristocracias locales no son entendidas como "periféricas" en relación con un

\footnotetext{
${ }^{61}$ En el capítulo dos damos cuenta de los distintos paradigmas explicativos existentes para comprender las economías de las aldeas y su vinculación con la clase aristocrática.

${ }^{62}$ Castellanos y Martín Viso sostienen que "We emphasize that, in our opinion, the dialogue between central power and the local scene is one of the keys to a precise understanding of the articulation of political power." en: CASTEllanos, S., y Viso, I. M.: "The local articulation of central power in the north of the Iberian Peninsula (500-1000)", Early Medieval Europe, 2005, 13(1), pp. 1-42, p. 2. Otros autores que aceptan y comparten esta visión: SÁNCHEZ PARDO, J. C.: "Sobre las bases económicas de las aristocracias en la Gallaecia suevo-visigoda (ca. 530-650 d.C). Comercio, minería y articulación fiscal", Anuario de Estudios Medievales, vol. 44, 2, 2014. WooD, J.: The Politics of Identity in Visigothic Spain: religion and power in the histories of Isidor of Seville, Leiden: Brill, 2012. MARTíN VISO, I. ET AL.: "La formación de un nuevo paisaje en el centro de la península ibérica en el periodo posromano: el yacimiento de La Genestosa (Casillas de Flores, Salamanca)", en Archivo Español de Arqueología, vol. 90, 2017. Desde un punto de vista arqueológico: QuIRÓs CASTILlO, J. A.: "Early medieval landscapes in northwestern Spain: local powers and communities, fifth-tenth centuries", Early Medieval Europe, 2011a, 19.3, pp. 285-311. Quirós CASTILLO, J. A.: "Defensive sites of the Early Middle Ages in North-West Spain", BAKER, J., BROOKES S. Y REYNOLDS, A. (eds.): Landscapes of Defence in Early Medieval Europe, Turnhout, 2103, pp. 301-339. VIGIL-ESCALERA, A.: Los primeros paisajes altomedievales en el interior de Hispania. Registros campesinos del siglo quinto d.C., Bilbao, 2015.

${ }^{63}$ Estos términos son empleados para el análisis histórico de la Alta Edad Media desde la incorporación de la teoría del don a partir de 1950. En una importante obra colectiva que tiene como eje vertebrador el intercambio de regalos, esto último se lo comprende como una negociación, un proceso de duración indefinida. ALGAZI, G.; Groebner, V.; JusSEN, B. (ed.): Negotiating the gift: pre-modern figurations of Exchange, Alemania: Vandenhoeck \& Ruprecht, 2003, en especial las pp. 13 y ss.
} 
"centro"; la estricta categoría de oposición e intereses contrapuestos se matizan. Por ejemplo, Jamie Wood afirma que

“(...) the extent of the Visigoths' hold over Spain was variable as regional and local groups often asserted their independence from the authority of the royal and ecclesiastical centre at Toledo" $" 64$

Castellanos y Martín Viso plantean que en el reino de Toledo el diálogo entre el poder regio y las aristocracias locales debe ser comprendido en términos de la búsqueda de oportunidades, beneficios e incluso de límites y rupturas. Esta relación dinámica llevaría al centro a derramarse de forma no uniforme ${ }^{65}$. Martín Viso considera que la hegemonía política que obtuvo Leovigildo a través de su expansión militar (fines del siglo VI), y que heredó posteriormente el reino visigodo católico, se debió en parte al reconocimiento de los núcleos menores en manos de los poderes locales, es decir, a cambio de aceptar la autoridad regia les permitieron conservar los mecanismos de control de la organización interna local ${ }^{66}$.

Los aportes arqueológicos se convierten en elementos decisivos para la comprensión de las relaciones de dominio en estas nuevas claves interpretativas. Principalmente para las áreas donde las pruebas escritas escasean. En el capítulo dos nos detenemos largamente en las propuestas que integran elementos de la cultura material en sus investigaciones.

Por otro lado, los postulados sobre la etnogénesis formulados originalmente por la escuela de Viena ${ }^{67}$ permitieron cuestionar dos grandes problemas que dominaron gran parte de la historiografía del siglo XX: el enfrentamiento, por un lado, entre romanos y bárbaros, y, por el otro, entre católicos y arrianos.

La idea de Wolfram sobre el carácter poliétnico de los pueblos bárbaros estableció un nuevo enfoque sobre el asentamiento de estos grupos en el Imperio Romano; el concepto de integración suavizó la visión de la migración brusca, violenta. La etnogénesis acompañó a la

\footnotetext{
${ }^{64}$ Wood, J.: "Borders, Centres and Peripheries in late Roman and Visigothic Iberia", International Journal of Regional and Local History, 2015, 10:1, 1-17, pp. 8 y 9.

${ }^{65}$ Castellanos, S., y VISO, I. M.: "The local articulation of central power in the north of the Iberian Peninsula (500-1000), en especial p. 42

${ }^{66}$ MARTín VISO, I.: “Organización campesina y dominios políticos en la cuenca del Duero altomedieval”, Sociedades Precapitalistas, 7 (2), 2018.

${ }^{67}$ Sobre los alcances de esta teoría ver la p. 227 de esta tesis donde desarrollamos los principales puntos.
} 
escuela que se nutría de la tesis de Pirenne, quien postuló una entrada progresiva, lenta, de los bárbaros en territorio romano, destronando la vieja idea del "asesinato" y decadencia del Imperio. En la actualidad, esta visión se transformó, y se advierte que el quiebre de la unidad se desencadenó en el siglo $\mathrm{V}$, dando lugar a un proceso de reconfiguración de las relaciones socioeconómicas. La idea de etnogénesis perdura en los estudios por su capacidad explicativa sobre los cambios identitarios llevados a cabo por las elites romanas y germanas en los siglos posteriores al siglo $\mathrm{V}$.

A luz de esta teoría, etnicidad y religión conformaron marcas fundamentales de pertenencias. Desde la interrupción de la Escuela de Viena, la etnicidad no se relaciona con los vínculos de sangre, sino que es considerada un estatus adscripto, autopercibido. La identidad (religiosa y/o étnica) es una identidad política, flexible y manipulable, utilizada por los sujetos poderosos como un instrumento.

Por otro lado, las nuevas críticas sobre los documentos permitieron revalorizarlos. La sistematización, catalogación y estudio sobre las monedas y cecas visigodas realizadas por Pliego Vázquez aportan elementos fundamentales para el estudio de múltiples dimensiones analíticas $^{68}$. La masa monetaria brinda una información tanto de tipo económica como política. Las mismas cualidades tienen las pizarras, estudiadas y editadas por Velázquez Soriano $^{69}$. Asimismo, destacamos la edición de las cartas de Braulio de Zaragoza ${ }^{70}$ y las Vitas Sanctorum Patrum Emeretensium ${ }^{71}$; también es notable el análisis sobre la producción de Isidoro de Sevilla ${ }^{72}$. Por último, una obra ineludible y de gran valor sobre los intelectuales visigodos es la compilación editada por Codoñer ${ }^{73}$. Los autores realizan exhaustivos trabajos que orientan el análisis documental, permitiendo comprender mejor el contexto de elaboración.

\footnotetext{
${ }^{68}$ Pliego VÁzQuez, R.: La moneda visigoda: Historia monetaria del reino visigodo de Toledo (c. 569-711), Sevilla: Secretariado de Publicaciones, Universidad de Sevilla, 2009.

69 VelázQuez SoRiano, I.: Las pizarras visigodas: edición crítica y estudio, Universidad de Murcia, Secretariado de Publicaciones, 1989.

${ }^{70}$ Miguel Franco, R.: Braulio de Zaragoza. Epistolas, Akal, 2015.

${ }^{71}$ Vidas de los Santos Padres de Mérida. Introducción, traducción y notas de Isabel Velázquez, Editorial Trota, Madrid, 2008.

${ }^{72}$ WoOD, J.: The Politics of Identity in Visigothic Spain: religion and power in the histories of Isidor of Seville. Koon, S. Y Wood, J.: “The Chronica Maiora of Isidore of Seville", e-Spania[En ligne], 6, diciembre 2008.

${ }^{73}$ CODOÑER, C. (coord.).: La Hispania visigótica y mozárabe: dos épocas en su literatura, Salamanca: Ediciones Universidad de Salamanca, 2010.
} 
Las leyes visigodas y los Concilios también son sometidos a debates y reflexiones. El fruto de las revisiones permite sortear la rígida visión sobre la incapacidad de estos documentos de transmitir datos sobre la sociedad visigoda; si bien el carácter normativo reduce las posibilidades de exploración, el estudio intensivo sobre la época, contexto e intenciones de producción permiten volver a estas fuentes con otras preguntas.

El tratamiento historiográfico realizado sobre el problema que anima a esta tesis da cuenta de varias cuestiones.

El hecho de que la historiografía por fuera de España, durante una gran fracción del siglo XX, le brinde un espacio reducido al estudio de los visigodos es (en parte) consecuencia del fenómeno de las tradiciones historiográficas o visiones nacionales, que se preocupan por buscar soluciones a los problemas peculiares de sus cunas a partir de la investigación en torno a los primeros siglos de la Edad Media. Como resultado el análisis del reino visigodo de Toledo tuvo una entrada demorada en el mundo académico internacional. Los libros de Thompson y King fueron de las primeras obras en inglés sobre el reino de Toledo, dato que ejemplifica lo dicho. El sesgo nacionalista comienza a romperse, la idea de la "particularidad" visigoda $^{74}$ (es decir, el feudalismo visigodo) también. Las colaboraciones internacionales, así como las publicaciones en revistas no españolas, impulsan la comprensión del reino visigodo en los mismos términos que son entendidos sus vecinos contemporáneos.

Actualmente, las líneas de investigación abiertas se nutren de la bibliografía internacional, a la vez que aportan nuevos elementos de análisis para todo el periodo y para todo el espacio europeo.

La renovación historiográfica del periodo y los aportes de la arqueología impulsan el planteo de nuevas hipótesis de trabajo. Sin embargo, detectamos que el problema de la dinámica política de los reyes visigodos no es un problema privilegiado o pensado desde otras perspectivas. Considerado como parte de la historia política acontecimental, o entendido como fenómeno derivado de un sistema feudal o protofeudal, la historia política sufrió un aislamiento en las investigaciones. De hecho, los trabajos que casi por obligación remiten a los procesos políticos repiten las fórmulas tradicionales. Este cuadro de situación

\footnotetext{
${ }^{74}$ Collins ha sido muy crítico con este concepto y con los seguidores de este. ColLins, R.: La España Visigoda 409-711, pp. XIII y ss.
} 
nos impulsa a tratar el problema de la dinámica de los reyes godos desde un enfoque sistémico.

\section{CAPÍtulo 2}

\section{EL REINO VISIGODO DE TOLEDO, UNA FORMACIÓN SOCIAL DE BASE CAMPESINA}

En la primera parte de este capítulo analizaremos el estudio del concepto modo de producción campesino con el fin de precisar el marco general de esta investigación. En la segunda parte describiremos el medio rural visigodo ibérico a partir de los hallazgos 
arqueológicos y de los documentos escritos. El desglose del modo campesino y las pruebas empíricas permitirán caracterizar a la sociedad visigoda como una formación social, con su propia lógica de funcionamiento, evitando así recurrir a herramientas teóricas propias de la Antigüedad o del feudalismo para explicar las relaciones sociales del periodo. Lo antedicho no equivale a negar a otros tipos de relaciones sociales, como el esclavismo o el colonato; al contrario, argumentamos que las relaciones sociales regidas bajo la lógica de la reciprocidad propia del modo campesino dominaron a la formación social visigoda.

Nota sobre el concepto de formación social

A lo largo de la tesis utilizaremos los términos reino visigodo o sociedad visigoda en el sentido de formación social. El concepto de formación social, entendido como la combinación de diferentes sistemas bajo la lógica de uno que predomina, posibilita la comprensión de las múltiples situaciones por las que el reino atravesó. Este concepto ha sido discutido largamente por la tradición marxista ${ }^{75}$; se destacan los análisis de Sereni y Glucksmann sobre las enunciaciones de Lenin sobre el uso de la noción de formación social. Sereni indica que:

“esta categoría expresa unidad (y, agreguemos nosotros, la totalidad) de las diferentes esferas: económica, social, política y cultural de la vida de una sociedad; y la expresa, por lo demás, en la continuidad y al mismo tiempo en la discontinuidad de su desarrollo histórico." ${ }^{\circ 6}$

Glucksmann subraya el carácter dinámico del modelo leninista de la formación social (hecho que está íntimamente ligado al momento político de su elaboración). El principal atributo de la conceptualización de Lenin es que acepta la convivencia de distintos modos de

\footnotetext{
75 Luporini, C. Y Sereni, E. (eds.): El concepto de “formación social”, México: Cuadernos de Pasado y Presente 39, 1973. Un recuento del debate y aportes al mismo en: DA GRACA, L. Y ZiGARELLI, A. (eds.): "Introduction to Studies on Pre-Capitalist Modes of Production: Debates, Controversies and Lines of Argument", en DA GRACA, L. Y ZigARELl, A. (eds.): Studies on Pre-Capitalist Modes of Production, Historical Materialism Book Series, 97, Leiden: Brill, 2015.

${ }^{76}$ SERENI, E.: "La categoría de <formación económico- social>”, en LUPORINI, C. Y SERENI, E., E. (eds.): El concepto de "formación social”, Cuadernos de Pasado y Presente 39, México, 1973, p.69. Destacado en el orignial.
} 
producción; los elementos de uno no existen aislados dentro del otro, sino que operan creando situaciones simbióticas. Además, las nuevas formas se insertan en las antiguas "y les dan un contenido nuevo" ${ }^{\text {"77 }}$. La dominancia de un modo sobre otro dentro de la formación social concreta es también una característica central. Glucksmann no duda en considerar que esta conceptualización de la formación social constituye a la vez un modelo de la transición, dado que los elementos sociales y económicos que conviven lo hacen en una permanente lucha por imponerse $^{78}$. Notemos que esta conceptualización adoptada por Glucksmann (y también por otros como Luporini y Fioravanti) responde a las elaboraciones de Althusser y Balibar, y fue adoptada desde la sociología histórica por análisis hiperteóricos, como los de Hindess y Hirst $^{79}$, y por análisis históricos concretos como el de Chris Wickham ${ }^{80}$.

El uso del concepto de formación social permitirá entender las diferencias situacionales del reino visigodo.

\section{1 .}

\section{El modo campesino: modo dominante de la formación social del reino visigodo de Toledo}

El modo de producción campesino definido por Wickham tiene un alto potencial explicativo para entender al periodo altomedieval, incluso mayor de lo que el propio Wickham estima. Este concepto otorga un marco analítico que explica las relaciones sociales y de poder en un contexto de debilidad de la clase dominante, a pesar de las limitaciones que se le señalan.

\footnotetext{
${ }^{77}$ GluCKSMANN, C.: "Modo de producción, formación económica y social, teoría de la transición a propósito de Lenin", en LUPORINI, C. Y SERENI, E. (eds.): El concepto de "formación social", México: Cuadernos de Pasado y Presente 39, 1973, p. 171.

${ }^{78}$ Ibidem, p. 174.

${ }^{79}$ HINDESS, B. Y HIRST, P.: Los modos de producción precapitalistas, Barcelona: Ediciones Península, 1979.

${ }^{80}$ WiCKHAM, C.: "La otra transición: del mundo antiguo al feudalismo",Studia Historica. $H^{a}$ Medieval, $\mathrm{n}^{\circ} 7$, 1989, pp. 7-35. Este artículo es inspirador para el medievalista consagrado a la historia social, porque sin renunciar a las perspectivas amplias y al largo plazo, se consagra a una problemática concreta vista en las fuentes con un arsenal de categorías interpretativas. No está demás indicar que el mencionado ensayo de Wickham es temáticamente próximo a esta monografía
} 
En el 2005 Wickham retoma el problema sobre las sociedades de base campesina planteado con anterioridad ${ }^{81}$. Volviendo sobre sus fundamentos, enriquece el concepto de sociedad de base campesina con conclusiones parciales o totales extraídas de estudios antropológicos clásicos, dando origen a una nueva categoría de análisis. Si en un primer momento el concepto se construye con base en una sociedad "real" (la Islandia de los siglos $\mathrm{X}$ y XI), el segundo lo es a partir de elementos de distintas sociedades y tiempos también reales, pero que se transforman en abstracciones teóricas para aprehender la realidad. A partir de este procedimiento las últimas formulaciones obtuvieron el estatus de modo de producción.

Los dos ejes que constituyen un modo de producción, es decir, las fuerzas productivas y las relaciones sociales entre los miembros de la comunidad ${ }^{82}$, se encuentran en los elementos centrales del modo de producción campesino que a continuación explicaremos ${ }^{83}$.

Las unidades domésticas compuestas por familias nucleares trabajan individualmente su parcela de tierra. La explotación individual es una característica notoria, al igual que en el modo de producción germánico ${ }^{84}$; a pesar de que Wickham no jerarquiza la condición de propietarios individuales de los productores directos, destaca su autonomía económica y la apropiación de los recursos de forma individual como un rasgo central ${ }^{85}$.

Wickham se inspira en las tesis de Chayanov para describir la explotación campesina, a saber: la familia es unidad de producción y de consumo, regula la explotación y emplea su propia mano de obra; la relación entre consumidores y trabajadores determina la intensidad del trabajo, es decir el grado de autoexplotación; asimismo, la productividad de cada unidad no despliega todo su potencial; finalmente, la producción no tiene un objetivo mercantil, orientándose en cambio al consumo familiar.

\footnotetext{
${ }^{81}$ WiCKHAM, C.: "Problems of comparing rural societies in early medieval western Europe", en Land \& Power, Studies in Italian and European Social History, 400-1200, British School at Rome, Lodon, 1994, p. 201 y ss; Versión en español: "Problemas de comparación de sociedades rurales en la Europa occidental de la temprana Edad Media", Anales de Historia Antigua y Medieval, Buenos Aires, 1996, vol. 29, pp. 45 y ss.

${ }^{82}$ GODELIER, M.: Economía, fetichismo y religión en las sociedades primitivas, Madrid: Siglo XXI, 1974, cap. 2.

${ }^{83}$ Un análisis que destaca y valora el modo campesino lo encontramos en DA GRACA, L.: "Peasant Mode of Production and the Evolution of Clientelar Relations", en DA GrACA, L. Y ZIGARELLI, A. (eds.): Studies on PreCapitalist Modes of Production.

${ }^{84}$ MARX, K.: "Formas que preceden a la producción capitalista", en GODELIER, M. (comp.): Antropología y economía, Barcelona: Anagrama, 1976, pp 26 y ss.

${ }^{85}$ DA GRACA, L.: "Peasant Mode of Production and the Evolution of Clientelar Relations".
} 
Wickham sigue en ciertos aspectos a las afirmaciones chayanovianas, aunque con respecto a la influencia que ejerce la aldea o la comunidad sobre la unidad campesina se aleja de la propuesta de Chayanov. Al entrar en escena los factores relacionados con los lazos sociales (el intercambio de regalos de origen reciprocitario que obliga y los consumos colectivos) la lógica individual se puede ver alterada, siendo la comunidad la que fije las pautas de consumo y de producción; por lo tanto, el motivo por el cual la gran mayoría de la población aldeana no incrementa la autoexplotación de la fuerza de trabajo ni acumula excedente se debe a los condicionantes aldeanos que no representan un gran estímulo, antes que a decisiones unifamiliares ${ }^{86}$.

En el modo campesino el intercambio de bienes entre los miembros de la comunidad se realiza en dos niveles que contrastan en objetivos y lógicas. El primero de ellos es el intercambio mercantil. Según los antropólogos en esta forma de intercambio la relación establecida entre el comprador y el vendedor concluye cuando los bienes trocados o comprados pasan a ser propiedad del comprador. Entre los dos actores no existe ningún tipo de obligación, se han relacionado sólo para satisfacer una necesidad puntual. Además, los objetos del trueque son completamente alienables, escindibles del vendedor ${ }^{87}$. El segundo tipo de intercambio es el constituido por el intercambio de dones agonísticos y no agonísticos.

En el intercambio no agonístico lo donado no es alienable, se transfiere su uso, pero no su propiedad; de esta manera se crea una deuda, un contradón equivalente, que a su vez obliga a re-donar. Así se fomenta una serie de dependencias y solidaridades recíprocas, con ventajas y obligaciones para ambas partes y, lo más importante, se gesta un equilibrio al mantener la igualdad de estatus entre los participantes de la transacción. La cadena de obligaciones construye un endeudamiento generalizado, suscitando una dinámica por la cual los bienes se redistribuyen, a la vez que asegura la cuota correspondiente a los aldeanos; aunque como dice Godelier la lógica del don y el contradón encierra mucho más:

"Es también, y más profundamente, la condición de la producción y de la reproducción de las relaciones sociales que constituyen el armazón específico de una sociedad y caracterizan los vínculos que se entablan entre individuos y grupos" $"$.

\footnotetext{
${ }^{86}$ WickHAM, C.: Una historia nueva de la Alta Edad Media..., p. 716.

${ }^{87}$ Godelier, M.: El enigma del don, Barcelona: Paidós, 1998, p. 68.

${ }^{88}$ Ibidem, p. 75.
} 
La entrega de dones supone también la intención de los sujetos de establecer relaciones sociales entre ellos. La entrega de dones agonísticos ${ }^{89}$ (Mauss emplea la noción de potlatch, derivado en concepto teórico, para referirse a estos) es parte fundamental de la dinámica social en el modo campesino. El principio de la entrega de esta clase de dones consiste en dar más que el otro con la intención consciente de endeudar y obligar de forma casi permanente, así se afirma el prestigio y sella la superioridad por sobre el otro, rompiendo el equilibrio de estatus. En sociedades de rango la importancia del regalo radica en su rol como creador de poder y como factor de cambio.

En el modo de producción campesino se regula el crecimiento de la población. Aquí vemos funcionar el modelo propuesto por Boserup ${ }^{90}$. En su opinión, considera acertado que en las primitivas comunidades el proceso del cambio agrícola es una adaptación al aumento gradual de la población, determinado por variaciones en el ritmo natural del crecimiento demográfico o por inmigración ${ }^{91}$. Desde esta premisa, Wickham sostiene que las comunidades del modo de producción campesino, para no intensificar el trabajo y no romper con la lógica de su sistema socioeconómico, restringen el aumento de la población a través de distintos mecanismos de control del crecimiento (matrimonios tardíos, control de la natalidad).

Este modo de producción constituye para Wickham un tipo ideal en el sentido weberiano, el cual tendría aplicación universal y podrían destinarse a diferentes regiones y tiempos ${ }^{92}$, ya que mediante la comparación histórica podrían contrastarse sus variables. Este

\footnotetext{
${ }^{89}$ Ibidem, p. 86.

${ }^{90}$ BoseruP, E.: Las condiciones del desarrollo en la agricultura. La economía del cambio agrario bajo la presión demográfica, Madrid: Editorial Tecnos, 1967, p 201. Sahlins en el estudio citado concluyó de manera similar. "Excepto en el caso teórico e improbable de que las normas tradicionales de acceso y trabajo concordaran con una explotación óptima de la tierra, una sociedad podría experimentar «presión de población» de varios tipos y en grados diferentes en densidades globales por debajo de su capacidad técnica de producción. Así el umbral de la presión demográfica no es una determinación absoluta de los medios de producción, sino que es relativo a la sociedad en cuestión. Además, dependen también de las instituciones locales el modo como se experimenta a nivel organizativo esta presión, el nivel del orden social al cual se le comunica, así como también el carácter de la respuesta", SAHLINS, M.: Economía de la Edad de Piedra, Madrid: Akal, 1987, p. 63.

${ }^{91}$ BOSERUP, E.: Las condiciones del desarrollo en la agricultura. La economía del cambio agrario bajo la presión demográfica...p. 200.

92“"El modo < campesino> cabría incluir a la totalidad de los cultivadores asentados y autónomos, excluyendo por tanto a los individuos dedicados a una explotación de tipo pastoril nómada y también a los cazadores y
} 
ha sido el objetivo del autor: comparar las sociedades reales con una construcción abstracta a fin de medir o evaluar las diferencias entre el fenómeno y el tipo ideal ${ }^{93}$. Esta característica impide que el modo campesino explique su propia transformación. Este aspecto ha sido señalado por diversos autores. Davison remarca su falta de dinámica, su gran estabilidad interna y la exigua motivación campesina para desarrollar tecnología o incrementar la productividad más allá de cierto punto ${ }^{94}$. Esta misma falencia la marca en un tono más crítico Miquel Barceló ${ }^{95}$. Por su parte, Harman señala que el modo campesino se debilita por su incapacidad de conceptualizar la dinámica de las relaciones sociales; además, en su opinión, es pertinente considerar el papel de las fuerzas productivas como factor de cambio ${ }^{96}$. Harman sugiere que el modo campesino debería contemplar la posibilidad de incluir los planteos de Moreland sobre cómo los pequeños cambios en la producción derivaron a largo plazo en la transformación del modo de producción ${ }^{97}$. De forma severa, Kirchner duda sobre la validez de la noción de Wickham para el estudio de las sociedades altomedievales, al remarcar que

recolectores, que poseen, según habré de argumentar, unos sistemas económicos diferentes, aunque con numerosas analogías”. WiCKHAM, C.: Una historia nueva de la Alta Edad Media ..., p. 1334.

${ }^{93}$ Este aspecto de la metodología de Wickham ha sido criticado por diversos autores y no lo seguiremos en este trabajo, recurrimos a los conceptos del autor de manera general con el propósito de delinear una caracterización estructural de la sociedad en cuestión. DA GRACA, L.: "Reflexiones metodológicas sobre el estudio comparativo de Chris Wickham" y ASTARITA, C.: "Construcción histórica y construcción historiográfica de la temprana Edad Media". Aunque la elaboración del modo campesino se realizó también a partir de conclusiones sobre comportamientos sociales y económicos observados por los antropólogos en sus estudios. Wickham toma las elaboraciones de Sahlins, Meillassoux, Mauss y Boseup, ente otros.

${ }^{94}$ DAVISON, N.: "Centuries of Transition", Historical Materialism, vol. 19, 2011, p. 91.

${ }^{95}$ BARCELÓ, M.: “Arqueología e historia medievales como historia”, en Quirós CASTILlo, J. A. (eds.): $L a$ materialidad de la historia: la arqueología en los inicios del siglo XXI, 2013.

${ }^{96}$ HARMAN, C.: “Chris Wickham's Framing the Early Middle Ages", Historical Materialism, vol. 19, 2011, pp. 98-105.

${ }^{97}$ Wickham reconsidera el lugar de las fuerzas productivas a raíz de las críticas recibidas por el poco lugar que le otorgó en su libro Framing... en: WicKhaM, C.: "Productive Force and the Economic Logic of the Feudal Mode of Production", Historical Materialism, 16, pp. 3-22, 2008. Traducción al castellano: WickHAM, C.: "Fuerzas productivas y lógica económica del modo de producción feudal", Sociedades Precapitalistas, vol. 1, 2, 1er semestre 2012.

http://www.sociedadesprecapitalistas.fahce.unlp.edu.ar/. Universidad Nacional de La Plata. Facultad de Humanidades y Ciencias de la Educación. Centro de Estudios de Historia Social Europea. Traducción de Pablo Sarachu y Sabrina Orlowski.

MoReland, J.: “Land and Power from Roman Britain to Anlgo-Saxon England?", Historical Materialism, vol. 19, 2011, p. 176-193. 
se construye con base en nociones teóricas desconociendo la información disponible sobre el funcionamiento de las economías campesinas proporcionada por la arqueología ${ }^{98}$.

También Astarita objeta la capacidad de los tipos ideales de explicar las continuidades y los cambios. Retoma la idea de sociedad de base campesina, y en su opinión Wickham infravalora este concepto como base teórica, cuya aplicación posibilita entender la construcción del sistema feudal a escala europea ${ }^{99}$.

Por su parte Da Graca defiende concretamente que el modo campesino es una “structure of reality” y, al contrario que Wickham y sus críticos, afirma que la dinámica del modo campesino explica el cambio estructural y sus modalidades ${ }^{100}$. Para comprobar su argumento destaca que la forma de propiedad del modo campesino favorece al desarrollo de desigualdades y acumulaciones privadas gracias a la apropiación individual de los productos. En este mismo sentido, Sarachu señala que

“es posible definir mínimamente el <modo de producción campesino> (...) como una abstracción conceptual en una realidad histórica de la forma concreta en que una determinada sociedad organiza la producción"101.

A pesar de las falencias señaladas, cada vez más historiadores encuadran sus tesis bajo los parámetros señalados por Wickham. Por ejemplo: Harper concluye que la transición de la sociedad romana a la post-romana en el Occidente europeo fue pasaje de una sociedad compleja a una mucho más simple en su forma de organización social y económica ${ }^{102}$. Feller también utiliza las premisas de Wickham para interpretar los primeros siglos de la Edad

\footnotetext{
${ }^{98}$ KIRCHNER, H.: "Sobre la arqueología de las aldeas altomedievales", Studia Historica. Historia Medieval, 28, 2010 , p. 252.

${ }^{99}$ AstaRITA, C.: "Construcción histórica y construcción historiográfica de la temprana Edad Media" ... Da Graca coincide en señalar que el mismo Wickham ha subestimado el potencial de su propio concepto al no enriquecer su formulación con vocabulario específico del materialismo histórico. DA GRACA, L.: "Peasant Mode of Production and the Evolution of Clientelar Relations", p. 158.

${ }^{100}$ DA GRACA, L.: "Peasant Mode of Production and the Evolution of Clientelar Relations". p. 160.

${ }^{101}$ SARACHU, P.: Patronazgo rural, dependencia y sociedad de base campesina en la Galia meridional (c. 400c. 550) (Tesis de posgrado). -- Presentada en Universidad Nacional de La Plata. Facultad de Humanidades y Ciencias de la Educación para optar al grado de Doctor en Historia. Disponible en:http://www.memoria.fahce.unlp.edu.ar/tesis/te.1176/te.1176.pdf, 2015, p. 220.

102 HARPER, K.: Slavery in the Late Roman World. AD 275-425, Cambridge: Cambridge University Press, 2011, p. 500 .
} 
Media $^{103}$. Por su parte, Grey se sirve del marco conceptual de las sociedades de base campesina para explicar la dinámica de las comunidades del mundo post-romano, enfatizando en las nociones de reciprocidad, competencia y solidaridad colectiva ${ }^{104}$.

Algunos historiadores españoles consideran a las sociedades altomedievales del espacio ibérico en términos de una sociedad de base campesina, aunque a diferencia nuestra ellos observan los siglos VIII y IX ${ }^{105}$.

Acordamos con Da Graca y Sarachu en entender el modo campesino como una estructura de la realidad, como el modo que dominó a la formación social visigoda alejándonos de la idea de que el modo campesino (considerado aisladamente) se identifica únicamente con una sociedad sin clases y sin cambios. Efectivamente, Wickham advirtió que estamos ante un tipo ideal susceptible de variaciones empíricas; de hecho, considera que en ciertos lugares durante la temprana Edad Media aristócratas y campesinos convivieron manteniendo relaciones en términos de obediencia y tributos, tal vez simbólicos, es decir un pago poco significativo en términos de extracción de excedente. Esta situación ha sido la que prevaleció en el norte europeo en el primer momento de la Edad Media ${ }^{106}$, pero que consideramos extensible a otras áreas del continente (sobre todo las cuestiones planteadas en torno a las relaciones sociales que siguen la lógica reciprocitaria).

\section{2}

\section{El contexto material de la sociedad visigoda}

\footnotetext{
${ }^{103}$ FelLer, L.: Campesinos y señores en la Edad Media: Siglos VIII-XV, Valencia: Universitat de València, 2015.

104 GreY, C.: Constructing Communities in the Late Roman Countryside, New York: Cambridge University Press, 2011.

105 MARTín VISO, I.: "Espacios sin estado. Los territorios occidentales entre el Duero y el Sistema Central (siglos VIII-IX)", en MARTín VISO, I. (ed.): ¿Tiempos oscuros? Territorio y sociedad en el centro de la Península Ibérica (siglos VII- X), Madrid: Silex, 2009. MARTín VISO, I.: "Hispania en el periodo postromano (siglos V-VIII)", en Monsalvo Antón, J.M. (ed.): Historia de la España medieval, Salamanca: Ediciones Universidad de Salamanca, 2014. BlANCO GONZÁlEZ, A.: "Espacios residenciales y productos del interior peninsular entre la Antigüedad Tardía y la Alta Edad Media. Propuestas desde la arqueología extensiva", en MARTín VISO, I. (ed.): ¿Tiempos oscuros? Territorio y sociedad en el centro de la Península Ibérica (siglos VII-X), Madrid: Silex, 2009.

106 WickHAM, C.: Una historia nueva de la Alta Edad Media, Europa y el mundo mediterráneo..., p. 477.
} 
En las páginas que siguen analizaremos los registros arqueológicos hallados en el medio rural del reino visigodo. Creemos que su sistematización nos permite proponer que el reino visigodo fue una sociedad en la cual las relaciones de explotación fueron asistemáticas. La considerable reducción del dominio político (y del radio de acción) le imposibilitó a la aristocracia dominar de forma regular a las comunidades rurales, de las cuales no pocas lograron autonomía a instancia de las ambiciones aristocráticas.

Alcance y problemas de la contribución arqueológica a la historia del hábitat rural visigodo

El estudio de los siglos posteriores a la caída del sistema imperial romano (como totalidad o en alguno de sus aspectos) debe sumar necesariamente los aportes provenientes de la arqueología. Los avances en esta disciplina proveen de un sinfín de evidencias físicas, localizaciones de nuevos yacimientos y desarrollos de secuencias estratigráficas que el historiador necesita atender. Aquellos que se sirvieron de estos avances, lograron investigaciones de notable éxito ${ }^{107}$. Sin embargo, la arqueología es una ciencia social que presenta para los historiadores ciertos problemas metodológicos.

En los últimos años los estudios arqueológicos sobre el medio rural ibérico visigodo (así como en el resto de Europa occidental) han crecido exponencialmente, permitiendo un conocimiento más certero sobre el paisaje rural de los siglos VI a principios del VIII. En general, los expertos concuerdan en que los asentamientos rústicos del reino visigodo no poseen un carácter monumental ${ }^{108}$. Al admitir esta característica, los pequeños indicios, como las alineaciones de cantos rodados o los pozos, estimulan la realización de prospecciones que derivan en estudios más profundos. Sin embargo, los nuevos descubrimientos y su difusión a través de los canales académicos no hacen el trabajo del historiador más sencillo.

En primer lugar, la variada geografía de la Península Ibérica y los desarrollos históricos marcadamente regionales obligan a los arqueólogos a trabajar en proyectos acotados a una región o localidad; el tiempo, el presupuesto asignado y la complejidad del procesamiento de los restos recuperados también inciden para que los resultados publicados se limiten a los sitios objeto de estudio, y en raras ocasiones se formulan modelos que superan

\footnotetext{
${ }^{107}$ Ejemplo de ellos son los trabajos de Wickham y Devroey.

${ }^{108}$ VigIL-ESCALERA, A.: "Nuevas perspectivas sobre la arqueología madrileña de época visigoda", Actas de las Primeras Jornadas de Patrimonio Arqueológico en la Comunidad de Madrid, 2005, p. 169.
} 
la escala regional ${ }^{109}$. Por lo tanto, si aspiramos a trabajar la economía campesina en la Península Ibérica de forma total es necesario realizar nuestra propia lectura de los reportes de los yacimientos y decidir a la luz de la evidencia las características que las comunidades campesinas de las diferentes regiones poseían en común y cuáles no.

La descripción física pormenorizada de los restos hallados es otra de las características de los estudios de arqueología. Muchas de las publicaciones tienen como objetivo solo dar a conocer nuevos elementos encontrados (hebillas, anillos, aretes, etc.) y discutir sobre la técnica de elaboración, estilo y materiales empleados. Otras realizan la descripción de todo un sitio poniendo en discusión secuencias estratigráficas, la ubicación relativa de cierto material e incluso realizan hipótesis sobre el significado social de sus descubrimientos. Como consecuencia, recibimos un cúmulo ciclópeo de información que necesitamos aprender a clasificar y, en muchos casos, desechar. Para realizar con éxito esta selección es imperante un buen manejo del lenguaje técnico específico, entender las diferentes ramas de la arqueología y comprender las teorías subyacentes (arqueología cultural, funcionalista, procesual o nueva arqueología); estas habilidades permitirán una lectura crítica de los informes y/o artículos. Solo una vez que la información arqueológica es sometida al proceso de jerarquización puede ser incluida en la investigación.

Los testimonios puros provenientes de los sitios arqueológicos rurales visigodos revelan importantes datos sobre las comunidades campesinas: los tipos y tamaños de los asentamientos, el diseño interno de las aldeas, los materiales de construcción de las casas, la cantidad de habitantes, la parcelación de la tierra, la capacidad y distribución de los silos, las diferentes especies de animales criados para consumo, las variedades de cereales y otros vegetales cultivados, las artesanías realizadas a escala local o regional y la ubicación de hornos, entre otros. Lo mismo sucede con las residencias consideradas centros aristocráticos. Sin embargo, los registros materiales no pueden más que darnos una imagen incompleta. A

${ }^{109}$ Olmo-EnCiso, L., CASTRO-PRIEGo, M.: "La época visigoda a través de la arqueología”, 711. Arqueología e historia entre dos mundos, Museo Arqueológico Regional, Alcalá de Henares, Madrid, 2012. QUIRÓs CASTILlo, J.A. (dir.): The archaeology of early medieval villages in Europe, Bilbao: Servicio Editorial de la Universidad del País Vasco, 2010. TeJERIZO-GARCÍA, C. et al.: "La construcción histórica de los paisajes en el sector central de la cuenca del Duero. Primeros resultados de una prospección intensiva", Territorio, Sociedad y Poder, Revista de Estudios Medievales, 2015, 10, p. 41. ARIÑo, E.: "El hábitat rural en la Península Ibérica entre finales del siglo IV y principios del VIII: un ensayo interpretativo", Antiquité Tardive, no 21, 2013, p. 95. Una notable excepción lo constituye: QUIRÓs CASTILlo, J.A. y BENGOETXEA ReMENTERIA, B.: Arqueología III. Arqueología medieval y posmedieval, Madrid: Universidad Nacional de Educación a distancia, 2013. 
través de ellos es imposible saber con certeza, por ejemplo, si los pobladores estaban sometidos a tributos, quién o quiénes eran dueños de las tierras, si libres y esclavos convivían, la influencia de las ciudades, si estaban bajo el mando de un poder político externo o la existencia de conflictos sociales internos. Por lo tanto, para tener un cuadro medianamente completo la mejor metodología es conjugar los hallazgos arqueológicos con las fuentes documentales. El uso de los escritos permite contextualizar e interpretar los hallazgos materiales; muchas veces sin los documentos escritos la evidencia física recolectada no permite sobrepasar el plano hipotético ${ }^{110}$.

No está de más decir que la arqueología ha proporcionado información sobre regiones y periodos de los cuales no existen documentos ${ }^{111}$. Sin embargo, como apunta Helena Kirchner $^{112}$, la documentación escrita es relegada por los arqueólogos en el momento de argumentar sus posiciones ${ }^{113}$. En cambio, algunos historiadores utilizan los registros materiales como un cuerpo documental más, realizando sobre ellos una exégesis propia de la disciplina histórica. Martín Viso, Castellanos, y Collins, entre otros, son algunos de los académicos que más colaboraron desde sus publicaciones para aunar la historia y la arqueología en el campo de los estudios visigodos.

El fin de las villas, el florecimiento de aldeas campesinas y los nuevos núcleos residenciales de la aristocracia

En el estado actual del conocimiento, el historiador Isla Frez ${ }^{114}$ y un conjunto de autores que se sirven de la arqueología ${ }^{115}$, coincidieron en afirmar que hacia el año 500 las

\footnotetext{
${ }^{110}$ MARTín VISO, I.: Asentamientos y paisajes rurales en el occidente medieval, Madrid: Síntesis, 2016. p. 9 y SS.

${ }^{111}$ Otros problemas son marcados por ARIÑO, E.: "El hábitat rural en la Península Ibérica entre finales del siglo IV y principios del VIII: un ensayo interpretativo" ...

112 KIRCHNER, H.: "Sobre la arqueología de las aldeas altomedievales".

${ }^{113}$ De forma similar: Quirós CAStillo, J.A. y BengoetXeA REMENTERIA, B.: Arqueología III. Arqueología medieval y posmedieval..., p. 23.

114 ISLA FREZ, A.: "El lugar de habitación de las aristocracias en época visigoda, siglos VI-VIII”, Arqueología y territorio medieval, 14, 2007.

115 Azkarate Garai-Olaun, A. \& Quirós Castillo, J.A.: “Arquitectura doméstica altomedieval en la Península Ibérica. Reflexiones a partir de las excavaciones arqueológicas de la Catedral de Santa María de Vitoria-Gasteiz, País Vasco", Archeologia Medievale, 28, 2001; VIGIL-EsCALERA, A.: "Arquitectura de tierra, piedra y madera en Madrid (ss. V-IX d.C.). Variables materiales, consideraciones sociales”, Arqueología de la Arquitectura, 2, 2003; QUIRÓs CASTILlO, J.A.: "La génesis del paisaje medieval en Álava: la formación de la
} 
villae clásicas hispanas desaparecieron como elemento estructurante del medio rural y como gestoras de la producción agraria ${ }^{116}$. En algunos casos se verifica el abandono total o parcial de las grandes haciendas, en otros se observa la instalación de familias campesinas organizadas en unidades domésticas nucleares, con la clara intención de reutilizar las estancias agrarias y economizar el material constructivo. Asimismo, se constata la transformación de los espacios áulicos en recintos de culto cristianos, proceso complejo relacionado con la fijación de las necrópolis pertenecientes a las comunidades ${ }^{117}$.

Existen varias líneas de interpretación sobre el abandono de las villas (y una abundante bibliografía que año a año aumenta). Quirós las sinteriza:

“(...) para algunos estudiosos, la sustitución de los grupos dirigentes como consecuencia de las invasiones explicaría en última instancia el abandono de los centros de gestión de la gran propiedad (...). Para A. Chavarría, la concentración de la propiedad en pocas manos explicaría el declive del sector residencial de muchas de estas villae en la primera fase, manteniéndose de todas formas la estructura productiva (...). Para otros autores, en cambio, la posesión de las villae está directamente relacionada con el concepto cultural e ideológico de romanidad por lo que su abandono supondría un cambio en los modelos culturales y en las

red aldeana", Arqueología y territorio medieval, 13, 2006; VIGIL-ESCALERA, A.:" Granjas y aldeas altomedievales al norte de Toledo (450-800 d C)", Archivo Español de Arqueología, 80, 2007; QUIRÓs CASTILlo J. A. \& Vigil EsCAlerA, A.:" Networks of peasant villages between Toledo and Uelegia Alabense, Northwestern Spain (Vth-Xth centuries)", Archeologia Medievale, 33, 2007; Quirós CASTILlo J. A.: "Las aldeas de los historiadores y de los arqueólogos en la Alta Edad Media del Norte Peninsular", Territorio, Sociedad y Poder, 2, 2007; Quirós CASTILlo, J.A: "La arqueología de las aldeas en el noroeste peninsular. Comunidades campesinas y poderes territoriales, siglo V-X", Monasterios, espacio y sociedad en la España cristiana medieval, XX Semana de Estudios Medievales, Nájera del 3 al 7 de agosto, Gobierno de La Rioja, Logroño, 2010; LÓPEZ QUIROGA, J. \& RodRÍGUEZ MARTIN, F.G.: "El < final> de las villae en Hispania I. La transformación de las pars urbana de las villae durante la Antigüedad Tardía", Portugalia, 21-22, 2000-2001; Quirós CASTILlo, J.A. (coord.): “Arqueología de la Alta Edad Media en el Cantábrico Oriental”, Actas Congreso Medio siglo de arqueología en el Cantábrico Oriental y su entorno, Vitoria-Gasteiz, 2009; QuIRós CASTILlo, J.A. (dir.): The archaeology of early medieval villages in Europe... ARIÑO, E.: "El hábitat rural en la Península Ibérica entre finales del siglo IV y principios del VIII: un ensayo interpretativo". CHAVARRÍA ARNAU, A.: "Interpreting the Transformation of Late Roman Villas: The case of Hispania", en ChrISTIE, N. (ed.): Landscape of Change. Rural Evolution in Late Antiquity and the Early Middle Ages, Inglaterra: Ashgate Publishing Company, 2004. ChaVARría ARnAU, A.: El final de las uillae en Hispania (siglos IV-VIII), BAT 7 , Turnhout: Brepols Publishers, 2006. En estos textos se condensa las ideas más importantes de la autora.

${ }^{116}$ Existen unas pocas excepciones. Ver: ARIÑO, E.: "El hábitat rural en la Península Ibérica entre finales del siglo IV y principios del VIII: un ensayo interpretativo".

${ }^{117}$ LÓPEZ QUIROGA, J. Y RODRÍGUEZ MARTíN, F. G.: < El "final” de las villae en Hispania. I. La transformación de las pars urbana de las villae durante la antigüedad tardía.>. 
formas de representación social (...). Por último, para otros autores, la militarización de la sociedad podría explicar que los grupos dirigentes perdiesen su interés por este tipo de asentamiento a favor de otras morfologías fortificadas u ocupaciones de altura"118

La desarticulación de las villas dio paso a una reestructuración del poblamiento rural ibérico $^{119}$. Los expertos, de forma consensuada, reconocen que los centros rurales dominaron el paisaje a partir de finales del siglo V hasta mediados del siglo VIII. La discusión que tiene lugar versa sobre el grado de autonomía de los campesinos habitantes de esos centros con respecto a la aristocracia. Volveremos sobre ese problema después de realizar una breve descripción de los sitios campesinos.

Los núcleos de poblaciones rurales se clasifican en dos tipos de asentamientos: la granja y la aldea. En diferentes escalas -menor para la granja- estos núcleos poseían en común la forma de organización espacial residencial, el aprovechamiento de los suelos y el nivel técnico de la producción artesanal. El origen de estos asentamientos ha sido diverso: pudieron formarse sin núcleos previos o estar asociados a diferentes tipos de residencias previas, como las villas.

Los enclaves poblacionales se ubicaban en planicies o elevaciones suaves cerca de los cursos de los ríos, sin contar la mayoría de ellas con muros defensivos. Además del área residencial constituida por los edificios familiares individuales, se encuentran el terreno destinado a la agricultura, las huertas, los pastos y los senderos que unían a las diversas estructuras; el uso parcelario del espacio agrícola poseía un gran dinamismo ${ }^{120}$. En algunas ocasiones se han detectado zanjas que se identifican como los límites de la aldea. La mayoría de los enclaves tenían asociado un espacio social de encuentro significativo para la comunidad; los más importantes serían la necrópolis y las iglesias, aunque también se incluyen en esta categoría a las construcciones destinadas para el albergue de las prensas o

\footnotetext{
118 Quirós Castillo, J.A. y BengoetXeA Rementeria, B.: Arqueología III. Arqueología medieval y posmedieval..., p. 152-153.

${ }^{119}$ VigIL-ESCALERA, A.: "Granjas y aldeas altomedievales al norte de Toledo (450-800 d C)".

${ }^{120}$ MARTÍN VISO, I.: Asentamientos y paisajes rurales en el occidente medieval..., pp. 37-56.
} 
los hornos de cerámica. El tamaño de los asentamientos fue variable, pudiendo estar compuesto por decenas de casas, algunas pocas o hasta por una sola unidad ${ }^{121}$.

Los enclaves aldeanos del ámbito visigodo también han dejado rastros en las fuentes escritas, aparte de los topónimos (que poco dicen sobre su naturaleza u organización).

Realizando un análisis sobre las leyes referidas a la fuga de esclavos, Isla Frez ${ }^{122}$ sostiene que hacia el siglo VII la voz villa ya denominaba a los asentamientos campesinos. Por la naturaleza de las fuentes es imposible conocer con certeza la composición poblacional de esos núcleos rurales o, mejor dicho, cuántos de los hombres que vivían allí eran libres, esclavos o libertos. Lo que sí afirmamos es que personajes de diversos estatus jurídicos compartían su lugar de residencia. Una ley de Égica ${ }^{123}$ clasificó como habitatores a todos los sujetos de una misma villa, encerrando en un mismo calificativo (y penándolos con un mismo castigo si refugiaran a un esclavo fugitivo) a ingenui y servi ${ }^{124}$. Isla Frez afirmó sobre este mismo término: "está revelando nuevas situaciones en las que un colectivo campesino es designado por la tierra que ocupa sin entrar en precisiones sobre su condición jurídica"125. También advirtió que

“(...) la normativa parece señalar la existencia de un cierto sentido de pertenencia a una comunidad y una cierta precisión geográfica de la misma, lo que nos remite a comunidades con un relativo grado de cohesión y organización. La ley menciona la obligada actuación de los habitatores en la expulsión del fugitivo de possessione sua, lo que pone de relieve que era este criterio, el de propiedad, uno de los elementos que habilitan la compresión del grupo humano en el espacio, pero parece tener más consistencia el denominado locus, que se sitúa

\footnotetext{
${ }^{121}$ Varios estudios han sistematizado la información de los cientos de sitios arqueológicos de forma similar. Ver por ejemplo QUiRós CASTILlo, J.A. y BengoetXeA RemEnTERIA, B.: Arqueología III. Arqueología medieval y posmedieval p. 178 y ss. TEJERIZO-GARCÍA, C.: "Early medieval household archaeology in Northwest Iberia (6th-11 th centuries)", Arqueología de la arquitectura, 9, 2012.

${ }^{122}$ ISLA FrEZ, A.: “'Villa, villula, castellum': Problemas de terminología rural en época visigoda”, Arqueología y territorio medieval, 8, 2001.

${ }^{123} \operatorname{LV} 9,1,21$, p. 363 y 364.

124 "Nam et ceteri habitatores loci illius seu cuiuscumque gentis uel generis homines, quorumlibet sint serui tam ecclesiarum quam etiam fisci nostri uel diuersorum possessorum, simili erunt sententia feriendi si fugitivum alteris nec prodiderint, nec de possessione sue in qua latitaverit foris expulerint", Ibidem 9, 1, 21, p. 364.

${ }^{125}$ ISLA FREZ, A.: “'Villa, villula, castellum': Problemas de terminología rural en época visigoda”, pp. 118-119.
} 
por encima de las referencias patrimoniales y que ha de aludir al hábitat campesino más allá de los vínculos de propiedad de la tierra"126

Esta conclusión del historiador es clave: la propiedad nominal de la tierra no aseguraba la real explotación.

Otro indicio documental que justifica la existencia de aldeas ocupadas tanto por libres como por no libres es la ley $2,4,10^{127}$; la misma sancionó que un siervo podría testificar en las disputas mantenidas por los vicinos possessores sobre títulos de tierras, viñas y edificios. Que un siervo conociera la procedencia de los títulos y los límites de las tierras permite inferir que mínimamente ha pasado un buen tiempo en un poblado compartiendo su rutina con los vecinos y herederos.

Además de la distinción existente entre libres y no libres ampliamente documentada, en los escritos hallamos otras distinciones: seniores loci $^{128}$, prioribus loci $^{129}$, honestioris loci persona $^{130}$, inferiores loci persona ${ }^{131}$, mediocriores $y$ viliores ${ }^{132}$. Estos apelativos corresponden aparentemente a distinciones socioeconómicas más que jurídicas. Algunos autores argumentan que ciertos signos visibles en los registros materiales señalarían una jerarquización social. Por ejemplo, en Gozquéz se encuentra evidencia de un intercambio comercial (hallazgos de restos de vasijas africanas) y bienes personales ornamentales en varias tumbas (el 34\% del total para el siglo VI, un 10\% para el VII); Quirós interpreta que los ajuares funerarios fueron parte de un ritual cuyo propósito ha sido demostrar el estatus de la familia del difunto a través de la destrucción social de la riqueza en un periodo de intensa competición social $^{133}$. Tal vez estemos frente a las huellas de la presencia de una elite local.

\footnotetext{
${ }^{126}$ Idem.

${ }^{127}$ LV 2, 4, 10 “ (...) certe nec de aliis causis nec de mairoribus rebus ese sibi credendum scient, nisi de minimis quibuscumque rebus ac de terris aut vineis aut vicinos possessores intentio exoriri”, p. 103.

${ }^{128}$ Ibidem 6, 1, 1, p. 246. “Ut domino vel senioribus loci petatur servus un crimine accusatus”. LV 8, 5, 6, p. 347-348.

${ }^{129}$ Ibidem 9, 1, 8 (Recc.) “Ut, ad euisis domum fugitivus venerit, vicinis et loci prioribus contestetur”, p. 356.

${ }^{130}$ Las referencias a las actas de los concilios de Toledo proceden de la edición de VIVES, J., MARÍN, T., MARTÍNEZ, G.: Concilios visigóticos e hispanos- romanos, Barcelona, Madrid, 1963, abreviándose Concilios, nombre del Concilio., completado con la referencia al año, al canon (c.) y página.

Concilios, Toledo III, año 589, p. 135.

131 Idem.

${ }^{132}$ LV 9, 2, 8, “Quid debeat observari, si scandalum infra fines Spanie exsurrexerit”, p. 372.

${ }^{133}$ Quirós CAstillo, J.A.: “Defensive Sites of the Early Middle Ages in North-West Spain”, p. 204.
} 
A pesar de existir una división estamental en el seno de las comunidades campesinas, Isla Frez argumenta que es posible encontrar en el año 700 una "vida aldeana" que englobaba a todos los habitantes ${ }^{134}$. Algún indicio de esta organización la descubrimos en las leyes.

Títulos y libros completos del cuerpo legal visigodo pormenorizan cómo deberían actuar todos los habitantes del reino ante el encuentro de un animal de granja perdido. Entre otros deberes ${ }^{135}$, el conjunto de los vecinos examinaría los daños producidos por los animales sueltos en los campos, viñedos y huertas y tasarían como colectivo la compensación debida al dueño de los bienes inmuebles afectados. Asimismo, si alguien colocase una trampa para animales advertiría a todos los vecinos para que no acudiesen sin cuidado al paraje ${ }^{136}$. También es interesante señalar la ley "Ut pro inventis animalibus erroneis publice denuntietur" ${ }^{\prime 137}$. La misma estableció que si alguno encontrara un animal avisaría aut sacerdoti aut comiti aut iudici aut senioribus loci aut loci aut etiamin conventu publico vicinorum $^{138}$. A la luz de esta norma, es lícito suponer que en esas asambleas públicas de vecinos se discutían y resolvían temas del interés de comunidades agrícolas ganaderas.

Más arriba mencionamos que las unidades domésticas fueron ocupadas por familias nucleares; las residencias conservan un diseño en común. Como en los casos de La Vega y El Pelícano en Madrid, del sitio de Vitoria- Gasteiz en la capital de Álava en el actual País Vasco, o de Muelas de Pan en Zamora ${ }^{139}$, los complejos habitacionales estaban formados por cabañas de suelo rehundido con forma rectangular u ovalada ${ }^{140}$, edificadas sobre zócalos de piedra, alzados de materiales perecederos, como el adobe o la madera, y techadas a una o dos aguas con tejas curvas. Según indican Azkarate Garai-Olaun y Quirós Castillo, el uso de materiales mixtos tuvo su paralelo con las construcciones halladas en la zona meridional de Europa, en especial en Italia ${ }^{141}$. Cada cabaña poseía un espacio central, que se identificó como la cocina (por encontrar restos de solares de hogares) y otras habitaciones auxiliares

\footnotetext{
${ }^{134}$ ISLA FREZ, A.: “El lugar de habitación de las aristocracias en época visigoda, siglos VI-VIII”. p. 11.

${ }^{135}$ LV 8, 3, 13- 17, p. 326-329.

136 Ibidem, 8, 4, 23, p. 340 .

${ }^{137}$ Ibidem 8, 5, 6, p. 347.

${ }^{138}$ Ibidem 8, 5, 6, p. 348.

139 AzKarate Garai-Olaun, A. \& Quirós CAstillo, J.A.: “Arquitectura doméstica altomedieval en la Península Ibérica. Reflexiones a partir de las excavaciones arqueológicas de la Catedral de Santa María de Vitoria-Gasteiz, País Vasco". p. 17.

${ }^{140}$ Ibidem, p. 19.

${ }^{141}$ Ibidem, p. 19.
} 
entendidas como establos o almacenes ${ }^{142}$; todas ellas estaban dispuestas en torno a un espacio abierto (un posible patio o un corral). Los arqueólogos relacionan a cada casa con un conjunto de estructuras anexas: pozos, zanjas, silos subterráneos destinados al guardado del cereal y, en algunos casos, espacios con hornos para cocer cerámica. Por citar sólo un caso, en el sitio de la Indiana (Pinto) se hallan doce cabañas de suelo rehundido y pozos asociados, zanjas y casi cien silos. El conjunto de espacios identificados como almacenes era, por lo tanto, de uso familiar. Ante estas pruebas deducimos que, si cada unidad nuclear guardaba sus cosechas de forma individual predominaban las parcelas propias explotadas por la familia y sus dependientes. Vigil- Escalera afirmó que luego del quiebre de las estructuras del Imperio romano, los medios de coerción aristocráticos fueron insuficientes, aunque "no por ello menos eficaces a la hora de gestionar la extracción de la renta hasta donde llegaron sus posibilidades"; sin embargo, ese desequilibrio pudo dar al campesinado "alguna posibilidad de elección". Para el autor, la posición de las comunidades rurales debió

"gozar de una posición de relativa fuerza, en pocas coyunturas históricas tan ventajosa, a la hora de renegociar su estatuto (relaciones con el estamento propietario y con los agentes del Estado) como clase subalterna" ${ }^{143}$.

Los autores citados coinciden en afirmar que en los sitios excavados la técnica fue homogénea. Siguiendo a los autores italianos Gelichi y Librenti ${ }^{144}$, Quirós Castillo y Azkarate Garai-Olaun plantean como una posible resolución a esta uniformidad que ciertas fases de las construcciones, como la preparación del adobe para las paredes, eran realizadas por un grupo de artesanos especializados itinerantes, mientras que las etapas más simples estaban a cargo de los propios campesinos.

Existen pruebas escritas de lo afirmado por los arqueólogos. Valerio junto a Saturnino, su hermano en la religión, proyectaron construir un oratorio en la roca, en la zona del páramo del monasterio en la zona del Bierzo. Como sus propios medios eran deficientes

\footnotetext{
${ }^{142}$ En su relato autobiográfico, Valerio del Bierzo describe "Quumque in quodam predio fruge ceteraque alimentorum subsidia sufficienter in suo reposuisset hospitio...”. VAL. Replic. p. 282.

${ }^{143}$ VigIL-ESCALERA, A.: "Granjas y aldeas altomedievales al norte de Toledo (450-800 d C)". p. 251.

${ }^{144}$ GELICHI, S. Y LIBRENTI, M.: "L' edilizia in legno altomedievale nell' Italia del nord: alcune osservazioni”, $I$ Congresso Nazionale di Argheologia Medeiivale (Pisa, 29-31 mayo 1997), Florencia, pp. 215-220.
} 
para semejante empresa, con la ayuda de unos fieles contrataron "multi operarii". Finalmente se alzó el templo dedicado a la Santa Cruz y a San Pantaleón. Posiblemente, los dos hombres religiosos trabajaron en la excavación, ya que en el siguiente pasaje Valerio cuenta cómo Saturnino fue gravemente herido en el pie por el desprendimiento de algunas piedras $^{145}$. Si en esta tarea compleja Valerio acudió a la pericia de ciertos artesanos, en la ocasión en que su sobrino Juan y su famulo Evagrio cimentaron unas habitaciones del monasterio no necesitaron solicitar ayuda adicional ${ }^{146}$.

Los arqueólogos también reflexionan sobre los significados socioeconómicos de los materiales empleados en las obras. En primer lugar, concluyen que, con la caída de la autoridad central del Imperio y la incapacidad de los estados herederos de mantener las estructuras fiscales funcionando, las canteras, el comercio y la actividad constructiva se desplomaron, suscitando un vuelco en las actividades artesanales ${ }^{147}$. A la vez que reconocieron la existencia de artesanos especializados que recorrían las comarcas brindando sus servicios, admitieron que las construcciones simples de materiales lígneos y perecederos (las más representativas de los sitios) se corresponderían con comunidades o estructuras familiares de ciclos productivos simples en las que no ha sido posible constatar una gran jerarquización social ${ }^{148}$.

El cultivo de los cereales (como el trigo, la cebada y en algunas ocasiones una especie de mijo) y la ganadería constituían la base de la economía. El trabajo agrícola se registró fehacientemente en el sitio de Bovalar; las viviendas de este paraje fueron selladas por una espesa capa de cenizas producto de un gran incendio, lo cual permitió desenterrar semillas de los cereales mencionados y encontrar evidencia de huertas de legumbres y frutales. Las diversas plantaciones están atestiguadas arqueológicamente también para otros sitios y en los documentos. El utillaje agrícola descubierto en los sitios se compone de hachas, podaderas, cencerros, pinzas, hoces y mangos torsionados de pala. El cultivo de la vid y del olivo fueron también actividades productivas básicas. En el poblado identificado como Parpalinas,

\footnotetext{
${ }^{145}$ VAL. Replic. pp. $297-299$.

146 Ibidem, p. 304.

147 Azkarate Garai-Olaun, A. \& Quirós Castillo, J.A.: "Arquitectura doméstica altomedieval en la Península Ibérica. Reflexiones a partir de las excavaciones arqueológicas de la Catedral de Santa María de Vitoria-Gasteiz, País Vasco". p. 20.

${ }^{148}$ Ibidem, pp. 20, 21 y ss.
} 
ubicado en el Valle de Ocón del Ebro Medio en la provincia de La Rioja, se ha localizado una pieza correspondiente a una prensa olearia o vinaria del tipo clásico de palanca y mástil atornillado al extremo del bloque, que hace de contrapeso ${ }^{149}$. En el Bovalar en Lérida, se encontró un torculum, que aún contenía semillas de uva, según de Palol, de seguro uso comunal $^{150}$. En cuanto a la ganadería, en todos los sitios se encontraron pruebas de la cría de aves de corral, así como de los animales de labor, como los bueyes y las vacas, porcinos y de ovicaprinos $^{151}$. En varios de los pasajes de Valerio están nombrados bueyes, mulos y toros como animales comunes de los ámbitos rurales ${ }^{152}$. Los animales de tiro eran utilizados para la labranza de los campos sembrados y la roturación de los nuevos. El canon cuarto del Concilio de Narbona del año 589 dicta:

"Ut omnis homo tam ingenuus quam servus ghotus, romanus, syrus, graecus vel iudaeus die dominico nullam operam faciant, nec boves iungantur, excepto si inmatandi necessitas incubuerit (...)" ${ }^{\prime 153}$.

La presencia de restos específicos de faunas los indica como la fuente segura de proteínas cárnicas, $\mathrm{y}$, además, los ovicaprinos aportaban la mayoría de la lana necesaria para la confección de los vestidos, que se hacían de forma artesanal en cada hogar. La

${ }^{149}$ Espinosa Ruiz, U.: "Buscando al San Millán histórico, el yacimiento de Parpalinas", Belezos: Revista de cultura popular y tradiciones de La Rioja, 2010, p. 90.

${ }^{150}$ DE PALOL, P.: "Las excavaciones del conjunto de <El Bolavar>, Seros (Segria, Lérida) y el reino de Akhila", Los visigodos. Historia y civilización. Antigüedad y cristianismo (Murcia) III, 1996, p. 515. Para detalles de la prensa típicas de la época ver: ESPINOSA RUIZ, U.: "Buscando al San Millán histórico, el yacimiento de Parpalinas". p. 88 y ss.

${ }^{151}$ VigiL-EsCALERA, A.: “Granjas y aldeas altomedievales al norte de Toledo (450-800 d C)”. p. 272 y ss. Rufí CAsals, I., Bujons, N., Costa Solë, A.: "Estudio del aprovechamiento animal en el yacimiento de la villa romana del Pla de l'Horta (Sarrià de Ter, Girona) a partir del registro arqueozoológico (s. II d.C.-V/VII d.C.)", Archaeofauna, 27, 2018, pp. 275-292. Las reglas comunes de los monasterios citan como alimento regular la carne de ovejas, citado por ORLANDIS, J.: Historia del Reino Visigodo Español, Madrid: Rialp, 1988, p. 265. En las Vidas de los Santos Padres de Mérida, se relata que el abad Nancto se dedica al cuidado de sus ovejas. VSPE, p. 24.

${ }^{152}$ En varios de los pasajes de Valerio están nombrados bueyes, mulos y toros como animales comunes de los ámbitos rurales, VAL. Ord., pp. 273 y 275; VAL. Replic., p. 285; VAL. Quod de super., p. 317. En las páginas citadas, los animales de tiro son robados o sufren vejaciones por parte de campesinos enviados por los enemigos de Valerio. La Vita Aemiliani narra los sucesos de los ladrones de los caballos de Emiliano. Tal vez las reiteradas descripciones sobre hechos delictivos que tienen como botín a los animales se deban pensar como consecuencias de la falta de estos. BRAU. VSE, p. 208.

${ }^{153}$ Concilios, Narbona, 589, c. IV, p. 147. 
diversificación económica y el policultivo fueron rasgos de las comunidades rurales del reino visigodo. Según Vigil-Escalera Guirado y Quirós esta tendencia "should be interpreted as strategy or risk minimization integral to the economic of the peasantry" 154.

La manufactura artesanal es que encontrada con mayor frecuencia y abundantemente en los asentamientos explorados es la cerámica. Además, se hallaron rastros de tejido, cestería, y de los subproductos derivados de los animales. En cada una de las casas sepultadas bajo las cenizas del sitio ubicado en Lérida, se descubrieron instrumentos de cardado de lana y de hilado; el tejido como una actividad artesanal primordial de las unidades campesinas también se atestigua en las fuentes escritas. Valerio rememora que estando en un páramo carente de todo se hizo cargo de la educación del hijo de unas personas de estatus elevado (bonorum filium), a cambio solamente pidió una capa de entretejido grueso que no permitiera el paso del agua ni del frío. Pasados dos años, la madre del muchacho todavía adeudaba el tejido, y en época de vendimia, cuando preparaba sus instrumentos, enfermó. Ante la desesperación, la familia acudió al santuario de san Félix, pero en el camino público un toro lastimó gravemente a la mujer. Entre ruegos y llantos, la familia pidió al santo Félix que la curase. El santo hizo su milagro, mas a cambio le ordenó que salde la deuda contraída con Valerio. A la siguiente mañana, la mujer recuperada totalmente se dispuso a tejer junto a sus hijas y ancillae ${ }^{155}$. De este relato inferimos claramente que el tejido era una actividad común entre los campesinos, aunque tal vez lo más interesante radique en cómo se llevó a cabo el tejido. Las mujeres de la familia, incluyendo a la madre, trabajaron a la par que sus dependientes. Además, es sumamente interesante observar que Valerio pidió un manto tejido a cambio de un servicio.

Siguiendo con el análisis sobre las artesanías, los arqueólogos llaman la atención sobre la correspondencia morfotipológica y técnica de los restos de cacharros pertenecientes a yacimientos alejados entre sí, a veces por medianas y largas distancias, y sobre la ausencia

\footnotetext{
${ }^{154}$ Vigil-Escalera, A.; Quirós Castillo, J. A.: "Early Medieval rural societies in NorthWest Spain: Archaeological reflections of fragmentation and convergence", en ESCALONA, J. Y REYNOLDS, A. (eds.): Scale and Scale Changes in the Early Medieval Ages. Exploring Landscape, local Society and the World beyond, Turnhout: Brepols Publishers, 2011, p.48. También: QuiRós CASTILlO, J.A.: "Early Medieval Villages in Spain in the light of European experience. New approaches in peasant archaeology", en QUIRÓs CASTILLO, J.A. (dir.): The archaeology of early medieval villages in Europe, Servicio Editorial de la Universidad del País Vasco, 2010, p. 22. VIGIL-ESCALERA, A.: "Granjas y aldeas altomedievales al norte de Toledo (450-800 d C)". p. 255. 155 VAL. Replic., pp. 285-289.
} 
de hornos alfareros en algunos sitios ${ }^{156}$. Este problema se resolvería, según Escalera-Vigil ${ }^{157}$, al igual que la repetición del estilo constructivo en madera, si se aceptase que las cerámicas eran elaboradas por artesanos alfareros itinerantes que intercambiaban su trabajo por géneros agrícolas faltantes en sus propias economías. Posiblemente estos artesanos se dedicasen a la actividad alfarera en los tiempos muertos de la agricultura.

Existen dos principales lecturas sobre la cultura material. Sintetizamos sus argumentos.

La primera corriente considera que la caída y desestructuración del Imperio permitió el surgimiento de nuevos hábitats rurales campesinos (como eran las aldeas y las granjas con continuidad del espacio utilizado por una villa, de nueva creación y/o colonización de nuevas tierras) y de centros de dominio aristocráticos locales (los castra y castella ${ }^{158}$. Para la Península Ibérica esta línea de interpretación la siguen Quirós, Vigil-Escalera, Escalona Monje, Tejerizo y Martín Viso ${ }^{159}$, entre otros. Los autores defienden que el bajo nivel de la

${ }^{156}$ Vigil- Escalera documentó el hallazgo de hornos alfareros en tres sitios: Arroyo Culebro- La Recomba (Leganés), Prado Viejo y Gózquez. “Granjas y aldeas altomedievales al norte de Toledo (450-800 d C)”. p. 273. En el sitio de Parpalinas, en el área del hábitat, se identifica un alfar.

157 Ibidem, p. 274.

${ }^{158}$ Para el alcance de este modelo en otras regiones de Europa ver: ChAVARRÍA ARNAU, A.: "¿Castillos en el aire?: paradigmas interpretativos "de moda" en la arqueología medieval española", De Mahoma a Carlomagno: los primeros tiempos (siglos VII-IX) /XXXIX Semana de Estudios Medievales, Estella, 17-20 de julio de 2012 y BROGIOLO, G.P.: "<Aristocrazie e champagne>" a una arqueología de los paisajes medievales", en CABALLERO Zoreda, L., Mateos Cruz, P. y Cordero Ruiz, T. (eds.): Visigodos y Omeyas. El Territorio, Anejos de Archivo Español de Arqueología, 61, Madrid: CSIC, pp. 9-20.

${ }^{159}$ ESCALONA MONGE, J.: Sociedad y territorio en la Alta Edad Media castellana: la formación del alfoz de Lara, Oxford: 2002. ESCALONA MONGE, J.: "Patrones de fragmentación territorial: el fin del mundo romano en la Meseta del Duero", en ESPINOSA, U. y CASTELlanos, S. (eds.).: Comunidades locales y dinámicas de poder en el norte de la península ibérica durante la Antigüedad tardía, Logroño: Universidad de La Rioja, 2006. pp. 165-199. ESCALONA MONGE, J.: "Conflicto religioso y territorialidad en un mundo en fragmentación: un ensayo comparativo del noroeste hispánico y Britania en los siglos IV-VI", en CASTELlanos, S. y MARTín VISO, I. (eds.): De Roma a los bárbaros. Poder central y horizontes locales en la cuenca del Duero, León: Universidad de León, 2008, pp. 171-204. MARTín VISO, I.: "La ordenación del territorio rural y la tributación en el suroeste de la Meseta del Duero (siglos VI-VII)", en Castellanos, S. y Martín Viso, I. (eds.): De Roma a los bárbaros. Poder central y horizontes locales en la cuenca del Duero, León: Universidad de León, 2008, pp. 227-261. MARTíN VISO, I.: "Un mundo en transformación: los espacios rurales en la Hispania postromana (siglos V-VIII)", en CABAllero Zoreda, L., Mateos CruZ, P. Y Cordero, T. (eds.), Visigodos y omeyas. El territorio, Anejos de Archivo Español de Arqueología, 61, 2011, pp. 31-63. MARTín VISO, I.: "Circuits of Power in a Fragmented Space: Gold Coinage in the Meseta del Duero (sixth-seventh centuries)", en EsCALONA, J. Y REYNOLDS, A. (eds.): Scale andScale Change in the Early Middle Ages: Exploring Landscape, Local Society, and the WorldBeyond, Turnhout: Brepols Publishers, 2011, pp. 215-252. MARTín VISO, I.: 
riqueza no ha sido un fenómeno privativo de los núcleos rurales clasificados como campesinos, también los sitios aristocráticos gozaron de esta característica, cuya consecuencia más visible fue la incapacidad de mantener o construir residencias que denotasen una alta jerarquización social. Esta corriente explicativa no niega la existencia de la aristocracia y plantea como desafío encontrar los sitios habitacionales de los protagonistas de las fuentes escritas, aceptando la decadencia y el parcial abandono de las ciudades.

Durante los siglos V-VII en la Península Ibérica los castra y castella fueron estructuras diferenciadas que dominaron el espacio rural luego de la caída del Imperio Romano (también se constata en todo el sur de Europa ${ }^{160}$ ). Los núcleos fortificados podrían tratarse de centros aristocráticos de la elite que ejercerían un dominio local ${ }^{161}$ y mantendrían

"Enterramientos, memoria social y paisaje en la Alta Edad Media: propuestas para un análisis de las tumbas excavadas en roca en el centro-oeste de la Península Ibérica», Zephyrus, LXIX, 2012, pp. 165-187. MARTín VISO, I.: "Colapso político y sociedades locales: el Noroeste de la península ibérica (siglos VIII-IX)", Reti Medievali Rivista, 17, 2. Quirós CAstillo, J. A. y Vigil-EsCALERA, A.: "Networks of peasant villages between Toledo and Uelegia Alabense, Northwestern Spain (v-xth centuries)", Archeologia Medievale, XXXIII, 2006, pp. 79-128. Quirós CAstillo, J. A. y Vigil-EsCAlerA, A.: "Dove sono i visigoti?", en EBANISTA, C. y ROTILI, M (eds.): Archeologia e storia delle migrazioni: Europa, Italia, Mediterraneo fra tarda età romana e alto medioevo, 2011, pp. 259-281. QUIRÓs CASTILLO, J. A.: The Archaeology of villages in the Early Middle Ages, 2010, Bilbao. QuiRós CASTILlO, J. A.: "Early medieval landscapes in northwestern Spain: local powers and communities, fifth-tenth centuries"; QUIRÓS CASTILLO, J. A.: "La arquitectura doméstica de los yacimientos rurales en torno al año 711", 711. Arqueología e historia entre dos mundos, Zona Arqueológica, 15. 2, 20011, pp. 63-82. VigIL-EsCALERA, A.: "Cabañas de época visigoda: evidencias arqueológicas al sur de Madrid. Tipología, elementos de datación y discusión”, Archivo Españolde Arqueología, 2000, 73, pp. 223-252. VIGIL-ESCALERA, A.: "Cerámicas tardorromanas y altomedievales de Madrid", en CABALlero, L. MAteos, P. Y Retuerce, M. (eds.): Cerámicas tardorromanas y altomedievales en la Península Ibérica. Ruptura y continuidad, 2003, Madrid, pp. 371-387.. VIGIL-ESCALERA, A.: "El modelo de poblamiento rural en la Meseta y algunas cuestiones de visibilidad arqueológica", en LÓPEZ QUIROGA, J., Martínez Tejera A. M. y Morín, De Pablos, J. (eds.): Galia e Hispania en el contexto de la presencia germánica (s. V-VII). Balance y perspectivas, Oxford: BAR, 2006, pp. 89-108.. VIGIL-ESCALERA, A.: "Granjas y aldeas altomedievales al norte de Toledo (450-800 d. C.)". VigIL-ESCALERA, A.: "Apuntes sobre la genealogía política de aldeas y granjas altomedievales", en MARTín VISO, I (ed.): ¿Tiempos oscuros? Territorios y sociedad en el centro de la Penínsulalbérica (siglos VII-X), pp. 31-44. VIGIL-ESCALERA, A.: "Las aldeas altomedievales madrileñas y su proceso formativo", en QUIRÓs CASTILLO, J. A. (ed.): The Archaeology of villages in the Early Middle Ages, Bilbao, 2010, pp. 315-339. VIGIL-ESCALERA, A.: "Formas de poblamiento rural en torno al 711: documentación arqueológica del centro peninsular", 711. Arqueología e historia entre dos mundos, Zona Arqueológica, 15, 2011, p. 189-211. VIGIL-ESCALERA, A.: "Is it really relevant the ethnicity of our historical subjects?”, Arqueología y territorio medieval, 18, 2011, pp. 45-53.

160 Quirós Castillo, J.A. y BengoetXea Rementeria, B.: Arqueología III. Arqueología medieval y posmedieval... p. 154.

${ }^{161}$ MARTín VISO, I.: "Colapso político y sociedades locales: el Noroeste de la península ibérica (siglos VIIIIX)”. p. 341). “(...) una amplia diversidad de aristocracias locales en un ambiente caracterizado por la escasa presencia directa de la autoridad central". 
con los campesinos distintos grados de relaciones de subordinación. Los arqueólogos e historiadores los identifican como lugares centrales (central places). Este término está constituyéndose como un concepto que define a un espacio como un punto focal de poder que articulaba a nivel local las distintas dimensiones sociales ${ }^{162}$.

Las excavaciones sobre los sitios clasificados como hábitats aristocráticos por su forma y función aún son parciales; por sus características, sus dimensiones y elementos funcionales tan variables estamos en presencia de un fenómeno complejo. Sin embargo, los datos hasta ahora recogidos permiten su estudio y sistematización. Quirós clasifica a las fortificaciones en tres categorías: 1) castillos con una ocupación del suelo de más de 20 hectáreas, con una notable complejidad urbanística, aunque con sistemas de defensa débiles e indicadores de una jerarquización social, como son los ricos ajuares; 2) el segundo grupo se caracterizó por un tamaño menor (entre 2 y 10 hectáreas), murallas fortificadas a veces precarias y otras de mayor complejidad; 3) las fortificaciones de menos de una hectárea, las cuales podrían haber sido parte de un sistema de fortificaciones, de centros de cultos o de pueblos con una densidad de población alta.

Martín Viso ordena el estudio de los sitios fortificados de la Meseta del Duero y resalta los marcadores arqueológicos ${ }^{163}$. En primer lugar, todos los castella por él analizados tienen un tamaño que los incluye en el segundo grupo establecido por Quirós (con excepción de Irueña). En todos constata la existencia de murallas sin cimientos que encerraron a estructuras residenciales. En cuanto a la cultura material, se recuperan cerámica común y cerámica gris estampillada; esta última indicaría la presencia de una elite que podría demandar bienes en un circuito comercial que superó la escala local. En los ajuares se hallaron - aunque no en grandes cantidades - puntas de lanzas y cuchillos. Para Vigil-

\footnotetext{
${ }^{162}$ MartíneZ JimÉneZ, J. Y TeJerizo García, C.: "Central Places in the Post-Roman Mediterranean: Regional Models for the Iberian Peninsula", Journal of Mediterranean Archaeology, 28, 1, 2015, pp. 105-132. Salvador Oyonate, J. A., Wood, J., CABallero Cobos, A.: "Central Places, Local Elites and International Politics: The Highlands of Granada and Byzantine-Visigothic Conflict, 550-630", Nottingham Medieval Studies, 62, 2018, pp. 1-32. MARTínEZ JIMÉNEZ, J.: "The Rural Hinterland of the Visigothic Capitals of Toledo and Reccopolis, between the Years 400-800 CE", en Authority and Control in the Countryside, Leiden, The Netherlands: Brill, 2018. Olmo-Enciso, L., Castro-Priego, M., Diarte-Blasco, P.: "Beside and within the walls of Reccopolis: social dynamics and landscape transformations of a new Visigothic urban foundation", Groma, 3, 2018, doi: 10.12977/groma14.

${ }^{163}$ MARTIN VISO, I.: "Castella y elites en el suroeste de la Meseta del Duero post-romana", en CATALÁN RAMOS, R., FUENTES MELGAR, P., SASTRE BLANCO, J.: Fortificaciones en la tardoantigüedad: élites y articulación del territorio (siglos V-VIII d.C.), La Ergástula, Madrid, 2014, pp. 247-274.
} 
Escalera estos restos estarían indicando una militarización social ${ }^{164}$, mientras que para Martin Viso serían parte de rituales que denotaban una diferenciación social y

"Deben entenderse como la representación funeraria de unas comunidades campesinas, en las que aparecen individuos caracterizados con esos materiales, quizá relacionados con las elites que controlan políticamente estos centros fortificados"165

Sobre la funcionalidad de estos castillos, los autores que defienden el modelo de la red aldeana señalaron que estas construcciones serían consecuencia de una reconfiguración de las zonas rurales productivas y del cambio paradigmático de las aristocracias y su dominación social. Estos sitios fortificados no habrían tenido un rol militar ni habrían sido construidos por orden del estado. Martin Viso destacó que:

"Este tipo de construcciones encaja con una empresa local ordenada por una elite interesada en la creación de tales lugares < castella y castra>, pero no por un estado capaz de homogeneizar esas labores ni muchos menos por un campesinado que difícilmente podría segregar voluntariamente parte de su tiempo de trabajo para erigir esas defensas"166

También se desprende de la sistematización de la información arqueológica que allí donde las ciudades continuaban teniendo una actividad importante las fortificaciones no tuvieron un desarrollo tal como en aquellos lugares en los cuales los sitios urbanos casi desaparecieron $^{167}$. Quirós plantea que en la Meseta —ámbito geográfico de mayor concentración de castillos - desde el principio del siglo VI el surgimiento de la densa red de aldeas campesinas debe vincularse con la consolidación de élites regionales - o subregionales - que podrían llegar a captar renta de la producción de estas aldeas. Este autor propone que la red de aldeas y el sistema castral que dominó el paisaje desde el siglo V se correspondió en primer lugar con "una lógica de explotación territorial de carácter

\footnotetext{
${ }^{164}$ VIGIL-ESCALERA, A.: "Las aldeas altomedievales madrileñas y su proceso formativo", pp. 627 y 628.

${ }^{165}$ MARTIN VISO, I.: "Castra y elites en el suroeste de la Meseta del Duero post-romana". p. 260.

${ }^{166}$ MARTIN VISO, I.: "Castra y elites en el suroeste de la Meseta del Duero post-romana". p. 251. QuIRós CAstillo, J.A. y BengoetXeA Rementeria, B.: Arqueología III. Arqueología medieval y posmedieval, p. 166. ${ }^{167}$ Ibidem, p. 252.
} 
campesino" 168 . Acordando con Martín Viso y Castellanos, destaca que fueron los poderes locales los que afirmaron este modo de residencia de las aristocracias; asimismo, en algunas ocasiones fueron parte del estado visigodo e incluso tuvieron un rol en el sistema fiscal. Sin embargo, enfatiza la inestabilidad de estos dominios sobre el territorio por la permanente competitividad intra- aristocrática. Por último, aclara que las aristocracias no solo se asentaron en los castra; las haciendas rurales y las iglesias constituyeron sitios vinculados a la aristocracia regional. Isla Frez estudia las referencias sobre los castra y castella en las fuentes escritas, y deduce que ambos términos referencian a centros de población fortificados que perdieron gradualmente el carácter militar, cuyos orígenes serían las antiguas villas o un castro $^{169}$.

Finalmente, luego de posicionarse sobre la funcionalidad social de estas fortificaciones, Martin Viso profundiza sobre la vinculación con el estado, con el regnum visigodo. En su opinión, en el siglo V el estado fue reemplazado por una serie de sujetos con capacidades políticas locales que se concentraron en las ciudades, en los centros religiosos y los castella. A medida que los reyes avanzaron en el control de la Península negociaron con estos pequeños poderes. Concluye que

“(...) el reino visigodo se expresa sobre el territorio a través de estos castella y de las elites que controlaban estos <lugares centrales>. El resultado fue la proliferación de <lugares centrales $>$ y de espacios cada vez menos jerarquizados y mal definidos, que sustituyeron a los modelos, altamente centralizados, de origen romano."170

Indicamos que estos autores no desconocen que el poder central visigodo utilizase un sistema de defensa para proteger al territorio, pero sostienen que ocuparon castillos del sistema defensivo del periodo anterior ${ }^{171}$.

En una posición antitética se encuentran otros autores; Chavarría Arnau la resume así:

168 Quirós Castillo, J.A. y BengoetXea Rementeria, B.: Arqueología III. Arqueología medieval y posmedieval..., p. 167.

${ }^{169}$ ISLA FREZ, A.: “'Villa, villula, castellum': Problemas de terminología rural en época visigoda”. p. 8.

${ }^{170}$ MARTIN VISO, I.: "Castra y elites en el suroeste de la Meseta del Duero post-romana”. p. 268.

${ }^{171}$ Ibidem, p. 252. 
"La segunda interpretación propone que no se produjo jamás la desaparición del control de las élites sobre el territorio, gracias a una sustitución de los propietarios romanos por nuevos poderes que siguieron controlando algunas áreas de la península desde los núcleos urbanos a través de un campesinado dependiente"172

Para esta autora los datos arqueológicos (características de los ajuares, los tipos de hábitats, los restos antropológicos) revelan comunidades agrícolas-ganaderas con una parte de la población dependiente instaladas por las élites visigodas que vivían en las ciudades ${ }^{173}$. Afirma que si bien la aristocracia se asentaba en los centros urbanos (Barcelona, Mérida, Toledo, por ejemplo) la dominación de los territorios rurales fue importante porque le otorgaba recursos en forma de impuestos y rentas ${ }^{174}$.

Por su parte, Ariño considera que los poblados asociados a las villas, así como los de nueva creación no tuvieron un proceso de diferenciación social

“(...) como sería esperable si los grupos humanos que residen en ellos pudieran gestionar de forma autónoma sus recursos. En nuestra opinión el nivel igualitario (y extremadamente pobre) que refleja la cultura material de estos poblados podría ser más bien el indicio de la existencia de una aristocracia vigilante que impide la promoción de poderes campesinos emergentes." 175

Claramente, este autor se distancia de las posiciones que siguen los planteos de Wickham, al interpretar los mismos indicadores de una forma totalmente opuesta. Argumenta, en línea con Chavarría Arnau, que la aristocracia promovió la instalación campesina en los sitios otrora pertenecientes a una villa y que continuaron ejerciendo el control de las grandes propiedades. Según su visión, la aristocracia "se mantuvo como el grupo social que detentaba la posesión y explotación de las tierras de forma mayoritaria y

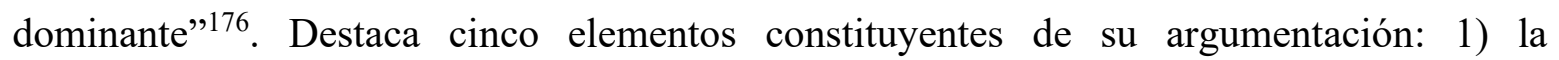

${ }^{172}$ Chavarría ARnAU, A.: “¿Castillos en el aire?: paradigmas interpretativos "de moda" en la arqueología medieval española". p .133.

${ }^{173}$ Ibidem, p. 154.

${ }^{174}$ Ibidem, p. 155.

${ }^{175}$ ARIÑO, E.: "El hábitat rural en la Península Ibérica entre finales del siglo IV y principios del VIII: un ensayo interpretativo". p. 107.

${ }^{176}$ Ibidem, p. 121. 
continuidad sin saltos entre el hábitat campesino y la villa; 2) el uso permitido por parte de la aristocracia de áreas residenciales inhabilitadas por parte de los campesinos para su reutilización; 3) presencia de iglesias en el solar de las antiguas villas; 4) cultivos especulativos (vino o aceite); 5) referencias escritas en las fuentes documentales ${ }^{177}$.

Chavarría Arnau, con el fin de criticar al modelo interpretativo con el cual desacuerda, consideró que los autores basan las mayorías de sus propuestas en dos (para ella) silogismos:

“(1) el ignorar completamente el cuadro político de referencia, es decir, las transformaciones que se produjeron en el sistema político, económico y social con la llegada de los bárbaros, (2) el asumir un bajo grado de poder aristocrático presente en el territorio" 178

La negación del primer punto la sustenta en los argumentos sintetizados más arriba. Para el segundo considera que para todo el periodo tardoantiguo y altomedieval hispánico se constata la presencia de núcleos jerárquicos urbanos o semi-urbanos de importancia religiosa, administrativa y fiscal; por lo tanto, encuentra muy difícil que el origen y desarrollo de una red de aldeas tuviera lugar sin la injerencia del dominio aristocrático. También advierte que la existencia de iglesias rurales indicaría una presencia fuerte de las elites en los ámbitos rurales. En la misma línea, Ariño propone que la aristocracia, tanto laica como eclesiástica, dedicó sus recursos a la edificación de iglesias y monasterios.

Chavarría Arnau en relación con las funciones de los castra y castella desestima los planteos de los autores previamente vistos. Para ella negar el carácter militar de estos sitios equivale a desconocer las características materiales y desestimar el contexto político conflictivo. Las fortificaciones fueron lugares centrales organizados para el control del territorio desde el estado, aunque reconoce que si se aceptara la participación de las élites locales, se explicaría las características heterogéneas de estos sitios ${ }^{179}$.

Las fuentes escritas sobre los sitios aristocráticos y sus consideraciones sobre el paisaje rural proveniente de las lecturas de los vestigios arqueológicos aportan elementos de

\footnotetext{
177 Ibidem, pp. 104-106.

178 CHAVARRÍA ARNAU, A.: “¿Castillos en el aire?: paradigmas interpretativos "de moda" en la arqueología medieval española”. p. 152.

${ }^{179}$ Ibidem, p. 157.
} 
naturaleza argumentativa a uno u otro modelo interpretativo. La mejor manera de comprender el problema es recurrir al concepto de formación social.

Antes de continuar daremos nuestra opinión sobre algunos de los argumentos resumidos. Advertimos que algunas de las afirmaciones que realizaremos luego se desprenden del análisis que desarrollamos a lo largo de esta tesis.

En primer lugar, lo que Chavarría Arnau considera un silogismo en nuestra opinión constituye una certeza. El poder de la aristocracia visigoda fue inestable, por lo tanto, la explotación del campesinado fue irregular y presentó diversas formas. Asimismo, las relaciones de dependencia fueron más laxas que estables y la entrega de la renta (si hubiera) no representó, en general, una quita considerable de los recursos campesinos. Martín Viso brinda una hipótesis muy sugerente, que tiene el potencial de explicar el cuadro de situación aquí descripto. Analizando restos de pizarras numerales encontradas en contextos de sitios campesinos, concluye que estas piezas estarían representando una

“captación basada en un dominio puntual, lo que se ajusta al modelo explicativo de unas elites locales que disfrutaban de un poder de tipo <político>, capturando tributos y controlando procesos productivos externos a ellas"180

Sugerimos que una buena parte de la población campesina mantuvo con la aristocracia o las elites locales relaciones de subordinación laxas. ¿Estamos en condiciones de aventurar que la lógica de la reciprocidad marcaba el ritmo de estas relaciones? Como veremos a lo largo de la investigación creemos que la respuesta es positiva.

Con respecto a las deducciones que realiza Ariño para defender la existencia de un fuerte dominio aristocrático señalamos que, en primer lugar, la tenencia de propiedad nominal no se tradujo necesariamente en explotación ${ }^{181}$; muchas veces las comunidades campesinas explotaban la tierra a título personal sin tener la propiedad plena de la misma.

\footnotetext{
${ }^{180}$ MARTín ViSO, I.: "Huellas del poder: pizarras y poblados campesinos en el centro de la península Ibérica (siglos V-VII)", Medievalismo: Boletín de la Sociedad Española de Estudios Medievales, 25, 2015, p. 309.

${ }^{181}$ AstARITA, C.: “Construcción histórica y construcción historiográfica de la temprana Edad Media”. p. 260.
} 
Con respecto a las iglesias propias, estas serían dotadas por familias campesinas acomodadas, sin la necesaria participación aristocrática ${ }^{182}$ y, según Chavarría Arnau esas iglesias recién se desarrollaron a partir de principios del siglo VII ${ }^{183}$. Por último, con respecto a las referencias sobre las fuentes escritas, una lectura prudencial de las mismas es sumamente recomendada. En páginas anteriores hemos advertido cómo ciertos datos documentales nos indicarían que estamos frente a una formación social campesina; aunque es cierto que muchos autores interpretan a las fuentes en otra clave, como observamos en el capítulo anterior.

Si bien el primer modelo interpretativo tiene mayor atractivo, y a nuestro entender explica mejor la realidad de la Península Ibérica de los siglos V-VIII, hay algunos aspectos que deberían ser matizados. Acordamos con Chavarría Arnau que es problemático borrar o reducir el carácter defensivo de los sitios fortificados, pues, como veremos en el siguiente capítulo, el reino visigodo experimentó a lo largo de sus siglos situaciones conflictivas casi de forma permanente. Quizá (y lo enunciamos a modo de hipótesis, ya que los datos hasta ahora recolectados no nos permiten avanzar más) las fortificaciones de las élites locales serían polifuncionales ${ }^{184}$. En el capítulo dedicado a la formación del ejército observaremos que la aristocracia reclutaba a los hombres en su área de influencia. Los campesinos dependientes y libres formaron parte de las huestes, por lo tanto, no resulta inverosímil que en una fortificación convivan registros de actividades agrícolas junto a vestigios militares. En la inscripción funeraria de Oppila se recordó que desde su residencia salió acompañado por un grupo armado con el encargo de trasladar armas; abatido en su misión, los compañeros regresaron con su cuerpo y en su tierra su familia lo despidió ${ }^{185}$. Este dato epigráfico junto a las evidencias encontradas en los ajuares refuerza nuestra posición.

\footnotetext{
${ }^{182}$ MARTín VISO, I.: Asentamientos y paisajes rurales en el occidente medieval... pp. 73-80. Ver la bibliografía sobre el tema en las páginas del autor citado.

${ }^{183}$ ChAVARRía ARNAU, A.: “¿Castillos en el aire?: paradigmas interpretativos "de moda" en la arqueología medieval española". p. 147 y ss.

${ }^{184}$ Tejerizo-García y Canosa-Betés advierten los múltiples roles de los sitios de altura de la Península Ibérica. TEJERIZO-GARCÍA, C. Y CANOSA-BETÉS, J.: "Power, control and social agency in post-roman northern Iberia: an archaeological analysis of hillfort occupations", Journal of Medieval Iberian Studies, 10, 2018, pp. 295-323.

${ }^{185}$ La lápida de Oppila reza así:

"Haec cava saxa- Oppilani

contine(n)t membra (Claro nit)or(e) natalium-

gestu abtiuq(ue) co(nspi)cu(um). Opibus quippe pollens - et ar
} 
Más problemático es concluir sobre si el poder central en Toledo tuvo algún tipo de injerencia sobre estas fortificaciones controladas por las aristocracias locales. Sin embargo, nos inclinamos por la negativa, pues la debilidad estructural de la realeza no permitiría canalizar recursos para la construcción y/o mantenimiento de varios centros fortificados. Además, no hay ningún registro que evidencie una iniciativa regia de la construcción de este tipo de lugares, como sí lo hay sobre la reconstrucción de las ciudades después de un asedio. Sin embargo, nos resulta verosímil que los hombres de mejor posición social utilizaren sus propios castella para organizar la defensa de su territorio, y que eventualmente los reyes aprovechasen estos centros como puntos de partida de sus expediciones o se abastecieran allí en su ruta.

Por otro lado, hay autores que defendieron que la adopción de la vida en castillos se debió al cambio en los patrones culturales de la aristocracia. Comprobaremos en el último capítulo que los grandes del reino laicos poseían una cultura militar. Por lo tanto, observamos la concordancia entre las pautas culturales de comportamiento, los registros materiales y las expresiones ideológicas. Esta explicación no anula a la primera que detallamos, al contrario, ayuda a entender el fenómeno desde todas sus aristas.

Por último, es necesario revalorizar el papel de la realeza y su grupo de fideles regis en la articulación territorial. Si bien el protagonismo de las aristocracias locales fue significativo, también lo fue el del rey. Los jefes máximos del reino, luego de Leovigildo,

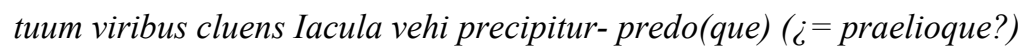

Bacceis destinatur. In procintum belli necatur-,

opitulatione sodalium desolatu(r), Naviter cede perculsum-

cli(e)ntes repiunt peremtum. Exanimis dom(u)m reducitur-

suis a vernulis humatur. Lug(e)t coniux cum liberis-,

fletib(u)s p(er)strepit. Decies (u)t ternos- ad quater-

quaternos vixit per annos. Pridie Septemb(r)rium idus

morte a Vasconibus mulatus. Era sexcentesima et octagensima

id gestum memento. Sepultus est sub d(ie) quies-cit

VI id(us) Octubres".

En: ICERV n ${ }^{\circ} 287$.

Sobre esta inscripción en particular ver: FONTAINE,, J.: "Une épitaphe rythmique d'un contemporain d'Isidore de Séville: l'éloge funèbre du Visigot Oppila", en Van Uytfanghe, M. y Demeulenaere, R. (eds.): Aevum inter utrumque: Mélanges offerts à Gabriel Sanders, professeur émérite à l'Université de Gand, Turnhou: Brepols Publishers, 1991, pp. 163-186. Sobre el estado actual de las ediciones de las inscripciones ver: SANTIAGO FERNÁNDEZ, J.: "El hábito epigráfico en la Hispania visigoda", VIII Jornadas Cientificas sobre Documentación de la Hispania altomedieval: (siglos VI-C), Madrid:P UCM, 2009. 
controlaron una fuente de recursos para nada desdeñable y haciendo uso de sus prerrogativas políticas entregaron tierras en forma de recompensas, a la vez que confiscaron otras a través de las armas legales que su posición privilegiada les concedía. En el capítulo cuatro observaremos el funcionamiento de los repartos y arrebatos de los premios. Aquí diremos que, en nuestra opinión, las aristocracias locales buscaron el contacto con el poder central regio, pues pertenecer al círculo regio (Königsnähe) tenía sus beneficios: el más inmediato fue recibir una posesión de tierras (como el caso de Nancto que veremos luego ${ }^{186}$ ) o cobrar impuestos en nombre del fisco ${ }^{187}$. También el contacto con el rey elevaba el prestigio del aristócrata, legitimaba su actuación como organizador de las huestes para participar de las expediciones regias, e incluso sancionaban a aquellos que no cumplían con las normas, beneficiándose de la absorción del patrimonio de los castigados (estos aspectos son desarrollados en el capítulo cuatro). Damián Fernández sostiene la importancia de disponer de una parte del poder que confiere el estado para sostener el estatus de las elites locales, por ello considera que la distinción entre agentes locales y agentes centrales constituye más una herramienta analítica que un dato objetivo de la realidad social visigoda ${ }^{188}$.

Acabado el análisis del hábitat rural visigodo, recurrir al concepto de formación social para su estudio es una solución para las evidencias encontradas. Una formación social de base campesina contempla la convivencia de aristócratas con un colectivo campesino autónomo junto a otras situaciones de mayor opresión; pero fue la formación social campesina la que imprimió la lógica al sistema social.

\footnotetext{
186 Ver p. 94 y ss.

${ }^{187}$ MARTín VISO, I.: “Tributación y escenarios locales en el centro de la Península Ibérica. Algunas hipótesis a partir del análisis de las pizarras visigodas", Antiquité Tardive, 14, 2006, pp. 263-290.

188 FERNÁNDEZ, D.: Aristocrats and Statehood in Western Iberia, 300-600 C.E..., pp. 226-227.
} 


\section{CAPÍtulo 3}

\section{LAS BASES MATERIALES DE LOS REYES EN UNA FORMACIÓN SOCIAL CAMPESINA}

\section{Nota historiográfica y planteo del problema}

Morsel plantea que la entrada de los pueblos germanos supuso una recomposición de la aristocracia fundiaria a través de la circulación y control de las tierras ${ }^{189}$. Según este autor, los nobilis de origen germano se instalaron en suelo romano por vía de repartos e integrado a la clase senatorial a través del proceso de etnogénesis y de alianzas políticas, la mayoría de las veces selladas con arreglos matrimoniales. A través de estos procesos surgió en cada reino un nuevo grupo social dominante que se identificó con una etnia en particular, en España la goda. Una línea de investigación propone que este sector de la sociedad basaba su riqueza y su dominio en la posesión y explotación de las tierras ${ }^{190}$.

Como hemos visto en el recuento historiográfico y en el anterior capítulo, numerosos autores sostienen que la aristocracia altomedieval dispuso de grandes posesiones de tierra, que se traduce en una base de poder fruto de la explotación de estas. Wickham, en su estudio sobre la gestión de la tierra en el Occidente temprano medieval, argumenta que en los dominios aristocráticos los trabajos agrícolas eran realizados por dependientes; el grado de

\footnotetext{
${ }^{189}$ Morssel, J.: La aristocracia medieval. El dominio social en occidente (siglos $V$ - $X V$ ), Valencia: Universitat de València, 2008.

190 Entre otros: MoRsSEL, J.: La aristocracia medieval...; WICKHAM, C.: Una historia nueva de la Alta Edad Media...; MCKITTERICK, R.: The Early Middle Ages. Europe 400-1000, New York: Oxford University Press, 2001. DÍAZ MARTíNEZ, P.C.: “El reino visigodo en vísperas del 711: sistema político y administración”, p. 32.
} 
dependencia variaba en cada caso en particular, desde siervos hasta arrendatarios libres y no libres $^{191}$.

Una larga controversia existe desde hace tiempo entre los historiadores sobre la forma de adquisición del patrimonio por parte de los aristócratas visigodos una vez que llegaron a la Galia e ingresaron a Hispania ${ }^{192}$, sobre la toma de las tierras y la continuidad del aparato fiscal.

Díaz Martínez admite que una vez que los godos se adentraron en la Península, el poder romano ya había caído, y los recién llegados ocuparon las tierras por su derecho de conquista $^{193}$. Además, sugiere que hubo un ensamblaje cuasi pacífico entre los provinciales y los visigodos, formándose al pasar poco tiempo una sola aristocracia terrateniente y las expropiaciones masivas no fueron necesarias. Por un simple mecanismo de sustitución de poderes, todas las posesiones otrora imperiales pasaron a manos de los reyes ${ }^{194}$. En un sentido similar, Barnish identifica este mismo fenómeno, pero aclara que no podemos negar el intento de los reyes de mantener las redes fiscales ${ }^{195}$. Por uno o ambos procesos la aristocracia, y los reyes principalmente, pasaron a controlar una vasta cantidad de recursos.

Uno de los medios por el cual los grandes del reino se aseguraban para sí el acceso a la tierra y su control efectivo ha sido la vinculación con el rey, disfrutar de la cercanía al rey (Königsnähe), término que comprende todos los beneficios que una estrecha y fuerte relación con el rey podía brindar ${ }^{196}$. Según este enfoque, el servicio y la lealtad eran recompensados,

${ }^{191}$ WickHAm, C.: Una historia nueva de la Alta Edad Media ..., cap. 5, p 378 y ss.

192 Sobre el asentamiento de los godos en el siglo V ver: JiMÉNEZ GARNICA, A. M.: Nuevas Gentes, Nuevo Imperio: Los Godos y Occidente en el siglo V, Madrid: UNED, 2010, pp. 83 y ss. Asimismo ver la bibliografía citada sobre este problema en: DíAz MARTíNEZ, P.C.: "La dinámica del poder y la defensa del territorio: para una comprensión del fin del reino visigodo de Toledo". HALSALL, G.: Las migraciones bárbaras y el occidente romano..., cap. 13.

${ }^{193}$ Afirmación compartida por ChAVARRÍA ARNAU, A.: “¿Castillos en el aire?: paradigmas interpretativos "de moda" en la arqueología medieval española". p.155.

${ }^{194}$ DÍAZ MARTíNEZ, P.C.: "La dinámica del poder y la defensa del territorio: para una comprensión del fin del reino visigodo de Toledo". p. 94.

195 "It is, though, quite possible that Visigothic sortes derived from the fifth century annexations, particularly in Spain, may have had a different status, as based on right of conquest, rather than the original foedus. Yet we cannot doubt that their kings will have tried to tax wherever possible". BARNISH, S.J.B.: "Taxation, Land and Barbarian Settlement in the Western Empire", Papers of the British School at Rome, 54, 1986, p. 193.

${ }^{196}$ Este término se impuso en los estudios sobre los carolingios a partir de los escritos de Tellenbach de 1939 (junto al también muy conocido Reichsaristokratie). Ver: AIRLIE, S.: "The arcistocracy", en MCKITTERICK, R. (ed.): The New Cambridge Medieval History, Cambridge: University of Cambridge, 1995. p. 433. Ver también: MCKITTERICK, R.: The Early Middle Ages... 
la mayoría de las veces y en preferencia, con porciones de tierra. Esto fue posible porque los reyes, como cabezas de las administraciones estatales de las exprovincias romanas, tenían bajo su control las tierras públicas y aquellas confiscadas a los traidores.

Asimismo, existe una visión historiográfica sobre el carácter regresivo de la economía durante los primeros siglos de la Edad Media ${ }^{197}$, la cual está conectada con la escuela que enfatiza la decadencia y caída del Imperio Romano en todos sus aspectos (Heather y WardPerkins son autores representativos de esta visión ${ }^{198}$ ). Otra postura prefiere caracterizar a la situación económica no como un empobrecimiento general, sino como el resultado de la simplificación de la economía debido a los cambios operados sobre la gestión de la tierra por parte del campesinado, la reducción de la red fiscal y las pautas de consumo y prácticas culturales, principalmente de la aristocracia ${ }^{199}$; un lento proceso de transformación y adopción serían las claves del periodo.

Aceptando una u otra explicación (la primera enfatiza el derrumbe imperial y la violencia del periodo y la segunda pondera en exceso el proceso de cambio como una adaptación continua) es claro que la desarticulación del Imperio Romano tuvo como consecuencia una contracción económica, por lo tanto, la aristocracia fue más pobre en términos materiales. Ahora bien, los especialistas discuten la raíz principal del empobrecimiento de la aristocracia: si ha sido producto de la reducción y simplificación de la escala de las estructuras del sistema económico (por ejemplo, las redes comerciales tuvieron solo un alcance local o regional en el mejor de los casos) o de la crisis del sistema de dominación política y económica.

Por nuestra parte consideramos que el dominio formal sobre grandes extensiones de tierra no implicaba una extracción regular del excedente por parte de la aristocracia. Como analizamos en el capítulo anterior, la explotación del suelo arable y de los recursos naturales estuvo en manos de los campesinos que debían o no (de acuerdo con su relación social)

\footnotetext{
${ }^{197}$ Representada principalmente por DUBY, G.: Guerreros y campesinos: Desarrollo inicial de la economía europea (500-1200), México: Siglo XXI, 1976 y FossiER, R.: La sociedad medieval, Barcelona: Crítica, 1996. ${ }^{198}$ HEATHER, P.: La caída del Imperio Romano, Barcelona: Crítica, 2006. WARD-PERKINS, B.: The fall of Rome and the end of civilization, Oxford: Oxford University Press, 2005. Las ideas de Gibbon sobre este problema están presentes en esta escuela.

199 Ver principalmente WiCKHAM, C.: Una historia nueva de la Alta Edad Media... En el ámbito español condensa esta visión MARTín VISO, I.: "Hispania en el periodo postromano (siglos V-VIII)". pp. 42 y 43.
} 
entregar una parte de su trabajo a la aristocracia. La explotación limitada de la mano de obra (registrada en la fuga de siervos, la indocilidad de los mismos y la gran masa de campesinos autónomos) y los condicionantes generales del reino visigodo (guerras contra los pueblos extranjeros, las razias de los pueblos asentados en el interior de la Península Ibérica, las epidemias, la baja producción agrícola y las hambrunas) restringieron las bases económicas de la aristocracia visigoda, que fundamentaban gran parte de su riqueza en la explotación de las tierras.

Ante un escenario económico pernicioso para la aristocracia, muchos de los grandes del reino y miembros de las elites locales se volcaron a participar en las políticas del gobierno central. Lograr la vinculación con el rey a través de una relación de fidelidad podría constituir una forma de asegurarse la reproducción material. Sin embargo, los reyes, como el conjunto de la aristocracia, controlaron una limitada fuente de recursos. Por un lado, los circuitos de recaudación fiscal estatal estaban en pleno retroceso y, por otro, las tierras fiscales sufrían los mismos inconvenientes que las tierras de los particulares con relación a la obtención de rentas. Entonces, los bienes a repartir fueron escasos — si bien es cierto que las arcas regias se veían alimentadas por un flujo casi constante de ingresos, también éstos eran repartidos de forma casi inmediata.

Por lo expuesto, a partir de ahora trabajaremos sobre una de las variables de la inestabilidad del poder regio visigodo: las bases materiales restringidas. Para ello, en primer lugar, describiremos las condiciones generales del reino a fin de demostrar que asistimos a una fase de simplificación de los ciclos económicos agravados por el alto conflicto social y político. Una vez visto el contexto general, en lo subsiguiente analizaremos las vías de enriquecimiento de los reyes visigodos que presentaban dos formas de explotación: la interna y la externa.

\section{1}

\section{Condicionantes económicos generales del reino visigodo de Toledo}

Guerras, pestes, plagas y hambrunas

Las guerras, las pestes, las plagas y las hambrunas fueron estudiadas por numerosos autores como factores que provocaron la caída demográfica de los sectores más pobres de 
Hispania $^{200}$, pero sólo de forma tangencial se los califica como condicionantes de la productividad agrícola ${ }^{201}$ o como estimulantes de los cambios sociopolíticos ${ }^{202}$. Nuestro propósito aquí es ponderar dichos factores como agentes que perturbaron la economía general del reino godo.

El estado de conflictividad casi permanente, fruto de las guerras y querellas aristocráticas, sumía a las regiones afectadas en largos periodos de crisis de producción. Los territorios sublevados a la autoridad regia eran sometidos al saqueo, mientras que las comarcas leales se veían en la obligación de satisfacer las necesidades de los ejércitos ${ }^{203}$.

Luego de la derrota de los visigodos de Tolosa en el año 507 y su posterior establecimiento definitivo en la Península Ibérica, los primeros aristócratas godos proclamados reyes después del interregno ostrogodo (507-549) 204 (Agila, Atanagildo, Liuva I y Leovigildo) debieron regir sobre un territorio económica y políticamente desarticulado ${ }^{205}$. Las fuentes contemporáneas señalan las dificultades que enfrentó el núcleo aristocrático dominante en el plano político para conquistar las tierras que aspiraba gobernar.

Uno de los obstáculos para controlar el territorio peninsular fue el deseo de algunos centros de población de continuar siendo autónomos, condición obtenida gracias al deterioro del dominio imperial romano. Martín Viso sostiene que

“(...) uno de los aspectos que debe resaltarse (...) es la efervescencia de los poderes locales. Una vez desaparecido el horizonte imperial, las aristocracias regionales se vuelcan hacia nuevos horizontes más locales"206

\footnotetext{
${ }^{200}$ Orlandis, J.: Historia del Reino Visigodo Español..., pp. 208 y ss. LORING, Ma. I., PÉREZ, S. Y FUENTES, P.: La Hispania tardorromana y visigoda..., p. 209 y ss.

201 Un ejemplo es el estudio de GARCÍA MORENO, L.A.: "El campesino hispanovisigodo entre bajos rendimientos y catástrofes naturales. Su incidencia demográfica”, Los visigodos. Historia y civilización. Antigüedad y Cristianismo, Murcia, IKl, 1986.

202 BARCEló, M.: “Les plagues de llagost a la Carpetania, 578-649”, Estudis d'história agraria, 1, 1978, pp. 67-84.

${ }^{203}$ García Moreno apuntó que las acciones bélicas devastaban las regiones agrícolas y extinguían una buena parte de la cabaña ganadera. GARCíA Moreno, L.A.: Historia de España Visigoda ..., p. 222.

${ }^{204}$ LORING, Ma. I., PÉREZ, S. Y FUENTES, P.: La Hispania tardorromana y visigoda ..., p. 137 y ss.

${ }^{205}$ Ver: WICKHAM, C.: Una historia nueva de la Alta Edad Media ... y MARTíN VISO, I.: "Hispania en el periodo postromano (siglos V-VIII)", pp. 30-32.

${ }^{206}$ MARTín VISO, I.: “Hispania en el periodo postromano (siglos V-VIII)”, pp. 30.
} 
Las fuentes escritas reflejan este fenómeno. En el año 550 la ciudad de Córdoba se levantó contra la autoridad del rey Agila ${ }^{207}$, quien fracasó en sus intentos de someterla y perdió en esa contienda gran parte del tesoro godo ${ }^{208}$. Al año siguiente, Agila no sólo continuó con su lucha contra dicha ciudad, sino que además debió enfrentar la rebelión de Atanagildo, cuyo objetivo fue ser reconocido como el rey de todos los visigodos. Este último realizó un llamado de auxilio a los bizantinos con el fin de asegurar su triunfo militar. Luego del éxito de Atanagildo, los imperiales no abandonaron las tierras ibéricas, al contrario, se instalaron en las regiones mediterráneas de la Baetica, llegando a Cádiz, y en la provincia de la Cartaginensis hasta Valencia ${ }^{209}$, haciendo efectivo un acuerdo firmado por el entonces rebelde magnate ${ }^{210}$ y el emperador Justiniano. Los asentamientos bizantinos de la Península, por casi una centuria, constituyeron un inconveniente más para los reyes godos, pues les imposibilitaban el control efectivo del territorio, el cual consideraban de su jurisdicción por el derecho de conquista ${ }^{211}$. Durante el reinado de Atanagildo, Córdoba se rebeló nuevamente y sostuvo su autonomía hasta el año 572; Sevilla, por su parte, actuó de manera similar manteniendo su soberanía hasta el año $567^{212}$. Por otro lado, el reino suevo — convertido al catolicismo por Martín de Braga en el año 550 - mantuvo la condición de bastión independiente, lo cual estorbó la territorialización ${ }^{213}$ del poder godo sobre la Península hasta casi finales del siglo VI.

Juan de Bíclaro e Isidoro de Sevilla escribieron sobre los acontecimientos del último cuarto del siglo VI y de las primeras décadas del VII, brindando algunos detalles sobre las campañas bélicas realizadas por el rey Leovigildo. La intención de estas fuentes es exaltar el

\footnotetext{
207 ISID. Hist. Goth., p. 247.

208 Ibidem, sección 45, pp. 246-248.

${ }^{209}$ DíAZ MARTíneZ, P.C.: Hispania tardoantigua y visigoda ..., p. 352.

${ }^{210}$ LorIng, Ma. I., PÉREZ, S. Y FUENTES, P.: La Hispania tardorromana y visigoda ..., pp. 146-147.

211 VAlverde CASTRO, Ma. R..: Ideología, simbolismo y ejercicio del poder real en la monarquía visigoda..., p. 157. Para mayores datos sobre la presencia de los imperiales en Hispania ver: VIZCAÍNO SÁNCHEZ, J.: "La presencia bizantina en "Hispania" (siglos VI-VII): la documentación arqueológica", Antigüedad y cristianismo: Monografias históricas sobre la Antigüedad tardía, 25, 2007, pp. 61 y ss y VALLEJO GIRVÉS, M.: Hispania y Bizancio: una relación desconocida, Madrid: Akal, 2012, en especial la p. 351.

212 ISID. Hist. Goth., p. 249.

${ }^{213}$ VALVERDE CASTRO, Ma. R.: Ideología, simbolismo y ejercicio del poder real en la monarquía visigoda ..., $\mathrm{p}$. 154. LORING, Ma. I., PÉREZ, S. Y FUENTES, P.: La Hispania tardorromana y visigoda ..., p. 258 y ss.
} 
enérgico carácter de este rey ${ }^{214}$, y cómo sometió al territorio ibérico a su voluntad. A través de estos escritos sabemos que en los años 569 y 570 Leovigildo coordinó sus tropas con el fin de atacar la zona controlada por los bizantinos ${ }^{215}$, logró recuperar la ciudad de Asidona (Medina Sidonia), pero no expulsar a los imperiales de la Península ${ }^{216}$. Al siguiente año ocupó la rebelde Córdoba, otras ciudades menores y castella independientes, aparentemente en el valle del Guadalquivir ${ }^{217}$, masacrando a una importante cantidad de rústicos ${ }^{218}$. En los sucesivos años, Leovigildo avanzó sobre los territorios de Sabaria ${ }^{219}$ (572), las regiones meridionales de Cantabria ${ }^{220}$, los montes Aregenses (donde tomó Aregia e hizo prisionero a Aspidio loci seniorem $)^{221}$. En sus últimas campañas, ya en el 576, Leovigildo sometió la región de la Orospeda ${ }^{222}$, organizó una expedición contra los pueblos del norte peninsular $(580)^{223}$ y atacó al reino suevo, destruyendo la entidad de aquel reino ${ }^{224}$. En este contexto se enfrentó a una flota franca destinada a auxiliar a los suevos, la cual terminó siendo derrotada, al igual que las tropas que se dirigieron hacia Carcasona y Nimes (585).

Gran parte de la historiografía, siguiendo las fuentes citadas, considera que los éxitos militares de Leovigildo instituyeron definitivamente las fronteras del reino ${ }^{225}$. Sin embargo, esta afirmación puede ser discutida, pues los documentos describen cómo los reyes sucesores continuaron destinando recursos para organizar operaciones militares contra los pueblos asentados en la Península que obstaculizaban el dominio total del territorio. Los enfrentamientos con los bizantinos también se desarrollaron en el año 589-590, durante los

${ }^{214}$ Isidoro exalta las empresas exitosas de Leovigildo, pero advierte que “...offuscauit in eo error impietatis gloriam tantae uirtutis", ISID. Hist. Goth., p. 254.

215 IOHAN BICL. Chr., p. 61 y 62.

${ }^{216}$ Ibidem, p. 63.

${ }^{217}$ Collins, R.: La España Visigoda 409-711 ..., p. 49.

${ }^{218}$ IOHAN BICL. Chr., p. 63. El término rústico será analizado más adelante.

219 Collins identifica la región de Sabaria y a sus habitantes los sappos en la zona circundante a la actual Salamanca, Collins, R.: La España Visigoda 409-711 ... p. 50. Díaz Martínez, por su parte, vincula esta región al río Sabor y a la comarca Sanabria, DÍAz MARTíneZ, P.C.: Hispania tardoantigua y visigoda ..., p. 359.

${ }^{220}$ La región de Cantabria del siglo VI abarcaba la costa de Vizcaya, una zona hacia el sureste, el alto el Ebro y partes de la Rioja. En Collins, R.: La España Visigoda 409-711 ..., p. 50.

${ }^{221}$ IOHAN BICL. Chr., p. 67.

222 IOHAN BICL. Chr., p. 69.

${ }^{223}$ Ibidem, p. 72.

${ }^{224}$ Ibidem, p. 75.

225 García Moreno es su mayor exponente. En sus obras se observa su admiración por este rey. Ver especialmente: GARCÍA MORENO, L.A.: Leovigildo: unidad y diversidad de un reinado, Madrid: Real Academia de Historia, 2008. 
reinados de Witerico (603-610), Gundemaro (610-612), Sisebuto (612-621) y Suintila (621631). En el transcurso de este último reinado se puso fin a la presencia de los imperiales en Hispania. De igual forma, los reyes godos se vieron obligados a organizar expediciones contra los astures, cántabros, y vascones, pueblos que acostumbraban a bajar desde sus moradas en las montañas hasta las tierras godas practicando el pillaje ${ }^{226}$. En las primeras décadas del siglo VIII ocurrieron las últimas campañas militares organizadas por los visigodos, que tuvieron como finalidad detener las avanzadas musulmanas que comenzaban a penetrar en la Península 227.

Al mismo tiempo que los reyes godos batallaban contra poblaciones ajenas a su dominio político que no se reconocían como parte del pueblo godo, debieron superar las rebeliones intra-aristocráticas ${ }^{228}$. Además, las elites locales también conservaron cierta independencia. La sumatoria de todas las contiendas creó un estado de conflicto casi continuo, dejando vulnerables las regiones hispanas a las consecuencias de las guerras; existen datos documentales que las ilustran.

El obispo Julián de Toledo narra varias de las operaciones bélicas del rey Wamba ${ }^{229}$. En el año 673 este rey junto a sus generales y su ejército entraron en la zona llamada Vasconia para combatir a sus habitantes. Durante siete días incendiaron campos y casas, apropiándose de los bienes muebles de los poblados saqueados; Wamba castigó a aquellos que durante la expedición incurrieron en el crimen de adulterio ${ }^{230}$. Esta breve caracterización de esta particular campaña ilumina cómo debieron ser todos los ataques a las regiones ocupadas por los pueblos libres del control godo. Los habitantes de las zonas atacadas muchas veces

\footnotetext{
${ }^{226}$ La mayoría de los reyes emprendieron campañas para someter al pueblo de los vascones, tal es el caso de Leovigildo, Recaredo, Gundemaro, Suintila, Chindasvinto, Wamba, Recesvitno y Rodrigo, del mismo modo hubo campañas contra los cántabros, las fortificaciones bizantinas al sur de la Península y contra los francos, en Montenegro, J. y del CAstillo, A: "Don Pelayo y los orígenes de la Reconquista: un nuevo punto de vista", Hispania, 180, 1992, pp. 5-32.

227 Ver: ARCE, J.: Esperando a los árabes: Los visigodos en Hispania (507-711), Madrid: Marcial Pons. Historia, 2011, pp. 283 y ss. Otra lectura sobre la conquista musulmana ver los argumentos centrales de DíAZ MARTíneZ, P. C. y POVEDA, P.: "Qui patrie excidium intulerunt. Hispania 711: explicaciones desesperadas para un colapso inesperado". Son muy acertadas las críticas que realizan a las distintas visiones historiográficas sobre este problema.

${ }^{228}$ Ver tabla con detalles en el capítulo. 4.

${ }^{229}$ IUL. TOL. $H W$.

${ }^{230}$ El obispo Julián describe al rey Wamba como un príncipe religioso. Ver sobre este tema la bibliografía citada en el capítulo 7 .
} 
formarían parte del botín (además de padecer la destrucción de sus bienes materiales, perder sus riquezas muebles y ser posibles víctimas de algún crimen o violencia sexual — dato que se desprende de la reprimenda del rey a sus comandados-). Isidoro de Sevilla cuenta que el rey Sisebuto, en su infinita bondad utilizó recursos propios para “(...) ut ultos ab exercitu suo hostili praeda in seruitutem redactos pretio dato absolueret eiusque thesaurus redemptio existeret captiuorum. (...)” en las expediciones por él comandadas contra los astures, los rucones y los bizantinos ${ }^{231}$. Tajón de Zaragoza recuerda que los vascos, bajo las órdenes de un godo de nombre Froia, devastaron su zona, y se llevaron consigo numerosos cautivos ${ }^{232}$.

Otros datos valiosos para comprender la problemática que aquí estamos tratando se encuentran en la obra de Julián, que describe los distintos momentos de la larga campaña del rey Wamba contra un grupo de aristócratas sediciosos ${ }^{233}$.

En unas de sus primeras acciones, el rey y sus tropas asaltaron una serie de castra (Caucoliber, Vulteraria y Castrum Libiae) ubicados en la espalda del monte Pirineo ${ }^{234}$. El paso siguiente se apoderó en etapas de varias ciudades, entre ellas Narbona, donde se encontraban los jefes del movimiento faccioso. Utilizaron la siguiente táctica para atacar a las distintas ciudades. Al amanecer, el ejército regio se agrupaba al pie de las murallas defensivas; a pesar de recibir todo tipo de proyectiles lanzados desde el interior, lograban entrar a las ciudades destruyendo el muro con continuos golpes e incendiando las puertas. Una vez dentro, se combatía cuerpo a cuerpo cruzando las espadas. Los daños a las ciudades y a sus habitantes no eran menores. El obispo Julián, queriendo enaltecer la figura de Wamba, detalla que luego de triunfar sobre la ciudad donde se ocultaba Paulo (el principal promotor de la rebelión) el rey godo ordenó dar sepultura a todos los caídos, reparar los muros, renovar las puertas, devolver las riquezas capturadas como botín a los habitantes y ayudar con fondos públicos a restaurar los daños materiales sufridos ${ }^{235}$.

\footnotetext{
${ }^{231}$ ISID. Hist. Goth., p. 275.

232 TAJ. Sent.p. 171. Sobre el autor ver: CODOÑER, C. (coord.).: La Hispania visigótica y mozárabe: dos épocas en su literatura, p. 196 y ss.

${ }^{233}$ Las implicancias sociopolíticas de este levantamiento aristocrático son analizadas en detalle en los capítulos siguientes.

${ }^{234}$ IUL. TOL. HW, p. 227: "Pirinei montis dorsa”.

${ }^{235}$ Ibidem, p. 240: "Sed post haec religiosi principis animus de reparatione inruptae urbis sollicitus statim murorum caua reformat, incensas portas renouat, insepultis tumulum praestat, incolis ablatam praedam restituens et exulcerata quaeque publico aerario fouens. ".
} 
La destrucción material, el pillaje, los robos, la violencia ejercida contra los pobladores de las zonas atacadas no fueron actos excepcionales registrados sólo en las campañas de Wamba o de Sisebuto. Los reyes debieron legislar sobre los posibles abusos de los soldados durante las expediciones militares, lo cual da cuenta de la frecuencia de estas acciones. En las leyes 8, 1, $8^{236}$ y 8, 1, $9^{237}$ se dictaminó que cualquier persona en servicio de armas que en una expedición de carácter público perpetrase cualquier crimen, acto ilícito o robo sería penado de acuerdo a lo establecido en las leyes según la naturaleza del caso; aquellos implicados en hurto deberían restituir el valor del bien o devolver lo extraído y sería castigado con cincuenta latigazos, si se tratase de un siervo que hubiera actuado sin consentimiento de su dueño recibiría doscientos.

Durante las campañas militares, los expedicionarios eran los sujetos perpetradores de los crímenes, mas también fueron víctimas del pillaje; así lo señalan las leyes $9,2,2^{238}$ y 8 , $1,7^{239}$ elaboradas con el fin de proteger la propiedad y los bienes de aquellos que se encontraran fuera de sus hogares a causa de una campaña militar pública.

Las guerras no fueron el único problema secular del reino: las pestes y las plagas de insectos también afectaron seriamente a la población y a los recursos productivos.

García Moreno explica que la Península Ibérica ha sido afectada por el pequeño pero significativo cambio de temperatura que experimentó Europa occidental durante el siglo VII $^{240}$. Hubo desbordes de ríos (el Guadiana en el año 631 saliendo de su cauce inundó considerables extensiones de tierra cultivada y derrumbó varios edificios ${ }^{241}$ ) y años de continuas sequías, tantos que el autor de las VSPE recuerda que cada vez que la lluvia faltaba, y una larga sequía azotaba a la tierra con un calor excesivo, los pobladores recurrían al obispo Inocencio para que mediante sus rezos el cielo concediera el agua necesaria ${ }^{242}$. Este cambio climático agravó la situación de Hispania, ya propensa por sus microclimas a la falta de lluvias. Una de las consecuencias más graves de las sequías son las langostas que atacan las

\footnotetext{
${ }^{236} L V$, p. 316.

${ }^{237}$ Ibidem, p. 316 y 317.

${ }^{238}$ Ibidem, p. 367.

${ }^{239}$ Ibidem, p. 316.

${ }^{240}$ Se inició una era más cálida y seca dejando atrás a una más húmeda. GARCÍA MorenO, L.A.: Historia de España visigoda..., p. 219.

${ }^{241}$ VSPE, p. 20.

${ }^{242}$ Ibidem, p. 99.
} 
$\operatorname{cosechas}^{243}$. Variados tipos de fuentes registran las consecuencias catastróficas que estos insectos dejaban a su paso: Gregorio de Tours relata cómo la plaga de langostas azotó a la provincia Cartaginense desde el 578 o 579, atacando por lo menos cinco años, "hasta el extremo de que no quedaba árbol, ni viña, ni hierba verde que no hubieran sido destruidos"244; Chindasvinto se vio obligado a promulgar una ley que permitía el adelanto de la recolección de las cosechas con el fin de salvar algo de la amenaza de estos fitófagos ${ }^{245}$. García Moreno apunta que las sequías y las plagas trajeron aparejadas hambrunas generalizadas; el hambre quedó evidenciada, según este autor, para el último tercio del siglo VI, para mediados del siglo VII, durante los años 80 del siglo VII y para la primera década del siglo VIII ${ }^{246}$.

Otra calamidad natural que por ciclos afectaba a las regiones hispanas fueron las pestes; los autores especializados aseguran que el índice de mortandad de estas ha sido de un cincuenta por ciento, brindando una imagen de las crudas secuelas sobre la población. El ciclo endémico de las pestes está ampliamente documentado: el Chroniconrum Caesaravgvstanorum anuncia que en el año 542 "His diebus inguinalis plaga totam paene contrivit Hispaniam" 247; Juan de Bíclaro registró la peste inguinal para el año 572 248 ; diez años más tarde se propagaba por la Galia Narbonense y por los puertos del Levante hispano en el año 588 249 ; la Crónica Mozárabe evocaba el flagelo que causó la peste durante el reinado de Égica ${ }^{250}$, con tan graves consecuencias que este rey en el decimoséptimo Concilio de Toledo (año 694) decretó que los judíos de la Galia quedasen exentos de las medidas punitivas adoptadas porque la tierra se estaba despoblando ("ut quia delictis ingruentibus et

\footnotetext{
${ }^{243}$ GARcía Moreno, L.A.: Historia de España visigoda..., p. 220. Cuando los reservorios de pastos de los nichos ecológicos de las langostas se agotan por la falta de agua, estos insectos salen en su fase gregaria en busca de alimento, convirtiéndose en enjambres incontenibles.

${ }^{244}$ Citado en ORLandis, J.: Historia del Reino visigodo español..., p. 215.

${ }^{245}$ LV 12, 1, 2, p. 407.

${ }^{246}$ GARCÍA MORENO, L.A.: "El campesinado hispanovisigodo entre bajos rendimientos y catástrofes naturales. Su incidencia demográfica". GARCÍA MoRENO, L.A.: Historia de España visigoda..., p 221. Las fuentes que atestiguan las hambrunas son: la Vida de San Audonio y el Abjar Machmuâ. Citados por ORLANDIS, J.: Historia del Reino visigodo español..., p. 215.

${ }^{247}$ Chron.Caesarag. pp. 222-223. En esta crónica se asientan sucesos ocurridos entre los años 450 y 568 , sin entrar en demasiados detalles.

${ }^{248}$ IOHAN BICL. Chr., p. 65.

${ }^{249}$ GREG. TUR. Hist. Franc., p. 442.

${ }^{250}$ Chronica muzarabica anni 754, p. 59.
} 
externae gentis incursu el plagae inguinalis interitu pars ipsa ab hominibus desolata dinoscitur") ${ }^{251}$.

El decreto de Égica recién citado es de lo más interesante. Enumera tres factores que devastaron a la Galia, de los cuales dos han sido recién estudiados (las consecuencias de las guerras y de las pestes). Los delitos relacionados con el bandidaje, fenómeno regular extendido por todo el reino, constituye un tercer factor responsable de la desastrosa situación. Lo analizaremos dentro del contexto de crisis de dominación y subordinación de la mano de obra.

\section{Explotación de la mano de obra}

Una parte de la fuerza del trabajo campesino ha sido subordinada por la aristocracia; sin embargo, como sostiene un importante sector de la historiografía, la forma predominante que adquirió la explotación no fue la esclavitud ${ }^{252}$, sino las diversas situaciones intermedias de dependencia. Los autores coinciden en señalar que durante los siglos VII y VIII el estatus de libre constituía más una diferencia jurídica que una diferencia material. Los campesinos dependientes estaban obligados a entregar parte de su producción a la aristocracia y/o al estado (que la absorbería en forma de tributo ${ }^{253}$ ); otro grueso sector organizaba de forma autónoma la gestión de la tierra, adquiriendo de forma progresiva una independencia económica y política. Damián Fernández, para el caso visigodo, sostiene que

"La mano de obra rural estaría caracterizada por relaciones contractuales de diversa índole, donde el status social pasaría a un segundo plano frente a las regulaciones respecto al uso de tierra, renta, y obligaciones mutuas."254

La naturaleza limitada de las fuentes complica el análisis sobre estos problemas, y la complejidad de cada región hace que sea difícil trazar un cuadro general de la situación visigoda; aunque afirmamos que tanto los campesinos, que mantuvieron una relación con los

\footnotetext{
251 “(...) ut quia delictis ingruentibus et externae gentis incursu et plagae inguinalis interitu pars ipsa ab hominibus desolata dinoscitur (...)", Concilios, Toledo XVII, año 694, discurso de apertura, p. 525.

${ }^{252}$ MARTín VISO, I.: "Hispania en el periodo postromano (siglos V-VIII)", p. 40.

${ }^{253}$ Idem.

${ }^{254}$ FERNÁNDEZ, D.: "Desigualdad económica, propiedad rural y cultura material en la Antigüedad Tardía. El caso de la Península Ibérica (siglos IV-VII)”, p. 187.
} 
poderosos bajo los términos del patrocinio, como los esclavos no formaron un cuerpo de trabajadores dóciles. Al contrario, se opusieron a la aristocracia y tomaban las oportunidades que se les presentaban para mejorar sus condiciones e insertarse en las comunidades de los campesinos autónomos. Y esto sí que lo podemos rastrear en los documentos.

Astarita demuestra para el periodo visigodo la existencia de una crisis de poder, un creciente conflicto social y una relajación en la explotación de la mano de obra ${ }^{255}$; el análisis sobre el cuerpo legislativo, tanto secular como eclesiástico, le permite concluir que los servi (campesinos sometidos a tributos) y los esclavos de tipo antiguo que debían respeto y servicio a los obispos, reyes y magnates constituían, en realidad, una fuerza laboral indócil.

Siguiendo esta línea de investigación, examinaremos la documentación goda con el objetivo de estudiar el comportamiento insubordinado de los trabajadores dependientes que escapaban de sus dueños y de aquellos que cometían actos de violencia física y/o verbal, y su efecto sobre la producción agraria, una de las bases del dominio económico de la aristocracia.

En relación con los esclavos desertores, uno de los documentos más importantes es la ley promulgada por Égica en el decimosexto año de su reinado (año 702) destinada a endurecer las penas sobre aquellos que daban cobijo a los fugitivos. Esta ley de fin del ciclo visigodo engrosaba al conjunto de otras veintiuna sobre los fugitivos, la mayoría antiquae ${ }^{256}$. Sin embargo, la norma de Égica es la más esclarecedora de todas para tratar el problema de la explotación de la mano de obra.

En el preámbulo, se denunció que con el creciente número de esclavos que huyeron de sus amos “(...) ita ut non sit penitus civitas, castellum, vicus aut villa vel diversorium, in quibus mancipia latere minime dignoscantur" 257 . Cabe dentro de las posibilidades plantear que la desmesura contenida en la ley citada se correspondía con la estridencia propia de la retórica tardorromana que caracterizó a los escritos jurídicos godos, como sostiene

\footnotetext{
255 AstARITA, C.: “Construcción histórica y construcción historiográfica de la temprana Edad Media".

${ }^{256}$ Para un análisis de las disposiciones legales sobre los siervos fugitivos ver: ISLA FrEZ, A.: "Los fugitivos y el título sobre ellos del Liber Iudicum", Arqueología y territorio medieval 8, 2001. POVEDA ARIAS, P.: "Relectura de la supuesta crisis del fin del reino visigodo de Toledo, una aproximación al reinado de Egica a través de sus fuentes legales", Anuario de historia del derecho español, 85, 2015, p. 39.

${ }^{257}$ LV 9, 1, 21. pp. 363 y 364. GARCÍA LÓPEZ, Y.: Estudios críticos y literarios de la "Lex Wisigothorum", Universidad de Alcalá, 1996, pp. 579-587.
} 
Wickham ${ }^{258}$ y convalida Poveda ${ }^{259}$. Sin embargo, el historiador inglés reconoce que la finalidad de dicha ley fue controlar la movilidad rural de los dependientes no libres ${ }^{260}$. Asimismo, Poveda advierte que el término fugitivo se aplicaría a aquellos que abandonasen a sus patrones, es decir, tanto esclavos de tipo antiguo como campesinos libres dependientes. Isla Frez ya había advertido que la ley egicana tuvo como objetivo aumentar el castigo sobre el fenómeno de los fugitivos e instar a las autoridades locales a salir de su estatismo para actuar en consecuencia ${ }^{261}$. Isla Frez concluyó que el campesinado tuvo distintas situaciones jurídicas $^{262}$.

Otros datos documentales contemporáneos avalan que la fuga de esclavos ha sido un fenómeno de larga data ${ }^{263}$. Uno de ellos aparece en la hagiografía de San Fructuoso de Braga $^{264}$.

${ }^{258}$ WiCKHAM, C.: Una historia nueva de la Alta Edad Media..., p. 165.

${ }^{259}$ POVEDA ARIAS, P.: "Relectura de la supuesta crisis del fin del reino visigodo de Toledo, una aproximación al reinado de Egica a través de sus fuentes legales". p. 40.

${ }^{260}$ WickHAM, C.: Una historia nueva de la Alta Edad Media..., p, p. 745.

${ }^{261}$ ISLA FrEZ, A.: "Los fugitivos y el título sobre ellos del Liber Iudicum” ... p. 120. Esta ley fue vista como un síntoma de la debilidad del reino visigodo: THOMPSON, E.A.: The goths in Spain, p. 323 y p. 362 KING, P.D.: Derecho y sociedad en el reino visigodo, pp. 40- 41; PÉREZ SÁNCHEZ, D.: "Legislación y dependencia en la España visigoda", <Romanización $>$ y <reconquista $>$ en la Península Ibérica: nuevas perspectivas, 1998, p. 228. Un punto de vista distinto: POVEDA ARIAS, P.: "Relectura de la supuesta crisis del fin del reino visigodo de Toledo, una aproximación al reinado de Egica a través de sus fuentes legales”. p. 39). Poveda sostiene que esta ley fue un intento de Égica de fortalecer su gobierno demostrando su capacidad de legislación. Ibidem, pp.39-40.

${ }^{262}$ ISLA FreZ, A.: "Los fugitivos y el título sobre ellos del Liber Iudicum” ... pp. 118-119. En relación con el problema del estatus jurídico de los trabajadores rurales ver: GARCíA MoRENO, L. A.: "From coloni to servi. A History of the Peasantry in Visigothic Spain”, Klio. Beiträge zur alten Geschichte, vol. 83, 2001, p. 198-212. Castellanos, S.: Poder social, aristocracias y "hombre santo" en la Hispania visigoda: la "vita aemiliani" de Braulio de Zaragoza, Logroño: Universidad de La Rioja, 1998. DíAz MARTíneZ, P.C.: "El testamento de Vicente: Propietarios y dependientes en la Hispania del s. VI", <Romanización $>y<$ reconquista $>$ en la Península Ibérica: nuevas perspectivas, 1998, pp.257-270.

${ }^{263}$ Pablo Sarachu afirmó lo mismo para el reino burgundio. Este paralelismo abre las puertas a la comparación. SARACHU, P.: Patronazgo rural, dependencia y sociedad de base campesina en la Galia meridional (c. 400-c. 550), (Tesis de posgrado). -- Presentada en Universidad Nacional de La Plata. Facultad de Humanidades y Ciencias de la Educación para optar al grado de Doctor en Historia, 2015. Disponible en: http://www.memoria.fahce.unlp.edu.ar/tesis/te.1176/te.1176.pdf

SARACHU, P.: "Esclavos sin esclavismo: la inestabilidad de la explotación servil en el reino Burgundio", Circe, XV, 2011, pp. 159-173.

${ }^{264}$ Hasta mediados del siglo XX, la hagiografía de San Fructuoso de Braga ( $†$ 665) era atribuida a Valerio del Bierzo, santo visigodo que vivió en el siglo VII. M. C Díaz y Díaz sostiene que la Vita Fructuosi llegó a manos de Valerio antes de que este escriba sus obras; por lo tanto, se infiere que esta pieza fue escrita o a fines del 
En su viaje con destino a Mérida, Fructuoso transitaba la región de Egitania cuando decidió descansar bajo una arboleda. Mientras se encontraba tendido bajo la sombra, un rústico, percibiéndolo solo, en medio del bosque, con vestidos vulgares y con los pies descalzos, lo confundió con un fugitivo. El ataque comenzó con insultos mientras que Fructuoso repetía una y otra vez: "Plane fugitivus non sum" 265 , mas como el campesino no quedó satisfecho sólo con eso, lo golpeó repetidamente. Fructuoso se liberó de su agresor por intervención divina. La escena hagiográfica descripta no debió resultar extraña para el público de la época, pues el anónimo autor utilizó un hecho cotidiano (la presencia de esclavos fugitivos) para darle credibilidad a la ayuda divina recibida por el santo en su feroz ataque. Orlandis no dudó en afirmar que el pasaje hagiográfico descrito es “(...) un exponente de la psicosis colectiva que existía ya en torno a los siervos huidos (...)"266; aunque el relato también pudo estar dirigido a fomentar en la población un sentimiento negativo hacia los fugitivos, que no tenemos por qué asumir como real. Al contrario, las leyes regulaban los castigos dirigidos a los pobladores que refugiasen a siervos huidos, lo que demostraría una actitud habitual.

Los datos documentales sobre el problema proporcionan una dimensión del fenómeno de la fuga de la mano de obra dependiente que también afectó a la productividad de las tierras eclesiásticas, como se evidencia en ciertos cánones conciliares.

Los obispos visigodos realizaron denuncias con el objetivo de frenar los abusos perpetrados por los superiores sobre ciertos miembros de la Iglesia que eran explotados como dependientes. Es así como en el año 572 se advertía a los obispos que no tratasen a los clérigos como esclavos ${ }^{267}$, mientras que el canon XX del Concilio de Toledo III del año 589 obligaba al metropolitano a sancionar a los obispos que imponían al clero de su jurisdicción prestaciones personales y exacciones extraordinarias propias de sujetos sometidos a una relación de explotación ${ }^{268}$; en el año 633 se exigió a los obispos que dejasen de tratar a los miembros de los monasterios como siervos trabajadores de una possessio ${ }^{269}$. En el año 675

siglo VI o en las primeras décadas del VII. DÍAZ Y DÌAZ, M.C.: Valerio del Bierzo. Su persona. Su obra..., p. 125.

265 Vit. Fruct, p. 98.

${ }^{266}$ ORLANDIS, J.: Historia del reino visigodo español... p. 223.

${ }^{267}$ Concilios, Braga II, año 572, c. II, p. 81.

268 Concilios, Toledo III, año 589, c. XXI, p. 132.

${ }^{269}$ Ibidem, Toledo IV, año 633, c. LI, p. 208-209. 
se volvió a instar a los obispos para que no empleasen a los siervos de la Iglesia en sus propiedades personales, para así evitar el descuido del laboreo de los bienes eclesiásticos ${ }^{270}$.

De estas noticias inferimos que los obispos pretendían que los miembros de sus iglesias de rangos inferiores bajo sujeción política (clérigos, presbíteros, diáconos, subdiáconos o monjes) se comportasen como trabajadores productivos en sus dominios, suplantando a los esclavos faltantes ${ }^{271}$; lo que atestigua la debilidad de las relaciones de explotación.

La falta de mano de obra servil también afectó a los laicos, supuesto que se desprende de la noticia que brinda el canon XXI del tercer Concilio de Toledo, en el que los obispos pidieron que no les esté permitido a los "iudicibus vel auctoribus publicis" 272 molestar a los siervos de la Iglesia o de algún clérigo con prestaciones personales.

Al mismo tiempo que las autoridades de la Iglesia intentaban limitar las prácticas abusivas contra sus correligionarios, promulgaron otros cánones donde solicitaron que el clérigo que huyera de su iglesia de origen sea inmediatamente devuelto con todas las

${ }^{270}$ Ibidem, Braga II, año 572, c. VIII, p. 377-378.

${ }^{271}$ Otro indicio sobre el celo de la Iglesia de cuidar a la mano de obra disponible lo constituye las anulaciones de las manumisiones dadas por algunos obispos en sus testamentos o lechos de muerte decididas en Concilio, como los casos de Gaudencio y Ricimiro. En el caso del obispo Gaudencio de Sevilla (año 590), el sucesor de este pidió que los siervos liberados por aquel permaneciesen bajo el dominio de la iglesia y que su peculio solo pueda ser donado a sus hijos o a la iglesia (Ibidem, Concilio de Sevilla II, año 590, p. 151). En el año 656, reunidos los obispos en el Concilio de Toledo X decidieron que el obispo Fructuoso confirmase o revocase la libertad dada a los siervos de la Iglesia de Dumio (unos quinientos esclavos) concedida en el testamento del fallecido obispo Ricimiro de dicha Iglesia, observando los daños causados a los bienes eclesiásticos (Ibidem, Toledo X, año 656, c. p. 322-324).

No solo anulando las manumisiones la Iglesia procuró cuidar la mano de obra disponible, también implementó fuertemente una manumisión limitada. El Concilio de Toledo IV en una serie de cánones (LXVII a LXXIV) reguló cómo debía efectuarse la manumisión de los siervos de la Iglesia: por cada siervo manumitido el obispo debería ofrecer dos del mismo valor delante del Concilio; el liberto no podía acusar o testificar contra la Iglesia a la cual perteneció bajo pena de volver a la servidumbre. Asimismo, los libertos de la Iglesia no abandonarían el patrocinio de esta porque "quia nunquam moritur eorum patrona", y presentarían servicio y obediencia; aquel que no cumplía con estas disposiciones se le anulaba su manumisión Ibidem, p. 214-216. En el mismo sentido, cánones IX y X del Concilio de Toledo VI, p. 240; cánones XI a XVI del Concilio de Toledo IX Ibidem, p. 303-305; canon XX del Concilio de Mérida, Ibidem, p. 339-340. García Moreno sostiene que el celo de la Iglesia para conservar a sus manumitidos in obsequio se explica “(...) porque de este modo seguirían trabajando las mismas parcelas que antes venían haciéndolo como esclavos, y que si no permanecerían improductivas y por tanto sin rentar", GARCÍA MORENO, L.A.: "Composición y estructura de la fuerza de trabajo humana en la Península Ibérica durante la Antigüedad Tardía", Memorias de Historia Antigua, Oviedo, 1977, p. 248. Ver también ASTARITA, C.: "Construcción histórica y construcción historiográfica de la temprana Edad Media”, pp. 257-258.

${ }^{272}$ Concilios, Toledo III, año 589, c. XXI, p. 132. 
posesiones que podría obtener de aquel de quien se fugó ${ }^{273} \mathrm{y}$, además, reclamaron que los clérigos que desde niños fueron educados en sus iglesias quedasen adscriptos a las mismas como compensación por la instrucción recibida ${ }^{274}$. La presencia de clérigos y monjes que transitaban por los caminos sin obedecer a ningún tipo de autoridad eclesiástica fue un hecho muy común, como lo refleja la normativa eclesiástica ${ }^{275}$. Pero no sólo se ha transmitido este fenómeno por medio de las ordenanzas. Afortunadamente, sobrevivió un ejemplo de la práctica acusatoria que efectivamente realizaban los obispos y los abades sobre los monjes errabundos, y el pedido de su detención. Se trata de una misiva escrita por el cenobita Mauricio y dirigida al obispo Agapio, de sede sin identificar, por medio de la cual se defendió de la imputación de ser vagabundo y prófugo ${ }^{276}$, atribuyendo tales mentiras a las puras habladurías de hombres de gran vileza.

Todos los cánones que denunciaron la fuga de clérigos solicitaban que los obispos que los acogieron los retornasen y no los recibiesen como si fueran suyos; de no cumplir enfrentarían severas penas, entre ellas la excomunión ${ }^{277}$, no participar en la asamblea eclesiástica $^{278}$ y la penitencia por largas jornadas. Esta serie de disposiciones nos permite plantear que ante la falta de mano de obra dependiente las distintas jurisdicciones episcopales competían entre sí por los sujetos adscriptos a las iglesias.

Además de la insubordinación plasmada en la fuga, los trabajadores dependientes mostraban actitudes malintencionadas para con sus amos. Las protestas y amonestaciones efectuadas por los obispos en reiteradas ocasiones pueden considerarse prueba de ello. En el año 619 Eliseo, un siervo de la iglesia de Cabra a quien se le había concedido la libertad, tuvo la intención de envenenar al obispo de dicha iglesia y causó daños materiales a la misma $^{279}$. Años más tarde algunos eclesiásticos atribuían sus males y/o enfermedades a

\footnotetext{
273 Ibidem, Toledo XIII, año 683, c. XI, p. 429. Otros cánones donde se pide que los obispos devuelvan a los clérigos fugados: Braga II, año572, c. XXXIII, p. 95; Sevilla II, año 590, c. III, p. 164.

${ }^{274}$ Ibidem, Toledo II, año 527, c. II, p. 43.

275 Ibidem, Toledo IV, año 633, cánones LII y LIII, p. 209; Toledo VI, c. VI, año 638, p. 238; Toledo VII, año 646, c. V, p. 255; Toledo XIII, año 683, c. XI, p. 429 y ss.

${ }^{276}$ Ep. Wis., pp. 45-47 (n $\left.{ }^{\circ} \mathrm{XVI}\right)$. Sobre la difícil lectura del latín de las cartas visigodas ver: MARTÍN IGLESIAS, J.C.: "El latín de las Epistulae Wisigothicae", Cuadernos de Filología Clásica. Estudios Latinos, 34, 2014, pp. 37-60.

277 Concilios, Sevilla II, año 619, c. III, p. 164.

278 Ibidem, Braga II, año 572, c. XXXIV, p. 96.

${ }^{279}$ Concilios, Sevilla II, año 619, c. VIII, p. 168.
} 
maleficios realizados por sus siervos ${ }^{280}$. En los Concilios se registraron solo amenazas efectuadas contra los miembros de las distintas iglesias peninsulares, en algunas hagiografías, en cambio, se describieron hechos de violencia de mayor proporción. El capítulo tercero de las $V S P E^{281}$ narra la llegada del abad católico Nancto a la provincia lusitana. Pasado un corto tiempo desde su arribo, sus numerosas virtudes se difundieron tanto que el rey Leovigildo, a pesar de su arrianismo, le concedió la escritura de potestad de una importante posesión fiscal (eidem uiro auctoritate conscripta de quodam precipuo loco fisci direxit) ${ }^{282}$ con el propósito de que Nancto rogase por él en sus oraciones. Intrigados los habitantes de esas tierras decidieron conocer al sujeto que era su dominus noster. Al llegar la sorpresa y la decepción los embargó cuando se encontraron con un hombre de aspecto vulgar ("eum veste sordidum crine deformem" ${ }^{283}$ ) y comentaron entre ellos "Melius est nobis mori quam tali domino servire"284. Después de unos días, estando Nancto solo en el bosque junto a sus ovejas, los habitantes pusieron fin a su vida rompiéndole el cuello. Este pasaje revela que ante la presunción de los hombres sobre la incapacidad de su dominus de cumplir con su papel de protector no vacilaron en romper la relación de dependencia de la manera más brutal.

El episodio de Nancto no es un hecho aislado. En los escritos de Valerio del Bierzo existe una noticia de similar característica. Este santo describió el trágico final de Juan, discípulo suyo y presbítero de un monasterio ${ }^{285}$ : estando este religioso postrado ante el altar, un rusticus de forma cruel e impía lo degolló. Al obispo Justo, de sede desconocida, le deparó un destino similar. Cuenta Idelfonso de Toledo que el obispo de conducta inmoral murió estrangulado mientras dormía a manos de sus propios ministris altaris ${ }^{286}$. Estos hechos demuestran lo habitual de la violencia física para finalizar una relación de dominio insatisfactorio para los dependientes ${ }^{287}$. Las posibilidades de romper los vínculos de dependencia serán analizadas en detalle en el capítulo cinco. Aquí resaltamos la violencia abierta ejercida hacia un sector de la sociedad.

\footnotetext{
${ }^{280}$ Ibidem, Mérida, año 666, c. XV, p. 336.

${ }^{281}$ VSPE, p. 23.

${ }^{282}$ Idem.

${ }^{283}$ Idem.

${ }^{284}$ Idem.

285 VAL. Replic., p. 295.

${ }^{286}$ ILD. ToL. De vir. Illustr., p. 112 “(...) sed tabefactus et in reprobrum uersus sensum, ob intemperantiam morum a nisistris altaris sui dormiens strangulatus laqueo expirauit.".

${ }^{287}$ MARTIN, C. : La géographie du pouvoir dans l'Espagne visigothique... p. 123.
} 
El mal comportamiento de los siervos era castigado por los amos con severas penas, tan brutales que la misma Iglesia quiso mitigarlas. El canon XV del Concilio de Mérida del año 666 prohibió a cualquier autoridad episcopal arrancar o cortar los miembros del cuerpo de algún siervo de la Iglesia ${ }^{288}$; en el año 675, en la celebración del Concilio de Toledo XI, se promulgó que los obispos no se involucrasen en los juicios de sangre ni apoyasen la mutilación de cualquier persona como castigo. Podemos pensar que estas últimas normas analizadas contribuyeron objetivamente a preservar la mano de obra disponible que, como hemos visto, era escasa o rebelde.

Es innegable que los escritos visigodos documentan la continuidad de las relaciones de explotación. Algunos ejemplos de lo dicho son los testamentos citados más arriba, las leyes que regulan el trabajo de los esclavos y siervos, y los castigos penales diferenciados de acuerdo con el estatus jurídico de la persona.

Sin embargo, metodológicamente desde esta investigación intentamos destacar que la sujeción y explotación de la mano de obra servil (ya fuesen esclavos de tipo antiguo o campesinos sujetos a obligaciones) no fue tarea sencilla. La exploración de las fuentes sin relaciones de filiación directa constata que la indocilidad de la mano de obra ha sido consecuencia de la crisis del sistema de dominación y explotación. El carácter transitivo del reino visigodo permitiría este mosaico de diversas situaciones de explotación.

Luego de observar que la fuga de esclavos fue un fenómeno regular, resulta significativo indagar sobre los mecanismos que adoptaron estos prófugos de la ley para conseguir su sustento. Además de descubrir el destino de los huidos, observaremos una variable más del conflictivo escenario en el cual estaba obligada a actuar la realeza.

Como primeras alternativas posibles los fugitivos se refugiarían en alguna aldea bajo la protección de los habitantes de esta ${ }^{289}$ o servirían a otro patrón (como se denunció en los cánones eclesiásticos); en uno u otro caso estos siervos se emplearían en trabajos rurales. Sin embargo, otra opción para el fugado habría sido integrarse a alguna banda criminal, o formar

\footnotetext{
${ }^{288}$ Concilios, Mérida, año 666, c. XV, p. 335; Toledo XI, año 675, c. VI, p. 360.

${ }^{289}$ La ley de Égica ya citada castiga con doscientos latigazos a aquellos que escondan a siervos fugitivos, sin distinción alguna de estatus “(...) tam viri quam femine, cuiuslibet sint gentis, generis, ordinis vel honoris (...)”, $L V$, p. 364. La imposición de este castigo evidencia que comúnmente los pobladores daban refugio a fugitivos
} 
una, y basar su economía en el pillaje ${ }^{290}$, el secuestro de rehenes ${ }^{291}$ y el robo en los $\operatorname{caminos}^{292}$. Los hombres de letras de los siglos V-VIII denunciaron sobre las acciones de las bandas de ladrones y los robos que sufrían los transeúntes; ya sea en las epístolas, las crónicas, las hagiografías o inclusive en las leyes ${ }^{293}$ y los cánones conciliares, los hechos criminales referidos fueron siempre circunstanciales al relato principal, lo cual nos hace descartar que se tratase de un tópico literario.

Los autores que investigaron el bandidaje en Hispania - ya sea de forma secundaria o como objeto principal - coincidieron en afirmar que ha sido un fenómeno social que, lejos de limitarse a una u otra zona aislada, se había generalizado por todo el reino visigodo. Collins y Pérez Sánchez asocian la expansión de las bandas que se dedicaron al latrocinio a los desórdenes que dejó el cambio socioeconómico producido por la disolución del Bajo Imperio $^{294}$. Por su parte, Díaz Martínez considera que el bandidaje, muy distinto al robo circunstancial producto de la desesperación y la miseria, "representa una alternativa de

${ }^{290}$ Casos ilustrativos de pillaje se encuentran en la Vita Sancti Aemiliani y en la autobiografía de Valerio del Bierzo. En el primero de estos escritos se detalla cómo unos sujetos de nombres Sempronio y Toribio roban el caballo en el cual Emiliano se transportaba hasta la iglesia, en BRAU. VSE., p. 209. Valerio relata que un personaje de cuna ilustre llamado Basiliano le otorgó dos bestias de labor agrícola. El prepósito del monasterio donde Valerio pasaba sus días, con aires de venganza, mandó a unos sujetos de su casa natal a robar los mulos; sin embargo, su plan falló pues no pudieron llevarse a los animales. Los ladrones cuando regresaron a sus tierras encontraron que una fuerte granizada había arruinado gran parte de la cosecha y su mal se agravó cuando unos bandidos venidos de otra parte les sustrajeron todos los bueyes, que nunca más pudieron recuperar; esta situación dejó "sola illis dominis et seruis famis et miseria mansit", VAL. Ord., p. 274.

${ }^{291}$ Díaz Martínez analizó la referencia hecha en la Regula communis IX sobre la importancia de cuidar a los rebaños porque con esos recursos "inde redimuntur captiui". Finalizado el estudio sobre la regla citada y otros documentos contemporáneos, concluyó que el rapto de personas y la liberación de estas, luego de recibir un pago en concepto de rescate, era una actividad corriente de los grupos de bandidos. DíAz MARTínez, P. C.: "Redimuntur captiui. A propósito de Regula Communis IX", Gerión. Revista de Historia Antigua, vol. 10, 1992.

${ }^{292}$ El robo en los caminos a los viajeros y transeúntes debió de ser un fenómeno bien extendido. La primera prueba de esto es la ley 7, 2, 17 "De male tractatis et indebite contractis rebús, et ut tantum de illa re conpositio fiat, que fuerit ablata", $L V$ p. 295, introducida al código penal por Recevinto y confirmada por Ervigio, donde se castigó el robo del equipaje, la ropa o el daño físico provocado en un camino. La confirmación más contundente del fenómeno se halla en una carta escrita por Braulio de Zaragoza (†651) al obispo Valentín. En esta ocasión el santo le relató a su destinatario que el nivel de inseguridad era tan alto que los hombres no se atrevían a marchar por la región zaragozana y sus alrededores a causa de los ladrones (“... quoniam regiones nostre homines pergeret illi pauent latrones”), BRAU. Ep., epístola XXIV, p. 120. Ruth Miguel Franco la enumera como la carta número 15 .

${ }^{293} L V, 9,1,19$.

${ }^{294}$ COLlins, R.: La España Visigoda 409-711 ..., p. 49. PÉREZ SÁnCHEZ, D.: "Problemas sociales en el reino visigodo de Toledo". 
poder"295; las bandas en las localidades donde actuaban recibían el apoyo de los sectores sociales más bajos a los cuales protegían de la actuación de la aristocracia central o comarcal. Las bandas más organizadas, además de cometer delitos menores, robaban en las grandes propiedades, saqueaban ciudades e incluso se enfrentaron a ejércitos profesionales (esto último por lo menos en el siglo $\mathrm{V})^{296}$.

Un punto interesante que se desprende de este análisis es que los siervos fugitivos que se convirtieron en bandidos abandonaban las actividades productivas. Esto significó que cierto número de siervos quedó fuera de la órbita de la producción y del control; en otras palabras, un segmento del conjunto de la fuerza de trabajo se perdió en los intersticios del sistema, agravando la falta de trabajadores en las tierras de los magnates. Asimismo, la expansión de las bandas criminales acrecentaba la difícil situación de la producción agraria, principalmente porque los frutos y los animales eran tomados como botín y por el bloqueo a los caminos, consiguientemente al comercio.

Tanto la proliferación de estos grupos de salteadores y su éxito para controlar extensas áreas del reino - hasta llegar a dejar zonas aisladas $\mathrm{y}$, por lo tanto, desarticulando al territorio - y las dificultades del control de la mano de obra sólo podrían ser comprendidas como evidencia de la mermada capacidad política tanto del poder central como de las aristocracias locales. Además, esta disgregación de las estructuras económicas de la Península Ibérica vista en los textos coincide con el registro material, tal como lo demostró Wickham en su análisis sobre las redes de intercambios, oportunamente considerado ${ }^{297}$.

\section{2}

\section{Las bases materiales del poder regio}

Las páginas que siguen las dedicaremos a estudiar el origen de los recursos económicos de los reyes de Toledo analizando las distintas formas de explotación. En un primer momento, observaremos las vías "tradicionales" de enriquecimiento: el sistema fiscal y la gestión de las posesiones de tierras; luego, se procederá al examen de otras vías: las

\footnotetext{
${ }^{295}$ DíAz MARTínez, P.C.: Hispania tardoantigua y visigoda ..., p. 329.

${ }^{296}$ Collins, R.: La España Visigoda 409-711 ..., p.22.

${ }^{297}$ Ver capítulo. 1.
} 
multas y castigos judiciales, las formas de explotación externa y la incautación de bienes. El fin último de este apartado es ponderar la disponibilidad de recursos por parte de los reyes para hacer frente tanto a la administración del reino como para satisfacer las demandas de sus clientelas y de la aristocracia adepta.

(I) Vias de enriquecimiento de los reyes godos: recaudación fiscal y explotación de las posesiones

La documentación referente a la recaudación de impuestos en la época goda es poco abundante; sin embargo, varios de los autores investigan el tema en profundidad.

Valverde Castro analiza la teoría política que justificaba los derechos de los reyes de controlar e intervenir en el sistema fiscal ${ }^{298}$. Luego de razonar sobre los cánones conciliares que trataron asuntos de naturaleza impositiva ${ }^{299}$, la ley 12, 1, 2 de Recaredo, el documento De fisco Barcinonensi y algunos fragmentos de las crónicas de Isidoro y de Juan de Bíclaro, la autora obtiene ciertas conclusiones. En primer lugar, afirma que la atribución de los reyes de imponer impuestos sobre el territorio y sobre las personas se sustentaba ideológicamente en el principio de conquista, principio que otorgaba a los jefes máximos del reino la plena autoridad sobre el territorio gobernado. En segundo lugar, asegura que la ideología visigoda asimilaba las concepciones imperiales sobre el cobro de los tributos e impuestos, haciendo del rey el máximo responsable del sistema fiscal; como tal obligaba a los funcionarios a: cumplir con la recepción del tributo, evitar los abusos de los recaudadores - y castigarlos si hubiesen cometido algún delito-, conceder exenciones fiscales y gravar con nuevos impuestos a la población. Por último, Valverde Castro sostiene que el rey fue el mayor beneficiario del sistema impositivo; los ingresos tributarios constituían los recursos que utilizaba para financiar el aparato estatal, asegurando el buen funcionamiento del reino y el beneplácito de sus súbditos.

Ahora bien, como anunciamos al principio, las conclusiones de Valverde Castro se basaron en principios ideológicos, y tal vez sólo sean válidas en el plano de lo

\footnotetext{
${ }^{298}$ VALVERDE CASTRO, Ma.R: "Monarquía y tributación en la Hispania visigoda: el marco teórico" Hispania Antiqva, 31, 2007.

${ }^{299}$ Los cánones analizados por esta autora son: Concilio de Toledo III, año 589, c. 21 y 18; Concilio de Toledo IV, año 633, c.3, c. 47 y c. 32 ; Concilio de Toledo XIII, año 683, tomo regio y c. 3 y Concilio de Toledo XVI, año 693 , c. 8.
} 
teórico/discursivo. La misma autora se pregunta si la monarquía visigoda realmente ejecutó “(...) en la práctica, la capacidad de poder casi ilimitado que la teoría política le concedía." ${ }^{300}$; no brinda una respuesta a este interrogante que deja abierto a futuras investigaciones. Sin embargo, lo interesante que demuestra este estudio consiste en que por lo menos en el plano de la teoría política fue el rey el encargado máximo de organizar, recaudar y utilizar (como lo creía más conveniente) los ingresos fiscales.

Otros autores intentan develar el sistema fiscal en funcionamiento. Uno de los principales documentos utilizados para esgrimir argumentos sobre el sistema fiscal ha sido el De fisco Barcinonensi ${ }^{301}$. A través de esta carta los obispos de la ciudad de Barcelona hacia el año 592 (Artemio, Sofronio, Galano y Juan) confirmaron en sus puestos a los numerarios nombrados por Escipión, conde del patrimonio de Recaredo. También estipularon el monto a pagar por los contribuyentes: por cada modio, nueve silicuas y una más por la tarea realizada, a lo cual se adicionaron cuatro silicuas por los cambios en los precios de los productos en que se pagaba el impuesto, incluyendo en ello la cebada. Finalizaron la carta exhortando a los agentes fiscales a que no exigiesen más de lo establecido.

Algunos autores analizando el documento visto ${ }^{302} \mathrm{y}$ otras referencias legislativas, consideran que el siglo VI los impuestos directos principales fueron el territorial (capitatio

\footnotetext{
${ }^{300}$ VALVERde CASTRO, Ma.R.: "Monarquía y tributación en la Hispania visigoda: el marco teórico". p. 250.

${ }^{301}$ De fisco Barcinonensi..., Concilios, p. 54. Este documento es tradicionalmente datado en el año 540; sin embargo, trabajos recientes defienden al año 592 como la fecha correcta. SOUVIRON BONO, S.: "Fiscalidad y control eclesiástico en la Hispania visigoda: supervisión de almas e impuestos", Baetica. Estudios de Arte, Geografia e Historia, vol. 31, Málaga, 2009. pp. 275-289.

${ }^{302} \mathrm{El}$ análisis de este documento también permite discutir sobre el papel de los obispos en la fiscalidad. A partir de esta carta y de la conversión de Recaredo al catolicismo en el año 589 García Moreno defendió que los obispos ocuparon puestos destacados en la maquinaria fiscal GARCíA MoReno, L.A.: Historia de la España visigoda... p. 281. Souviron Bono, luego de examinar exhaustivamente documentación disponible, concluyó que los obispos en Hispania no tuvieron el deber de cobrar directamente los impuestos sino sólo supervisar el proceso, controlar a los numerarios y a sus agentes, presentar los descontentos de la población en relación con los tributos y fijar - junto a los jueces del distrito y encargados del patrimonio fiscal- el gravamen de los impuestos en las reuniones conciliares de cada noviembre. SOUVIRON BONO, S.: "Fiscalidad y control eclesiástico en la Hispania visigoda: supervisión de almas e impuestos” ..., p. 289. De la misma opinión: Fuentes HinOJO, P., "Patrocinio eclesiástico, rituales de poder e historia urbana en la Hispania tardoantigua (siglos IV al VI)", Studia Historica, Historia antigua, vol. 26, 2008, p. 323. FERNÁNDEZ, D.: "What is the Fisco Barcinonensi about?", Antiquité Tardive, 14, 2006, pp. 217-224.
} 
terrena) y el personal (capitatio humana) $)^{303}$, otros creen que estos dos impuestos se fusionaron $^{304}$. También afirman que el collatio lustralis o solutio auraria (tributo pagado por los comerciantes), los derechos aduaneros y la annona seguían vigentes ${ }^{305}$. El importe de dichos impuestos era fijado en especie y seguía practicándose la adaeratio $^{306}$. Según reconstruyen Díaz Martínez y C. Martin, el carácter provincial de la estructura administrativa continuó en el reino ${ }^{307}$, conservando al rector provinciae y en un segundo escalafón al comes civitatis, quien debía controlar todo el territorio circundante de su ciudad. Examinando las menciones documentales (la mayoría de origen legislativa) Díaz Martínez deduce que el comes civitatis tuvo responsabilidades fiscales y anonarias. Para esta tarea fue ayudado por el numerarius y el thiufadus, quienes también actuarían como jueces ${ }^{308}$.

Sin embargo, como varios autores advierten ${ }^{309}$, la naturaleza de las fuentes hace muy difícil (sino imposible) conocer el funcionamiento de la red fiscal, y tal vez solo conozcamos el plan de recaudación, pero no su efectividad. A pesar de estas dificultades, la historiografía especializada avanza sobre su estudio.

Aquellos autores que se enmarcan en la tesis de Barbero y Vigil postulan, casi al unísono, que el gobierno central se vio privado de la entrada del metálico proveniente de las grandes fincas. Valverde Castro afirma que el fuerte proceso de feudalización que habría sufrido el reino godo permitió que el conjunto aristocrático obtuviese un mayor poder y una

\footnotetext{
${ }^{303}$ Sostienen esta afirmación: TORRES LOPEZ, M.: "El Derecho y el Estado", en TORRES LOPEZ, M. et al.: Historia ele España. España visigoda (414-711 de J. C.), Madrid, 1980, p. 244; GARCIA GALLO, A.: Curso de Historia del Derecho español., Madrid, 1956, p. 104.

${ }^{304}$ De forma reciente: WiCKHAM, C.: Una historia nueva de la Alta Edad Media ... pp. 96-97; DíAz MARTíNEZ, P.C.: "El reino visigodo en vísperas del 711: sistema político y administración". p. 35.

${ }^{305}$ García Moreno, L.A.: Historia de España Visigoda ..., p. 328; SALRACH, J. M.: "Del estado romano a los reinos germánicos: en torno a las bases materiales del poder del estado en la antigüedad tardía y la Alta Edad Media”. p. 122, DíAz MARTíneZ, P.C.: Hispania tardoantigua y visigoda ..., p. 455. Para el estudio de los distintos tipos de tasa, además de los textos citados, véase: THOMPSON, E.A.: The goths in Spain ... pp. 128 y ss; TORRES LOPEZ, M.: "El Derecho y el Estado". pp. 128 y ss; KING, P.D.: Derecho y sociedad en el reino visigodo..., p. 90-91; GARcía Moreno, L.A., "Algunos aspectos fiscales de la Península Ibérica durante el siglo VI", Hispania Antiqua, 1, 1971, pp.235-243. VALVERde CASTRO, Mª. R.: Ideología, simbolismo y ejercicio del poder real en la monarquía visigoda ..., p. 238.

${ }^{306}$ Sustitución del pago en especie por efectivo de valor equivalente.

${ }^{307}$ DÍAZ MARTíNEZ, P.C.: "El reino visigodo en vísperas del 711: sistema político y administración”. p. 36; MARTIN, C.: Lagéographie du pouvoir dans l'Espagne visigothique... pp. 165-175.

${ }^{308}$ DíAZ MARTíNEZ, P.C.: "El reino visigodo en vísperas del 711: sistema político y administración”. p. 38.

309 VALVERDE CASTRO, Ma.R: "Monarquía y tributación en la Hispania visigoda: el marco teórico". DíAZ MARTíNEZ, P.C.: “El reino visigodo en vísperas del 711: sistema político y administración”. p. 38.
} 
independencia respecto al centro, lo que significó que estuvo exento del pago al fisco ${ }^{310}$. Por su parte, Díaz Martínez sostiene que la causa de dicho fenómeno se debió a que los grandes propietarios, por encargo del estado central, fueron responsables de las tareas defensivas por lo cual

“el gasto militar que había sido el principal dispendio del reino se redujo drásticamente. Este proceso de feudalización, que al menos en la esfera militar parece indudable, desvirtuó de manera clara la justificación de la fiscalidad"311.

Wickham propone que el sistema tributario en el reino godo había caído en desuso al convertirse la entrega de tierras en el medio por el cual los reyes retribuían los servicios de los soldados ${ }^{312}$.

Desde otra perspectiva se plantea la existencia para el regnum visigodo de una red fiscal sujeta a la voluntad de las aristocracias locales antes que al centro.

Castellanos advierte que para comprender la implicancia social y política del régimen tributario se debe entender "the bipolar nature of taxation" 313 , esto es distinguir entre el fisco y los impuestos. El primero de estos dos elementos estaría constituido por todo el patrimonio regio, es decir las tierras y siervos fiscales (que no necesariamente eran sujetos no libres, sino individuos subordinados al fisco que contarían incluso con sus propios esclavos y tierras), bajo la supervisión del comes patrimonii. El fisco era administrado por el rey de acuerdo con las necesidades políticas del momento. Parte de los bienes fiscales fueron entregados en forma de regalos para construir alianzas y honrar la fidelidad prometida por los miembros de la aristocracia; también el fisco fue una herramienta de castigo, pues a través del medio legal de la incautación absorbía los bienes de aquellos que había cometido actos de traición o habían presentado algún signo de oposición; la capacidad de utilizar los atributos del patrimonio regio de una u otra forma dependía de la fortaleza de cada rey. El impuesto, el segundo elemento, recayó sobre los privati y estuvo controlado por las hegemónicas

\footnotetext{
${ }^{310}$ VALVERDE CASTRO, M${ }^{\mathrm{a}}$. R.: Ideología, simbolismo y ejercicio del poder real en la monarquía visigoda ..., $\mathrm{p}$. 241.

${ }^{311}$ DÍAZ MARTÍNEZ, P.C.: Hispania tardoantigua y visigoda ..., p. 458.

312 WiCKHAM, C.: Una historia nueva de la Alta Edad Media ..., p.170 y ss.

${ }^{313}$ CAStellanos, S.: "The political nature of taxation in Visigothic Spain", Early Medieval Europe, vol. 12, 2003, pp. 201-228. p. 216.
} 
aristocracias locales, lo cual les habría permitido mantener su independencia con respecto al centro. El autor remarca que la explotación del fisco ha sido una vía de comunicación entre el poder central y la periferia, un medio para construir alianzas políticas que permitió la pervivencia del reino por dos siglos.

Martín Viso considera que el sistema tributario no fue un sistema homogéneo porque estaba sujeto a la voluntad de las aristocracias locales ${ }^{314}$, cuya relación con el centro se encontraba continuamente bajo negociación; los aristócratas participaban del circuito fiscal utilizándolo como un "resorte para su estatus" a nivel local ${ }^{315}$, además del beneficio económico que pudieron obtener por la práctica de la adaeratio. La evidencia de la relación entre el centro y los potentes serían los depósitos de tremises de oro descubiertos en ciudades, sitios de altura e iglesias. El autor vincula estos hallazgos con un control fiscal a nivel comarcal, principalmente por medio de peajes, por parte de los potentes en su posición de "dominadores de las comunidades y, a la postre, legítimos representantes del poder"316. Martín Viso defiende que el elemento primario del dominio aristocrático fue el control de la tributación, restándole importancia a la explotación de las grandes propiedades en forma de fundi.

También Martín Viso junto a Díaz Martínez realizan un estudio semántico y filológico sobre un conjunto de pizarras numerales y con textos halladas en la provincia de Salamanca $^{317}$. Deducen que esas piezas - como otras análogas encontradas en toda la Península - constituyen la evidencia de una contabilidad destinada a registrar las entradas de un sistema de gestión de tipo fiscal. Los historiadores atribuyen al sitio de Salvatierra, y a otros castra, el carácter de centros de recaudación de los tributos a nivel local; y por el contexto arqueológico, la cerámica de calidad encontrada, algunos aspectos escultóricos y la invisibilidad del estado, presumen que fue el lugar físico de poder de la elite encargada del cobro de los impuestos a favor, en teoría, del estado. Asimismo, consideran que la

\footnotetext{
${ }^{314}$ MARTín VISO, I.: "<Tremisses y Potentes> en el nordeste de Lusitania (Siglos VI-VII)", Melanges de la Casa de Velázquez, 38, 1, 2008 (Ejemplar dedicado a: Actores de la Guerra de la Independencia), pp. 175-200. Mantiene su opinión en MARTín VISO, I.: "Huellas del poder: pizarras y poblados campesinos en el centro de la península Ibérica (siglos V-VII)".

${ }^{315}$ MARTín Viso, I.: "<Tremisses y Potentes> en el nordeste de Lusitania (Siglos VI-VII)". p. 3.

${ }^{316}$ Ibidem, p. 16.

${ }^{317}$ DíAZ MARTíNEZ, P. C \& I. MARTín VISO, I.: “Una contabilidad esquiva: las pizarras numerales visigodas y el caso de El cortinal de San Juan (Salvatierra de Tormes, España)".
} 
fiscalización de los tributos sería utilizada por la aristocracia como un medio para obtener beneficios económicos y un mayor estatus social, mientras que el centro aceptaba esas condiciones a cambio de "percibir un tributo quizás más simbólico que real, dentro de una relación indirecta con sus teóricos súbditos" 318 . Cerraron sus argumentos proponiendo que las pizarras de Salvatierra "se encontrarían en el quicio del paso entre el impuesto a la renta" ${ }^{319}$. Vemos en esta realidad descripta a una sociedad de carácter transicional.

El estudio de la acuñación monetaria también es importante para conocer el posible alcance de la monetarización de la sociedad y la pervivencia de la red fiscal. Pliego Vázquez, basada en una evidencia sólida que conjuga cálculos y estudios sobre las cecas godas, sugiere que los tremises de oro acuñados tuvieron como objetivo la construcción de relaciones de fidelidad. Las monedas recorrían trayectos entre el rey y la aristocracia creando relaciones políticas basadas en el regalo; esto explicaría para la autora el generalizado atesoramiento del numerario y su limitada circulación ${ }^{320}$.

Sánchez Pardo, partiendo de la importancia fundamental del estudio de la actividad minera en la región de Gallaecia, concluye que la moneda ha sido un instrumento de vinculación político-fiscal. El establecimiento de cecas próximas a las minas indicaría una articulación entre el poder central y las aristocracias locales, que se concretaba en la delegación de la explotación de los metales a través de pactos fiscales ${ }^{321}$. Este autor estima que el funcionamiento de las cecas (y la consiguiente explotación de los minerales) se debió al cobro de los impuestos. También la vitalidad de estas no puede ser explicada solo por la existencia de la actividad minera, las razones políticas y económicas pesaron tanto o más.

Parte de la historiografía atribuye una cierta vitalidad al sistema fiscal visigodo, mientras que otra observa un deterioro o un colapso total del mismo. Ahora bien, no existen — por lo menos en el estado actual del conocimiento, tal vez un análisis más profundo de las pizarras o el descubrimiento de nuevas piezas releve a este panorama - suficientes pruebas documentales que permitan que estas afirmaciones superen el plano de lo hipotético. ¿Por

\footnotetext{
318 Ibidem, p. 242.

${ }^{319}$ Idem.

${ }^{320}$ Pliego VÁzQuez, R.: "La Acuñación Monetaria en el Reino Visigodo de Toledo: el Funcionamiento de las Cecas”, Els Tallers Monetaris: Organització I Producció, Museu Nacional D'art de Catalunya. 2008, pp. 117141.

${ }^{321}$ SÁNCHEZ PARDO, J. C.: "Sobre las bases económicas de las aristocracias en la Gallaecia suevo-visigoda (ca. 530-650 d.C). Comercio, minería y articulación fiscal".
} 
qué existen lecturas tan disonantes sobre el mismo fenómeno? La respuesta la hallamos en el abordaje desde un marco analítico específico (por ejemplo, el feudalismo visigodo) y la naturaleza dispar de los testimonios. Alguno de estos - como la carta De fisco Barcinonensi, las leyes o las pizarras - dan cuenta de la continuidad del cobro del tributo y otros describen los obstáculos para la recepción de estos (principalmente los edictos reales de condonaciones impositivas $^{322}$ ).

La única aseveración posible de realizar a la luz de la documentación en uso es que la aristocracia (incluyendo en esta a los reyes) tuvo la intención de mantener con vida al sistema fiscal, tal como lo demostró Astarita ${ }^{323}$. La plasmación real de dicho deseo es incierta, aunque una mirada al contexto social nos puede ayudar a formular algunas afirmaciones.

Como hemos visto, en el reino visigodo no hubo una explotación uniforme del campesinado: el grado de dominación sobre las comunidades varió enormemente, la indocilidad de la mano de obra fue un fenómeno general y la incompleta cohesión territorial del reino constituyó además un factor que obstaculizaba la extracción del excedente. Debemos agregar que la alta aristocracia no pudo consolidar relaciones verticales con sus homónimas regionales y con las elites locales, sino que establecieron relaciones de carácter laxo, flexibles, más horizontales que verticales y organizadas desde una lógica reciprocitaria, como comprobaremos en los capítulos siguientes. Las aristocracias se relacionaban con el centro en busca de beneficios económicos, prestigio social y legitimación política, pero sus acciones no quedaban supeditadas a los deberes exigidos por Toledo; al contrario, tuvieron una autonomía más que importante. Las elites locales también mantendrían una distancia e independencia semejante con respecto a la alta aristocracia regional; una muestra de ello podría ser las vinculaciones precarias y difícilmente estructuradas de tipo militar (ver el capítulo seis).

Por consiguiente, los reyes ambicionaron financiarse con los recursos provenientes del cobro de los impuestos, mas por la crisis de dominación y la ausencia de una cristalización de jerarquías hegemónicas les fue imposible ejecutar de manera sostenida dichos cobros, lo que no quita que hayan tenido algunos éxitos esporádicos. De hecho, su voluntad de recaudar

\footnotetext{
322 Concilios, Toledo XIII, año 681, c. III, p. 419. IsID. Hist. Goth., p. 267. LV, 12, 1, 2, p. 407. Concilios, Zaragoza, c.5, p. 480.

${ }^{323}$ ASTARITA, C.: “Construcción histórica y construcción historiográfica de la temprana Edad Media”. p. 254.
} 
la podemos encontrar en pasajes documentales, aunque en los mismos también se evidencia la condición de autonomía de las aristocracias regionales que los reyes no pudieron contrarrestar.

En el año 683 Ervigio perdonó los tributos adeudados desde el 680 aduciendo que exigirlos significaría derrumbar la estabilidad del reino ${ }^{324}$. Por supuesto que los reyes que condonaron tributos lo hicieron para legitimarse en el poder y hacer uso de sus prerrogativas regias y así afianzar su autoridad ${ }^{325}$, pero aquí lo más interesante del Edicto ervigiano no es tanto su fin propagandístico sino lo que revela. El canon que estableció la condonación proclamó

"ut omne tributum praeteritorum annorum usque in anno primo regni sui, quod in privatis sive in fiscalibus populis reiacet, absolutionis perpetuae debeat sanctione laxari, et tantum de ipsis tributis praecipiens thesauris publicis exhiberi, quae exacta et non inlata fuisse constiterint ${ }^{, 326}$

Por este pasaje sabemos que ciertos miembros de la aristocracia tuvieron la facultad de captar tributos, pero no los hicieron llegar al arca regia. La clave propuesta por Martín Viso para leer las pizarras permite también entender este documento de una forma más clara.

En cuanto a las tierras de los reyes, las posesiones fiscales y privadas, son muy pocas las fuentes disponibles y su estudio sistemático es harto difícil. Sabemos que Leovigildo le donó a Nancto una tierra junto a sus habitantes y que ciertos cargos palatinos tuvieron la función de administrar el patrimonio fiscal ${ }^{327}$; también conocemos el nombre de una posesión de Recesvinto en territorio salamantino ${ }^{328}$. Otras menciones documentales hacen referencia a las posesiones fiscales y privadas de los reyes ${ }^{329}$; estos últimos datos salen a la luz cuando los palatinos y prelados reunidos en asamblea conciliar intentaron evitar la

\footnotetext{
324 Concilios, Toledo XIII, año 681, p. 413.

${ }^{325}$ VALVERDE CASTRO, Ma. R.: Ideología, simbolismo y ejercicio del poder real en la monarquía visigoda ..., $\mathrm{p}$. 239. GARCÍA LÓPEZ, Y.: Estudios críticos y literarios de la "Lex Wisigothorum"..., pp. 212 y 213.

326 Concilios, Toledo XIII, año 681, c. III, p. 419.

327 VAlverde CAStro, Ma ${ }^{a}$.R.: "Monarquía y tributación en la Hispania visigoda: el marco teórico", p. 246; DÍAZ MARTíNEZ, P.C.: "El reino visigodo en vísperas del 711: sistema político y administración”, p. 34.

${ }^{328}$ IUL. TOL. $H W$, p. 219.

${ }^{329}$ Ver el desarrollo del problema de la patrimonialización en el capítulo 5.
} 
patrimonialización del fisco. Por estos datos conocemos que los reyes controlaban bienes fundiarios ya sean propios o provenientes del fisco. Igualmente existen documentos que acreditan el patrimonio de la aristocracia laica y eclesiástica, ejemplo de ellos son: el testamento de Vicente de Huesca ${ }^{330}$ y el de Ricimiro, las menciones en las hagiografías de Emiliano $^{331}$, Fructuoso $^{332}$ y en los textos autobiográficos de Valerio del Bierzo ${ }^{333}$. Según se desprende de la lectura de estas fuentes, las grandes propiedades tuvieron un carácter disperso y fueron trabajadas por dependientes, realidad que podría corresponder a la zona que se extiende entre los Pirineos y el Valle del Ebro. En el noroeste de la Península pudieron existir propiedades de carácter más localista, como lo señalarían las pizarras para la zona de la actual Ávila ${ }^{334}$. Según Martín Viso, la ausencia en las pizarras de términos que hagan referencia a los fundos estaría indicando la falta de grandes propiedades dedicadas a la agricultura y trabajadas por mano de obra esclava ${ }^{335}$. A pesar de estos indicios, no tenemos suficientes datos sobre la gestión ni extensión de las tierras pertenecientes a la aristocracia o a los reyes ni sobre las condiciones jurídicas de los habitantes de ellas; la laguna documental impide avanzar con el estudio, por lo menos desde los testimonios escritos. Tal vez lo que sepamos de aquí en más sobre las propiedades regias sea solo lo que deduzcamos por el contexto social o la organización del campesinado, puntos ya analizados en páginas más arriba. Asimismo, los avances que se produzcan en el campo de la arqueología con seguridad ayudarán a resolver este problema.

(II) Vías de enriquecimiento de los reyes godos: botín de guerra, penas judiciales patrimoniales e incautación de los bienes de los particulares

\footnotetext{
${ }^{330}$ DíAZ MARTíneZ, P.C: "El testamento de Vicente. Propietarios y dependientes en la Hispania del siglo VI". ${ }^{331}$ BRAU. VSE, p. 217.

${ }^{332}$ MARTín VISO, I.: "Hispania en el periodo postromano (siglos V-VIII)". p. 40.

${ }^{333}$ VAL. Ord., p. 255.

${ }^{334}$ MARTÍN VISO, I.: "Hispania en el periodo postromano (siglos V-VIII)". p. 40; MARTíN VISO, I.: "Tributación y escenarios locales en el centro de la península Ibérica. Algunas hipótesis a partir del análisis de las pizarras visigodas". p. 220.

${ }^{335}$ Ibidem, p. 40.
} 
El estudio del derecho visigodo ha experimentado un renovado impulso ${ }^{336} \mathrm{y}$ con él nuevas perspectivas de análisis. Planas Alvarado advierte que el conjunto de leyes visigodas es más una recopilación que un código, pues contiene normas que abiertamente se contradicen entre si $^{337}$. También subraya la continuidad de algunas prácticas del derecho consuetudinario germano revestido con terminología romana ${ }^{338}$. Estos aspectos destacados ayudan a comprender la coexistencia de tres formas de castigo patrimoniales distintas: la compensación, la pena pecuniaria a favor del fisco y la incautación de bienes.

Los delitos graves contra los particulares (homicidio, rapto, violación, adulterio, infidelidad, insolvencia, entre otros) estuvieron reguladas bajo la figura romana de la traditio in potestatem, es decir, el derecho reconocido, de origen germano, a los ofendidos a perseguir y castigar al culpable ${ }^{339}$. A veces el castigo era la muerte en manos de la familia afectada, y en otras la reducción a la servidumbre o la compensación en bienes ${ }^{340}$. Para los delitos menores (como los daños producidos por los animales en tierras ajenas) se estipulaba una compensación monetaria para el damnificado que podía conseguir su equivalente en bienes $^{341}$. Por otro lado, los delitos cometidos por los hombres libres, sobre todo la alta aristocracia, contra los reyes o la patria eran castigados con el destierro, la excomunión y la incautación de bienes que pasaban bajo el control del rey. Este último mecanismo también constituyó un arma de acción política, por lo tanto, será analizado en el capítulo cinco. Otros

\footnotetext{
${ }^{336}$ Un dossier muy interesante: AA.VV.: "Le droit hispanique latin du VIe au XIIe siècle", Mélanges de la Casa de Velázquez, 41-2, 2011. También ver: AA.VV. : Symposium 1, 2016-2017: Law and Theology, Networkd and Neighnours, online: https://visigothicsymposia.org/symposia/. En especial: KELLY, M.: "Recceswinth's Liber Iudiciorum: History, Narrative and Meaning", pp. 110-130.

${ }^{337}$ Alvarado Planas, J.: "A modo de conclusiones: el Liber Iudiciorum y la aplicación del Derecho en los siglos VI a XI", Mélanges de la Casa de Velázquez, 41-2, 2011.

${ }^{338}$ Alvarado Planas, J.: "A modo de conclusiones: el Liber Iudiciorum y la aplicación del Derecho en los siglos VI a XI". Existe un viejo debate sobre la supervivencia de costumbres germanas en el derecho visigodo. También: Alvarado Planas, J.: El problema del germanismo en el Derecho español. Siglos V-XI, Madrid: Marcial Pons, 1997. Petit ha defendido la tesis contraria a Alvarado Planas. PEtIT, C.: "Consuetudo y mos en la Lex Visigotorum", Recueils de la Société Jean Bodin, 52, 1990, pp. 89-120. Ver también: VeLÁzQUEZ SORIANO, I.: "Jurial relations as an indicator of syncretism: from de law of inheritance to the dum inclicita of Chindaswinth", en Heather, P. (ed.): The Visigoths from the Migration Period to the Seventh Century. An Ethnographic Perspective, Woodbridge: The Boydell Press, 1999, pp. 225-259. Para más detalles sobre este debate ver el estado de la cuestión en: Miceli, P.: Derecho consuetudinario y memoria. Práctica jurídica y costumbre en Castilla y León (siglos XI-XIV), Madrid: Universidad Carlos III de Madrid, 2012.

${ }^{339}$ Alvarado Planas, J.: El problema del germanismo en el Derecho español..., pp. 240 y 241.

${ }^{340}$ Ibidem para ver los distintos delitos graves y sus correspondientes castigos.

${ }^{341}$ Ver: KING, P.D.: Derecho y sociedad en el reino visigodo..., p. 245 y ss.
} 
delitos considerados ofensas contra la comunidad eran castigados con penas pecuniarias o castigos físicos si se trataban de no ingenuos o insolventes. En muchas ocasiones la legislación señaló que el pago por el delito era a favor del fisco en su totalidad o de forma parcial (el particular afectado también recibía una parte). Basten algunos ejemplos para ilustrar lo dicho.

El Concilio de Toledo III del año 589 ordenó que si algún laico de elevada posición no obedeciese lo allí establecido perdería la mitad de sus bienes a favor del fisco, mientras que a un libre de baja posición social se le embargaría la totalidad y sería enviado al exilio ${ }^{342}$. Las leyes que organizaron el ejército estipularon las multas que eran percibidas por el conde de la ciudad ante su incumplimiento ${ }^{343}$.

La extensión y aplicación del derecho visigodo es un tema que se sigue debatiendo. Algunos autores consideran que la existencia de las Fórmulas visigodas y algunos textos jurídicos en pizarra serían pruebas de su extendido uso, mientras que otros defienden que sus disímiles revisiones y promulgaciones fueron meros actos de legitimación política de los reyes (imitando a los emperadores romanos), ya que gran parte de su contenido lo consideran impracticable. En el mismo sentido, también se ha señalado que el romanizado código legal no fue aceptado ni utilizado por ciertos sectores de la población de origen goda ${ }^{344}$.

Como hemos reseñado brevemente, existen vertientes historiográficas que mantienen opiniones contrarias sobre el sistema judicial visigodo. Más difícil es afirmar si funcionaba regular y sostenidamente. Supongamos que así lo fuese, ¿las multas apoquinadas por los castigados a favor del fisco llenaban las arcas regias o, como en el caso de los tributos, fueron captadas por los intermediarios? La dinámica social lleva a pensar que si los tribunales aplicaban las penas pecuniarias gran parte de ellas quedarían en manos privadas de los jueces o los condes, y su llegada al arca regia debió ser muy limitada. Los sobornos o las multas que recibieran los condes de las ciudades visigodas pudieron constituir un ejemplo de lo dicho.

\footnotetext{
342 “(...) si vero laicus fuerit et honestioris loci perosnae est, medietatem facultatum suarum amittat fiet viribus profutura; si vero inferiores loci persona est, amissione rerum suarum multatus in exilio deputetur.". Concilios, Toledo III, año 589, c. XXIII, p. 135.

${ }^{343}$ Ver capítulo 6.

${ }^{344}$ Alvarado PlanAs, J.: “A modo de conclusiones: el Liber Iudiciorum y la aplicación del Derecho en los siglos VI a XI”, Mélanges de la Casa de Velázquez, 41-2, 2011. También una síntesis de este debate en: LORING, Ma. I., PÉREZ, S. Y FuENTES, P.: La Hispania tardorromana y visigoda. Siglos V-VIII..., p. 357-360.
} 
La importancia del botín de guerra y la economía de rapiña es resaltada con continuidad. Duby afirma que la economía de guerra, la búsqueda periódica de botín y de esclavos fue una característica de la economía altomedieval ${ }^{345}$. Sin embargo, señalamos que en los últimos años la guerra de rapiña y la búsqueda de botín en los reinos que suceden al Imperio Romano son comprendidas como subsidiarias de los análisis que se centran en la guerra como un fenómeno social ${ }^{346}$; el papel del botín de guerra como un motor de la economía no es puesto en relevancia y se lo estudia más como un aspecto constituyente de la dinámica de la guerra. Por ejemplo, Halsall, señala que la obtención de títulos, honor y regalos fue uno de los objetivos de las guerras, además del botín ${ }^{347}$.

Los especialistas de la región escandinava ponderan más el factor del pillaje. Lindkvist implementa los conceptos de external and internal exploitation. El primero de ellos hace referencia a la extracción de riquezas por fuera de la sociedad local: la captura del botín, el pillaje, el saqueo, impuestos sobre las actividades mercantiles de extranjeros y la imposición de tributos a los vecinos, serían algunas de sus formas. El cobro de impuestos y tributos a los sujetos locales se correspondería con la explotación interna ${ }^{348}$. A partir de estos conceptos, muchos especialistas los utilizan para explicar el pasaje de una sociedad que se reproducía a través de las distintas formas de explotación externa a formas de explotación interna $^{349}$. Consideramos que el aporte de Lindkvist es sumamente interesante y es factible de aplicar para las distintas regiones de Europa. Permite revaluar el lugar del botín de guerra en las sociedades altomedievales, sin desconocer las otras variables de la economía regia.

Entre los primeros godos que ingresaron en tierras bajo dominio romano fue común el pillaje y la captura de riquezas, siendo el saqueo de Roma del año 410 encabezado por Alarico el más famoso. En este episodio, secuestraron vestiduras lujosas, oro, plata, piedras

\footnotetext{
${ }^{345}$ DuBY, G.: Guerreros y campesinos..., p. 94. En su tesis sostuvo que la economía de guerra del periodo altomedieval fue reemplazada por una economía basada en la explotación de la tierra. Ver especialmente: Ibidem, p. 102 y ss.

${ }^{346}$ Por ejemplo: HALSALL, G.: Warfare and society in the Barbarian West, 450-900. Londres: Routledge, 2003. PETERSEN, L.: Siege warfare and military organization in the successor states (400-800). Byzantium, the West and Islam, (History of warfare; volume 91), Leiden-Boston: Brill, 2013

${ }^{347}$ HALSALL, G.: Warfare and society in the Barbarian West, 450-900, p. 37.

${ }^{348}$ LINDKVIST, T.: "Social and Political Power in Sweden, 1000-1300: predatory incursions, royal taxation and the formation of a feudal state", en SAMSON, R. (ed.), Social Approaches to Viking Studies, Glasgow: Cruithne, 1991, pp. 137-145.

${ }^{349}$ Varios autores en: LINE, P.: Kingship and State Formation in Sweden: 1130 - 1290, Leiden; Boston; Köln: Brill, 2007.
} 
y objetos preciosos que pasaron a engrosar el tesoro regio, base simbólica-material de los primeros reyes caudillos visigodos ${ }^{350}$. En las incursiones bélicas exitosas la toma del botín y los saqueos eran las prácticas comunes y esperables (veremos la importancia de esto en la construcción de las relaciones entre los guerreros y los jefes militares en el capítulo seis) y ampliamente atestiguadas en las fuentes. La Crónica Biclarense detalla no solo las batallas ganadas por Leovigildo, sino también describe cómo se apoderó de los bienes y tierras de aquellos a los que sometió; del mismo modo, recoge la noticia de la toma del tesoro de los suevos cuando hizo prisionero al rey suevo Andeca ${ }^{351}$. Isidoro tampoco deja de anotar las veces que los reyes de sus historias saquearon, tomaron botín y rehenes ${ }^{352}$. Una actividad tan naturalizada también ha sido atestiguada en el último tercio del siglo VII por Julián de Toledo en su relato sobre la rebelión que aplastó Wamba ${ }^{353}$. Metálico, caballos, joyas, armas, prisioneros de guerra, rehenes y todos los bienes muebles que podrían conseguir conformaban el botín de guerra. Además, las tierras apropiadas engrosaban el patrimonio fiscal o privado de los reyes y el de sus compañeros de armas.

Teudis envió a Teudisclo a enfrentar a las tropas francas asentadas en la provincia tarraconense; tras la victoria del general godo, los vencidos ofrecieron una gran cantidad de metálico para que se les permitiese escapar con vida ${ }^{354}$. Situación similar describió el obispo Julián en el asalto a los vascos por parte del rey Wamba en el año 673: ganada la batalla, algunos habitantes fueron tomados como rehenes y otros pagaron tributos para que se les concediese el derecho a vivir ${ }^{355}$. En algunas ocasiones se demandaba un rescate por los rehenes, como ya se ha visto en la Regula Comunis X y en el fragmento isidoriano sobre los cautivos liberados luego de un pago realizado por el rey Sisebuto. La captura de rehenes y su liberación tras un pago fue también una práctica extendida en otras regiones europeas ${ }^{356}$.

\footnotetext{
${ }^{350}$ El saqueo está atestiguado por Olimpodoro, Sozomeno y Zósimo. Ver: VALVERdE CASTRO, Ma. R.: Ideología, simbolismo y ejercicio del poder real en la monarquía visigoda: un proceso de cambio..., p. $35 \mathrm{y}$ JIMÉNES GARNICA, A. M.: Nuevas Gentes, Nuevo Imperio..., p. 53 y ss.

${ }^{351}$ IOHAN BICL. Chr., p. 75.

352 ISID. Hist. Goth., pp. 191, 197, 221, 223, 241, 277, 293, 297, 311, 313 у 315.

${ }^{353}$ IUL. TOL. $H W$, pp. 226, 227, 234, 242 y 243.

${ }^{354}$ ISID. Hist. Goth., p. 241.

${ }^{355}$ IUL. TOL. $H W$, p. 226.

${ }^{356}$ Ver a modo de ejemplo documentos y bibliografía sobre esta práctica en el mundo franco. SARACHU, P.: "Guerra, relaciones de producción y economía en la Galia meridional post-romana", Trabajos y comunicaciones, 38, 2012.
} 
Los ataques ofensivos contra los pueblos asentados en el interior de la Península no solo proporcionaban riquezas metálicas o bienes de consumo, sino también fuerza de trabajo: los prisioneros de guerra eran reducidos a la esclavitud, y los vencidos que quedaban libres se ofrecían para trabajos o prestaciones; así lo ilustra el suceso en que los vascos, luego de ser sometidos por las armas por Suintila, fueron obligados a construir la ciudad de Ologicus y prometer obediencia a la autoridad regia y a sus órdenes ${ }^{357}$. Podemos entender este último actuar de Suintila como el sometimiento de un pueblo extranjero a un tributo, práctica ya impuesta por Leovigildo a los suevos ${ }^{358}$; estas formas constituyeron un trasvase regular, como lo ha indicado Duby ${ }^{359}$. Asimismo, comprendemos que estos tributos irregulares fueron una forma de explotación externa en una fase transicional hacia una explotación fija. El rescate de rehenes también debe considerarse en este mismo sentido, así como la toma de prisioneros para convertirlos en esclavos. Primero Bonnassie ${ }^{360}$ y luego McCormick señalan la importancia de la guerra y el secuestro como dos formas de aumentar el número de esclavos $^{361}$.

La apropiación de los bienes a través de las formas externas de explotación significaba una transferencia inmediata de los excedentes de los productores directos explotados por una aristocracia vencida, pero también fue menos permanente, más inestable. La explotación externa adquirió una gran importancia en una formación social donde la explotación interna era débil o escasamente impuesta. En el reino visigodo la red de recaudación de tributos y la toma de rentas tuvo grandes dificultades, de ahí que la búsqueda del botín, la toma de rehenes y la captura de prisioneros de guerra y la imposición de tributos hayan sido incesantes, constituyéndose en motores de la economía regia. Por lo tanto, consideramos factible proponer que cada incursión comandada por los reyes godos ${ }^{362}$ tuvo como una de sus finalidades la transferencia de las riquezas y esto supuso una entrada de bienes para nada desdeñable. Isidoro consideró que Recaredo comandó sus hombres contra los bizantinos

\footnotetext{
${ }^{357}$ ISID. Hist. Goth., p. 246.

${ }^{358}$ Collins, R.: La España Visigoda 409-711 ..., p. 51.

${ }^{359}$ DUBY, G.: Guerreros y campesinos..., p. 65.

${ }^{360}$ BonNASSIE, P.: "Supervivencia y extinción del régimen esclavita en el occidente de la alta Edad Media (siglos IV-XI)", en BonNASsIE, P.: Del esclavismo al feudalismo en Europa occidental, Barcelona: Crítica, 1991, p. 47 y ss.

${ }^{361}$ MCCORMICK, M.: "Complexity, chronology and context in the early medieval economy", Early Medieval Europe, 12, 2003, p. 311.

${ }^{362}$ Ver en el primer apartado de este capítulo los detalles sobre las incursiones regias.
} 
asentados en la Península y los vascos "ubi non magis bella tractasse quam potius gentem quasi in palaestrae ludu pro usu utilitatis uidetur exercuisse" ${ }^{363}$. Entendemos que Recaredo en las incursiones realizadas, además de movilizar a los guerreros, "ejercitarlos" y mostrar su superioridad militar, buscó botín para engrosar sus arcas y repartir entre sus leales.

Los reyes aumentaban el tesoro regio con los bienes capturados ${ }^{364}$, los daban como recompensa para los guerreros y los ofrecían como regalos para cerrar alianzas políticas. Como bien apunta Moreland, los objetos pueden ser regalos o bienes de intercambio, según el sentido social y cultural que los sujetos le den ${ }^{365}$.

El tesoro regio constituyó, además de una base material sumamente importante, un símbolo del dominio regio. El poder simbólico del tesoro limitaba su potencial uso material. Las piezas que lo componían se atesoraban; eran de esos bienes que se debían guardar, no entregar, pues quien lo poseía ostentaba el rango de rey ${ }^{366}$. El famoso episodio del missurium del tesoro visigodo (originalmente entregado por Aecio al rey Turismundo) es un claro ejemplo de ello, pasemos a detallarlo. Sisenando, con la intención de derrocar a Suintila, le pidió ayuda militar al rey franco Dagoberto a cambio de una pieza muy valiosa, una bandeja de oro de 500 libras. Con el éxito conseguido, el franco envió a dos de sus hombres por la bandeja prometida, mas los godos por la fuerza no permitieron que sucediera y a cambio los francos recibieron doscientos mil sólidos, un valor estimativo de la codiciada pieza ${ }^{367}$.

\footnotetext{
363 ISID. Hist. Goth., p. 264.

364 Sobre la importancia de los tesoros ver: HARDT, M.: "Royal Treasures and Representation in the Early Middle Ages", en PoHL, W. Y ReIMITZ, H. (eds.): Strategies of Distinction. The Construction of Ethnic Communities, 300-800. Serie Transformation of the Roman World 2, Leiden: Brill, 1998. GELICHI, S. (ed.): Tesori: forme di accumulazione della ricchezza nell'alto Medioevo (secoli V-XI), Roma: Viella, 2004, en especial GASPARRI, S.: "Il tesoro del re". También: TYler, E.M.: Treasure in the Medieval West, York: York Medieval Press, 2000.

${ }^{365}$ Moreland, J.: "Concepts of the early medieval economy”, en HANSEN, I. L. Y WiCKHAM, C. (eds.): The long eighth century, Leiden: Brill, 2000, p. 32.

366 VAlverde CAStro, Ma .R: "Monarquía y tributación en la Hispania visigoda: el marco teórico". pp. 247249.

367 “Eo anno quod partebus Spaniae, vel eorum regibus contigerit, non pretermittam. Defuncto Sisebodo rige climentissemo, cui Sintela ante annum circiter successerat in regnum, cum essit Sintela nimium in suis inicus, et cum omnibus regni sui primatibus odium incurrerit, cum consilium cytiris Sisenandus quidam ex proceribus ad Dagobertum expetit, ut ei cum exercito auxiliaretur, qualiter Sintillianem degradaret ad regnum. Huius beneficiae repensionem missurium aureum nobelissemum ex tinsauris Gothorum, quem Tursemodus rex ab Agecio patricio acceperat, Dagobertum dare promisit, pensantem auri pondus quinnentus. Quo audito, Dagobertus, ut erat cupedus, exercitum in ausillium Sisenandi de totum regnum Burgundiae bannire precepit.
} 
Los reyes sistemáticamente se aprovecharon de las formas de explotación externa para acrecentar el patrimonio regio y de los privados; aunque por la naturaleza de estas y la simplificación de la economía, la llegada de los bienes tuvo un ritmo irregular haciendo que su flujo fuera inconstante e impredecible.

La práctica de la incautación y expropiación de bienes de los enemigos del rey constituyó una vía más de enriquecimiento. En el capítulo cinco haremos un detallado análisis sobre ella, aquí solo adelantaremos algunas cuestiones.

Las confiscaciones de los bienes a los enemigos regios tuvieron un doble propósito: por un lado, engrosaban de manera significativa las riquezas que el rey pasaba a controlar y, por otro, anulaba la posición social de la familia afectada, pues sus derechos sobre lo incautado desaparecían junto a su estatus. Este medio de enriquecimiento pudo haberse constituido como uno de los más importantes para los reyes, si la patrimonialización de los bienes incautados se hubiera cumplido. Mas esto no llegó a cristalizar.

En el VIII Concilio de Toledo se advirtió que los reyes no debieran confundir (ni fusionar) sus patrimonios privados con los patrimonios regios, dando cuenta del deseo de la aristocracia de mantener la independencia entre $\operatorname{ambos}^{368}$. El objetivo que tuvieron fue establecer que el patrimonio fiscal debía utilizarse para la gloria y el honor del reino, es decir, para cubrir las necesidades del fisco o ayudar a los palatinos ${ }^{369}$. Asimismo, en el discurso con tono incriminatorio reprocharon que los reyes se hubieran apropiado de los bienes que habían recibido por ejercer el cargo, pues se preguntaron:

\footnotetext{
Cumque in Espania devolgatum fuissit, exercitum Francorum in ausiliandu Sisenando adgredere, omnis Gotorum exercitus se dicioni Sisenando subegit. Abundancius et Venerandus cum exercito Tolosano tanto usque Cesaragustam civitatem cum Sisenando acesserunt, ibique omnes Gotti de regnum Spaniae Sisenandum sublimant in regnum. Abundancius et Venerandus cum exercitu Tolosano munerebus onorati revertunt ad propries sedes. Dagobertus legacionem ad Sisenando rigi, Amalgario duce et Venerando dirigit, ut missurium illum quem promiserat eidem dirigerit. Cumque a Sisenando regI missurius ille legatarius fuissit tradetus, a Gotis per vim tolletur, nec eum exinde excobere permiserunt. Postea, discurrentes legatus ducenta milia soledus missuriae huius praecium Dagobertus a Sisenandum accipiens, ipsumque pensavit", FREDEEG. Chron., pp. 157 y 158.

${ }^{368}$ Concilios, Toledo VIII, año 653, p. 295.

${ }^{369}$ Ibidem, Toledo VIII, año 653, p. 290 Y 291). “(...) illus gravius innectentes quod ea quae videntur adquirere non regni deputant honori vel gloriae (...)”; “(...)et nec fisci usibus commode nec palatinis officis repperiantur in remedium salutare conlata."
} 
"Nam numquid ad illos aut populorum adventus aut rerum poterat concurrere census, nisi extitissent gloriae sublimate culminibus? Aut ab aequalibus illi potuerunt rerum coacervatione ditari, nisi subiectis glorioso apice potuissent adtolli? ",370

Estas preguntas retóricas que se registraron en el acta conciliar son sumamente interesantes e indican algunos aspectos ya vistos que resaltaremos. En primer lugar, confirmamos las prerrogativas regias sobre el cobro de censos y la capacidad de obtener por donaciones o de forma forzosa distintos tipos de bienes que debían ingresar a las arcas regias. Tanto el cobro de los tributos como la anexión de bienes al patrimonio (como tierras, viñas, siervos $^{371}$ ) fueron derechos exclusivos de aquellos que disfrutaron del trono, como más adelante el rey proclamó en la misma reunión conciliar:

"Regem etenim iura faciunt, non persona, quia nec constat sui mediocritate subdi sublimitatis honore: quae ergo honori debent honori deserviant, et quae reges adcumulant regno relinquant, ut quia eos gloria regni decorat, ipsi quoque gloriam regni non extenuent sed exornent ${ }^{\text {"372 }}$

Según estas evidencias los grandes del reino consideraban que el rey debía gobernar en beneficio de todos (publica utilitate) y la apropiación de los bienes fue duramente cuestionada y obstaculizada por la aristocracia ${ }^{373}$.

Tal como en el caso de los bienes adquiridos a través de las otras vías de enriquecimiento, los bienes incautados se transformaban en recompensas entregadas como sellos de las alianzas políticas que cimentaban la autoridad regia y el estatus del rango de la aristocracia involucrada. Estas riquezas materiales al convertirse en beneficios solo estuvieron retenidas por las manos regias de forma temporal, de forma transicional.

La naturaleza y las características esporádicas de los canales de enriquecimiento de los reyes no siempre pudieron asegurar el flujo regular de los recursos, lo que dificultaba la entrega de dones y premios a sus aliados políticos. La redistribución de riquezas en tiempo

\footnotetext{
${ }^{370}$ Ibidem, Toledo VIII, año 653, p. 290.

${ }^{371}$ Ibidem, Toledo VIII, año 653, p. 295.

372 Ibidem, Toledo VIII, año 653, p. 291.

373 DÍAZ MARTíNEZ, P.C.: “El reino visigodo en vísperas del 711: sistema político y administración” ..., p. 34 y ss.
} 
de escasez económica fomentaba la competencia intra-aristocrática, la cual estimulaba los conflictos por el poder del reino. Este aspecto será retomado cuando reflexionemos sobre la construcción de las alianzas políticas.

\section{CAPÍTUlo 4}

\section{LA FRAGILIDAD POLÍTICA Y LA OSCILACIÓN DEL PODER REGIO}

En este capítulo sistematizaremos los datos provenientes de los documentos con el fin de demostrar que la fragilidad política fue un rasgo estructural de la realeza visigoda toledana. Asimismo, planteamos los problemas en torno a la oscilación del poder regio.

El desarrollo que sigue se relaciona con los aspectos económicos estudiados con anterioridad, y deriva a los relacionados con la dinámica regia, objeto del próximo capítulo.

\section{1}

La fragilidad del sistema político y la oscilación del poder regio en las fuentes y problemas encontrados

Primer acercamiento

Un indicio que estimula el análisis sobre la fragilidad del sistema político y de la oscilación del poder regio del reino visigodo lo constituyen las incesantes luchas entre los 
grupos aristocráticos por ocupar la máxima jefatura del reino. El carácter endémico de las pugnas por el trono no ha sido invisible para los contemporáneos ${ }^{374}$; la incertidumbre ante el desorden político quedó registrada. Gregorio de Tours indica que después de Amalarico, Teudis fue elegido rey. En el año 548 fue asesinado, y Teudisclo fue ascendido al trono. Un tiempo después, se encontraba en un festejo, desbordante de felicidad, con sus amigos $\left(\right.$ amicis $\left.^{375}\right)$, de pronto las velas se apagaron y fue traspasado por una espada enemiga; entonces, Agila se convirtió en rey. Es por estos sucesos que Gregorio sentencia que los godos adoptaron la detestable costumbre de asesinar con sus espadas al rey que les disgustaba y colocaban en su reemplazo a alguien de su preferencia ${ }^{376}$. Por su parte el autor del cronicón Pseudo Fredegario registra el destronamiento de Tulga por parte de una facción aristocrática encabezada por Chindasvinto. Cuando el autor describe los motivos por los cuales se sublevaba la aristocracia, cuenta que Tulga era muy joven y se había volcado a todo tipo de crímenes y vicios. Escribió una oración muy interesante: Gotorum gens impaciens est, quando super se forte iogum non habuerit ${ }^{377}$. Durante su reinado, Chindasvinto, conocedor del morbum Gotorum para asesinar o deponer por la fuerza a sus propios reyes, realizó una gran purga que afectó a un sector de los magnates: algunos fueron muertos y otros exiliados, y repartió a las esposas, las hijas y los bienes entre sus fieles. El autor comenta que doscientos de los grandes del reino y quinientos del estrato medio fueron asesinados ${ }^{378}$.

\footnotetext{
${ }^{374}$ Las fuentes no hispanas utilizadas para ilustrar la inestabilidad goda son destacadas por CASTELLANOS, S.: Los godos y la cruz: Recaredo y la unidad de Spania, Madrid: Alianza, 2007, p. 144.

${ }^{375}$ Según Althoff el término de amicitia incluía fidelidad y devoción. ALTHOFF, G.: "Las amicitiae [amistades] como relaciones entre estados y pueblos”, en LiTTLE, L. K y RosenwEIN, B.H. (ed.): La Edad Media a debate, Madrid: Akal, 2003, pp. 304-333.

${ }^{376}$ GReg. TUR. Hist. Franc., p. 126. "Post Amalaricum vero Theuda rex ordinatus est in Hispaniis. Quem interfectum, Theudegisilum levaverunt regem. His dum ad caenam cum amicis suis aepularet et esset valde laetus, caereis subito extinctis, in recubitu ab inimicis gladio percussus, interiit. Post quem Agila regnum accepit. Sumpserant enim Gothi hanc detestabilem consuetudinem, ut, si quis eis de regibus non placuisset, gladio eum adpeterent, et qui libuisset animo, hunc sibi statuerent regem.". El subrayado es nuestro.

377 “El pueblo godo se impacienta cuando no está bajo un yugo pesado". FREDEEG. Chron., pp. 162.

${ }^{378}$ Ibidem, pp. 162 y 163. "Eo anno Sintela rex Espaniae, qui Sisenando in regno successerat, defunctus est. Uius filius nomini Tulga sub tenera aetate Spanies peticionem patris sublimatur in regno. Gotorum gens inpaciens est, quando super se fortem iogum non habuerit. Uius Tulganes aduliscenciam omnes Spania more soleto viciatur, diversa committentes insolencia. Tandem unus ex primatis nomini Chyntasindus, collictis plurimis senatorebus Gotorum citerumque populum, regnum Spaniae sublimatur. Tulganem degradatum et ad onos clerecati tunsorare fecit. Cumque omne regnum Spaniae suae dicione firmassit, cognetus morbum Gotorum, quem de regebus degradandum habebant, unde sepius cum ipsis in consilio fuerat, quoscumque ex
} 
El mismo Chindasvinto encaró una reforma de las leyes visigodas, y en una de ellas la ley 2, 1, 8 que lleva como título - "De his, qui contra principem vel gentem aut patriam refugi sive insulentes existunt"- reconoció que el reino experimentó una violenta destrucción provocada más por el continuo orgullo de los desertores que por la acción de los enemigos extranjeros ${ }^{379}$.

Estos tres episodios, elegidos entre muchos otros que registran las fuentes sobre los violentos hechos ocurridos alrededor de los reyes, constituyen un disparador y nos acercan al problema de la inestabilidad política regia.

Los hechos de violencia dirigidos contra la figura regia constituyen una variable a reconsiderar, restándoles el carácter acontecimental que se les han otorgado. Es corriente observar que los mismos son frecuentemente subestimados, vistos solo como hitos de una historia episódica ${ }^{380}$ o directamente no se les atribuye importancia, al punto de desnaturalizar sus objetivos; escasos son los estudios que comprenden dicho fenómeno como algo estructural $^{381}$.

eis uius viciae prumtum contra regibus, qui a regno expulsi fuerant, cognoverat fuesse noxias, totus sigillatem iubit interfici, aliusque exilio condemnare, eorumque uxoris et filias suis fedelebus cum facultatebus tradit. Fertur, de primatis Gotorum hoc vicio repremendo ducentis fuisse interfectis; de mediogrebus quingentis interfecere iussit. Quoadusque hoc morbum Gotorum Chyntasindus cognovissit perdometum, non cessavit quos in suspicionem habebat gladio trucidare. Goti a vero Chyntasindo perdomiti, nihil adversus eodem ausi sunt, ut de regebus consuaeverant inire consilium. Chyntasindus cum esset plenus dierum, filium suum nomine Richysindum in omnem regno Spaniae regem stabilivit. Chyntasindus paenetentiam agens, aelymosinam multa de rebus propries faciens, plenus senectutae fertur nonagenarius moretur". El subrayado es nuestro. Sobre el término "senatorebus Gotorum" ver: SÁNCHEZ ALBORNOZ, C.: "El Aula Regia y las asambleas políticas de los godos". p. 19.

379 "Quantis actenus Gotorum patria concussa sit cladibus, quantisque ingiter quatiatur istimulis profugorum hae nefanda supervia deditorum, ex eo pene cunctis est cognitum quod patrie diminutionemagnoscunt, et hac hoccasione potius quam expugnandorum hostium externorum arma sumere sepe conpellimur." $L V, 2,1,8$. pp53 y 54 .

${ }^{380}$ COLlins, R. La España Visigoda 409-711 ...; GARCÍA MORENO, L. Historia de la España visigoda.; IsLA FREZ, A. "El officium palatinum visigodo. Entorno regio y poder aristocrático", Hispania: Revista española de historia, 2002, Vol. 62, 212, pp. 823-847. y "Conflictos internos y externos en el fin del reino visigodo". Hispania: Revista española de historia, 2002, Vol. 62, 211, pp. 619-635; SÁNCHEZ ALBORNOZ, C. "Donde y cuando murió Don Rodrigo, último rey de los godos", Cuadernos de Historia de España, Buenos Aires, 1945, 3, pp. 5-105.

${ }^{381}$ BARbero, A. \& Vigil, M: La formación del feudalismo en la Península Ibérica; DíAz MarTínez, P.C. y VALVERDE, M. R "The theoretical strength and practical weakness of the visigothic monarchy of Toledo". FRIGHETTO, R. "O problema da legitimidade e a limitaçao do poder región a Hispania visigoda: o reinado de Ervígio (608-687)”. LORING, Ma. I., PÉREZ, S. Y FUENTES, P.: La Hispania tardorromana y visigoda. Siglos VVIII. 
En esta sección introductoria del problema realizaremos un cuadro en el cual registramos los conflictos intra-aristocráticos desde mediados del siglo VI hasta el fin del reino como entidad política con un doble propósito: demostrar el carácter sistemático de los conflictos y comenzar a interpretar los motivos que empujaban a la aristocracia a sublevarse al poder regio. Para la realización de este cuadro utilizamos todas las fuentes sobre el reino visigodo disponibles.

Todos los desafíos abiertos o atentados encubiertos tuvieron el mismo objetivo por parte del líder que los organizó: deponer al rey, ocupar el trono y en pocas excepciones dividir el territorio ${ }^{382}$. Excluimos de la lista las contiendas en las cuales los oponentes fueron pueblos vecinos, ya sean provenientes de la Península Ibérica no sometidos a la tutela visigoda o extranjeros, pues consideramos que esos conflictos no siempre debilitaron al dominio del rey, ya que si eran exitosos conformaban una fuente importante de recursos y un elemento de legitimidad política. Aunque sí debemos advertir que si esas batallas eran perdidas el prestigio del rey podría verse seriamente socavado y su autoridad cuestionada. Entonces sí se convertirían en potenciales causas de levantamientos internos ${ }^{383}$.

\section{Cuadro 1}

\begin{tabular}{|c|c|c|}
\hline Reinado & Rey & Conflictos aristocráticos \\
\hline $526-531$ & Amalarico & Asesinado en Barcelona, se presupone por sus propios \\
& & \\
& & \\
& & \\
\hline $531-548$ & Teudis & Asesinado, posiblemente por instigación del grupo de \\
& & Amalarico. \\
\hline $548-549$ & Teudisclo & Asesinado en Sevilla. \\
\hline $567-572$ & Liuva I & Revueltas nobiliarias regionales no exitosas. \\
\hline
\end{tabular}

\footnotetext{
${ }^{382}$ Estos datos fueron tomados de MARTIN, C.: La géographie du pouvoir dans l'Espagne visigothique...

${ }^{383} \mathrm{El}$ desempeño en la guerra como factor constituyente de poder es tratado en el último capítulo.
} 


\begin{tabular}{|c|c|c|}
\hline $573-586$ & Leovigildo & $\begin{array}{l}\text { Levantamiento en el año } 579 \text { de su hijo Hermenegildo y un } \\
\text { grupo de nobles católicos por el control del reino. No exitoso. } \\
\text { Posibles intenciones de separación territorial. } \\
\text { En el año } 585 \text { Malaricus pretendió el restablecimiento del } \\
\text { reino suevo; claras intenciones separatistas. }\end{array}$ \\
\hline $586-601$ & Recaredo I & $\begin{array}{l}\text { Cuatro sublevaciones con participación de la aristocracia: } \\
\text {-en el año } 587 \text { en la provincia de Narbona } \\
\text { - en el año } 588 \text { en Mérida } \\
\text { - en el año } 589 \text { en Toledo } \\
\text { - en el año } 590 \text { en la Provincia Cartaginense } \\
\text { Ninguna fue exitosa. }\end{array}$ \\
\hline $601-603$ & Liuva II & En el verano del año 603 fue asesinado por Witerico. \\
\hline $603-610$ & Witerico & Asesinado por un miembro de su círculo íntimo. \\
\hline $610-612$ & Gundemaro & No se registran. \\
\hline $612-621$ & Sisebuto & Posible envenenamiento. \\
\hline 621 & Recaredo II & Levantamiento exitoso comandado por el duque Suintila. \\
\hline $621-631$ & Suintila & Revuelta de Geila. Levantamiento exitoso de Sisenando. \\
\hline $631-636$ & Sisenando & No se registran. \\
\hline $636-639$ & Chintila & $\begin{array}{l}\text { Sin datos concretos. No obstante, por la naturaleza de sus } \\
\text { medidas se presume una atmósfera amenazante para con su } \\
\text { reinado. }\end{array}$ \\
\hline $639-642$ & Tulga & $\begin{array}{l}\text { Hijo de Chintila asociado al trono por su padre. Depuesto por } \\
\text { una revuelta encabezada por Chindasvinto. }\end{array}$ \\
\hline $642-653$ & Chindasvinto & $\begin{array}{l}\text { Adoptó medidas represivas contra un número importante de } \\
\text { familias. No se registran sublevaciones. }\end{array}$ \\
\hline
\end{tabular}




\begin{tabular}{|c|c|c|}
\hline $649-672$ & Recesvinto & En el año 660, aplastó una revuelta encabezada por Froia. \\
\hline $672-680$ & Wamba & $\begin{array}{c}\text { En el } 673 \text { Salió exitoso de la sublevación organizada por } \\
\text { Ilderico y Paulo; de claras intenciones separatistas. Depuesto } \\
\text { por una maniobra de Ervigio en el año } 680 .\end{array}$ \\
\hline $680-687$ & Ervigio & $\begin{array}{l}\text { Se sabe que confiscó bienes de una parte de la aristocracia } \\
\text { laica. Sin más datos. }\end{array}$ \\
\hline $687-702$ & Égica & $\begin{array}{c}\text { En el año } 693 \text { hizo frente con éxito a una conjura planeada } \\
\text { por Sisiberto, obispo de Toledo. } \\
\text { Posible sedición de Sunifredo. }\end{array}$ \\
\hline $700-710$ & Witiza & Se enfrentó a Rodrigo. \\
\hline 710 & Agila II & Guerra contra Rodrigo. \\
\hline $710-711$ & Rodrigo & Enfrentado a la facción de Witiza. Derrotado por los árabes. \\
\hline
\end{tabular}

De la sistematización de la información inferimos que de veinticinco reyes de los cuales se tienen noticias concretas (se conocen sólo por testimonios numismáticos los nombres de Iudila c. ¿625-650? y Sunifredo c. ¿692-702? ${ }^{384}$ ), sólo cuatro tuvieron la gracia de no enfrentar algún tipo de conflicto, doce fueron depuestos y otros siete salieron airosos de las crisis (los últimos dos Ágila II y Rodrigo estaban en pleno enfrentamiento cuando entraron los musulmanes a la península). Los conflictos aristocráticos tenían diversas modalidades: a veces fueron revueltas abiertas que se extendían por varias regiones; tales son los casos de las sublevaciones dirigidas por Atanagildo, las perpetradas contra Liuva I, la encabezada por Hermenegildo, la originada en el año 587 en Narbona comandada por dos condes arrianos llamados Granista y Vildigerno junto al obispo Ataloco contra Recaredo, la ideada por Sisenando para deponer a Suintila, la dirigida por Froia contra Recesvinto y la organizada por Paulo; otros se materializaron en conspiraciones que tenían como fin asesinar al rey; tal fue el destino que sufrieron Liuva II, Witerico (posiblemente) Sisebuto, Tulga y Égica; o simplemente privarlo de la investidura, como en el caso de Wamba. De muchas otras no se poseen datos suficientes como para brindar mayores detalles, sólo podemos saber de

${ }^{384}$ Pliego VÁzQUeZ, R.: La moneda visigoda, pp. 177 y 178. 
su existencia por las denuncias de los reyes y de las medidas adoptadas en pos de condenar a los traidores. ¿Cómo podemos explicar esta debilidad estructural del sistema político y del poder de los reyes visigodos del reino de Toledo?

Algunos autores proponen que la fragilidad política institucional tuvo lugar en los gobiernos de los reyes de débiles personalidades. En nuestra opinión, esta hipótesis queda desacreditada al observar que los reyes considerados tradicionalmente como "fuertes", como Leovigildo, Recaredo, Chindasvinto y Recesvinto (quienes redactaron leyes que fueron incorporadas al Liber Iudiciorum, uno de los motivos principales por lo cual se les otorga este epíteto), hicieron frente a revueltas aristocráticas tanto como sus pares más "débiles". De igual modo, disentimos con las posturas historiográficas que sostienen que el conflicto entre la aristocracia y la realeza (entendidas como bandos totalmente discordantes y contradictorios) desataba las revueltas alrededor del centro, ya que no terminan de explicar los motivos subyacentes de las mismas, solo observan los síntomas del problema.

Tampoco encontramos la solución en los argumentos que reconocen los hechos de violencia contra los reyes como un rasgo esperable y natural, constitutivo y privativo solo de una etapa formativa del reino. Dicha etapa pertenece a un apartado de la división tripartita de la historia del reino que, con sutiles matices, la historiografía canonizó. Desarrollamos uno de estos esquemas como ejemplo.

Loring García, Dionisio Pérez y Fuentes consideran la formación del reino visigodo de Toledo como el primer momento del proceso, comprende: la instalación goda en Hispania, las rencillas políticas de mitad del siglo VI, la ampliación y control territorial por parte de Leovigildo y la conversión de Recaredo; también se incluye en este periodo el intervalo de tiempo que comenzó en el año 603 y finalizó en el 642, que tuvo como particular característica el despliegue de continuas turbulencias políticas, destacando solo los reinados de Sisenando y Chintila como gobiernos estables. En la segunda etapa se desarrolló el fortalecimiento institucional regio, la militarización del aparato administrativo y la participación de los obispos católicos en la construcción de la ideología regia. La última fase abarca lo que los autores identifican como el proceso de feudalización y el fin del reino ${ }^{385}$. Los hechos violentos ocurridos en la segunda etapa se minimizan, y los de la tercera son entendidos como parte de la dinámica feudal que tuvo lugar. Orlandis, García Moreno,

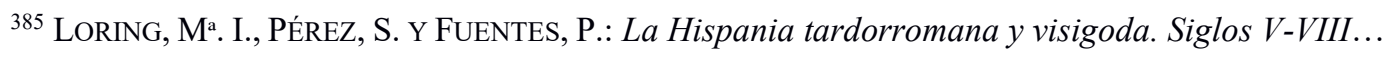


Thompson y King mantienen periodizaciones similares ${ }^{386}$. El excesivo énfasis que han puesto los autores a la hora de señalar las diferencias entre las etapas constitutivas del reino visigodo soslayó los rasgos que se conservan durante el largo siglo VII visigodo. Si bien es innegable que ciertos hitos políticos existen como mojones que señalan el comienzo y el fin de cada etapa o dan cuenta de evoluciones internas, ninguno de ellos supuso un cambio de estructuras sociales ni políticas. La división en etapas de la historia es un formato de manual, que responde a la necesidad de organización de los esquemas de redacción antes que a resolver problemas complejos.

Entonces, si subrayamos que cierto sector de la historiografía no considera que los reyes visigodos experimentaron una fuerte oscilación del poder político y que no sufrieron hechos de violencia interna, y otro sector no encuentra una respuesta satisfactoria que explique la esencia de la fragilidad política, estamos obligados a demostrar fácticamente la fragilidad política institucional y del dominio regio; y luego desarrollar nuestras líneas de investigación.

Los Concilios Eclesiásticos, las asambleas generales del reino visigodo: su valor documental para el estudio de los reyes y sistematización de los datos

Antes de analizar los datos concretos provenientes de los Concilios sobre la fragilidad institucional y la oscilación del poder regio, resulta elemental conocer la evolución y funcionamiento de estos cónclaves con el fin de ponderar sus indicios documentales.

Los archivos canónicos hispanos comenzaron a recopilarse por sus contemporáneos. La Capitula Martini realizada por Martín de Braga es la primera colección de la cual tenemos noticias. Del siglo VI o VII conocemos la Colección Novara y el Epitome Hispánico de finales del siglo VI ${ }^{387}$; la de mayor importancia es la Colección Canónica Hispana, que tuvo tres momentos de compilación: Isidoro de Sevilla en el año 634 inició la serie ${ }^{388}$, entre el 681 y el 683 Julián de Toledo hizo su aporte y la tercera se realizó a finales del siglo VII o comenzado el siglo VIII ${ }^{389}$. El cuerpo documental completo incluye treinta y siete concilios

\footnotetext{
${ }^{386}$ MARTIN VISO, I.: "Hispania en el periodo postromano (siglos V-VIII)”. pp. 37 y ss.

${ }^{387}$ CODOÑER, C. (coord.).: La Hispania visigótica y mozárabe: dos épocas en su literatura, p. 301.

${ }^{388}$ Colección Canónica Hispana, ed. MARTÍNEZ DÍEZ, G.: I vol., C. S. I. C., Instituto Enrique Flórez, MadridBarcelona, 1966, pp.306-309.

${ }^{389}$ CODOÑER, C. (coord.).: La Hispania visigótica y mozárabe: dos épocas en su literatura ..., p.302 y ss.
} 
celebrados entre los inicios del siglo IV hasta el año 694. Se conoce por un índice un concilio del año 702 cuyas actas se perdieron ${ }^{390}$. Un conjunto de manuscritos conservados contiene las colecciones y constituyen la base que utilizan los expertos para la edición crítica de estas fuentes $^{391}$.

Un aspecto por destacar es la evolución que los Concilios hispanos experimentaron como institución política. En su principio, no participaban los reyes o personalidades influyentes de la aristocracia laica, y los prelados reunidos resolvían cuestiones de materia eclesiástica (regulación de las prácticas litúrgicas, discusiones en torno al dogma y la doctrina) y derecho canónico (sanción sobre el comportamiento de los sacerdotes y catecúmenos, aplicación de castigos para quienes cultiven costumbres paganas). Las primeras intervenciones regias en territorio hispano registradas fueron la convocatoria del suevo Ariamiro para la celebración del Concilio de Braga del año $561^{392}$ y la de Mirón para el segundo Concilio de Braga del año 572 393 ; ninguno de estos dos presentó cuestiones por tratar ni firmó el cierre de las actas. En los escritos conciliares previos y posteriores no suevos, los obispos solo nombraron a los reyes en la datación de la reunión (tal vez sea como indicio de reconocimiento de la figura regia como proponemos en las páginas siguientes). Fue a partir del año 589, y con mayor fuerza en el año 633, cuando estos cónclaves (especialmente los celebrados en Toledo) comenzaron a funcionar como verdaderas asambleas generales del reino ${ }^{394}$ — donde participaban la alta clerecía, abades, presbíteros y diáconos, el rey, miembros de la aristocracia y ocasionalmente la comitiva personal del rey, los fideles regis ${ }^{395}$ — y se erigieron como instrumento de gobierno ${ }^{396}$.

\footnotetext{
${ }^{390}$ Ibidem, p. 298.La Crónica Mozárabe de 754 afirmó que Witiza convocó varios Concilios en la ciudad de Toledo durante su reinado, sin embargo, las actas de estos Concilios no se han conservado. Chronica muzarabica anni 754, p. 65.

${ }^{391}$ Concilios, pp .7 y ss. Colección Canónica Hispana, ed. MARTÍNEZ DÍEZ, G. primera parte.

${ }^{392}$ Concilios, Braga I, año 561, apertura, p. 65.

${ }^{393}$ Ibidem, Braga II, año 572, p. 78.

${ }^{394}$ DopsCH, A.: Fundamentos económicos y sociales de la cultura europea ..., p 250. DÍAZ MARTíNEZ, P.C los considera, a partir del año 633, instituciones políticas que tienen un carácter de "suprema asamblea legislativa, encargada de regular la marcha del Estado, a la vez que se convierte en el más alto tribunal del reino", en Hispania tardoantigua y visigoda..., p. 411.

${ }^{395}$ Concilios, Toledo V, año 636, p. 226.

${ }^{396}$ ARCE, J.: Esperando a los árabes... p. 238.
} 
La institución conciliar tuvo un carácter abierto, flexible y acomodaticio a los cambiantes tiempos políticos ${ }^{397}$, y a medida que se convertían en el espacio donde se desarrollaban las mayores discusiones políticas y en uno de los espacios de legitimación del poder político regio ${ }^{398}$ se elaboraba su protocolo de celebración.

En el Concilio de Toledo III del año 589, en su canon dieciocho, se dispuso a reunir una vez al año a los obispos en el lugar elegido por el metropolitano, quedando nula la prescripción de celebrar dos concilios al año por motivo de la lejanía y pobreza de las iglesias de Spaniae. Se obligó a los “... iudices vero locorum vel actores fiscalium patrimoniorum ... ${ }^{, 399}$ a acudir a las reuniones con el fin de dar cuenta de sus actuaciones en nombre del fisco. El cuarto Concilio de Toledo del año 633 confirmó la norma del tercer Concilio toledano y agregó la fórmula según la cual debía llevarse a cabo la reunión, la cual detallamos a continuación.

$\mathrm{Al}$ alba, se reunían los participantes en una basílica; en el recinto se hacían presentes los obispos ocupando los asientos de acuerdo con su antigüedad e importancia jerárquica, detrás de ellos los presbíteros y los diáconos de pie. Luego — si la convocatoria había sido por orden del rey - ingresaban los seglares y, por último, los notarios encargados de leer los pliegos por tratar y tomar nota. Una vez finalizado el acto de orar, el rey brindaba un discurso de exhortación para que los allí reunidos dispensasen sobre los preceptos escritos en el tomo regio. Se prohibía la salida de cualquier obispo antes de finalizada las deliberaciones, pues se sentenció que todo lo decidido de común acuerdo debería ser firmado por todos los miembros de la alta jerarquía eclesiástica ${ }^{400}$.

Las actas conciliares están constituidas sólo por las resoluciones adoptadas por la asamblea luego de lograr el apoyo unánime de los reunidos, pues los notarios transcribieron los dictámenes y decretos aprobados y no su desarrollo completo, el cual podía extenderse durante varios días. Sin embargo, en las actas hallamos ciertas expresiones que revelan que

397 ORLANDIS, J.: Historia de Los Concilios de la España Romana y Visigoda, Eunsa: Ediciones de la Universidad de Navarra, 1986, p. 168.

${ }^{398}$ Sánchez Albornoz propone la existencia de Asambleas políticas en el siglo VII distintas a los Concilios. SÁNCHEZ AlbornOZ, C.: "El Aula Regia y las asambleas políticas de los godos". pp. 99 y ss. Las alusiones en las fuentes sobre estas Asambleas son tan escasas que nos resulta imposible un estudio sistemático sobre ellas. Mismo problema en adherir o rechazar la propuesta de Sánchez Albornoz.

399 Concilios, Toledo III, año 589, c. XVIII, p. 131; Toledo IV, año 633, c. III, p. 188; Toledo XI, año 675, c. XV, p. 366; Toledo XII, año 681, c. XII, p. 400.

${ }^{400}$ Ibidem, Toledo IV, año 633, c. IV, p. 189-190. 
los cánones promulgados se sometieron a discusión y deliberación por todo el cuerpo conciliar $^{401}$ y que, si se trataban asuntos de capital importancia para el reino en general, hubo debates enzarzados: en el año 653, ante el requerimiento del rey Recesvinto sobre los expatriados y traidores de la época de Chinsdavinto ${ }^{402}$, los presentes

"Secundae disputationis occursu adfuit negotium tam difficile quam et grave, in quo de refugis atque perfidis disputatione conmota, utrum ne posset eorumdem temperari sententia damnatorum, magno satis conatu est exquisitum" $"$.

El ascenso al trono de Ervigio estuvo ceñido de intrigas, para disipar las mismas este rey se dirigió a la asamblea conciliar reunida en el año 681 diciendo:

“(...) ecce brevi complexa vel exarata devotionis meae negotia in huius tomi conplicatione agnoscenda perlegite, perlecta discutite, discussa elimatis ac decretis titulorum sententiis definite (...)" ${ }^{\prime 404}$.

Además, destacamos que los cánones conciliares fueron en su mayoría decisiones subscritas con base en hechos ocurridos, amenazas probables o situaciones de crisis que debían resolverse. Las imágenes que trasmiten las actas conciliares son tan vívidas, a pesar del filtro de los copistas, que pueden ser leídas como diarios de sesiones que reflejan el accidentado ritmo político del reino. Aquí radica su gran valor documental.

Observadas la evolución y el funcionamiento interno de los concilios, empezaremos el examen sobre los datos referentes a la fragilidad política y la oscilación del poder regio.

Un primer indicio sobre el problema planteado lo constituye la incapacidad de celebrar, con participación regia y anualmente, los Concilios tal y como lo disponía la norma. El cuadro debajo asienta los Concilios de los cuales se poseen datos desde la conversión de Recaredo al catolicismo hasta el año 694.

\section{Cuadro 2}

\footnotetext{
${ }^{401}$ Concilios, Sevilla II, año 619, c. IX, p. 169; Toledo IV, año 633, c. IV, p. 190; Toledo IV, año 633, c. LXXV, p. 217; Toledo VI, año 638, c. III, p. 236; Toledo VI, año 638, c. XIX, pp. 245-246; Toledo X, año 656, introducción, p. 308.

${ }^{402}$ Loring, Ma. I., PÉREZ, S. Y FuENTES, P.: La Hispania tardorromana y visigoda. Siglos V-VIII..., p 187.

${ }^{403}$ Concilios, Toledo VIII, año 653, c. II, p. 268.

${ }^{404}$ Ibidem, Toledo XIII, año 683, introducción, p 381.
} 


\begin{tabular}{|c|c|c|c|c|c|}
\hline $\mathbf{N}^{\mathbf{0}}$ & Año & Concilio & $\begin{array}{c}\text { Carácter } \\
\text { general }\end{array}$ & $\begin{array}{c}\text { Participación } \\
\text { regia }\end{array}$ & Rey convocante \\
\hline 1 & 589 & $\begin{array}{c}\text { Concilio de Toledo } \\
\text { III }\end{array}$ & Sí & Sí & Recaredo \\
\hline 2 & 589 & Concilio de Narbona & No & No & - \\
\hline 3 & 590 & Concilio de Sevilla & No & No & - \\
\hline 4 & 592 & Concilio de Zaragoza & No & No & - \\
\hline 5 & 597 & Concilio de Toledo & No & No & - \\
\hline 6 & 598 & Concilio de Huesca & No & No & - \\
\hline 7 & 599 & $\begin{array}{l}\text { Concilio de } \\
\text { Barcelona II }\end{array}$ & No & No & - \\
\hline 8 & 610 & $\begin{array}{l}\text { Decreto de } \\
\text { Gundemaro }\end{array}$ & No & Sí & Gundemaro \\
\hline 9 & 614 & Concilio de Egara & No & No & - \\
\hline 10 & 619 & Concilio de Sevilla II & No & No & - \\
\hline 11 & 633 & $\begin{array}{c}\text { Concilio de Toledo } \\
\text { IV }\end{array}$ & Sí & Sí & Sisenando \\
\hline 12 & 636 & $\begin{array}{c}\text { Concilio de Toledo } \\
\text { V }\end{array}$ & Sí & Sí & Chintila \\
\hline 13 & 638 & $\begin{array}{c}\text { Concilio de Toledo } \\
\text { VI }\end{array}$ & Sí & Sí & Chintila \\
\hline 14 & 646 & $\begin{array}{c}\text { Concilio de Toledo } \\
\text { VII }\end{array}$ & Sí & No & Chindasvinto \\
\hline 15 & 653 & $\begin{array}{c}\text { Concilio de Toledo } \\
\text { VIII }\end{array}$ & Sí & Sí & Recesvinto \\
\hline 16 & 655 & $\begin{array}{c}\text { Concilio de Toledo } \\
\text { IX }\end{array}$ & Sí & Sí & Recesvinto \\
\hline
\end{tabular}




\begin{tabular}{|c|c|c|c|c|c|}
\hline 17 & 656 & $\begin{array}{c}\text { Concilio de Toledo } \\
\text { X }\end{array}$ & Sí & No & Recesvinto \\
\hline 18 & 666 & Concilio de Mérida & No & No & - \\
\hline 19 & 675 & $\begin{array}{c}\text { Concilio de Toledo } \\
\text { XI }\end{array}$ & No & No & Wamba \\
\hline 20 & 675 & Concilio de Braga III & No & No & Wamba \\
\hline 21 & 681 & $\begin{array}{c}\text { Concilio de Toledo } \\
\text { XII }\end{array}$ & Sí & Sí & Ervigio \\
\hline 22 & 683 & $\begin{array}{c}\text { Concilio de Toledo } \\
\text { XIII }\end{array}$ & Sí & Sí & Ervigio \\
\hline 23 & 684 & $\begin{array}{l}\text { Concilio de Toledo } \\
\text { XIV }\end{array}$ & No & Sí & Ervigio \\
\hline 24 & 688 & $\begin{array}{c}\text { Concilio de Toledo } \\
\text { XV }\end{array}$ & Sí & Sí & Égica \\
\hline 25 & 691 & $\begin{array}{c}\text { Concilio de Zaragoza } \\
\text { III }\end{array}$ & No & Sí & Égica \\
\hline 26 & 693 & $\begin{array}{c}\text { Concilio de Toledo } \\
\text { XVI }\end{array}$ & Sí & Sí & Égica \\
\hline 27 & 694 & $\begin{array}{c}\text { Concilio de Toledo } \\
\text { XVII }\end{array}$ & Sí & Sí & Égica \\
\hline
\end{tabular}

Desde el año 589 (fecha del primer Concilio con presencia del rey) hasta el año 694 (data de las últimas actas conservadas) se oficiaron veintisiete asambleas, de las cuales trece fueron generales y dieciséis contaron con participación regia, menos de una cuarta parte de las estipuladas por la norma eclesiástica vista. El bajo número de celebraciones conciliares ha sido considerado por una parte de la historiografía como la victoria del poder laico sobre el eclesiástico, ya que si los reyes concurrían a estas asambleas quedaban supeditados a las decisiones del clero y de los grandes del reino. Adoptamos otra opinión, como ya anunciamos. Aquel dato puro en sí ya es indicativo de un sistema político institucionalmente 
débil. En el cuadro siguiente asentamos el periodo de gobierno de los reyes que profesaron el catolicismo, las revueltas a las que se enfrentaron con éxito y las que no y los concilios celebrados bajo su mandato. Consideramos que existió una correlación muy estrecha entre las crisis de gobernabilidad plasmadas en las revueltas aristocráticas contra el centro, personificado en el rey, los problemas de legitimación regia que conllevaban estos conflictos y la capacidad de celebrar concilios.

Cuadro 3

\begin{tabular}{|c|c|c|c|}
\hline $\begin{array}{l}\text { Periodo } \\
\text { de } \\
\text { gobierno }\end{array}$ & Rey & Revueltas & Concilios celebrados \\
\hline $586-601$ & Recaredo I & $\begin{array}{l}\text { Sufrió cuatro sublevaciones: en los } \\
\text { años } 587,588,589 \text { y } 590 . \text { Ninguna fue } \\
\text { exitosa. }\end{array}$ & $\begin{array}{l}589 \text { Concilio de Toledo III y } \\
\text { seis provinciales }(589,590, \\
592,597,598,599)\end{array}$ \\
\hline $601-603$ & Liuva II & En el año 603 asesinado. & $\begin{array}{l}\text { No se registran y/o } \\
\text { conservan. }\end{array}$ \\
\hline $603-610$ & Witerico & Asesinado. & $\begin{array}{l}\text { No se registran } y / o \\
\text { conservan. }\end{array}$ \\
\hline $610-612$ & Gundemaro & No se registran. & $\begin{array}{c}\text { Decreto del rey Gundemaro, } \\
\text { año } 610 .\end{array}$ \\
\hline $612-621$ & Sisebuto & No se registran. & $\begin{array}{c}\text { Dos concilios provinciales } \\
\text { de los años } 614 \text { y } 619 .\end{array}$ \\
\hline 621 & Recaredo II & $\begin{array}{l}\text { Depuesto en el levantamiento del año } \\
\qquad 621 .\end{array}$ & $\begin{array}{l}\text { No se registran y/o } \\
\text { conservan. }\end{array}$ \\
\hline $621-631$ & Suintila & $\begin{array}{l}\text { Objetivo de la revuelta de Geila. } \\
\text { Sufrió el levantamiento exitoso de } \\
\text { Sisenando. }\end{array}$ & $\begin{array}{l}\text { No se registran } y / o \\
\text { conservan. }\end{array}$ \\
\hline
\end{tabular}




\begin{tabular}{|c|c|c|c|}
\hline $631-636$ & Sisenando & No se registran. & $\begin{array}{c}\text { Concilio de Toledo IV, año } \\
633\end{array}$ \\
\hline $636-639$ & Chintila & Sin datos concretos. & $\begin{array}{l}\text { Dos concilios toledanos, } \\
\text { años } 636 \text { y } 638 .\end{array}$ \\
\hline $639-642$ & Tulga & En el 642 depuesto. & $\begin{array}{l}\text { No se registran y/o } \\
\text { conservan. }\end{array}$ \\
\hline $642-653$ & Chindasvinto & No se registran. & $\begin{array}{l}\text { Concilio de Toledo VII, año } \\
646 .\end{array}$ \\
\hline $649-672$ & Recesvinto & Aplastó el levantamiento del año 660. & $\begin{array}{l}\text { Tres concilios toledanos } \\
\quad(653,655 \text { y } 656) .\end{array}$ \\
\hline $672-680$ & Wamba & $\begin{array}{l}\text { Objetivo de un levantamiento no } \\
\text { exitoso en el año } 672 \text {. Depuesto en el } \\
\text { año } 680 .\end{array}$ & $\begin{array}{l}\text { Concilio de Toledo X, año } \\
675 \text { y Concilio de Braga III, } \\
\text { año } 675 .\end{array}$ \\
\hline $680-687$ & Ervigio & No se registran. & $\begin{array}{l}\text { Tres concilios toledanos } \\
\quad(681,683 \text { y } 684) .\end{array}$ \\
\hline $687-702$ & Égica & $\begin{array}{l}\text { Levantamiento no exitoso en el año } \\
693 .\end{array}$ & $\begin{array}{l}\text { Tres concilios toledanos } \\
(688,693 \text { y 694) y el } \\
\text { Concilio de Zaragoza III. }\end{array}$ \\
\hline $700-710$ & Witiza & Se enfrentó a Rodrigo. & $\begin{array}{c}\text { Concilio de Toledo XVIII, } \\
\text { año } 702 \text { (actas no } \\
\text { conservadas) } \\
\text { No se registran y/o } \\
\text { conservan otros. }\end{array}$ \\
\hline $710-$ & Agila II & Guerra contra Rodrigo. & $\begin{array}{l}\text { No se registran y/o } \\
\text { conservan. }\end{array}$ \\
\hline $710-711$ & Rodrigo & $\begin{array}{c}\text { Enfrentado a la facción de Witiza. } \\
\text { Derrotado por los árabes. }\end{array}$ & $\begin{array}{l}\text { No se registran y/o } \\
\text { conservan. }\end{array}$ \\
\hline
\end{tabular}


Durante el reinado de Recaredo tuvieron lugar el Concilio de Toledo III y varios concilios provinciales en los cuales se trataron cuestiones de la Iglesia. Recaredo y su conversión al catolicismo despertaron la antipatía de varios grupos aristocráticos arrianos que manifestaron su descontento protagonizando una seguidilla de revueltas ${ }^{405}$; la última de estas sucedió en el año 599 y el primer rey católico murió en el año 601 —a la vez estos episodios se convirtieron en un obstáculo para convocar otro concilio general antes de morir-. A partir de Liuva II, se inauguró un periodo en el cual se celebraron o nos quedaron constancia de tres concilios. Solo el Concilio de Toledo $<$ sub Gundemaro rege $>$ del año $610^{406}$ contó con la intervención regia. Los otros dos concilios son provinciales. En el primero (Concilio de Egara del año 614) se confirmó el Concilio de Huesca del $599^{407}{ }_{1}$ y en el Concilio de Sevilla II de 619 se trató problemas de límites entre sedes eclesiásticas; se registró la participación de dos varones ilustres: Sisiclo rectore rerum publicum y Suanila rectore rerum fiscalium ${ }^{408}$; en ambos concilios provinciales el nombre del rey Sisebuto aparece en los encabezados de apertura de las actas, pero no se observa su participación directa ni los asuntos por tratar se vinculan con el dominio regio o con conflictos intra-aristocráticos laicos ${ }^{409}$.

Sisenando llegó al poder en el año 631 destronando a Suintila, y tuvo dificultades para imponerse en el reino ${ }^{410}$; por tal motivo en el 633 convocó al IV Concilio de Toledo con el fin de legitimarse como rey ${ }^{411}$. Bajo el reinado de Chintila se celebraron el V Concilio de Toledo (año 636) y el VI (año 683); en ambos los temas más destacados se relacionan con la protección del rey y su familia. La sensación de inseguridad y de fragilidad institucional que transmiten los cánones de este conjunto de Concilios es indiscutible. Volveremos sobre la

\footnotetext{
405 Ver pp. 147 y ss.

406 Gundemaro determinó, a través de un decreto real que obtuvo su confirmación en un documento conocido como Constitutio Carthaginensium sacerdotum, que Toledo no fuera solo la capital de Carpetaia, sino también de la provincia Cartaginense en su totalidad. Concilios, pp. 403-409.

González Blanco pone en duda la autenticidad de este documento. GonZÁlEz BLANCO, A.: "El decreto de Gundemaro y la historia del siglo VII”, en Los visigodos. Historia y civilización. Antigüedad y cristianismo, Murcia, 1986. Codoñer lo considera verdadero. CoDOÑER, C. (coord.): La Hispania visigótica y mozárabe: dos épocas en su literatura..., p. 322.

407 Concilios, Egara, año 614, p. 162.

408 Ibidem, Sevilla II, año 619, c. I, p. 163.

${ }^{409}$ Ibidem, Egara, año 614, encabezado, p. 162; Sevilla II, año 619, encabezado, p. 163.

${ }^{410}$ GARCÍA MORENO, L.A.: Historia de la España visigoda ..., p. 156.

${ }^{411}$ LORING, Ma. I., PÉREZ, S. Y FUENTES, P.: La Hispania tardorromana y visigoda. Siglos V-VIII..., p. 179.
} 
importancia de estos más adelante. El hijo de Chintila, Tulga, luego de tres años de gobierno fue depuesto y tonsurado en el año 642 por una facción encabezada por Chindasvinto.

Pasados ocho años del último Concilio, Chindasvinto convocó al VII Concilio de Toledo, cuya particularidad radicó en que el primer canon estuvo destinado exclusivamente a condenar a los traidores al rey. Anteriormente observamos que algunas de las acciones de gobierno de este rey coincidieron con el espíritu condenatorio de este Concilio. Sus sucesores -Recesvinto, Wamba, Ervigio y Égica - sufrieron revueltas aristocráticas o fueron objeto de la presión de distintos grupos que se vieron perjudicados en las decisiones tomadas. Los cuatro reyes propiciaron la celebración de las asambleas conciliares con el fin de tratar principalmente asuntos que atentaban contra su gobernabilidad y, a la vez, legitimarse en el poder. Por lo tanto, consideramos que, si los reyes en ciertas ocasiones debieron refrendar sus decisiones y en otras someter a voluntad de la aristocracia reunida cuestiones de su gobierno, su potestad, en esos momentos, estuvo condicionada por los magnates, siendo esto un factor que corroía la autoridad regia. Otras veces los mismos que ocupaban la máxima jefatura del reino propiciaban la reunión. Enumeramos a continuación los principales motivos para ello:

i. buscar el reconocimiento legal y por escrito del reinado por parte de los obispos y de los primados del palacio (fundamentalmente si el ascenso al trono se había realizado de forma irregular), ya que en las actas conciliares se destacaban las fórmulas de entronización: en los encabezados figuran la ciudad y la iglesia sedes de la celebración, la fecha y año de reinado del monarca, y el nombre de este siempre está acompañado de titulaturas enaltecedoras de su persona ("gloriosi""412, "serenisimi et orthodoxi" "413, "regni excellentissimi" ${ }^{414}$ ). Estos títulos y tratamientos protocolarios distintivos fueron tomados del poder imperial, y luego de la conversión al catolicismo, evocaban también a la imaginería cristológica ${ }^{415}$.

\footnotetext{
412 Concilios, Toledo XIV, año 684, encabezado, p. 441.

${ }^{413}$ Ibidem, Toledo XV, año 688, encabezado, p. 449.

${ }^{414}$ Ibidem, Toledo XIII, año 694, encabezado, p 411.

415 BArroso CABrera, R., Morín DE PABlos, J: VelÁzQuez Soriano, I.: "La imagen de la realeza en el reino visigodo de Toledo a través de la iconografía y la epigrafía”, Zona arqueológica, 11, 2009, p. 490.
} 
ii. consensuar acciones de su gobierno, ya realizadas o futuras, que demandasen la aprobación de los palatinos y prelados. Esto se evidencia, por ejemplo, en el momento en que Recesvinto hizo tratar en asamblea conciliar su postura de reducir las penas a los expatriados y traidores del rey Chinsdavinto $(642-653)^{416}$. La asamblea, luego de deliberar y acudir a las santas escrituras, decidió quebrantar los juramentos acordando con la postura del monarca, porque desearon más “(...) anatema ese Christo pro fratibus nostris, quam perdurare crudelibus in delictis" ${ }^{" 417}$. En el año 687 Ervigio designó como sucesor a su yerno Égica, obligándolo mediante juramento a proteger a la familia y su patrimonio ${ }^{418_{1}}$; en el año 688 se convocó al XV Concilio de Toledo, allí Égica pidió la eximición de los juramentos realizados por él y por la asamblea conciliar del año $683^{419}$.

iii. condenar a los enemigos políticos, principalmente después de triunfar sobre una revuelta; ejemplo de esto son los Concilios celebrados bajo los auspicios de Sisenando, Chintila, Chindasvinto, Recesvinto, Wamba y Égica.

iv. establecer vínculos con alguna facción de la aristocracia que había sido condenada por alguno de los reyes anteriores mediante el indulto y la restitución de sus bienes, en la medida que no afectara a los partidarios de rey gobernante. Ejemplos de esto son los perdones decretados por Sisenando, Recesvinto, Ervigio y Égica.

Es evidente que si bien los concilios fueron un instrumento de gobierno y un medio para disciplinar a la Iglesia y a la arisca aristocracia - como sostiene parte de la historiografía - también se erigieron como uno de los espacios de construcción del poder y de la autoridad regia, como propone Díaz Martínez cuando enuncia que en los concilios el rey encontraba la legitimación y protección necesaria para gobernar ${ }^{420}$. En estas reuniones, que funcionaban como verdaderas asambleas generales del reino cuyos fallos los dictaminaba el rey, o los magnates o de común acuerdo, se dirimía la correlación de las fuerzas políticas del momento; se construía el consenso aristocrático de manera permanente.

\footnotetext{
416 Concilios, Toledo VIII, año 653, p. 260 y ss.

417 Ibidem, Toledo VIII, año 653, c. III, p. 277.

418 Ibidem, Toledo XV, año 688, pliego regio, p 465. En este concilio se trascribió el juramento realizado por Égica a Ervigio con el fin de someterlo a pericia.

${ }^{419}$ Ibidem, Toledo XV, año 688, acta conciliar, pp. 465 y 466.

${ }^{420}$ DíAz MARTíneZ, P.C.: Hispania tardoantigua y visigoda..., p. 412.
} 
Los Concilios transmiten una sensación de inseguridad constante que fortalece la idea de la incertidumbre que generó el desorden político. Durante gran parte del siglo VII se promulgaron cánones que incitaron a guardar los juramentos de fidelidad y protección sobre la persona del príncipe ${ }^{421}$. La primera de las veces que se dispuso una norma conciliar de esta naturaleza fue en el Concilio de Toledo IV del año 633. Con el fin de fortalecer la situación de los reyes y dar estabilidad al reino (est pro robore nostrorum regum et stabilitate gentis Gothorum ${ }^{422}$ ) se denunció a aquellos que habían roto con sus acciones la fidelidad prometida con juramento a sus reyes (fidem sacramento promissam ${ }^{423}$ ) y, como consecuencia, habían ofendido a Dios; asimismo se instó a que no preparasen conjuras, arrebatasen el trono ni encendieran sediciones civium. Por lo tanto, reclamaron que no existiera la infidelidad, la perfidia del corazón ni el crimen del perjurio. También los reunidos sentenciaron tres veces que aquellos que violasen con maniobras o conjuras el juramento pronunciado a favor de la vida del rey y la prosperidad del pueblo godo, o el que intentase matar al rey o socavar su poder o usurpar el trono, sería considerado como anatema y quedaría expulsado de la comunión de la Iglesia. El Concilio de Toledo V, del año 636, repitió la fórmula, y en el VI, en dos cánones, los reunidos agregaron que mientras el rey estuviera vivo, que nadie, laico o eclesiástico, preparase su candidatura al trono con acciones o con consejos en desobediencia del rey ni halagando o persuadiendo en su empresa a otros para que se comprometiesen con su cometido; y aquel que pretendiera la muerte del rey o atentara contra su vida, o quisiera arrebatar el trono o lo usurpara tiránicamente, o complotando contra el rey agrupara en su círculo a un grupo de conjuradores, sería considerado anatema. En el año 646, bajo reinado de Chindasvinto, el canon primero del séptimo concilio toledano dictó que aquellos hombres de la Iglesia que participaran o intentaran una conjura contra el pueblo de los godos, la patria o el rey, serían desposeídos de sus dignidades para que otros ocupen sus puestos y serían excomulgados hasta el día de su muerte; además se previó la incautación de sus bienes, dejando abierta la posibilidad de que el rey restituyera por su voluntad parte de sus bienes sin sobrepasar la vigésima parte de los mismos; el Concilio de Toledo X del año 656 volvió

\footnotetext{
${ }^{421}$ Concilios, Toledo IV, año 633, c. LXXV, p. 217; Toledo V, año 636, c. IV, p 228 y c.V, p. 229; Toledo VI, año 638, c. XVII, p. 244; Toledo VII, año 646, c. I, p. 249; ToledoX, año 656, c. II, p. 310; Toledo XVI, año 693, c. X, p. 509.

${ }^{422}$ Ibidem, Toledo IV, c. LXXV, p. 217.

${ }^{423}$ Idem.
} 
a repetir los castigos a estos crímenes en un canon de estructura similar. Hacia fines del siglo VII, Égica convocó un concilio en Toledo donde, entre otros asuntos, se trató el intento de derrocamiento por parte del obispo Sisberto. Seguido al canon que proclamó el castigo aplicado al traidor, se decretó uno que lleva como título "De his qui iuramenti sui profanatores extitisse noscuntur" ${ }^{424}$ que dice cualquier sujeto, cual sea su condición social, que violase su juramento realizado al rey debería ser castigado, y tanto aquel como sus descendientes quedarían excluidos de toda dignidad del palacio y formarían parte de la servidumbre del fisco por toda la perpetuidad.

Asimismo, varios son los cánones destinados a salvaguardar la descendencia de los reyes $^{425}$. Al realizar el análisis de estos se advierte que la estructura discursiva fue siempre similar: se exhortó a que ningún habitante del territorio godo realizase daño a la reina, ni a los hijos ni a sus cónyuges; que no fuesen expropiados ni expulsados de sus bienes; que no sufriesen por violencia la señal de la tonsura y que las mujeres no fuesen obligadas a vestir el hábito religioso.

Las modalidades descritas por las cuales se cometía perjurio contra el rey y su descendencia no fueron en todos los casos escenarios hipotéticos; al contrario, encontramos varias advertencias de estos cánones que se produjeron en situaciones concretas, como veremos luego.

En primer lugar, la práctica de la tonsura ha sido un medio para anular el poder de un rey o sus descendientes que pudieron presentarse como claros sucesores, pues las leyes prohibieron el ascenso a la investidura regia a un canónigo ${ }^{426}$. Tulga y Wamba recibieron la marca clerical, la cual los anuló como actores políticos activos laicos, y su consecuencia más dramática resultó la abolición de toda posibilidad de volver al ruedo para ocupar la máxima jefatura del reino.

Otra forma de expulsar del trono de forma definitiva a los reyes no deseados, y a su descendencia, fue incautando sus bienes, es decir, invalidando su posición económica y, como consecuencia, su capacidad de construir alianzas. Éste fue el destino decidido para Suintila en el cuarto Concilio de Toledo convocado por el promotor de su destronamiento,

\footnotetext{
${ }^{424}$ Concilios, Toledo XVI, año 693, c.X, pp. 509-510.

${ }^{425}$ Ibidem, Toledo V, año 636, c. II, p. 227; Toledo VI, año 638, c.XVI, p. 243; Toledo XIII, año 683, c. IV, p. 419-420; Toledo XVI, año 693, c.VIII; Toledo XVII, año 694, c. VII.

${ }^{426}$ Concilios, Toledo VI, año 638, c. XVII, pp. 244 y ss.
} 
Sisenando ${ }^{427}$. Con esta medida, Sisenando se aseguró que Suintila y su hijo Ricimiro, quien según Isidoro de Sevilla había sido asociado al trono por su padre ${ }^{428}$, no tuviesen ninguna posibilidad de resurgir y competir por el trono.

Las endémicas revueltas nobiliarias registradas, las confabulaciones secretas, las traiciones, los intentos de regicidios y los destronamientos exitosos — que tantas veces fueron sancionados como hechos imperdonables - demuestran que fueron situaciones reales las que los reyes debieron enfrentar. Vemos en la violación de estas sanciones un signo de la fragilidad política de los reyes, pues quebrantar los preceptos ordenados fue una regla más que una excepción.

Los hechos registrados nos llevan a las primeras conclusiones. En primer lugar, observamos que los cánones sobre la salvaguarda de la figura regia fueron promulgados en los Concilios propiciados por reyes que ascendieron al trono a través de una revuelta abierta o una conspiración, o por aquellos que fueron objetivos de atentados no exitosos, como podemos ver en los datos entrecruzados en el cuadro número tres. A través de estas normas los reyes se afirmaban como autoridad ante todos los presentes, confirmando la idea más expuesta sobre los Concilios como espacio de construcción y legitimación del poder regio. Asimismo, advertimos que los reyes que propiciaron la promulgación de los cánones relacionados con la protección de la descendencia de los reyes fueron sucedidos por sus hijos, (Tulga ascendió a la dignidad de rey a la muerte de Chintila y Witiza a la de Égica) o yernos (como es el caso de Égica que sucedió a su suegro Ervigio); de hecho, fue Ervigio quien extendió el pedido de protección para la familia política ${ }^{429}$. Creemos que los reyes que promovieron los cánones de protección tenían el plan de convertir en herederos a algún miembro de su familia - como de hecho aconteció- y a través de las promulgaciones intentaron vincular a la aristocracia laica y eclesiástica para que brindasen una protección extra a los futuros mandatarios.

Este conjunto de escritos conciliares muestra, por un lado, la fragilidad política institucional, la oscilación del poder regio y la incertidumbre que rodeaba a los reyes y, por otro, cómo los reyes se afirmaban en el trono vinculándose a los grandes del reino a través

\footnotetext{
${ }^{427}$ Ibidem, Toledo IV, año 638, c. LXXV, p. 221.

${ }^{428}$ ISID. Hist. Goth., p. 279.

${ }^{429}$ Concilios, Toledo XIII, año 683, c. IV, pp. 419-420.
} 
de los cánones que imponían fuertes sanciones. Aquí existe un proceso cuya lógica está constituida por una dialéctica de amenazas y sanciones: los ataques potenciales que los reyes percibieron tuvieron su intento de ser contrarrestados con la formulación de sanciones. Estamos frente a una potestad regia condicionada no por la turbulenta aristocracia, sino por la exigua objetividad del poder político. En el próximo capítulo estudiamos la naturaleza reciprocitaria de la dinámica de la relación entre la realeza y la clase aristocrática, cuyo carácter explica las limitaciones del dominio regio y su permanente oscilación.

Si bien a través de estas sanciones y juramentos los reyes se legitimaron, no implicó que la aristocracia en su conjunto respetase al rey gobernante ni aseguró una estabilidad para los venideros; al contrario, cada rey debía legitimarse, edificar su autoridad y afianzar sus vínculos. El poder político construido por sus antecesores no se heredaba.

El conjunto de datos observados nos alienta a seguir buscando indicios sobre la fragilidad política. Por lo tanto, ahora analizaremos las formas de acceso al trono, problema íntimamente ligado a lo visto en los párrafos anteriores y que, además, arroja más luz sobre nuestros planteos, pues consideramos que la imposibilidad de cristalización de las instituciones constituye también un indicio de fragilidad política.

\section{El acceso al trono: fórmulas legales y formas legítimas}

Entre los visigodos existió una estructura legal que brindaba un marco legítimo a la autoridad del rey. De hecho, existió un conjunto de leyes y tradiciones que señalaban la manera de elegir a los reyes y, a la vez que fijaban criterios de selección, establecieron expectativas en torno al actuar regio.

Luego de la batalla en Vouillé y el posterior asentamiento en las tierras hispanas ${ }^{430}$, la aristocracia goda reaccionó negativamente ante la posibilidad de que una familia aclamase para sí la exclusividad de la corona. De este modo, la elevación de un personaje encumbrado a rey se realizaba mediante la votación de sus pares, según la tradición. Sin embargo, no conocemos que existiera una regla fija en la sucesión. Recién en el IV Concilio de Toledo habían comenzado a establecerse las normas para un legítimo proceso electivo ${ }^{431}$. En el V

\footnotetext{
${ }^{430}$ Para un análisis del fin del reino de Tolosa y el proceso de avance visigodo sobre el territorio hispano ver: VALVERDE CASTRO, $\mathrm{M}^{\mathrm{a}}$.R.: Ideología, simbolismo y ejercicio del poder real en la monarquía visigoda... y JIMÉNES GARNICA, A. M.: Nuevas Gentes, Nuevo Imperio...

${ }^{431}$ Concilios, Toledo IV, año 633, c. LXXV, p. 217.
} 
Concilio de Toledo, del año 636, se proclamó que aquel que no fuese llevado al ápice del honor por la decisión de todos o por su origen godo sería excomulgado y anatematizado ${ }^{432}$. El VI Concilio precisó que muerto el rey:

"Rege vero defuncto nullus tyrannica praesumtione regnum adsummat, nullus sub religionis habitu detonsus aut turpiter decalvatus aut servilem originem trahens vel extraneae gentis homo, nisi genere Gothus et moribus dignus provehatur ad apicem regni" ${ }^{433}$

En el VII Concilio de Toledo se decretó que la elección de los reyes se debería realizar en la urbe regia o en el lugar donde hubiera muerto el rey anterior, con el beneplácito de los obispos y de los aristócratas del palacio para evitar el acceso al trono por medio de una conspiración o una revuelta ${ }^{434}$. De esta manera se intentó crear un marco institucional para así evitar conflictos en torno a la dignidad regia, que tuvo como resultado un escaso éxito, como hemos visto en el cuadro número uno.

Esta serie de documentos repasados y las distintas noticias sueltas sobre el acceso al trono de los reyes conforman el principal conjunto documental que los especialistas emplean para tratar esta problemática y brindar sus puntos de vista.

Torres $^{435}$, Sánchez Albornoz ${ }^{436}$ y García Gallo ${ }^{437}$ defienden la existencia de un sistema electivo de los reyes visigodos, y proponen que aquellos que accedieron al trono por vías distintas a la elección (es decir, por herencia, asociación o usurpación) se legitimaron en el poder acudiendo a la aclamación posterior o reconocimiento de la aristocracia. Orlandis entiende que la asociación al trono, la herencia y la elección fueron todos procedimientos sucesorios válidos ${ }^{438}$.

De opinión contraria a lo sostenido por estos autores tradicionales encontramos a King, Barbero y Vigil, Díaz Martínez, Valverde Castro y García Moreno. Barbero y Vigil

\footnotetext{
432 Ibidem, Toledo V, año 636, c. III, p. 228.

${ }^{433}$ Ibidem, Toledo VI, año 638, c. XVII, pp. 238 y 239.

${ }^{434}$ Ibidem, Toledo VIII, año 653, c. X, pp. 282 y 283.

435 TORRes LÓPEZ, M.: "El estado visigótico", Anuario de Historia del Derecho Español, T.III, 1926, p. 129.

436 SÁnChez Albornoz, C.: "El senatus visigodo. Don Rodrigo, rey legítimo de España", Cuadernos de Historia de España, Buenos Aires, 1 947, p. 76.

${ }^{437}$ García Gallo, A.: Manual de historia del derecho español, vol 1, Madrid: Artes Gráficos, 1975, p 536.

${ }^{438}$ ORLANDIS, J.: "La sucesión al trono en la monarquía visigoda", Estudios Visigóticos, 3, Roma, Madrid, 1962, pp. 57-102.
} 
admiten que entre los visigodos existió una evolución en el principio de sucesión que era concordante con las estructuras socioeconómicas de cada periodo. Entre los siglos IV y V "prevalece un tipo de realeza derivada de la sociedad gentilicia"439; los reyes estaban vinculados por diferentes vías al clan regio de los Baltos. El proceso de diferenciación social alimentado por la apropiación de bienes inmuebles y del dominio ejercido sobre los hombres dependientes afianzó el carácter de los reyes haciendo que los vestigios gentilicios desapareciesen. En los siguientes años, diferentes miembros de la "nobleza latifundista" 440 y militar visigoda se impusieron en el trono por la fuerza hasta que tomaron medidas para "llegar a una solución que hiciera posible la supervivencia del Estado y la suya propia como el grupo social dominante dentro de él" ${ }^{441}$. La solución que encontraron fue la elección del rey realizada por la aristocracia en común acuerdo con el beneplácito de la Iglesia que convertía a los reyes en seres ungidos. Sin embargo, señalan estos autores, existió una fuerte contradicción entre la forma electiva de la monarquía y las fuertes relaciones de dependencia que imperaban en la sociedad visigoda. Por lo tanto, hacia el último periodo del reino hubo cambios en la forma de trasmitir el poder regio; Barbero y Vigil concluyen que el sacramento de la unción — que significó que la dignidad real provenía de la gracia de $\operatorname{Dios}^{442}$ - y la práctica de la asociación al trono realizada por los últimos reyes llevaron a "la institucionalización de una monarquía feudal, patrimonial y hereditaria, de acuerdo con las realidades socioeconómicas" ${ }^{443}$

Por su parte, King cuestiona el principio electivo de los reyes visigodos y defiende que el mecanismo legítimo por el cual un aristócrata se encumbraba en lo más alto de la esfera política era por la fuerza ${ }^{444}$, en sus propias palabras:

\footnotetext{
${ }^{439}$ BARBERO A. y VIGIL, M.: La formación del feudalismo en la Península Ibérica ..., p. 199.

${ }^{440}$ Idem.

${ }^{441}$ Idem.

442 Ibidem, p. 197.

${ }^{443}$ Ibidem, p. 200.

${ }^{444}$ Céline Martin sostiene que "La succession au trône est aisni le résultat d'un affrontement, pacifique ou non, au sein de l'aristocratie, qui débouche su la mise, à l'ecart de certains groupes au profit de ceux dont le candidat est vainqueur", MARTIN, C.: "Des fins de règne incertaines: répression et amnistie des groupes aristocratiques dans le royaume de Tolède (deuxième moitié du VIIe s.) ", en BourGARD, F., FELLES, L. Y LE JAN, R. (eds.) : Les élites au haut Moyen Âge. Crises et renouvellements, Turnhout: Brepols, 2006, p. 222.
} 
"Aunque el estado visigodo es reputado por su monarquía electiva, el hecho es que pocos gobernantes del siglo séptimo llegaron al poder real como resultado exclusivo de un proceso electivo stricto sensu: es más exacto hablar de un <trono por ocupación>, ya que la asociación previa, la designación y la simple usurpación tenían todas un papel significativo"445

Díaz Martínez y Valverde Castro adoptan como válida la opinión expresada por King y siguen bien de cerca la propuesta de Barbero y Vigil, en palabras del primero:

“(...) los procedimientos al margen de la elección no se consideraron nunca ilegítimos, salvo que mediase la violencia, y aun así los concilios confirmaron a los reyes en cualquier circunstancia (...). La elección podía no ser, en la práctica, más que la aclamación de un victor" ${ }^{446}$.

Como señalamos en el recuento historiográfico, ambos autores acuerdan que no existió un principio institucional respetado que determinase la forma de sucesión al trono, el que llegaba al ápice del poder era aquel que triunfaba en la lucha desatada entre la aristocracia y los reyes ${ }^{447}$. Opinan que la incapacidad regia de imponer una forma institucional de sucesión ha sido consecuencia de la derrota ante la fuerte nobleza feudal visigoda.

Por su lado, García Moreno —utilizando como principal soporte empírico los elementos onomásticos de los nombres y otras fuentes de noticias más tradicionalespropone que la monarquía visigoda no fue electiva, y que la más alta dignidad del reino fue ocupada por miembros pertenecientes a unas pocas familias, no más de cinco, y muy relacionadas entre ellas ${ }^{448}$.

\footnotetext{
${ }^{445}$ KING, P.D.: Derecho y sociedad en el reino visigodo..., p. 43.

${ }^{446}$ DíAz MARTíNEZ, P.C.: "Rey y poder en la monarquía visigoda", Iberia, 1, 1998, p. 189. DíAz MARTínEZ, P.C.: Hispania tardoantigua y visigoda ..., p. 414-415.

${ }^{447}$ VALVERDE CASTRO, Ma.R.: Ideología, simbolismo y ejercicio del poder real en la monarquía visigoda: un proceso de cambio..., p. 281. Castellanos opina de similar modo: "La realeza no estaba dotada de unos mecanismos de sucesión regia que debieran ser acatados por los magnates del reino, en constante competencia por la ocupación de tan codiciado puesto. Sin tales mecanismos de sucesión, eran las coyunturas propias de cada momento las que determinaban quién sería el próximo en ocupar el poder (...)." CASTELLANOS, S.: Los godos y la cruz. Recaredo y la unidad de Spania..., p. 145.

${ }^{448}$ García Moreno, L. A.: "Prosopography, Nomenclature, and Royal Succession in the Visigothic Kingdom of Toledo “, Journal of late antiquity, vol. 1, 2008, pp. 142-156.
} 
Del breve sumario realizado sobre el problema del acceso al trono, destacamos que los autores contemporáneos no fijan su atención en él y cuando lo hacen, como el caso de Valverde Castro o Díaz Martínez, esgrimen los mismos argumentos dados hace ya varias décadas. Tal vez la propuesta realizada por García Moreno sea la más interesante porque permite abrir nuevas vías de investigación sobre este problema.

Si bien la aristocracia aceptó que el rey fuera la máxima autoridad en el territorio ibérico, se reguló el sistema de elección regia y, al mismo tiempo, existió una teoría edificante del derecho canónico de los reyes a gobernar ${ }^{449}$, en la praxis política cada uno de estos preceptos se violó sistemáticamente. Ninguna tradición o fórmula legal se impuso como forma de acceso al trono; el sistema de sucesión real nunca se objetivó. Es comprensible que en una sociedad donde la dominación política fue inestable sus instituciones también lo hubiesen sido. Pensando así es como podemos comprender que la alternancia entre la asociación, la elección y la usurpación fueran todas formas legítimas (aunque no todas legales) de asumir la investidura regia.

La sistematización de las fuentes indica que la fragilidad del sistema político y la forma alterna del poder político regio constituyeron rasgos estructurales, independientes de los personajes (o personalidades) que ocuparon el solio real. El siglo y medio de existencia de la entidad del reino visigodo estuvo signado por el ritmo de las crisis del dominio regio. Su análisis permite conocer la esencia del objeto de estudio de esta investigación. Las crisis del sistema político fueron manifestaciones de la crisis orgánica de la clase dominante visigoda $^{450}$.

La contradicción entre la teoría política y el trascurso de los hechos fue la manifestación de un fenómeno, el aspecto externo de la dinámica del sistema político visigodo.

Romper el binomio dicotómico "débil -fuerte" establecido por la historiografía para caracterizar al reino visigodo es fundamental para comprender su funcionamiento, pues ambas visiones solo explican la superficie del fenómeno político. Creemos que tanto aquellos que ven un estado débil por los incesantes golpes aristocráticos (las sublevaciones, los regicidios, fragmentación y/o regionalización del poder...), como aquellos que aportan

\footnotetext{
449 Sobre esta cuestión trabajaremos en el capítulo 7.

${ }^{450}$ ASTARITA, C.: "Construcción histórica y construcción historiográfica de la temprana Edad Media".
} 
pruebas del fortalecimiento de la autoridad del rey (emisión monetaria, persecuciones a los enemigos, fortalecimiento ideológico de la figura regia, capacidad fiscal y legislativa, entre otras) están observando algunas de las formas en que se manifestó la esencia de la dinámica política, aunque no la esencia misma. 


\section{Capítulo 5}

\section{REYES Y ARISTÓCRATAS: FIDELIDAD POLÍTICA Y RECOMPENSAS}

En el capítulo anterior constatamos el fenómeno de la fragilidad del sistema político y la oscilación del poder regio como variables de la inestabilidad del dominio político de los reyes y como manifestaciones de la crisis orgánica de la clase dominante. Aquí nos concentraremos en explicar la dinámica del sistema político visigodo, centrándonos en las relaciones intra-aristocráticas.

La evolución política visigoda es analizada desde múltiples puntos de vista y los especialistas difieren largamente en las características que le atribuyen al reino de Toledo. Mientras que para unos el estado visigodo ha sido débil, para otros fue el más próspero dentro del conjunto europeo de la época. Es esta abismal diferencia de opiniones la que nos conduce a proponer un marco de análisis distinto para este problema. Asimismo, la inconsistencia del sistema político visigodo y la violencia intra-aristocrática son objeto de un sinfín de estudios; sin embargo, los argumentos esgrimidos para explicar sus raíces no nos satisfacen completamente, como constatamos en el anterior capítulo. Entonces, para comprender la verdadera naturaleza de la dinámica política realizaremos el siguiente recorrido.

En primer lugar, trabajaremos el concepto de dominación de Weber. Como ya enunciamos, la tipología de dominación carismática y el concepto de carisma constituyen una base desde donde plantear hipótesis sobre la lógica de la dominación política legítima visigoda. 
En un segundo apartado demostraremos que la génesis de la fragilidad política institucional la encontramos en la falta de objetivación de las relaciones políticas desiguales (aunque existía una gran diferencia estamental entre el rey y la aristocracia) y en su naturaleza reciprocitaria. La teoría del don y la noción de Kónigsnähe complementarán las nociones weberianas.

Nota sobre la dominación carismática: análisis del concepto y su utilidad en el estudio de la dinámica de la dominación política de los reyes visigodos

El análisis sobre el problema de la dominación (Herrschaft) es una de las contribuciones más importantes realizadas por Weber. Cierto es que sus estudios estuvieron centrados en descubrir las características específicas de la lógica política en las sociedades capitalistas ${ }^{451}$ y sobre el "desencantamiento del mundo que se produjo con la modernidad" ${ }^{\text {" }}$; sin embargo, sus aportes sobre el tema abrieron variantes analíticas interesantes para reflexionar sobre las sociedades precapitalistas.

Revault d' Allonnes explica que el estudio del término Herrschaft significa en Weber un "verdadero recorrido de la constitución progresiva de la autoridad" 453 y, además, implica entender las formas de dominación y creencias. A partir de esto es que Weber propone el análisis de los tipos de dominación.

Es interesante - e ilumina nuestra investigación - el estudio sobre el término Herrschaft que realiza la autora citada anteriormente. Este término alemán no tiene su equivalente en inglés ni en castellano, por lo tanto, su traducción es compleja. En inglés se utiliza el vocablo rulership para traducir a Herrschaft; se lo emplea desde que Benjamin Nelson, en 1920, prefirió dicho vocablo porque evoca al elemento de la legitimidad y debilita, sin desconocerlo, al elemento de la fuerza ${ }^{454}$; en castellano usualmente se lo traduce como “dominación”, en menor medida como "autoridad" o "poder". El término antagónico de la

\footnotetext{
${ }^{451}$ SERRANO GÓMEZ, E.: Legitimación y racionalización. Weber y Habermas: la dimensión normativa de un orden secularizado, México: Anthropos, 1994, p. 52. Ver también: Aronso, P.: "La centralidad del carisma en la sociología política de Max Weber”, Entramados y perspectivas. Revista de la carrera de sociología, vol. 1, 1, enero-junio 2011, pp. 10- 126.

452 Revault D' Allonnes, M.: El poder de los comienzos. Ensayos sobre la autoridad, Buenos Aires: Amorrortu, 2008, p.152.

453 Ibidem, p. 154.

${ }^{454}$ KUPER, J.: Key Thinkers, past and present, New York: Routledge, 2015, p. 270.
} 
Herrschaft es la Macht, la "fuerza" o la "potencia” (según Revault d' Allonnes o simplemente como "poder" según otros autores), la capacidad de coaccionar y de imponer la voluntad por la violencia. En cambio, el concepto Herrschaft “(...) designa la posibilidad — la probabilidad - que tiene una orden $(B e f e h l)$ de ser obedecida, de encontrar obediencia." ${ }^{455}$. La razón del concepto weberiano es el reconocimiento de la legitimidad, y con ello abre la posibilidad del rechazo o el consentimiento, por eso Revault d'Allonnes concluye:

"La Herrshaft implica a cada instante la posibilidad de su impugnación: la negativa a reconocer su legitimidad, el riesgo de su deslegitimización. Razón por la cual el punto de partida de la construcción weberiana — verdadero recorrido de la autoridad - es la Herrschaft, y no la Macht (...). Es posible, pues, conservar la traducción por <dominación>, a condición de integrar en este término el elemento de la legitimidad, no a título de suplemento, sino de fundamento" $" 456$

El subrayado realizado en el párrafo citado tiene como finalidad destacar que el término dominación incluye a la legitimación, y destacamos su significado más importante: la posibilidad de reconocerlo o rechazarlo. Por lo tanto, estas reflexiones nos permitirán pensar los mecanismos que utilizaron los reyes visigodos para ejercer su dominación política, no solo en este capítulo sino en toda la tesis.

Weber identifica a tres tipos ideales ${ }^{457}$ de dominación legítima: la racional, la tradicional y la carismática. La primera, la racional, es una autoridad legal fundamentada en

\footnotetext{
455 Revault D’ Allonnes, M.: El poder de los comienzos. Ensayos sobre la autoridad..., p. 155.

${ }^{456}$ Ibidem, p. 157.

${ }^{457}$ Válida es la advertencia de que ninguno de los tipos ideales de dominación los encontramos en estado puro en las realidades históricas, pero sí puede presentarse cada uno en grados diferentes sin necesidad de excluirse mutuamente; de hecho, se construyen para la comparación. Un tipo ideal es "un concepto límite con el que confrontamos la realidad para clarificar el contenido empírico de ciertos elementos esenciales" Ibidem, p.162. Emerich Francis declara que la mayor contribución weberiana a la metodología sociológica fue el concepto de tipo ideal, concepción extraída de la ciencia histórica e introducida en la sociología con el fin de comprender. EMERICH, F.: "Cultura y sociedad en la sociología de Max Weber”, Congreso de Sociología de la ciudad de Hiedelberg auspiciado por la Universidad Ludwing-Maximilian en 1964. Conferencia dictada en Munich por motivo del centenario del nacimiento de Weber. Este comprender es la premisa continuada por la investigación empírica, como nos dice Emerich Francis "el esquema es: comprensión- tipo ideal- relación causal- leyes empíricas.” EMERICH, F.: “Cultura y sociedad en la sociología de Max Weber” ... El uso de los tipos ideales en la labor analítica histórica cumple con el fin concebido por Max Weber: permite constatar en qué grados la
} 
la legalidad escrita con anterioridad a la misma; en la autoridad tradicional la legitimidad está dada por una tradición remota; y la autoridad carismática radicada en el carisma, en una cualidad extraordinaria y extracotidiana de una personalidad ${ }^{458}$. Del vasto planteo de Weber sobre el problema de la dominación, sobre la causa de que algunos logren el mando y otros se sometan, y sobre las consideraciones acerva la relación entre dominados y dominantes, nos interesa rescatar la operatividad del concepto de dominación carismática.

La legalidad de la dominación carismática reside en el reconocimiento de los adeptos hacia el líder portador del carisma, de esa cualidad extraordinaria y única. La relación entre el mandatario y los seguidores está unida a través de una creencia común. El líder es portador de un carisma genuino fuera de lo cotidiano, lo cual torna a la dominación inestable pues

“(...) si falta de un modo permanente la corroboración, si el agraciado carismático parece abandonado de su dios o de su fuerza mágica o heroica, le falla el éxito de modo duradero $y$, sobre todo, si su jefatura no aporta ningún bienestar a los dominados, entonces hay la probabilidad de que su autoridad carismática se disipe" ${ } 459$.

Weber considera que el carisma puede objetivarse cuando se acepta socialmente, cuando se establece como un factor de durabilidad social ${ }^{460}$. Esta relación de carácter efímero se torna perenne; la rutinización del carisma sucede cuando tiende a racionalizarse (se convierte en una dominación racional) o tradicionalizarse (se convierte en una dominación tradicional), o ambas en distintas fases. Según la propuesta weberiana el carisma tiene el potencial de trasmutar a formas impersonales.

La transformación suscitada radica en los intereses materiales o ideales de los seguidores de mantener su propia posición con base en una durable cotidianeidad ${ }^{461}$, esto se logra dando un tinte carismático a su propio sistema de dominación. El problema surge ante

sociedad observada se acerca o se aleja del tipo ideal para determinar los elementos empíricos propios, y a su vez permite la elaboración de hipótesis en torno al objeto de estudio específico: SÁNCHEZ DE PUERTA TRUJILLO, F.: "Los tipos ideales en la práctica: significados, construcciones, aplicaciones", EMPIRIA. Revista de Metodología de Ciencias Sociales, $\mathrm{n}^{\mathrm{o}}$ 11, enero-junio, 2006, $\mathrm{p} 16$.

${ }^{458}$ WeBer, M.: Economía y Sociedad, México: Fondo de Cultura Económica, 1987, pp-170-173.

${ }^{459}$ Ibidem, p 194.

${ }^{460}$ ReVault D’ Allonnes, M.: El poder de los comienzos. Ensayos sobre la autoridad ..., p.182.

${ }^{461}$ WeBER, M.: Economía y Sociedad ..., p. 197. 
la desaparición del líder; ante esta situación las respuestas a la sucesión serían: la elección por búsquedas de señales; por revelación; por la designación del antecesor; elección por el cuadro administrativo; por herencia de sangre. La respuesta definirá la naturaleza de las relaciones sociales que emergiesen.

La situación precaria de los reyes visigodos podría explicarse a través de esta conceptualización de la autoridad. La figura del rey es equiparable a la vulnerable figura del líder carismático objetivado. Asimismo, aventuramos que la dominación carismática de los reyes visigodos no evolucionó en una dominación tradicional o racional, si pensamos en términos weberianos.

En el tipo ideal de dominación carismática la valoración del líder por sus seguidores es lo que la define, es la relación líder-adeptos la legitimadora del carisma. Al ser la relación la que valida la dominación se produce una ambivalente lectura de la figura del líder carismático. Por momentos, éste aglutina en torno a sí a un grupo de fanáticos ${ }^{462}$, de obediencia ciega; por otros, el poder radica en el reconocimiento de los dominados hacia su líder. Se construye una relación de naturaleza dialéctica.

El desarrollo del problema sobre la dominación y el carisma permite plantear que en esta sociedad — donde la hegemonía regia establecida se enfrentó de forma constante a alternativas de poder y la institucionalización política no cristalizó- las relaciones políticas se construyeron por medio de la negociación del estatus: el rey competía y estaba obligado a triunfar por sobre sus enemigos, pero sobre todo debería demostrar su capacidad para gobernar. La aristocracia estaba posibilitada de impugnar a la dominación y autoridad regia regia, fenómeno que sucedía con frecuencia. Por otro lado, el carisma se convirtió en el medio para que el rey se encumbrase como una genuina autoridad.

A partir de estas premisas y con estos conceptos como norte, analizaremos la evidencia empírica y los mecanismos de la política de los visigodos.

${ }^{462}$ Ibidem, pp. 193-197. 


\section{1}

\section{Primera aproximación a las relaciones intra-aristocráticas a través de sus conflictos. Estudios de casos}

En algunas ocasiones, la documentación disponible permite estudiar los conflictos intra-aristocráticos en profundidad. En esta oportunidad trataremos aquellos que afectaron a Recaredo y Wamba. Elegimos un reinado de fines del siglo VI y principios del VII y otro del último cuarto del siglo VII para resaltar que los rasgos centrales de la dinámica política visigoda fueron de larga duración. A medida que relatamos los conflictos, indicaremos los elementos de las relaciones entre aristócratas para luego analizarlos de forma particular.

\section{Recaredo}

Como hemos visto anteriormente, Leovigildo ${ }^{463}$ 1levó a cabo una serie de campañas bélicas contra varios polos de dominio y fortaleció el gobierno central ${ }^{464}$. Recaredo como consors regni desde $573^{465}$ fue un protagonista importante en el escenario político orquestado por su padre. Luchó contra varios enemigos de los godos ganándose el respeto de la aristocracia $^{466}$; también combatió, en alianza con Leovigildo, a su hermano Hermenegildo ${ }^{467}$.

\footnotetext{
${ }^{463}$ Las acciones de gobierno de Leovigildo están muy bien documentadas. Su reinado es estudiado a fondo por los especialistas. Para profundizar ver: VALVERDE CASTRO, Ma.R.: "Leovigildo: Persecución religiosa y defensa de la unidad del reino", Iberia: Revista de la Antigüedad, 2, 1999, pp. 123-132. KocH, M.: "La imperialización del Reino visigodo bajo Leovigildo: ¿es la "imitatioimperii" de Leovigildo la manifestación de un momento de cambio en la pretensión de poder y la ideología visigoda?", Pyrenae: revista de prehistòria i antiguitat de la Mediterrània Occidental, Vol. 39, 2, 2008, pp. 101-117. SÁNCHEZ-GuISANDE, J.N.: "El trasfondo políticoreligioso del enfrentamiento entre el rey Leovigildo y el obispo Masona de Mérida", Compostellanum: revista de la Archidiócesis de Santiago de Compostela, Vol. 51, 1-2, 2006, pp.27-60. GarCía Moreno, L.A: Leovigildo: unidad y diversidad de un reinado, Real Academia de Historia, Madrid, 2008.

${ }^{464}$ Leovigildo es considerado por algunos investigadores como el artífice del reino visigodo. Ver por ejemplo: Wolfram, H.: The Roman Empire and Its Germanic Peoples, Berkeley: University of California Press, 1997, p. 265.

${ }^{465}$ IOHAN BICL. Chr., p, 65.

${ }^{466}$ CASTEllanos, S.: Los godos y la cruz. Recaredo y la unidad de Spania ... p. 104 y ss. El capital simbólico que significó el éxito bélico en la construcción del poder y la autoridad es objeto de estudio del capítulo 7 .

${ }^{467}$ El hijo rebelde comenzó su ofensiva en el año 578 apoyado por la reina Gosvinta, ocupó Sevilla y pronto alcanzó Mérida. Según Gregorio de Tours, Ingundis, esposa de Hermengildo fue quien instó a Hermenegildo a que se convierta al catolicismo. A raíz de su conversión y su intención de gobernar desde Sevilla, se desató una
} 
No obstante, el éxito del periodo leovigildiano, Recaredo heredó un reino con fronteras aún no consolidadas, una maquinaria estatal centralizada casi inexistente, fuertes aristocracias locales cuyos intereses no siempre coincidían con los de Toledo ${ }^{468}$ y dos credos cristianos.

En el año 586, a la muerte de Leovigildo, Recaredo asumió el trono en solitario. Sus primeras acciones de gobierno estuvieron destinadas a consolidar su posición como rey. Selló un pacto político con la reina viuda Gosvinta al adoptarla como madre ${ }^{469}$, con el fin de relacionarse con un sector aristocrático muy fuerte y establecer relaciones pacíficas con el reino de los francos. También, envió a la tierra de los galos una embajada con regalos para lograr ese objetivo ${ }^{470}$. A pesar de los esfuerzos y los planes matrimoniales trazados ${ }^{471}$, estas negociaciones fracasaron. En el año 589, Gontrán de Burgundia no acordó con el rey visigodo y envío tropas a la Narbonense que fueron aplastadas por el dux Claudio (la intervención franca tiene una íntima conexión con la revuelta más desarrollada posteriormente). Mientras Recaredo se ocupaba de resolver los problemas con los francos, sus acciones políticas, en especial su conversión al catolicismo, desencadenaron consecuencias en el interior del reino que necesitaron de su atención. Los primeros años de reinado de Recaredo fueron problemáticos. El mismo rey reconoció en una carta enviada a Gregorio Magno que durante tres años tuvo que ocuparse del reino ${ }^{472}$, esta referencia inespecífica solo puede estar

guerra que culminó con el destierro de Hermengildo a Valencia y su posterior asesinato en el año 585. IOHAN BICL. Chr., p. 71. Greg. TuR. Hist. Franc., pp. 245, 287, 310, 314. ISID. Hist. Goth., p. 252. Para más detalles de esta conspiración ver: CASTELLANOS, S.: Los godos y la cruz. Recaredo y la unidad de Spania... p. 109 y ss, GarCía Moreno, L.A.: Historia de España Visigoda ..., p. 114 y ss.

${ }^{468}$ Sobre los poderes locales ver: CASTELLANOS, S. y MARTín VISO, I.: "The local articulation of central power in thenorth of theIberianPeninsula (500-1000)", Early Medieval Europe 13.1.

${ }^{469} \mathrm{La}$ figura de Gosvinta es muy estudiada por los historiadores por su relevante papel político. Ver en especial: ORLANDIS, J.: "Una reina visigoda: Goswintha", Semblanzas visigoda, Madrid: Rialp, 1992. GodOY, Y.: Gosvinta. La Regina deiVisigoti (525 ca. -589), Milano: Jaca Book, 2004. Isla FrEZ, A.:” Reinas de los godos”, Hispania, vol. LXIV, 2004. VALVERDE CASTRO, Ma.R.: "Mujeres < viriles< en la Hispania visigoda. Los casos de Gosvinta y Benedicta”, Studia Histórica, Historia Medieval, Salamanca, n²6, 2008. El rol de la mujer en la política visigoda es un tema que desarrollaremos en otro lugar.

${ }^{470}$ Greg. TUR. Hist. Franc., p. 415.

${ }^{471}$ Castellanos, S.: Los godos y la cruz. Recaredo y la unidad de Spania... p. 269. ISLA Frez, A.: "Las relaciones entre el reino visigodo y los reyes merovingios a finales del siglo VI", En la España medieval, 13, 1990, pp. 11-32.

${ }^{472}$ Concilios, Incipit epistola Recharedi regis gotorum ad beatum Gregorium romensem episcopum directa. "Unde nos multasque regni curas gerimus diversis occasionibus occupati, tres potuerunt anni voluntatem animi nostri minime satisfacere". p. 144. La autenticidad de la carta está en estudio. Algunos autores consideran que su redacción es una respuesta tardía a la carta enviada por Gregorio Magno en el año 599 a Recaredo (GREG. 
haciendo alusión a las rebeliones que se produjeron entre su conversión al catolicismo y la celebración del III Concilio de Toledo, las cuales a continuación repasaremos.

En el año 587 Recaredo se convirtió al catolicismo. Los especialistas coinciden en señalar que el objetivo regio había sido unificar el reino jurídica, política y territorialmente ${ }^{473}$, y eliminar la última diferencia existente entre los godos y la fuerte aristocracia de origen romano ${ }^{474}$. Asimismo, el rey logró "la inclusión de las células de poder episcopal en la articulación política del reino" ${ }^{475}$. Lejos de significar el ascenso de una teocracia o la subordinación del poder laico al eclesiástico, la conversión del reino al catolicismo hizo posible que la interacción de los dos estamentos de la clase aristocrática aumentase y, como Wood señaló ${ }^{476}$, que la relación que mantuvieron los reyes visigodos y la Iglesia fuera de mutuo beneficio.

Para alcanzar el éxito el plan regio necesitó que laicos y eclesiásticos aceptaran al catolicismo como su religión. Juan de Bíclaro relata que el rey convenció a los poderosos obispos arrianos de renunciar a su credo y abrazar al catolicismo ${ }^{477}$; sin embargo, la situación

MAG. Ep., p. 225.). No obstante, la discusión sobre la datación y la autenticidad de la carta, la observación contenida en ella es un indicio sumamente importante para nuestra investigación. Si el mismo rey o un contemporáneo suyo consideró oportuno incluir la referencia a las rebeliones se puede suponer que fue porque constituyeron una conmoción política de gran alcance. Sobre la autenticidad de la carta ver: CODOÑER, C. (coord.): La Hispania visigótica y mozárabe: dos épocas en su literatura ..., p. 87 y s. NAVARRO CORDERO, C.: "El giro Recarediano y sus implicaciones políticas: el catolicismo como signo de identidad del Reino Visigodo de Toledo", Ilu. Revista de ciencias de las religiones, 5, 2000, pp. 97-118.

${ }^{473}$ Díaz Martínez ha señalado: “(...) Reccared realized his father’s policy of seeking a territorial rather than an ethnic monarchy. For this reason he advocated his own conversion and that of his people to Catholicism". DíAz MARTíneZ, P.C.: "Visigothic political institutions", en HEATHER, P. (ed.): The Visigoths from the Migration Period to the Seventh Century. An Ethnographic Perspective, Woodbridge: The Boydell Press, 1999, p. 337.

Ver la bibliografía citada por VALVERDE CASTRO, Ma. R.: Ideología, simbolismo y ejercicio del poder real en la monarquía visigoda ..., p.17.

${ }^{474}$ LORING, Ma. I., PÉREZ, S. Y FUENTES, P.: La Hispania tardorromana y visigoda..., p 169. DÍAZ MARTínEZ, P.C.: Hispaniatardoantigua y visigoda ..., p.378. VALVERDE CASTRO, Ma. R.: Ideología, simbolismo y ejercicio del poder real en la monarquía visigoda ..., p.170 y ss. Collins, R.: La España Visigoda 409-711 ... p 64;

${ }^{475}$ CASTEllanos, S.: Los godos y la cruz. Recaredo y la unidad de Spania... p. 214.

${ }^{476}$ WoOD, J.: The Politics of Identity in Visigothic Spain: religion and power in the histories of Isidor of Seville, p. 50. KoON, S. Y WoOD, J.: "Unity from disunity: law, rhetoric and power in the Visigothic kingdom", European Review of History: Revue européenned'histoire, vol. 16, 6, 2009.

${ }^{477}$ IOHAN Bicl. Chr., p. 78: "Recaredus primo regni sui ano mense $X$ catholicus deo iunante efficitur et sacerdotes secte Arrianae sapienti colloquio aggressus ratione pocius quam imperio conuerti ad catholicam fidem facit, gentemque omnium Gothorum et Sueuorum ad unitatem et pacem reuocat Christiane ecclesie, secte Arriane gratia diuina in dogmate ueniunt Christiano". 
no fue tan sencilla ${ }^{478}$. La conversión personal recarediana tuvo un gran impacto político que se materializó en varias revueltas. La primera respuesta se concretó en la conjura organizada en la ciudad de Mérida contra el rey, cuyo instigador principal había sido el obispo arriano Sunna y su víctima su par católico, Masona.

Castellanos sostuvo que Masona fue un apoyo fundamental en la revuelta de Hermenegildo, sin embargo, con la conversión de Recaredo el otrora enemigo se transformó en un gran aliado. No ha sido raro el cambio en las alianzas políticas ni las actitudes acomodaticias. Recaredo necesitaba el sustentáculo de los grandes del reino y Masona tenía la capacidad de otorgárselo (la misma estrategia utilizó con la reina viuda Gosvinta). Juan de Bíclaro narra que el nuevo rey católico restituyó los bienes que su padre había confiscado, también fundó iglesias y monasterios y los enriqueció ${ }^{479}$. Isidoro de Sevilla reproduce la misma información confirmando la devolución de los bienes a las iglesias católicas ${ }^{480}$. La nueva correlación de fuerzas políticas y los beneficios que el rey otorgó a los católicos despertaron las reticencias de los arrianos. El biclarense y el autor de las VSPE brindan los datos para estudiar a fondo esta primera revuelta ${ }^{481}$.

Meses después de la conversión de Recaredo, Sunna, el obispo emeritense arriano, y varios condes ${ }^{482}$ de la ciudad idearon un plan para aniquilar a Masona. Sunna le envió un mensaje a Masona para que acudiese a su casa, pero sospechando de la situación, el católico se negó y lo invitó al atrio de su iglesia. Entonces, Sunna ordenó a los condes que una vez en el interior de la iglesia Witerico debería atravesar con la espada a su enemigo.

Masona convocó al dux Claudio, un aristócrata católico que acudió con una gran comitiva y se reunió junto a los demás asistentes, según la costumbre. Witerico, situado detrás del obispo católico, intentó varias veces desenvainar su espada, mas le resultó imposible (por supuesto, el autor de la hagiografía sostiene que fue la voluntad de Dios la que impidió el ataque). Los conjurados lanzaban miradas acusatorias a Witerico y, estupefactos porque el verdugo asignado no cumplía con su plan, se marcharon.

\footnotetext{
${ }^{478}$ CASTEllanos, S.: Los godos y la cruz. Recaredo y la unidad de Spania... p.152.

${ }^{479}$ IOHAN BICL. Chr., p. 78: "Reccaredus rex aliena a precessoribus direpa et fisco sociata placabiliter restituit, ecclesiarum et monasteriorum conditor et ditator efficitur "

${ }^{480}$ ISID. Hist. Goth., pp. 264 y ss.

${ }^{481}$ VSPE, p. 81 y ss..". IOHAN BICL. Chr., p. 79 y ss.

482 De los condes nombrados conocemos solo a dos: el biclarense menciona a Segga (IOHAN BICL. Chr., p. 79), y el autor de las VSPE solo a Witerico. VSPE, p. 81.
} 
Witerico permaneció en el atrio y en un tono arrepentido le contó a Masona todo el plan y cómo la intervención divina impidió que su espada lo asesinara. Pero no solamente confesó el crimen que estuvo a punto de cometer, también reveló el plan alternativo existente que se emplearía en caso de fracasar el primer intento. El arrepentido divulgó que en la procesión de la misa de Pascuas los hombres de Sunna estarían esperando en las puertas de la ciudad con carros llenos de espadas y palos y, como Masona y sus seguidores se encontrarían desprovistos de armas, los atacarían dando muerte a todos los concurrentes de la procesión, sin distinguir entre hombres y mujeres o niños y viejos. Masona informó de esto a Claudio, quien emprendió una investigación y comprobó la verdad del relato de Witerico. A la luz de los hechos, decidieron mantener el secreto para evitar las fugas de los implicados.

En Pascuas los arrianos habían dispuesto todos los elementos necesarios para la emboscada, pero Claudio frustró sus planes cuando por sorpresa se hizo presente y atacó a aquellos que quisieron defenderse con las espadas, mientras que a otros solo los hizo prisioneros. Luego de desbaratar la operación, fue a casa de Sunna que quedó bajo custodia junto a sus otros cómplices. La excepción la hicieron con Witerico, quien obtuvo su libertad por revelar los planes.

Las noticias llegaron a Recaredo a través de Claudio quien le pidió que promulgue una sentencia. El rey, haciendo caso del consejo, dictó que todos los conjurados fueran privados de sus patrimonios y honores, y atados a cadenas fueran exiliados. Exhortó a Sunna a convertirse al catolicismo: en caso de aceptar (luego de la penitencia y de probar su comportamiento) sería nombrado obispo en otra ciudad. Sunna rechazó al catolicismo, por lo tanto, fue echado de las fronteras de Hispania, y le dijeron que fuera por mar a donde quisiera, lo que finalmente hizo desembarcando en la provincia de Mauritania. Tras el exilio de Sunna, Masona consiguió la restitución de las propiedades de la iglesia que había perdido a manos de Leovigildo; sumado a esto, Recaredo le entregó todo el patrimonio que dejó atrás Sunna.

Otro de los conjurados, de nombre Vagrila, escapó del exilio refugiándose en la basílica de Santa Eulalia. Al enterarse de esto, Recaredo ordenó que Vagrila, su esposa, sus hijos y su patrimonio fueran consagrados a perpetuidad como servidores de la iglesia de Santa Eulalia, debiendo prestar servicios como los siervos más ínfimos. Además, Vagrila marcharía delante del caballo del diácono Redempto como lo acostumbraban los siervos. Masona, en 
muestra de su misericordia, liberó al condenado, a su familia y a sus bienes con la condición de que mostrasen una fe intachable todos los días de sus vidas. La crónica biclarense nos informa del destino de otro conde implicado: Segga. Este fue desterrado, pero antes sufrió la ablación de sus dos manos ${ }^{483}$.

El fracaso del primer intento de eliminar a Recaredo no desanimó a otros sectores aristocráticos de planear y ejecutar otros ataques. En las primeras semanas del año 589 Gosvinta junto al obispo Uldila de Toledo fueron los líderes de una revuelta en la capital del reino; la misma había sido sofocada rápidamente por Recaredo evitando que sus acciones tomasen mayores dimensiones. Uldila fue condenado al destierro y sabemos que Gosvinta falleció, pero no existe en las fuentes el dato sobre la causa ${ }^{484}$. Mientras que en Toledo Recaredo hacía frente a este peligro, casi en simultáneo en Narbona se produjo una gran rebelión. Ataloco, obispo metropolitano de la sede arriana, junto a los comites Granista y Wildigerno $^{485}$ encabezaron una rebelión abierta contra la conversión al catolicismo que pretendía Recaredo y contra el mismo rey. Según Gregorio de Tours, Ataloco murió en su cama y con su muerte la revuelta perdió fuerza. Sin embargo, como apuntó Castellanos, la tensa situación entre el rey y los poderes locales de Narbona no tuvo una rápida solución ${ }^{486}$. En noviembre del 589, a solo unos meses del cambio de credo oficial y de la conjura, se celebró el Concilio de Narbona por orden regia. Los cánones promulgados reglaban las conductas católicas, mas también, y teniendo en cuenta el contexto político sensible, apuntaban a disuadir posibles levantamientos contra el rey. El tercer canon instó a cualquier clérigo, subdiácono, diácono o presbítero a no sentarse, pararse o entablar conversaciones en las plazas públicas; el verdadero sentido de esta prohibición se revela con la lectura del quinto canon: allí se especificó, siguiendo los mandatos del Concilio de Nicea, que los clérigos no deberían participar en conjuraciones ni conspiraciones patrocinadas por los laicos ${ }^{487}$. La aristocracia laica y eclesiástica participó de todas formas en las revueltas contra los reyes, a pesar de las múltiples prohibiciones y sanciones conciliares.

\footnotetext{
${ }^{483}$ IOHAN BICL. Chr., p. 79.

${ }^{484}$ Idem.

485 VSPE, p. 92 y 93.

${ }^{486}$ CAStellanos, S.: Los godos y la cruz. Recaredo y la unidad de Spania... pp. 160 y 161.

${ }^{487}$ Concilios, Narbona, año 589, c. 3 y 5, p. 147.
} 
Una última revuelta tuvo que enfrentar Recaredo. En el 590 Argimundo, dux y miembro del entorno regio (era un cubiculario ${ }^{488}$ ), lideró un levantamiento con el fin de tomar el reino y quitarle la vida al rey ${ }^{489}$. Descubiertos los planes, los socios de Argimundo fueron torturados y ejecutados. El cabecilla sufrió un castigo ejemplar: interrogado a latigazos, vergonzosamente decalvado, se le amputó la mano derecha y fue paseado en el lomo de un asno por Toledo ${ }^{490}$. No sabemos su destino final, si fue ejecutado como sus socios o si conservó la vida como Segga.

La conversión de Recaredo significó un duro golpe para el poder político de los arrianos que no abjuraron de su fe. En un pasaje de sus Diálogos Gregorio Magno indicó que Recaredo excluyó a éstos de los asuntos del reino ${ }^{491}$, lo cual podemos entender que los privó de participar del gobierno central y de las provincias, a la vez que les negaba la administración de los bienes del fisco y de origen eclesiásticos. De seguro, esta noticia la debemos articular con el canon noveno del Concilio de Toledo III ${ }^{492}$, por el cual se dispuso que las iglesias arrianas y sus bienes quedasen bajo el control del obispo católico. Castellanos señaló que no solo hubo un traspaso de bienes, sino que también se quiso borrar toda huella del arrianismo ${ }^{493}$. Así se comprenden las medidas adoptadas en el Concilio de Zaragoza, por las cuales se obligaba a comprobar mediante la prueba del fuego la autenticidad de las reliquias provenientes de las iglesias antes arrianas (canon segundo) y a consagrar por un obispo católico las iglesias inauguradas por uno arriano (canon tercero) ${ }^{494}$. Es evidente que, después de la adopción del catolicismo como fe oficial, los católicos no podrían permitir por cuestiones de fe, y por cuestiones de competencia por el dominio político, que los bienes y las reliquias de las iglesias arrianas continuaran bajo su potestad.

\footnotetext{
${ }^{488}$ ISLA FREZ, A.: "El officium palatinum visigodo. Entorno regio y poder aristocrático", Hispania: Revista española de historia, 212, 2002, p. 838.

${ }^{489}$ IOHAN BICL. Chr., p. 79.

${ }^{490}$ Idem.

${ }^{491}$ GREG. MAG. Diag. Libro III, cap. XXXI, pp. 292.“(...) ut nullum suo regno militare permitteret, qui regno Dei hostis existere per hereticam perfidiam non timeret".

${ }^{492}$ Concilios, Toledo III, año 589, c. 9. "Ut ecclesiae Arrianorum ad catholicum episcopum in cuius dioecesi sunt pertineant", p. 127.

${ }^{493}$ CaStellanos, S.: Los godos y la cruz. Recaredo y la unidad de Spania ... p. 253 y s. ORLANDIS, J.: Historia del Reino visigodo español..., p. 301

${ }^{494}$ Concilios, Zaragoza, año 592, p.154.
} 
La conversión de Recaredo en términos políticos - y económicos - significó una reacomodación del escenario político y de los recursos. Tanto laicos como eclesiásticos sufrieron la pérdida del poder, de sus bienes materiales y de su posición de privilegio. Por estos motivos encontramos a ambos estamentos aristocráticos siendo partícipes de las murmuraciones, las complicidades y coordinando los planes rebeldes contra Recaredo. Sin embargo, a pesar de las revueltas iniciales vistas, el rey pidió la conversión de todo el reino, y muchos obispos y laicos arrianos en poco tiempo aceptaron la fe nicena.

Tal vez la rápida conversión —en sentido práctico y no dogmático - fue una derivación de las reuniones que tuvo Recaredo con los arrianos antes de la promulgación formal de la conversión en el Concilio de Toledo III, donde se negoció y acordó que al clero arriano convertido se le aseguraría su posición de privilegio en la estructura de la iglesia católica ${ }^{495}$; el perdón y la oferta de conversión a Sunna tras su rebeldía ha sido una muestra de las aspiraciones políticas regias con relación a incluir en su red a los poderosos locales, sean católicos de origen o conversos como él mismo. Por su parte, para los miembros católicos la conversión de Recaredo fue una oportunidad para acrecentar sus beneficios bajo el amparo del dominio político laico, obteniendo una situación de privilegio y siendo uno de los motivos que los llevó a aceptar la autoridad del rey visigodo abandonando la protección de los emperadores ${ }^{496}$.

La rápida acomodación de los laicos y eclesiásticos otrora arrianos en las estructuras políticas católicas es mejor comprendida si reconocemos que las conversiones religiosas son acciones políticas concretas que responden a la lógica reciprocitaria de las relaciones sociopolíticas del periodo: las lealtades (políticas y/o religiosas) se brindaban a aquellos que garantizasen beneficios materiales y el estatus social. El episodio relatado por Isidoro de Sevilla sobre cómo Leovigildo convenció a muchos de convertirse al arrianismo ofreciéndoles oro y bienes ${ }^{497}$ debe ser comprendido bajo la lógica desarrollada.

\footnotetext{
${ }^{495}$ VALVERDE CASTRO, Ma. R..: Ideología, simbolismo y ejercicio del poder real en la monarquía visigoda..., p.169. Collins, R.: La España Visigoda 409-711 .... p. 64.

${ }^{496}$ VALVERDE CASTRO, Ma. R.: Ideología, simbolismo y ejercicio del poder real en la monarquía visigoda ..., p.169 y ss. Además, la iglesia hispana se había distanciado de la iglesia imperial por problemas doctrinales y por aquellos causados por la presencia de los bizantinos en la Península Ibérica. LORING, Ma. I., PÉREZ, S. Y FuENTES, P.: La Hispania tardorromana y visigoda..., p 169. Las cuestiones del acrecentamiento y administración de los bienes de la Iglesia católica no son tratadas en este capítulo.

${ }^{497}$ ISID. Hist. Goth., p. 256.
} 


\section{Wamba}

Desde el principio del reinado de Recesvinto, Wamba cultivó un vínculo estrecho con este rey, dato que obtenemos de la lectura del Concilio de Toledo X en cuyas actas fue reconocido como vir illustris y representante regio ante la asamblea; también fue el encargado de presentar el testamento de san Martín de Braga para ser analizado por los allí reunidos ${ }^{498}$. En septiembre del 672, en la villa de Gérticos, ubicada en territorio Salmanticense, moría Recesvinto; en su lecho de muerte fue rodeado por sus más allegados colaboradores: los hombres ilustres del palacio y entre ellos su sucesor. En esa misma villa, Wamba fue consagrado rey por elección de sus pares siguiendo las disposiciones conciliares, y luego confirmado en Toledo ${ }^{499}$.

Pasado poco tiempo de su entronización, Wamba tuvo que enfrentar una rebelión aristocrática en la Galia gótica, comandada por Ilderico, comes de Nimes. En ese momento se encontraba combatiendo personalmente a los vascones y por ello envió a un $d u x$ de su círculo íntimo, Paulo, a sofocar la revuelta. Al llegar a Narbona, el duque de la Tarraconense, Ranosindo, persuadió a aquel de aclamar el trono para sí mismo ya que contaba con el apoyo de gran parte de la aristocracia y de los funcionarios locales del noreste. De esta manera, Paulo se convirtió en el principal instigador del tumulto traicionando su vínculo con el rey ${ }^{500}$. Finalmente, en una seguidilla de campañas bélicas, Wamba triunfó sobre los rebeldes que fueron enjuiciados. Un documento conocido como Iudicium in tyrannorum perfidia promulgatum $^{501}$ brinda detalles del proceso y del castigo.

Tres días después del triunfo regio, Wamba se reunió con “(...) senioribus cunctis palatii, gardingis omnibus omnique palatino officio, seu etiam adstante exercitu uniuerso (.... ",502 para celebrar el juicio contra Paulo y los otros jefes de la rebelión. El autor del relato judicial afirma de forma elocuente que sus delitos consistieron en violar la promesa de fidelidad y ser los traidores que prepararon la destrucción del pueblo llamando para ello a

\footnotetext{
498 Concilios, Toledo X, año 656, c. “Item aliud decretum eorundem prafatorum pontificum editum”, p. 322.

499 IUL. TOL. $H W$, p. 219 y 220.

${ }^{500}$ IUL. TOL. $H W$, p. 222 y ss.

${ }^{501}$ IUL. TOL. $H W$, pp. 250-255.

502 IUL. TOL. $H W$, p. 254.
} 
extranjeros $^{503}$. Al inicio del juicio, según el relato, Wamba se dirigió a Paulo preguntándole si lo había ofendido o en si en alguna ocasión alimentó la maldad que estimuló a que emprendiera la tiranía ${ }^{504}$ e intentara tomar "regni apicem"505 (estos términos podrían interpretarse como la más alta dignidad del reino o corona, teniendo en cuenta que un apex es descripto por Isidoro de Sevilla como un birrete ${ }^{506} \mathrm{y}$, además, Paulo protagonizó una ceremonia de coronación). Paulo contestó que nunca se sintió lastimado por su gloria ni recibió mal alguno porque Wamba siempre había dado la orden de compartir las mercedes que, de acuerdo con su entender, él no merecía (sed tantum boni in me impertire iussisti, quod percipere omnino non merui $)^{507}$. El rey realizó la misma pregunta a los soccis de Paulo, que contestaron de igual modo.

No podemos afirmar con certeza que el diálogo entre Wamba y Paulo se hubiese producido en la forma en que se plasmó en el relato judicial; sin embargo, es un testimonio sumamente valedero y clave para comprender la dinámica de las relaciones intraaristocráticas y los motivos de la sublevación comandada por Paulo. En primer lugar, porque el autor seleccionó éste único intercambio de palabras de las muchas preguntas y respuestas que suponemos fueron formuladas y obtenidas respectivamente (con altas probabilidades bajo tortura u otros métodos que fueron omitidas voluntariamente en el escrito); no obstante, tanto su estructura gramatical como el léxico utilizado, y el estilo, debieron tener un alto grado de verosimilitud para el público aristocrático al que estaba destinado el conjunto de obras que relata la Historia Wambae — casi contemporánea a los hechos que narra—. Por lo

\footnotetext{
${ }^{503}$ IUL. TOL. HW, p. 250: "Perfidorum denotata transgressio ideo debetur acrius percuti, quo inlicitis uidetur ausibus perpetrati. Habeant ego confusionis propriae signum, quibus contingit fidei uiolare promissum. Reportent nomen proditionis in posteros, quos indulgentia principalis fecit esse ingratos. Renotentur inter cuneos perfidorum, qui genti suae parauentur excidium, ut reportent in progenies saeculorum titulos infamiae suae, qui eversores facti sunt patriae; quibus ex clementia princeps dederit vivere, effossionem luminum non evadant, qui patriae gloriam minuentes proditionis notam incurrerant. Nam ecce! prodidit sese in apertum campum infausta perfidia, quae nefandorum societatem cruentis sibimet amplexibus socians commouit ad scandalum ciues, ad suorum perniciem plebes, ad eversionem patriae gentes, ad interitum principis non solum proprias, sed externarum plebium nationes".

504 Sobre la figura de Paulo como tirano en el sentido clásico ver: GuIANCE, A.: "Rex perditionis. La caracterización de la tiranía en la España visigoda”, Cuadernos de Historia de España, 2000-2001, pp. 77, 2940.

${ }^{505}$ IUL. TOL. $H W$, p. 254: "si aut te in aliquo laesi aut occasione qualibet malitiae tibi nutriui, per quod excitatus hanc tyarnnidem sumeres vel huius regni apicem suscipere attemptares".

${ }^{506}$ ISID. Etymologiae, p. 1312.

${ }^{507}$ IUL. TOL. $H W$, p. 254.
} 
tanto, la preferencia de palabras que hace el autor se vuelve relevante en sí misma. Y para nosotros este diálogo es iluminador.

Este escueto intercambio desvela mejor la naturaleza de los vínculos políticos. Observamos que Wamba le preguntó a su antiguo hombre de confianza si algún acto suyo había derivado en la ruptura de la fidelidad por parte de Paulo, es decir, si como jefe lo había defraudado o no había sido justo o generoso. Paulo reconoció (en forma discursiva como mínimo) que Wamba siempre había compartido los bienes ganados con él, tal como se esperaba que un jefe hiciese. Aquí encontramos un componente esencial de la relación intraaristocrástica: el jefe debía entregar mercedes y esperar fidelidad.

Finalmente, por vulnerar el juramento regio de fidelidad los implicados en la revuelta sufrieron severas penas: pérdida de la capacidad procesal, confiscaciones de bienes y reducción a la servidumbre regia; además, se los humilló en una procesión en Toledo donde lucían “(...) decaluatis capitibus, abrasis barbis pedibusque nudatis, subsqualentibus ueste uel habitu induti, camelorum uehiculis imponuntur" ${ }^{\circ 08}$. La rebelión de Paulo fue una gran amenaza para el reinado de Wamba, que éste enfrentó con éxito. Sin embargo, el castigo a los implicados repercutió varios años después.

Al siguiente año de la rebelión, Wamba tomó medidas entendidas como una forma de contener y castigar a aquellos sectores que tuvieron participación directa y a aquellos que por omisión voluntaria no intervinieron a favor del rey.

En principio, redactó una ley de jurisdicción militar ${ }^{509}$ donde prescribió que todo eclesiástico de gran dignidad, o “dux, comes, thiufadus, vicarius, gardingus”, o cualquier hombre libre (nobiles, mediocriores, viliores) que se encontrase a una distancia de cien millas de un ataque desde el exterior o de una revuelta doméstica acudiese "cum omni virtute sua ${ }^{510}$. Aquellos que no cumplieran $-\mathrm{y}$ si los territorios arremetidos resultaban seriamente perjudicados - perderían el derecho a testificar, serían relegados a la servidumbre o confinados al destierro, sus bienes se incautarían y se destinarían a compensar los daños. Al

508 Ibidem, p. 244. Sobre los castigos ver: MCCORMICK, M.: Eternal victory. Triumphal rulership in Late Antiquity, Byzantium and the Early Medieval West, Cambridge: Past and Present Publications, Cambridge University Press, 1986, capítulo 8.

${ }^{509}$ En el próximo capítulo se estudia esta ley en profundidad.

${ }^{510} L V, 9,2,8$. p. 370. 
parecer, por testimonios posteriores, los castigos previstos por esta norma fueron aplicados y la dureza de la ley no fue solo retórica.

La aristocracia laica no había sido la única que soportó los embates de Wamba; los eclesiásticos también fueron objeto de disposiciones que tenían como propósito segar su poder $^{511}$. En el Concilio de Toledo XI del año 675 una serie de disposiciones estuvieron destinadas a limitar las acciones episcopales que a los criterios de los reunidos sobrepasaban los derechos eclesiásticos. En relación con el patrimonio, Wamba procuró reprender la apropiación de los bienes de particulares o pertenecientes al fisco indebidamente por parte de la Iglesia (canon 5) ${ }^{512}$. También promulgó la ley 4, 5, 7 que prohibía el matrimonio entre libertos de la iglesia y hombres libres ${ }^{513}$, para así sustraer a los descendientes de estas uniones de la dependencia de la Iglesia. Una última disposición permite intuir el propósito de Wamba: la creación de nuevas diócesis, entre ellas la sede de la iglesia castrense de los santos Pedro y Pablo situada en las afueras de la urbe regia ${ }^{514}$. Finalmente, el Concilio rememoró en su canon sexto la prohibición que recaía en los miembros de la iglesia de juzgar los delitos que tenían como castigo el derramamiento de sangre. Estas normas estuvieron destinadas a contener el dominio episcopal y reducir las posibilidades de alianzas entre los sectores laicos y eclesiásticos. Los cánones del undécimo concilio toledano fueron escritos, en su mayoría, con un tono de reprensión: a los obispos se los acusó de ambiciosos, abusivos, engañadores, imprudentes, simoníacos, mercenarios y hasta como homicidas; no debe extrañarnos que detrás de tan duras palabras y sanciones estuviese la intención de Wamba de acotar un poder político que, sin acatar las leyes de su estamento, participaba tanto de forma abierta como conspirativamente contra el centro.

Las acciones descritas implicaron un fuerte golpe a los magnates, tanto que en el año 681 en la celebración del decimosegundo Concilio de Toledo Ervigio exhortó a restaurar la honra de aquellos que no acudieron a la movilización del ejército de los años previos, pues de mantener las penas se padecería la pérdida perpetua de la casi mitad del pueblo ${ }^{515}$. La

\footnotetext{
${ }^{511}$ LORING, Ma. I., PÉREZ, S. Y FUENTES, P.: La Hispania tardorromana y visigoda ..., p. 192

512 Concilios, Toledo XI, año 675, c. 5, p. 358 y ss.

${ }^{513} L V$, pp. 205 y 206.

514 Se conoce la existencia de un nuevo episcopado más: el ubicado en el monasterio de San Pimenio en Aquis. GArcía Moreno, L.A.: Historia de la España visigoda, p.174.

515 “(...) decurrit dimidiam fere partem populi ignobilitati perpetuae subiugavit (...)”, Concilios, Toledo XII, año 681, exhortación del rey Ervigio, p. 383.
} 
Iglesia también quiso revertir las consecuencias no deseadas del reinado de Wamba. La creación de nuevos obispados había sido calificada de injusta, como un abuso insolente y escandaloso $^{516}$, por lo tanto, se pidió la abolición de las nuevas sedes que con ligereza y por la obstinación del rey se habían creado ${ }^{517}$. Estas duras expresiones difundidas luego del reinado de Wamba señalan de la incomodidad que este rey provocó tanto a la Iglesia como a los laicos. Como veremos, la aristocracia, al sentir el ataque a sus bases materiales y de poder político, reaccionó vivamente ante un rey que no cumplía con lo esperado: se planeó un destronamiento prolijo y sin derramamiento de sangre que terminó con el reinado de Wamba.

Existen suficientes datos para reconstruir los sucesos conspirativos organizados contra Wamba ${ }^{518}$. El Concilio de Toledo XII del año 681 consideró urgente tratar y establecer las circunstancias en que Ervigio asumió el solio godo. Para efectuar esta tarea los obispos inspeccionaron una serie de documentos, por medio de los cuales se constató que Wamba padecía una gravísima enfermedad ${ }^{519} \mathrm{y}$, a causa de su frágil salud, recibió el sacramento de la penitencia, la señal de la tonsura y el hábito religioso. También los eclesiásticos examinaron un escrito en el cual se constató que Ervigio fue elegido por Wamba para sucederle por su propia decisión y el decreto original de Wamba, dirigido al obispo Julián de Toledo donde pedía la unción regia de su sucesor con la mayor presteza. Luego de la observación perspicaz por parte de los obispos reunidos, concluyeron en la legalidad de las escrituras presentadas, pues reconocieron las actas corroboradas por manu seniorum palati,

516 “ideo pro tam insolenti huiusmodi disturpationis licentiam (...)”. Ibidem, Toledo XII, año 681. c. 4. p. 390. ${ }^{517}$ Ibidem, Toledo XII, año 681. c. 4. p. 390.

518 Ibidem, Toledo XII, año 681, p. 380 y ss. Lat. Reg. Vis., p. 468 n. 46 y 47: “accepit quoque paenitentiam praedictus princeps (Wamba) die dominico exeunte, hora noctis prima, quod fuit pridie id. Oct., luna XV, aera DCCXVIII. suscepit autem succedente die, II feria, gloriosus domnus noster Ervigius regni sceptra, quod fuit id. Oct., luna XVI, aera DCCXVIII, dilata unctionis sollemnitate usque in superveniente die dominico, quod fuit XII k. Nov., luna XXII, aera qua supra".

${ }^{519}$ En la crónica elaborado en la era de Alfonso III se afirma que Wamba fue envenenado por obra del propio Ervigio con una poción a base de esparto. Esta noticia puede ser tomada como inverosímil por el silencio de los documentos contemporáneos al hecho y por el tipo de planta que se habría utilizado. Chron. Rot., p. 116. Bronsich cuestiona fuertemente esta noticia, inclinándose a pensar que la caída en la inconsciencia de Wamba se debió a causas naturales. González Salinero considera posible el envenenamiento. BRONISCH, A. P.: "Precisiones sobre algunas informaciones históricas en la <Crónica de Alfonso III>", Edad Media. Revista Histórica, 12, 2011, pp. 38 y ss. Para más detalles sobre este problema ver el artículo citado, allí el autor realiza un análisis exhaustivo sobre el tema. GONZÁlez SALINERO, R.: Introducción a la Hispania visigoda, Madrid: Uned, 2018, p.127. 
así como la firma genuina del príncipe predecesor. Entonces, por la decisión de todos los obispos de común acuerdo secundaron los papeles presentados por el rey Ervigio.

Hasta aquí la existencia de una conspiración para destronar a Wamba sólo es una sospecha. Sin embargo, la lectura del canon que lleva por título De his qui poenitentiam non sentientes accipiunt ${ }^{520}$ nos dirige hacia la certeza. Este canon devela muchos de los problemas que, posiblemente, hayan enfrentado los obispos al aceptar como válido el sacramento de la penitencia otorgado a Wamba en estado inconsciente o de semi-conciencia, y de allí la sospecha de fraude en el otorgamiento del sacramento. Por un lado, dispusieron que si alguno, estando sin sentido - es decir si perdía la facultad natural de hablar y sentir521 , recibiese la penitencia y la señal de la tonsura debería de todas formas ajustarse a las reglas de la disciplina eclesiástica; al mismo tiempo, aquel que de cualquier modo le fuera otorgada la penitencia, y recuperara su lozanía, jamás volviera a ceñir el cíngulo militar. Sin embargo, el mismo canon amonesta con la pena de excomunión durante un año al obispo que dispusiese la penitencia a aquellos que se encontraran sin sentido, pues argumenta que no se autorizara a los obispos a dar este sacramento a la ligera. Se evidencia que suministrar la penitencia a sujetos en estado inconsciente no era una práctica común como tampoco se lo consideraba aceptable, pues otorgarla era sinónimo de excluir al que la recibiese de la vida militar y política, confinándolo a una vida de oración.

Ervigio hizo todo lo que estuvo a su alcance para que le fuera imposible a Wamba recuperar su puesto. Otra medida promulgada por parte del Concilio en esta dirección fue la disolución del vínculo de juramento hacia Wamba. Con la liberación de los vínculos de fidelidad quedaban deshechas las relaciones de poder que Wamba hubiera utilizado para recuperar su puesto; y, además de esto, la resolución conciliar impelía a los fideles regis del destronado, ya libres de toda obligación, a unirse a las filas de Ervigio prestando "obsequendum grato servitii" 522 .

La prueba para confirmar la conspiración y desestimar una sucesión pacífica aunque no tradicional - fue el acto posterior de los magnates reunidos y, sobre todo, de Ervigio. Resulta claro que Wamba actuaba de manera inoportuna para un conjunto de los

\footnotetext{
${ }^{520}$ Concilios, Toledo XII, año 681, c. II, p. 387.

521 “(...) et rursus nimietate aegritudinis ita loquendi et sentiendi perdidisse naturale officium (...)”, Ibidem, Toledo XII, año 681, c. II, p. 388.

${ }^{522}$ Ibidem, Toledo XII, año 681, c. I, p. 387.
} 
poderosos, como advertimos en los dichos conciliares. Wamba condenó a un gran número de habitantes a la pérdida del derecho de testificar por desertar del ejército, entre los cuales se encontraba un gran número de aristócratas, los mismos que, años después, fueron indultados por Ervigio en el Concilio que refrendó su ascenso al trono ${ }^{523}$. A tres años del nuevo reinado, fue convocado un nuevo Concilio ${ }^{524}$, en el cual se presentó a favor de los sediciosos de la Narbonense (incluyendo al $d u x$ Paulo) la siguiente petición: que les restauren los derechos correspondientes por su estatus noble, anularan las restricciones judiciales impuestas (pérdida del derecho de testificar) y restituyeran los bienes confiscados o dados como ayuda, en la medida que fuera posible sin afectar a otros favorecidos por el rey ${ }^{525}$.

Del análisis de los conflictos que perturbaron a Wamba y las acciones posteriores de Ervigio, podemos colegir el funcionamiento de distintas estrategias que emplearon los reyes para mantener el poder. Mientras que Wamba optó por actuar con dureza para un sector amplio de la aristocracia y su indulgencia solo consistió en perdonarles la vida a los traidores (con seguridad Wamba habrá creído que el exilio, la confiscación de los bienes materiales y la anulación del estatus eran castigos suficientes y una forma de muerte política), Ervigio, para obtener el apoyo de los grandes a su gobierno, los complació en su conjunto derogando leyes que los afectaban, disolviendo juramentos y anulando los mandatos de alguno de sus predecesores. La observación de los problemas que tuvo Wamba a lo largo de su reinado y su final abrupto señala otro aspecto de las relaciones aristocráticas: la fidelidad política. Tanto Paulo como Ervigio rompieron el lazo de fidelidad con su jefe, y esta práctica fue más común de lo que se puede suponer. Ambos personajes aristocráticos tuvieron como objetivo ocupar el trono, y en su afán de lograrlo sacrificaron grandes cantidades de bienes materiales y su capital político.

El análisis sobre las revueltas aristocráticas abre la posibilidad de comenzar a entender la lógica de la dinámica política de los reyes. Los vínculos de fidelidad, las reconfiguraciones de las lealtades y la distribución de bienes se configuraban como los elementos fundamentales de las relaciones políticas; la naturaleza reciprocitaria y el carácter

\footnotetext{
${ }^{523}$ Ibidem, Toledo XII, año 681, c. VII, p. 394.

${ }^{524}$ Ibidem, Toledo XIII, año 683, pliego regio, p. 412 y c. I, p. 415.

${ }^{525}$ Ibidem, Toledo XIII, año 683, c. I, p. 416.
} 
inestable fueron la causa de su fragilidad. En el próximo apartado veremos en profundidad cada uno de estos aspectos señalados.

\section{2}

\section{La dinámica de la relación sociopolítica intra-aristocrática. El vínculo de}

\section{fidelidad y la entrega de premios}

La relación entre el rey y la aristocracia fue desigual como resultado de las diferencias estamentales. Sin embargo, el rango superior regio no logró consolidarse, su figura de autoridad tuvo un carácter flexible y transitivo. La dominación política de los reyes fue inestable, por lo tanto, la aristocracia, en su juego, podía desconocer e impugnar la legitimidad del rey si le placía. La precariedad del cargo, junto a su sublimación, implicó que el lugar del máximo jefe del reino fuera siempre disputado, conservado y anhelado por los grupos aristocráticos, aún si eso significaba la destrucción de bienes materiales y posiciones de privilegio en el proceso de obtenerlo ${ }^{526}$.

En el capítulo anterior hemos observado las múltiples disputas por el trono; como resultado de ellas, los reyes enfrentaron sublevaciones, conspiraciones, invasiones externas $\mathrm{y}$ atentados de forma incesante. Es válida la siguiente pregunta: ¿cómo gobernaron en una sociedad que era orgánicamente inestable? Veremos que para sortear con éxito estos peligros reales debieron construir de forma incesante su Herrschaft y las relaciones políticas con los grandes del reino. Una vez que un aristócrata se convertía en rey (a pesar de las desigualdades generadas por el rango) necesitaba una estructura de poder cuyos cimientos estuvieron constituidos por la fidelidad prometida por sus fideles regis. El examen de las relaciones sociopolíticas entre la aristocracia y el rey es clave para la investigación, pues una de las

\footnotetext{
${ }^{526}$ Martín Viso sostiene que: "La afirmación de la hegemonía visigoda en manos de la monarquía asentada en Toledo no significó sin embargo el final de las tensiones y la estabilidad política fue un objetivo más deseado que realizado. (...) No puede hablarse de una oposición estructural entre monarquía y aristocracia: era imposible gobernar sin el apoyo de una aristocracia, a la que pertenecía el propio monarca. Pero tampoco la aristocracia podía conservar sus espacios de poder sin la existencia de una estructura política que la amparase. (...) Por tanto, parece más adecuado hablar de un acusado faccionalismo, donde subsistían distintas redes políticas, sustentadas en el patronazgo y el clientelismo, que luchaban entre sí por dominar la institución monárquica". MARTín VISO, I.: “Hispania en el periodo postromano (siglos V-VIII)”. p. 34.
} 
causas de la fragilidad institucional y la oscilación del dominio político del reino fue la lógica del sistema de las relaciones predominantes ${ }^{527}$.

La cercanía del rey (Königsnähe), la reciprocidad y la dominación carismática son las herramientas hermenéuticas que permiten comprender el fenómeno de la inestabilidad política. Ya hace tiempo que los historiadores emplean estos conceptos para explicar las prácticas sociales temprano medievales, aunque para el caso del reino visigodo no lo hemos visto con anterioridad (creemos que se debe al limitado número de fuentes y a la pervivencia de valores sociales y culturales asociados a una identidad romana).

\section{El juramento de fidelidad}

El vínculo de fidelidad es entendido por la mayoría de los visigotistas como un elemento cohesionador del reino godo en un contexto de feudalización ${ }^{528}$. Frighetto considera que

${ }^{527}$ Este problema fue planteado por Sánchez Albornoz de forma intuitiva, pero nunca lo desarrolló. SÁNCHEZ Albornoz, C.: "El Aula Regia y las asambleas políticas de los godos". p. 20 y 21.

${ }^{528}$ BARBERo, A. \& VigIL, M: La formación del feudalismo en la Península Ibérica ... pp.126-154. Estos autores analizan en estas páginas los aspectos de los juramentos de fidelidad personales y de todos los habitantes del reino en clave feudal. Consideran que " (...) las vinculaciones de tipo personal al monarca, por medio de un juramento de forma generalizada, eran esenciales para tratar de mantener la unidad política del reino". Opinión repetida por LORING, Ma. I., PÉREZ, S. Y FUENTES, P.: La Hispania tardorromana y visigoda..., “(...) la unidad del reino se mantendrá a través de vínculos de fidelidad que supondrían el reconocimiento del rey por parte de los poderosos del reino". p. 270, y Valverde Castro que, en un apartado sobre la evolución histórica del juramento de fidelidad, considera “(...) la terminología empleada en la Hispania visigoda para hacer referencia a la lealtad jurada por el conjunto de la población al rey es de origen romano. El carácter público que adquiere el juramento como vínculo cohesionador de la organización socio-político existente hunde sus raíces en el mundo romano (...) Teniendo en cuenta dicha funcionalidad política, es decir, puesto que mediante el juramento de fidelidad, que se ha convertido en el principal vínculo de unión entre el soberano y sus súbditos, se trata de cohesionar la organización socio-política del reino (...)", VALVERDE CASTRO, Ma. R.: Ideología, simbolismo y ejercicio del poder real en la monarquía visigoda..., pp. 222 y 223. García Moreno no duda en hablar de una jerarquización protofeudal pues “(...) en el Reino visigodo de la segunda mitad del siglo VII se había formado una auténtica jerarquía vasallática (Lehnshierarchie) que abarcaba prácticamente a todos los miembros de la clase dominante", GARCíA Moreno, L.A.: Historia de la España visigoda..., p. 253, King, después de abordar la documentación sobre el vínculo de fidelidad y sus implicancias materiales, concluye: “ (...) pecaríamos de prudencia excesiva si no concluyéramos que el rasgo fundamental del feudalismo en su sentido más estricto, militar, existió ya en el reino visigodo del siglo VII: si no podemos llamar feudal al estado visigodo, podemos, al menos, hablar con razón de feudalismo visigodo." KING, P.D.: Derecho y sociedad en el reino visigodo..., p. 81 . 
"la realización del juramento de fidelidad de parte de todos — gentes y pueblo, laicos y clericales - , sería visto como un medio evidente del fortalecimiento de la propia institución monárquica acosada, como sabemos, por un intenso proceso de inestabilidad sucesoria causado por las constantes disputas entre los distintos grupos de la nobleza, detentadores de vastísimos poderes a nivel local y regional”,529.

En un sentido similar, Díaz Martínez y Poveda sostienen que, en un contexto de competencia entre facciones aristocráticas por el trono, el juramento de fidelidad fue una forma de "blindar la figura del monarca", siendo un mecanismo que regulaba la relación entre el rey y la aristocracia ${ }^{530}$.

El análisis del juramento de fidelidad visigodo ocupa un espacio relativamente breve en las obras de los especialistas actuales, en parte, creemos, por las pocas fuentes existentes sobre ello y por ser un tópico muy trabajado por la rama de la historiografía tradicional.

Los reyes visigodos fueron objeto de una doble fidelidad: una general y pública, dada por todos los súbditos, y una segunda, especial y personal dada por los fideles regis ${ }^{531}$. Sobre la segunda nos detendremos, pero antes repasaremos las implicancias del juramento que se esperaba de todos los habitantes del reino o por lo menos de todos los ingenuos. La fórmula del juramento de fidelidad que el pueblo le debía al rey la encontramos en numerosos pasajes de las actas conciliares, como hemos visto en el capítulo anterior. La primera vez que se aludió al juramento de fidelidad (y a las consecuencias de su ruptura) fue en el IV Concilio de Toledo; allí se dispuso que faltar a la promesa realizada al rey equivaldría a prevaricar contra Dios y su castigo no podría ser menos que la excomunión. Leyendo los términos que

\footnotetext{
${ }^{529}$ FRIGHETTO, R.: "Incauto et inevitabili conditionum sacramento: juramento de fidelidad y limitaci ón del poder regio en la Hispania visigoda en el reinado de Egica (688)." Intus Legere Historia [En línea], 1.1-2, 2007, pp. 67-79, p. 70.

${ }^{530}$ DíAz MartíneZ, P. C. y PovedA, P.: “Qui patrie excidium intulerunt. Hispania 711: explicaciones desesperadas para un colapso inesperado", Reti Medievali, 17/2, 2016, p. 7.

Dice Sánchez Albornoz: "En la época visigoda la palabra fideles se empleó en España, en texto legales y canónicos, para designar a los miembros de la Iglesia Católica; pero en unos y en otros y en las fuentes narrativas se aplicó, también, a quienes se hallaban ligados a alguien por un juramento de lealtad. Porque todos los habitantes del reino le prestaban al príncipe, se llamó fideles a los súbditos (...) Y porque algunos súbditos, a más de su promesa general al rey en calidad de tales, le juraban una fidelidad especial, voluntaria y espontánea, el Liber y las actas de algunos concilios toledanos llaman fideles regis al grupo restringido de personas al servicio jurado del príncipe", En torno a los orígenes del feudalismo... p. 41 y 42.
} 
se utilizaron para la formulación del canon es evidente que la promesa de la fidelidad había sido una costumbre arraigada y de larga data ${ }^{532}$.

En concreto, el contenido del juramento - que se fue ampliando según transcurría el siglo - podemos resumirlo así: el pueblo prometía respetar a la persona del rey no causándole perjurio, ni dándole muerte, ni tomando para sí la dignidad del reino; del mismo modo, se hicieron votos con el fin de proteger a la familia regia, a la patria y al pueblo godo. El principal objetivo de los reyes fue, sobre todo, asegurar la fidelidad de los maiores del reino. Consideramos que las indicaciones realizadas en los Concilios en pos de salvaguardar al rey y a su círculo íntimo estuvieron relacionadas con los problemas que experimentaron los reyes que convocaron cada Concilio. Por lo tanto, estas leyes fueron el fruto de circunstancias peligrosas para los jefes del reino, al igual que la ley de Égica sobre la fidelidad al rey ${ }^{533}$, como lo expuso García López Yolanda sobre esta misma norma (esta autora conjetura que la ley 2, 1, 7 fue promulgada por Égica con la intención de legitimar a Witiza como su corregente y así sortear los peligros que se le presentaron ${ }^{534}$ ).

Volviendo sobre el juramento, distinguimos dos sectores sociales que debían prometer su fidelidad al rey: los ingenuos y la aristocracia. El clero, tratado como un segmento social aparte, también fue impelido a jurar fidelidad al rey, como lo indican el canon primero del séptimo Concilio de Toledo del año $646^{535}$ y el segundo del X Concilio de Toledo del $656^{536}$. No sorprende que los reyes hayan exigido la jura de los eclesiásticos, pues estos participaron activamente de la política del reino tramando sublevaciones y ocupando puestos claves en más de una destitución regia, como apuntamos en las reconstrucciones de las revueltas contra Recaredo y Wamba. Como lo señala Frighetto, es sumamente interesante esta norma ya que contradice todas las disposiciones contenidas en la legislación tardoimperial y constituirían una novedad jurídica. ${ }^{537}$

\footnotetext{
${ }^{532}$ Concilios, Toledo IV, c. LXXV, p. 217.

${ }^{533} \mathrm{LV}, 2,1,7$, "De his qui ob noui principis fidem seruandam iuare distulerint, uel illis qui ex palatino officio ad eius demobu idemdam presentiam uenirene clexerint o De fidelitate novis principibus reddenda et pena huius trasgressionis".

${ }^{534}$ GARCÍA LÓPEZ, Y.: Estudios críticos y literarios de la "Lex Wisigothorum ..., 372 y ss.

${ }^{535}$ Concilios, ToledoVII, año 646, c.I, p. 249 y 250.

${ }^{536}$ Ibidem, ToledoX, año 656, c. II, p. 310.

${ }^{537}$ FrighetTO, R.: "Incauto et inevitabili conditionum sacramento: juramento de fidelidad y limitaci ón del poder regio en la Hispania visigoda en el reinado de Egica (688).", p. 70.
} 
Ahora bien, las promesas de fidelidad hechas por cada clase estamental del reino tuvieron naturalezas distintas. La norma egicana citada más arriba nos ayudará a entenderlas.

La razón de la ley 2, 1, 7 fue prescribir que todos los hombres libres del reino jurasen fidelidad al príncipe: los miembros del Oficio Palatino en persona y los ingenuos ante un discussor iuramenti (delegados del rey calificados para tomar por escrito el juramento). Égica convocó tanto a los libres como a los aristócratas palatinos, pero el verdadero peso de la ley cayó en éstos últimos.

Con respecto a los ingenuos, la relación contraída con el rey sería entendida como una relación de súbditos “(...) cuyo carácter es general y responde a la necesidad de establecer vínculos públicos de unión (...) ${ }^{938}$. La promesa de fidelidad creaba un pacto cuya ruptura tenía un costo muy alto, por este motivo la ley castigaba duramente a aquellos que habiendo recibido el aviso sobre el nuevo rey no se encontraban donde debieran para prestar el juramento. Eludir a los delegados del rey implicaba no querer realizar la jura por él, por lo tanto, sublevarse o participar en cualquier atentado contra el mismo o simplemente desobedecerlo no habría podido ser considerado un acto de traición puesto que antes no se había prometido la fides $^{539}$.

Ahora bien, ¿quiénes eran estos ingenuos que por la fuerza de la ley debieron jurar fidelidad al rey? ¿Eran todos los hombres libres o solo aquellos que poseyeron su independencia política y un potencial militar capaz de generar un frente opositor y/o integrarse a las filas de la aristocracia enemiga al rey? ¿Por qué tanto interés de parte de Égica de conseguir la fidelidad prometida?

De forma llamativa, la ley omitió regular sobre aquellos que ya se habían encomendado a otros potentes, reconociendo tal vez su incapacidad de involucrarse en otra

\footnotetext{
538 VALVERdE CASTRO, Ma. R.: Ideología, simbolismo y ejercicio del poder real en la monarquía visigoda... p. 220.

${ }^{539}$ En las Capitulares de Carlomagno este problema ya había sido detectado: “Quam ob rem istam sacramenta sunt necessaria, per ordine ex antiqua consuetudine explicare faciant, et quia modo isti infideles homines magnum conturbium in regnum domni Karoli regi voluerint terminare et in eius vita consiliati unt et inquisiti dixerunt, quod fidelitatem ei non iurasset” Cap. Vol, I, c. 25. Sobre el juramento de fidelidad en el Imperio Carolingio ver: DAVIS, J. R.: Charlemagne's practice of empire, Cambridge: Cambridge University Press, 2015. pp. 411 y ss. MCKITTERICK, R.: Charlemagne: The formation of a European identity. Cambridge: University Press, 2008. Nelson, J. L.: «Elites in the Reign of Charlemagne», en BougARD, F., GoETZ, H.-W., LE JAN, R. (eds.) Théorie et pratiques des élites au Haut Moyen Âge. Conception, perception et réalisation sociale, Turnhout: Brepols Publishers, 2011, pp. 309-324.
} 
relación de fidelidad. Entonces, los hombres libres sin vínculos personales deberían responder solamente al rey. Podemos especular que la primera parte de la normativa egicana tuvo como finalidad sustraer a los hombres libres de la órbita de otros aristócratas, y así esperar que integren sus huestes por la fuerza del vínculo forjado por la vía legal. De cumplirse la norma, el rey pudo esperar una respuesta militar casi inmediata por parte de una gran cantidad de hombres ante un ataque doméstico o procedente del extranjero y así fortalecer su posición como gobernante.

En su segunda parte la norma obligaba a los miembros de la aristocracia a prestar juramento al rey en persona; esta práctica no era nueva, aunque introducía dos aspectos innovadores. El primero de ellos radicó en la instauración de una pena muy fuerte para aquellos que se negasen a cumplir el mandato. Égica dispuso para los palatinos que no juraran su fidelidad en persona la sentencia de quedar bajo el arbitrio de la autoridad regia (ex ordine palatino fuerit minime regis obtutibus se presentandum ingesserit, quiquid de eo uel de omnibus rebus suis principalis auctoritas facere uel iudicare uoluerit, sui sit incunctanter arbitrii).

Por lo tanto, la aristocracia como clase fue obligada por las leyes a jurar fidelidad al rey; sin embargo, desconocemos el alcance de este mandato legal. Por otra parte, si este juramento se llevó a cabo no resultó finalmente una herramienta muy eficaz ${ }^{540}$, pues se ha visto cómo una y otra vez la aristocracia se sublevó a sus reyes. Este aspecto está íntimamente ligado a la segunda innovación de esta ley que fue, como lo señaló García López, asegurar la fidelidad por la vía coercitiva ${ }^{541}$.

García López planteó una conclusión sumamente reveladora sobre la ley 2, 1, 7; la comparó con las disposiciones conciliares sobre la fidelidad debida al rey y con pasajes de Gregorio de Tours, Isidoro de Sevilla y Julián de Toledo, y dedujo que

"los textos citados nos enfocan de forma concreta cuál era la doctrina que sobre ella se
predicaba en ese momento desde el sector culto eclesiástico a un público que sería, al fin y al
cabo, también el principal receptor del código: a saber, que una promesa vi exacta no tiene

\footnotetext{
${ }^{540}$ Sostienen esta idea: KING, P.D.: Derecho y sociedad en el reino visigodo..., p. 61. FRIGHETTO, R.: "Incauto et inevitabili conditionum sacramento: juramento de fidelidad y limitaci ón del poder regio en la Hispania visigoda en el reinado de Egica (688).", p. 71.

${ }^{541}$ GARCÍA LÓPEZ, Y.: Estudios críticos y literarios de la "Lex Wisigothorum"..., p. 363.
} 


\section{la misma validez moral que una voluntaria, y que este principio era aplicable al juramento de fidelidad al rey" 542}

Es por demás estimulante esta conclusión, puesto que nos alienta a seguir trabajando sobre uno de los aspectos de la relación de fidelidad aristocrática del cual ya habíamos puesto en aviso: su carácter reciprocitario y contractual. Ya vistas las propiedades formales y legales del juramento de fidelidad, continuaremos con su análisis poniendo énfasis en la identidad de los involucrados y sus implicancias materiales y políticas.

Los fideles regis: identidad y funciones

Los reyes esperaron la fidelidad del pueblo y de la aristocracia, pero no siempre la obtuvieron. Sin embargo, como señala Sánchez Albornoz, sí existió un grupo de hombres que mantuvieron con el rey un vínculo especial de fidelidad: los fideles regis. En un análisis del léxico utilizado por las fuentes legales el historiador abulense descubre que el genitivo regis solo se empleó con relación a

“ $1{ }^{\circ}$ hombres o cosas vinculadas al rey por relaciones de índole privada y personalísima (...). $2^{\circ}$ A calidades de su persona (...). $3^{\circ} \mathrm{A}$ su autoridad o potestad de soberano o a las más directas emanaciones de su voluntad de príncipe o de hombre (...). $4^{\circ} \mathrm{A}$ ceremonias, actos o servicios, $(\ldots)^{9543}$

Por consiguiente, cuando las fuentes nombran a los fieles al rey están aludiendo a miembros de la aristocracia vinculados a través de un juramento de lealtad, que tal vez se plasmaría por escrito ante testigos. Esta relación tuvo un carácter sacro, por lo tanto, su ruptura ha sido considerada como un acto de perfidia hacia Dios y no se tomaba a la ligera.

En el Concilio de Toledo VI del año 638 reunido bajo el mando de Chintila, en su decimotercer canon se pidió a los jóvenes y los hombres minores honrar a aquellos que en el palacio eran tenidos en gran consideración por su mérito, o por sobresalir en dignidad, en reverencia o por favor del rey ${ }^{544}$; el siguiente canon 1 leva como título De remuneratione

\footnotetext{
${ }^{542}$ Idem, p. 364 y 365 . El subrayado es nuestro.

543 SÁnchez AlbornOz, C.: En torno a los orígenes del feudalismo... pp. 47 y 48.

${ }^{544}$ Concilios, ToledoVI, año 638, c. XIII, p. 241.
} 
conlata fidelibus regum. Estos dos cánones podrían entenderse como un tándem: el primero de ellos revela las vías posibles para pertenecer al círculo íntimo del rey y el segundo las obligaciones para con el rey y de este para con ellos, así como el castigo dispuesto en caso de fallar en su propósito. Volveremos sobre esto más adelante. Pero ¿quiénes fueron los fideles regis? ¿Cuáles fueron sus funciones y obligaciones para con el rey? ¿Por qué fueron piezas centrales en la dinámica política del reino?

Con relación a la primera pregunta, los indicios documentales permiten delinear con bastante exactitud quiénes eran los fideles regis, aunque los documentos contengan información muy parcializada. Isla Frez plantea que los miembros del officium palatinum o aula regia, es decir el grupo que rodeó a los reyes y administró junto a ellos el reino, fueron por antonomasia los fideles del rey $^{545}$. Estos proporcionaban consejo y auxilio al rey, cogobernaron con el príncipe administrando circunscripciones del reino y participaban en asuntos de gobierno. Los palatinos gozaron de los cargos de procer, dux, comes, y gardingus, los cuales conformaron una jerarquía que generaba desigualdades dentro del seno de la aristocracia. C. Martin demostró que la dignidad de procer cayó en desuso hacia la mitad del siglo VII, y que el honor de dux fue la más alta de las dignidades. Asimismo, el título de gardingo se utilizó solo a finales del reino y se aplicó a los jóvenes ${ }^{546}$. Las lecturas de los Concilios dan cuenta de que el grupo que acompañó al rey estaba constituido por grandes magnates, mas ¿todos ellos fueron fideles regis? Isla Frez propone que "Salvo (...) ocasiones particulares, las fuentes apuntan a que la más alta aristocracia está toda ella en el officium palatinum" 547 , y entonces siguiendo el razonamiento de Isla Frez, toda la alta aristocracia perteneció al oficio palatino y, por lo tanto, fueron fideles regis. Acordamos parcialmente con el resultado de este razonamiento deductivo. El análisis de las funciones de los fideles regis y su identidad mostrarán los fundamentos de nuestra parcial negativa.

\footnotetext{
545 ISLA FREZ, A.: "El < officium palatinum> visigodo. Entorno regio y poder aristocrático", Hispania: Revista española de historia, 212 (2002), pp. 823-847, p. 827.

546 Sobre este término ver: SÁnCHEZ AlBORnOZ, C.: En torno a los orígenes del feudalismo... pp. 77-106; Wolfram, H.: History of the Goths, California, 1990, p. 242; Thompson, E. A: The goths in Spain... p. 335; MARTIN, C.: "Hiérarchie et service dans le monde wisigothique: la militia des laics", en BougARD, F., IOGNAPRAT, D. and LE JAN, R. (eds.): Hiérarchie et stratification sociale dans l'Occident médiéval (400-1100). Turnhout: Brepols Publishers, 2008, p. 332.

${ }^{547}$ ISLA FREZ, A.: "El <officium palatinum> visigodo..."
} 
La estructura de gobierno de los reyes visigodos no tuvo un entramado particularmente denso, a pesar de que desde Toledo se pretendió enviar directrices a todas las regiones que pretendía gobernar ${ }^{548}$. Los reyes estaban obligados a acudir a una red de miembros del palacio para que sus órdenes se cumplieran en un reino que era dirigido de forma heterogénea ${ }^{549}$. Los distintos desempeños de los fieles al rey ayudaron al funcionamiento del gobierno regio.

En el III Concilio de Toledo un grupo llamado seniores Gothorum firmó la condenación de la herejía arriana cada uno de ellos bajo el título de vir inluster ${ }^{550}$. En el año 633 a Sisenando lo acompañó un grupo de varones magnificentissimis et nobilissimis al Concilio reunido en la iglesia de Santa Leocadia ${ }^{551}$. La fuerte presencia de los fideles regis junto al rey en los Concilios la encontramos también con Chintila. En las actas del Concilio de Toledo V, se describe que éste ingresó a la iglesia junto a optimates y señores del palacio, para luego encomendarse a las oraciones y obligó a sus fideles a hacer lo mismo con una santa exhortación ${ }^{552}$. La Crónica Mozárabe del 754 cada vez que informa sobre la convocatoria regia a un Concilio registra la participación del rey y de los palatii senioribus ${ }^{553}$.

Durante el reinado de Chindasvinto, se promulgó una ley que ordenaba que las amnistías a los criminales que hubiesen cometido delitos causa gentis et patrie solo podrían concederse si el rey contaba con la aprobación de los obispos y los mayores del palacio ${ }^{554}$. Recesvinto se refirió a un grupo de varones ilustres en estos términos: "plebium rectores exegit, quos in regimine socios, in adversitate fidos et in prosperis amplecturos stenuos " Wamba en rol de vir inluster presentó el testamento de san Martín de Braga ante la asamblea

\footnotetext{
${ }^{548}$ Para el tratamiento de la organización de las estructuras gubernamentales ver principalmente: SÁNCHEZ ALbORNOZ, C.: "El Aula Regia y las asambleas políticas de los godos"; KING, P.D.: Derecho y sociedad en el reino visigodo..., $\mathrm{p}$ 72- 104. VALVERDE CASTRO, $\mathrm{M}^{\mathrm{a}}$. R.: Ideología, simbolismo y ejercicio del poder real en la monarquía visigoda..., pp. 236, 226 y 243.

${ }^{549}$ MARTín VISO, I.: "Colapso político y sociedades locales: el Noroeste de la península ibérica (siglos VIIIIX)".

${ }^{550}$ Concilios, Toledo III, año 589, rúbricas, p.123.

${ }^{551}$ Ibidem, Toledo IV, año 633, p. 186

${ }^{552}$ Ibidem, Toledo V, año 636, acta de apertura, p. 226.

${ }^{553}$ Chronica muzarabica anni 754, p. 34; también los nombra como "palatinum collegium" p. 40; "officium dignissimum palatinum”, asímismo en: pp. 46, 54, 56; 58 y 63.

${ }^{554} \mathrm{LV}, 6,1,7$. p. 256. “(...) Quod si divina miseratio tam sceleratis personis cor principis misereri conpulerit, cum adsensum sacerdotum maiorumque palatii licentiam miserandi libenter habebit”. Ver para el contexto de esta ley: MARTIN, C.: "Des fin de regne...". p. 210.

${ }^{555}$ Concilios, Toledo VIII, año 653, discurso de exhortación de Recesvinto, p. 265.
} 
conciliar reunida en Toledo en el año 656 para someterlo a discusión por los presentes ${ }^{556}$. A ellos se los reconoció también como agentes de la justicia: en el año 673 en el juicio contra Paulo y cincuenta y tres jefes locales (todos ellos de notable estirpe) Wamba en persona presidió el juicio acompañado por los señores del palacio ${ }^{557}$; el canon segundo del Concilio de Toledo XIII, convocado por Ervigio en el año 683, decretó que aquellos acusados de algún delito no fueran despojados de las prerrogativas de su categoría de forma brutal, sino que en pública deliberación de los sacerdotes, de los señores y de los gardingos fueran interrogados con toda justicia, y si se hallasen culpables sufrirían las penas que las leyes señalaban o serían declarados inocentes por el juicio de todos ${ }^{558}$. En ocasión de promulgar una ley tocante a los judíos, Sisebuto enunció que lo hizo omni cum palatino officio ${ }^{559}$.

La movilización de las tropas militares constituyó la empresa más importante de los fieles al rey. Si bien debemos destacar que al asumir la investidura el rey se convertía en jefe del ejército encargado de la seguridad del reino ${ }^{560}$, la tarea de aquél fue proporcionar guerreros listos para luchar por el rey y comandar sus tropas si fuese necesario. Esta tarea recaía en los duces (generales del ejército), quienes, según C. Martin, estaban en su cargo sólo por el tiempo que duraba la campaña ${ }^{561}$. Ya hemos visto al duque Claudio combatir a los francos por Recaredo y a Paulo en nombre de Wamba tomar la misión de reprimir a los sublevados antes de convertirse en su líder ${ }^{562}$. Isidoro anota como triunfo militar de Witerico la captura de unos soldados imperiales en Sagontia (a unos 15 kilómetros de Medina Sidonia, en Baños de Gigonza ${ }^{563}$ ) por parte de sus duques ${ }^{564}$. Rechila combatió a los astures y Suintila

\footnotetext{
${ }^{556}$ Ibidem, Toledo X. p. 322.

${ }^{557}$ IUL. TOL. HW, p. 254.: "Hic igitur sceleratissimus Paulus, dum, couocatis adunatisque omnibus nobis, id est senioribus cunctis palatii, gardingis omnibus omnique palatino officio (...)”.

558 Concilios, Toledo XIII, año 683, c. II, p. 417.

${ }^{559} L V, 12,2,14$, p. 420.

${ }^{560}$ DÍAZ MARTínEZ, P. y VALVERDE Ma . R.: "The theoretical strength and practical weakness of the visigothic monarchy of Toledo". El rey presidía las campañas militares en persona acompañado por una comitiva: el canon III del Concilio de Mérida del año 666, bajo reinado de Recesvinto, instó a realizar un oficio religioso para que por intercesión divina se conservase la vida del rey, la de sus fieles y de todo el ejército en tiempos de guerra. Concilios, Mérida, año 666, c. III, p. 327. Wamba pidió consejo a los cuatro duques con él reunidos sobre la táctica bélica a seguir.

${ }^{561}$ MARTin, C.: "Hiérarchie et service dans le monde wisigothique: la militia des laics”, p. 329.

562 IUL. TOL. $H W$, p. 224.

${ }^{563}$ VIZCAÍNO SÁNCHEZ, J.: La presencia bizantina en Hispania, siglos VI-VII: la documentación arqueológica, Serie Antigüedad y Cristianismo, Universidad de Murcia, 2009, p. 147.

${ }^{564}$ ISID. Hist. Goth., p. 268.
} 
venció a los rucones y se apoderó de algunos espacios ocupados por los bizantinos; ambos personajes lo hicieron siendo duques de Sisebuto ${ }^{565}$.

El rol de la aristocracia en la organización del ejército fue central y su examen abre problemas que merecen un capítulo exclusivo, pero para continuar el estudio sobre los fideles regis adelantaremos algunas conclusiones obtenidas en las páginas venideras. En primer lugar, el alistamiento de guerreros que estaban dispuestos a luchar bajo el estandarte regio no fue una tarea sencilla, pues cada grupo de guerreros respondía al jefe aristocrático que lo había reclutado. De los datos que proporcionan las fuentes sobre el carácter de las tropas y la dificultad de su enrolamiento, se desprende que el poderío regio ante una guerra o revuelta aristocrática estuvo sujeto, en gran medida, al éxito de la convocatoria y al apoyo de los grandes del palacio y de sus seguidores ${ }^{566}$. El sostén político y la fuerza de las alianzas se manifestaban materialmente en milicias dispuestas a secundar al rey en las batallas.

Decretar leyes, impartir justicia y comandar ejércitos no fueron las únicas tareas que cumplían los grandes junto al rey y en su nombre; el gobierno de las ciudades y su territorio circundante estuvo bajo el mando del comes civitatis y las provincias bajo el mando de un dux o rector provinciae ${ }^{567}$, miembros de la aristocracia designados por el rey para tales funciones. Tanto la administración del reino como los cargos fueron evolucionando. García Moreno considera que, siguiendo el modelo bizantino, hubo un proceso de militarización de la administración durante la segunda mitad del siglo VII ${ }^{568}$. Por su parte, C. Martin niega este proceso, y argumenta que las reformas realizadas por Chindasvinto y Recesvinto no asignaron funciones civiles a los militares y que el uso de términos marciales en la administración se debió al contexto mental de la Antigüedad Tardía, constituyendo solo un fenómeno discursivo. Es muy difícil brindar una opinión acabada sobre la organización administrativa del reino godo porque el carácter de las fuentes dificulta un estudio sistemático. Sin embargo, creemos que la opinión de García Moreno en relación con el

\footnotetext{
565 ISID. Hist. Goth., p. 272 y 274.

566 DíAz MARTíneZ, P.C. y VALVERDE M.R.: "The theoretical strength and practical weakness of the visigothic monarchy of Toledo".

${ }^{567}$ ISLA FREZ, A.: "El <officium palatinum> visigodo. Entorno regio y poder aristocrático", Hispania, LXII/3, 212, 2012. pp. 838.

568 GARCÍA MoRENO, L. A.: "Estudios sobre la organización administrativa del reino visigodo de Toledo", Anuario de Historia del Derecho Español, t. XLIV, Madrid, 1974. MARTIN, C.: La géographie du pouvoir..., p 167 y p. 176 y ss.
} 
problema anterior es válida, pues la nueva naturaleza que adquirió la administración podría ser una consecuencia lógica derivada de la militarización cultural que experimentó la aristocracia temprano medieval.

Isla Frez, siguiendo de cerca los lineamientos propuestos por Sánchez Albornoz, ${ }^{569}$ destaca que los cargos de los distintos aristócratas que aparecen firmando las actas de los Concilios como comes cubiculi, comes patrimonii, comes notariorum, comes stabuli, comes spatarius, comes scanciarum, comes thersaurorum, fueron cargos honoríficos, sin que ello se convierta en impedimento para que estos condes hayan desempeñado alguna función específica. A su vez plantea que este carácter honorífico tampoco entorpeció el desarrollo de una carrera (cursus honorum) dentro del órgano de gobierno; como ilustra el caso de Teodemundo quien obtuvo un ascenso desde su condición de spatarius ${ }^{570}$ a procer. Por su parte, C. Martin postula que es indemostrable la existencia de una carrera con la documentación disponible. Sin embargo, pensamos que más allá de las funciones y de las posibles promociones, la aristocracia no formó cuadros de especialistas gubernamentales; de hecho, los miembros del oficio palatino, llamados en el siglo VII seniores palatii ${ }^{571}$, obtenían sus cargos como recompensas por el apoyo político dado al rey o por el servicio de consejo y auxilio prestado en carácter de fieles al rey. King sostiene que los comites obtenían su cargo/título por la relación especial que los unía al rey, pues nadie mejor que sus “compañeros” desempeñarían las obligaciones que los puestos otorgados conllevaban ${ }^{572}$. La misma C. Martin argumenta — matizando la idea que la aristocracia visigoda fue una "nobleza de servicio" 573 que reemplazó a la nobleza de sangre- que el rey poseía la potestad

\footnotetext{
${ }^{569}$ SÁnChez AlbornOz, C.: "El Aula Regia y las asambleas políticas de los godos”, en pp. 36 y ss.

${ }^{570}$ Con respecto a este cargo, Isla Frez dice: “(...) Podrían ser meros guardianes, pero su relevante posición como comites, (...) y su número en el XIII concilio nos hacen pensar que son lo jefes de la guardia palatina." Los espatarios eran miembros de la alta aristocracia; además, este autor, siguiendo los datos obtenidos de las Crónica de Alfonso II sobre la condición de spatarius de Pelayo, propone que los jóvenes de la más alta alcurnia comenzaban sus servicios al rey como spatarii. ISLA FREZ, A.: "El <officium palatinum> visigodo. Entorno regio y poder aristocrático" .., p. 836.

571 “(...) seniores palatii, (...) aristócratas godos que pertenecían al palatium establecido en Toledo, acabarán siendo consejeros reales, en particular, en cuestiones de índole legislativa y judicial". MORENO RESANO, E.: "El título de senior en la Antigüedad tardía: un estudio de terminología institucional”, Saldvie, 13-14 20132014, p. 149.

572 KING, P.D.: Derecho y sociedad en el reino visigodo..., p. 74 y ss.

${ }^{573}$ SÁnChEZ AlbornOZ, C.: “El Aula Regia y las asambleas políticas de los godos”, pp. 150 Y 252.
} 
de elegir a quién otorgar una función dentro del Oficio Palatino ${ }^{574}$; sin embargo, debería respetar el mérito del candidato, es decir, asevera la autora, su origen distinguido y sus cualidades morales (origo et uirtus); por lo tanto, el rey elegiría quiénes eran beneficiados con los cargos entre los miembros del "Gotorum nobiles genere" criterios hizo que las opciones del rey estuviesen limitadas a un grupo específico; además le permitió a este grupo asegurarse posiciones de privilegio en los asuntos del gobierno central, obstruyendo la entrada de sujetos por fuera del círculo de la clase dominante.

Veremos para iluminar lo expuesto los recorridos de varios miembros de la aristocracia de los cuales poseemos suficientes datos para reconstruir parte de sus trayectorias políticas.

En las actas del VIII Concilio de Toledo presidido por Recesvinto, el pliego regio fue estudiado y discutido por los obispos reunidos y ciertos varones ilustres provenientes del oficio palatino, quienes según Recesvinto fueron "plebium rectores” y sus socios en el gobierno. Entre estos socios se encontraba Paulo, cuya firma plasmó en la resolución conciliar como conde de los notarios en octava posición entre dieciocho ${ }^{576}$. Dos años después, firmaba con el mismo título las actas del IX Concilio de Toledo, esta vez ocupando el primer lugar entre cuatro. En el año 672, Paulo ejerció como dux bajo el reinado de Wamba. Una vez penado por sus acciones traicioneras queda por un tiempo fuera del registro documental. Años más tarde, y pasado un breve periodo de asumido el trono, Ervigio perdonó a los castigados por su antecesor (no existe referencia clara del origen de la culpabilidad, sólo se sabe que habían obrado contra la potestad regia, pero es factible suponer que fueron los condenados por Wamba, ya fuese en el juicio contra Paulo y sus cómplices o por la ley militar), es más, los favoreció y los recibió en su mesa (“...sed quos regia potestas aut in gratiam benignitatis receperit aut participes mensae sua effecerit..."577), esto significa que restauró su estatus perdido por las penas recibidas y les permitió participar en los asuntos del

\footnotetext{
574 Sobre la historia y evolución del Oficio Palatino ver: SÁNCHEZ ALBORNOZ, C.: “El Aula Regia y las asambleas políticas de los godos" ...

${ }^{575}$ MARTIN, C.: "Hiérarchie et service dans le monde wisigothique: la militia des laics", p. 332. Para el problema de la identidad étnica de la clase dominante ver: MARTIN, C.: "La notion de gens dans la péninsule Ibérique des VI-VIIe s. : quelques interprétation”, en GAZEAU, V., BAUDUIN, P., MODÉRAN, Y. (eds.):"Identité et ethnicité : concepts, débats historiographiques, exemples (IIIe-XIIe siècle)", Caen: Publications du CRAHM, 2008b, p. 75-89.

576 Concilios, Toledo VIII, año 646, rúbricas, p. 289.

${ }^{577}$ Ibidem, Toledo XII, año 681, c. III, p. 389.
} 
reino. Por esta oración podemos aseverar que en el XIII Concilio de Toledo del año 683 encontramos las firmas de cuatro de los implicados en la revuelta contra Wamba: Wadamirus, comes scanciarum, Trasericus, spatarius et comes, Trasimirus, procer y Recaulfus, procer $^{578}$. Pasado el reinado de Ervigio, Traserico firma las actas conciliares del año 688 ya bajo gobierno de Égica nuevamente como conde. Finalmente, en el año 693, encontramos a un Paulo que firma las actas del XVI Concilio de Toledo como conde.

Creemos que es posible que este Paulo sea el mismo que comandó la rebelión contra Wamba; a pesar de haber pasado veinte años de su sublevación y casi cuarenta de su primera firma, pues el tiempo transcurrido es acorde con la vida de un aristócrata visigodo y no sería una excepción encontrar un personaje de avanzada edad con una gran influencia política ${ }^{579}$; además, algunos de sus compañeros de rebelión compartieron parte de su trayectoria política (aunque Traserico pudo haber sido mucho más joven, ya que firmó como spatarius), haciendo que nuestra suposición adquiera verosimilitud.

La información que proporcionan las Crónicas del ciclo astur sobre la relación entre estos reyes genera más problemas que la edad de los personajes. En la Crónica Rotense se afirma que Égica es sobrino de Wamba por vía materna, quien en venganza impulsó el repudio a la reina por ser la hija de Ervigio ${ }^{580}$ — aunque esta acción no fue concretada, o si sucedió lo fue por muy poco tiempo porque en el año 694 el canon séptimo del XVII Concilio de Toledo declaró la protección expresa de la reina Cixila-. El dato certero es que rompió las relaciones con la familia de su suegro una vez muerto éste en el año $688^{581}$. Entonces, ¿cómo comprendemos que Égica, que claramente se enfrentó al grupo aristocrático de Ervigio, incluyó al enemigo de su tío en su oficio palatino? Posiblemente, la noticia sobre la relación de parentesco entre Wamba y Égica sea ficticia y el problema se resuelva de esta manera. Sin embargo, también la solución podríamos encontrarla si aceptamos que Égica al romper con la facción ervigiana necesitó todo el apoyo que podía conseguir y así se explicaría la incorporación de Paulo a su gobierno. Esta ruptura significó un gran golpe para la aristocracia. Veamos los datos que nos llevan hacia esta dirección.

\footnotetext{
578 Ibidem, Toledo XII, año 683, rúbricas, p. 435.

${ }^{579}$ La mayoría de los reyes vivieron hasta ver a sus hijos casarse y tener sus propios hijos adultos, como Ervigio quien entregó a su hija Cixilo a Égica, quién a su vez nombró a su hijo Witiza como su corregente.

${ }^{580}$ Chron. Rot., p. 118.

${ }^{581}$ Concilios, Toledo XV, año 688, pliego regio, pp. 449 y 450.
} 
En las actas Conciliares de los años 687 y 683 contamos con treinta y dos firmas de miembros del oficio, una de ellas pertenece a Égica y otra a Witiza, por lo tanto, contamos con treinta aristócratas de los cuales diez firman las actas del año 688 (año de ruptura con la familia ervigiana) y de esos diez solo tres lo hacen en el 693 y uno que no firmó en el 688. Esta reducción significativa de nombres estaría indicando un quiebre y un cambio en la composición del grupo regio (aunque esta información debe relativizarse, pues las firmas de las actas no reflejaban la composición total de los fideles regis, tomemos el ejemplo de la ausencia de la firma de Wamba en las actas bajo el reinado de Recesvinto ${ }^{582}$ ). Es muy posible que Égica haya construido sus bases políticas sobre el grupo que apoyó a Wamba (el cual fue afectado por las acciones de Ervigio), pero también incluyó a los grupos que quedaron por años marginados en la era wambiana y a parte del grupo ervigiano, como lo demostraría la continuidad de ciertos personajes en sus posiciones en el oficio palatino. Égica debió tejer una densa red de relaciones políticas heterogéneas para sostenerse en el puesto.

En el punto del desarrollo en el que nos encontramos podemos contestar algunas de las preguntas abiertas al principio de este apartado. En primer lugar, los fideles regis formaron una élite dentro de la clase aristocrática. No todos los miembros de la aristocracia fueron fideles regis en el sentido estricto; si bien teóricamente debían la fidelidad exigida desde las formulaciones de los preceptos ideológicos que fundamentaban el poder regio, en la práctica vemos que muchos personajes importantes manifestaban su oposición al rey de turno de manera abierta. Chindasvinto distinguió de los seniores gentis gothorum a los primates palatii en la ley 3, 1, 5, donde fijó la disposición de los bienes que constituyen la dote $^{583}$. Los cánones conciliares nos dicen que esta élite debía fiel obsequio y sincero servicio a las voluntades y mandatos del príncipe, y prestó vigilancia y custodió su vida con todas sus fuerzas. Esta descripción concuerda con los servicios que suponemos que cumplían los condes con atribuciones específicas señalados con anterioridad. Asimismo, esta élite participaba junto al rey en el gobierno del reino, como lo indica C. Martin:

\footnotetext{
582 Ibidem, Toledo VIII, año 653, rúbricas, pp. 287-289; Toledo IX, año 655, rúbricas, pp. 306 y 307.

${ }^{583}$ LV, p. 127.
} 
"La fonction, souvent appelée officium dans les sources visigothiques (mais les historiens parlent généralement d'honores), correspond à une délégation de pouvoirs par le souverain pour un temps limité ${ }^{, 584}$.

Sin embargo, no todos los fideles regis obtuvieron el mayor privilegio. Existió en el interior del círculo íntimo del rey una jerarquía que creaba desigualdades de poder y de riquezas dentro del mismo, tal como demuestra C. Martin. Esto generó una fuerte competencia por los honores que reportaban mayores retribuciones.

Por último, la composición del grupo de fideles regis había sido de carácter dinámico; la permanencia en el círculo íntimo del jefe del reino dependía del desarrollo de las relaciones políticas establecidas entre el rey y sus fieles o grupos de fieles. La entrega de recompensas y preservación de la fidelitas fueron dos aspectos claves del vínculo. Volveremos sobre estos dos últimos puntos.

Ahora bien, ¿qué sucedía con la aristocracia que por razones políticas — no por falta de mérito u origen - no pertenecía a esta élite? Las fuentes nos muestran que los vaivenes políticos, las alianzas circunstanciales y los enfrentamientos militares dejaban como saldo grupos de aristócratas al margen del gobierno central que mientras eran marginados sufrieron la remisión de sus riquezas y de su encumbrada posición social; sin embargo, y aunque su capital político y la capacidad de construir alianzas mermaban, éstas no desaparecían completamente. Años después los mismos personajes, miembros de la familia o aliados aparecían disputando espacios en el gobierno central o directamente el poder regio. Las acciones de Pablo y sus compañeros, y los muchos otros casos desarrollados a lo largo de nuestra tesis son claros ejemplos de esto. La aristocracia visigoda todo el tiempo buscó a través de las luchas políticas pertenecer al círculo íntimo del rey (Königsnähe), asegurarse una forma de reproducirse como clase en un contexto de débil explotación de la clase productora. El juramento de fidelidad fue el medio legal por el cual un lugar junto al rey era asegurado.

Don y contradon: los fideles regis y la cercanía al rey (Königsnähe)

\footnotetext{
${ }^{584}$ MARTIN, C.: "Hiérarchie et service dans le monde wisigothique: la militia des laics", p. 5.
} 
La bibliografía especializada resalta la importancia de la noción de Königsnähe para la temprana Edad Media. Por ejemplo, Wikcham establece que para la aristocracia lombarda los cargos y la cercanía al rey fueron más importantes que el linaje (de hecho, para este reino tiene un carácter marginal) o la tierra que era insuficiente para permitir grandes niveles de autonomía $^{585}$. Claramente, los visigodos se agrupaba en torno al rey esperando resultar beneficiados con cargos, honores y bienes materiales, como lo hizo el resto del conjunto de la aristocracia temprano medieval. Para los godos la mera posesión de tierras (y su explotación) no se tradujeron automáticamente en poder político; al contrario, creemos que el conjunto aristocrático veía acrecentada su posición social dentro de sus comunidades locales y su riqueza a través del ejercicio del poder político. Por lo tanto, ocupar lugares estratégicos en el gobierno junto al rey había sido un objetivo sumamente ambicionado.

La dinámica que existía en el círculo cercano del rey se podría complementar con la teoría del don de Mauss. A mediados del siglo XX los medievalistas lentamente comenzaron a introducir en sus estudios el paradigma del don para explicar desde otro punto de vista, diferente del hasta entonces dominante, la naturaleza de la economía medieval y ciertas prácticas sociales; el precursor fue Grierson en $1959^{586}$, a quien Duby sigue. Desde ese entonces, la teoría del don es aplicada en el vasto campo de los estudios medievales ${ }^{587}$.

Duby advierte sobre la naturaleza de los intercambios de bienes de carácter no comercial, a la cual llama "de las generosidades necesarias" 588 :

\footnotetext{
${ }^{585}$ WiCKHAM, C.: Una historia nueva de la Alta Edad Media ... pp. 304 y ss.

${ }^{586}$ Grierson cuestiona al comercio como único medio de intercambio de bienes. Fue el primero en advertir la importancia de las transferencias unilaterales de bienes (robo, botín de guerra, rescates) así como las voluntarias (limosnas). Grierson discute las teorías propuestas por Pirenne. GRIERSON, P.: "Commerce in the Dark Ages: a Critique of the Evidence", Transactions of the Royal Historical Society, 5 th Series, 9, pp. 123-140.

${ }^{587}$ Una propuesta que retoma, discute y redimensiona la teorías del don, del regalo y la reciprocidad para distintos periodos precapitalistas la constituye AlgaZI, G.; Groebner, V.; Jussen, B. (ed.): Negotiating the gift: pre-modern figurations of Exchange.

Para una historia del concepto del don en los estudios medievales ver: MAGNANI, E.: "Les médiévistes et le don. Avant et après la théorie maussienne". Revue $d u$ MAUSS, 2007. En línea: http://www.journaldumauss.net/?Les-medievistes-et-le-don. Una actualización reciente sobre el mismo problema: PÉREZ, M.: "Las donaciones piadosas y el modelo del don", en ASTARITA, C. (comp.): La Edad Media; recorridos historiográficos, Buenos Aires, Editorial de la Facultad de Filosofía y Letras Universidad de Buenos Aires, 2015.

${ }^{588}$ DuBY, G.: Guerreros y campesinos... p. 73.
} 
"Arrebatar, ofrecer: de estos dos actos complementarios dependen en gran parte los intercambios de bienes. Una intensa circulación de regalos y contrarregalos de prestaciones ceremoniales y sacralizadas, recorre de pie a cabeza el cuerpo social; las ofrendas destruyen en parte los frutos del trabajo, pero aseguran una cierta redistribución de la riqueza (...)"589

Con las palabras citadas comienza su análisis sobre una sociedad en la cual ningún sector social escapó de la necesidad de distribuir la riqueza acumulada, por lo tanto, de su destrucción. La aristocracia, en especial los jefes de guerra y los reyes fueron los sujetos que encontraron en esta lógica de arrebatar/ofrecer la clave de la construcción de su poder:

"En cuanto a los príncipes, su prestigio estaba en función de su generosidad: no oprimían con una avidez que parecía insaciable — sino para dar más generosamente" 590

Gurevich advierte sobre la importancia social de la riqueza, a la cual considera un arma que le permitía a la aristocracia sostener su influencia social y afirmar su honor. El comportamiento opuesto, la avaricia, provocaba el desprecio de los poderosos y campesinos, y era la largueza del aristócrata un atributo esperable y respetado. A través de la generosidad los jefes construían sus relaciones políticas y de dominio ${ }^{591}$.

En un escrito reciente, Le Jan propone demostrar la existencia de una ilación entre las crisis políticas y las prácticas competitivas de distribución de la riqueza en la Alta Edad

\footnotetext{
${ }^{589}$ Ibidem, p. 63.

${ }^{590}$ Ibidem, p. 68

${ }^{591}$ GuREVICH, A.: "Représentations et attitudes à l'égard de la propriété pendant le Haut Moyen Age", Annales E.S.C., EHESS, 27, 1972. "La richesse pour le féodal était l'arme qui lui permettait de soutenir son influence sociale, d'affirmer son honneur. La richesse en soi ne suscitait aucun respect, au contraire : le marchand qui conservait d'innombrables biens et qui n'utilisait son argent que pour le faire fructifier dans des opérations commerciales ou usuraires inspirait, dans la société médiévale, divers sentiments négatifs : l'envie, la haine, le mépris ou la peur, mais jamais le respect. A l'inverse, le seigneur qui dépensait sans compter, même s'il ne vivait pas selon ses moyens mais organisait des festins et distribuait des cadeaux, méritait respect et gloire parmi ses pairs, mais aussi parmi les bourgeois et les paysans. Du point de vue des nobles, les masses populaires ne manquaient de rien. La richesse était conçue comme un moyen d'atteindre des buts qui dépassaient de loin les limites de la seule économie. La richesse était un signe témoignant de la vaillance, de la générosité, de la largesse du seigneur. ” p. 540; “C'est sur la générosité du chef qu'étaient fondées toutes ses relations avec son entourage.(...) ” p. 538; “La générosité se trouvait au premier rang des valeurs qui caractérisaient le seigneur", p. 539

Muchas de las ideas señaladas en este artículo tuvieron un desarrollo mayor en: GUREVICH, A.: Las categorías de la cultura medieval, Madrid: Taurus, 1990.
} 
Media $^{592}$. Repasando los puntos más importantes de la teoría del don, Le Jan corrobora que los reyes de la Alta Edad Media fueron dadores de regalos en un sistema de intercambio asimétrico; a veces la distribución de los bienes de prestigio (muchas veces con un alto valor simbólico) entre los miembros de las altas esferas permitió mantener las posiciones sociales de cada uno en el orden político, en palabras de la autora: "La redistribution symbolique des richesses se trouve ainsi placée au cour de l'ordre politique et social" ${ }^{593}$.

Además, las riquezas fueron para las élites un punto clave en el proceso de dominación ya que

“1) le pouvoir donne un accès direct aux richesses

2) les hiérarchies de pouvoir et de richesse se confondent largement

3) les richesses servent à légitimer des positions de pouvoir" "594

Estas características llevaron a la élite altomedieval a acumular riquezas y luego redistribuir una parte bajo una forma más o menos ostentosa y competitiva. Asimismo, las riquezas fueron instrumentos que tuvieron fines competitivos. Y es en este último aspecto en el cual Le Jan se concentra. Retomando el concepto de potlatch de Mauss, ve concretamente que durante la Alta Edad Media en los momentos en los cuales el sistema entraba en crisis la entrega de dones tuvo un carácter agonístico, se movió bajo la lógica agresiva.

La autora constata la correspondencia entre la dilapidación de la riqueza y la inestabilidad social. Después de observar dos episodios de crisis sociales y políticas —una en la Galia del Norte alrededor de los siglos V-VI y la otra en Alemania a fines del siglo IX y principios del $\mathrm{X}$ - concluye que durante el transcurso de estas hubo una exacerbación de las rivalidades aristocrática por los recursos regios. No se desarrolló un proceso de enriquecimiento, sino que existió una lucha por el control de los lugares centrales, y durante ese proceso la aristocracia sacrificó parte de su riqueza con el fin de legitimarse en el poder.

\footnotetext{
${ }^{592}$ Recientemente, Devroey destacó la importancia de los regalos en las sociedades medievales y señaló el papel que los banquetes altomedievales tuvieron en la resolución de los conflictos, cuestionado la función agonística del despilfarro. DeVRoEY, J.P.: Économie rurale et société dans l'Europe franque (Vie-Ixe siècles), t. 1, Paris: Belin, 2003, p. 175-193.

${ }^{593}$ LE JAN, R.: "Prendre, accumuler, détruire les richesses dans les sociétés du haut Moyen Âge", en Les élites et la richesse au Haut Moyen Âge, Turnhout: Brepols Publishers, 2010, p. 366.

${ }^{594}$ Idem
} 
C. Martin analiza los reinados y corregencias de Chidasvinto/ Recesvinto y Égica/ Witiza y encuentra patrones de comportamientos que considera como eventos normales ${ }^{595}$. Estos patrones fueron: una fuerte represión emanada de los reyes hacia la aristocracia, ordenando la ejecución de sus miembros y la confiscación de sus bienes; promulgaciones de leyes civiles y convocatoria de Concilios eclesiásticos para refrendar dichas represiones; la asociación del hijo al trono del padre; y la concesión de la amnistía y beneficios a los grupos enemigos del padre por parte del hijo una vez llegado al trono. La autora resalta que en ambos casos los herederos del reino restituyeron riquezas a grupos enemigos de sus sucesores y a través de ese gesto lograron formar alianzas. Creemos que las conclusiones alcanzadas por la historiadora francesa podrían reinterpretarse desde la lógica del don.

En la misma línea de trabajo, Castellanos establece que el derecho confiscatorio regio ha sido un arma legal utilizada para castigar a aquellos que hubieran mostrado algún tipo de irreverencia para con el máximo mandatario, actitud bastante común entre los aristócratas ${ }^{596}$. También Díaz Martínez afirma que las apropiaciones de los bienes de los enemigos políticos y su posterior distribución entre sus fieles fueron un mecanismo propio de la dinámica política del reino visigodo que generó tensiones ${ }^{597}$.

Por nuestra parte entendemos a las confiscaciones como una práctica normal de los reyes que se encuadra en la lógica de arrebatar/ ofrecer/ destruir riquezas.

Entonces, establecidos los principios del marco de referencia elegido estudiaremos la entrega de los premios por parte del rey por la fidelidad prometida a sus leales aristocráticos.

Ya vimos que los fideles regis desempeñaron un papel esencial en la dinámica política del reino aportando apoyo político al rey y participando del gobierno. Tan importante había sido su peso que numerosos cánones conciliares estuvieron destinados a preservar los premios recibidos por sus méritos realizados y la fidelidad resguardada. Estos cánones nos permiten conocer, por un lado, la naturaleza de los premios otorgados, y por otro, dan cuenta

\footnotetext{
${ }^{595}$ MARTIN, C.: "Des fins de règne incertaines: répression et amnistie des groupes aristocratiques dans le royaume de Tolède (deuxième moitié du VIIe s.)"..., "Les événements observés en reflètent aucun dérèglement, mais simplement le cours normal des choses". p. 221.

${ }^{596}$ CASTEllanOS, S.: "The political nature of taxation in Visigothic Spain" ..., pp. 227-228.

${ }^{597}$ Diaz Martinez, P. C.: "Confiscations in the Visigothic Reign of Toledo". En : PorenA, P. Y Riviere, Y. (eds.), Expropiations et confiscations dans les royaumes barbares. Une aproche régionale. Roma: École française de Rome, 2012, pp. 93-112. Sigue esta línea de trabajo: POVEDA ARIAS, P.: "Relectura de la supuesta crisis del fin del reino visigodo de Toledo: una aproximación al reinado de Égica a través de sus fuentes legales".
} 
de la alta competencia que existió por estos bienes, que lejos estuvieron de sufrir un proceso de patrimonialización.

Los datos documentales relevados más abajo son los mismos que utilizan Barbero y Vigil para hablar de la plena propiedad de los bienes ganados o donados por los reyes ${ }^{598}$ en contra de los argumentos defendidos por Sánchez Albornoz considerados en esta tesis previamente- Los autores reconocen la plena propiedad, pero no dejan de señalar la capacidad de los reyes de revocar las donaciones ante el delito de infidelidad. Las traiciones eran más una norma que una anomalía en la vida política visigoda, por lo tanto, la plena propiedad de las donaciones y/o ganancias siempre había sido relativa, sujeta a la percepción del rey y condicionada por las violentas circunstancias.

En el capítulo tres constatamos las restringidas bases materiales de la aristocracia y de los reyes; ahora esa demostración permite comprender parte de las razones de los conflictos que se suscitaron alrededor de las recompensas a los fieles del rey. Disfrutar de la cercanía al rey no estuvo al alcance de cualquier aristócrata, ni permanecer en ella ha sido tarea sencilla.

El largo decreto de Recesvinto sobre el destino de los bienes confiscados por su padre, en varias partes, describe el patrimonio de los afectados como fincas, bienes de "viventium ac non viventium, inmobilium quoque et moveri valentium corpore vel specie, forma vel genere" ${ }^{\text {"599 }}$. Estos datos revelan la naturaleza de las recompensas que recibían los fieles del rey. En el 638 se consideró injusto defraudarlos en su premio, siendo estas mercedes rebus de naturaleza divina o humana. También se ordenó a los futuros reyes que no privaran sin causa de sus cargos o dignidades ni de sus bienes a aquellos que "fideli obsequio et sincero servitio voluntatibus vel iussis patuerint principis totaque intentione salutis eius custodiam vigilantiam habuerint"; muestran estas palabras que los cargos y las dignidades también fueron premios. Además, se decretó que los sucesores en el reino tratasen a cada uno de los fideles regis conforme a la utilitate de cada uno y que previeran si eran necesarios para la patria. Por último, se garantizó que todas las cosas obtenidas justamente las dispondrían a su voluntad y podrían donarlas a aquellos a quienes pluguiere. Este canon complementó el dictado tres años antes, en el V Concilio de Toledo, cuyas palabras determinaron que los

\footnotetext{
598 BARBERO, A \& VigIL, M.: La formación del feudalismo en la Península Ibérica,107 y ss.

${ }^{599}$ Concilios, Toledo VIII, año 653, p. 292 y ss.
} 
reyes respetasen los bienes adquiridos por los fieles de los reyes pasados, así se estimularía la fidelidad de los demás al notar que otros no eran privados de sus premios ${ }^{600}$.

La atribución regia de distribuir las mercedes puede ser observada ya en el siglo VI, con las acciones de Recaredo vistas más arriba, y se encuentra reflejada también en las palabras del Concilio de Toledo IV al hacer referencia a la piedad de Sisisenando: “(...) cuius gratia et bonos donorum praemiis dictat et malos a beneficentia sua congrue non separat" ${ }^{\prime 601}$. Más tarde fue reiterada en el Concilio de Toledo VIII, como ya hemos visto. La asamblea conciliar del año 653 ordenó que los bienes apropiados por el antecesor de Recesvinto se debían asentar como patrimonio de la corona y distribuir entre aquellos que eligiera $^{602}$, pues para los reunidos ningún beneficio se había llevado a cabo con ellos, ni habían servido al fisco ni se les habían otorgado como una ayuda conveniente a los oficiales palatinos $^{603}$.

Así como los reyes poseían la atribución de entregar los bienes a sus fideles y prometían cuidarlos, también tuvieron la capacidad de quitárselos. Aunque Chintila realizó la petición explícita de no arrebatar el premio otorgado a cualquier fiel sobreviviente al rey (pues si esto sucediese nadie querría servir a los reyes con prontitud y fidelidad ${ }^{604}$ ) —y la ley 5, 3, 4 exhortó a la no confiscación de los bienes de los servidores de los reyes pasados ${ }^{605}$ también ordenó incautar todo lo adquirido en forma de premios por los fieles ante un eventual acto de perfidia, o si alguno no cumpliera con lo que le había sido encomendado. De igual modo, si después de la muerte del jefe del reino se descubriese que algún fiel había conspirado contra la seguridad regia le sería incautado todo lo adquirido de la liberalidad del rey y será distribuido entre los leales ${ }^{606}$. También Chindasvinto en la ley 5, 2, 2 reguló que las donaciones regias serían confiscadas solo en caso de cometer el delito de la infidelidad ${ }^{607}$. En el Concilio de Toledo VII Chindasvinto promulgó que cualquier miembro de la Iglesia

\footnotetext{
${ }^{600}$ Ibidem, p. 229.

${ }^{601}$ Ibidem, p. 221.

${ }^{602}$ Ibidem, Toledo VIII, año 653, p 292.

${ }^{603}$ Ibidem, Toledo VIII, año 653, p 291.

${ }^{604}$ Ibidem, "Ut regum fideles a successoribus regni a rerum iure non fraudentur pro servitutis mercede", Toledo V, año 636, c. VI, p 229.

${ }^{605}$ SÁNCHeZ Albornoz, C.: El "Stipendium" hispano-godo y los origenes del beneficio prefeudal.

${ }^{606}$ Concilios, Toledo VI, año 638, c. XIV, p. 242.

${ }^{607}$ Para una interpretación de esta ley ver: BARbero, A \& VigiL, M.: La formación del feudalismo en la Península Ibérica ..., p 111.
} 
que participase de un atentado contra el rey o gentem Gothorum vel patriam ${ }^{608}$ sería apartado de su cargo y de sus bienes solo recuperaría la vigésima parte propuesta por el rey ${ }^{609}$. Hacia fines del siglo VII, Égica proclamó que los traidores se excluirían del servicio palatino sirviendo perpetuamente al fisco, sometidos al pago de los tributos y apartados de todos los bienes que el rey repartiría según su voluntad ${ }^{610}$.

La lectura de ciertas leyes y cánones de distintos Concilios permiten entender cómo funcionaba el mecanismo de las confiscaciones de manera general: están aquellos cánones que enuncian en forma de advertencia en qué casos se debía aplicar el decomiso y otros donde los mismos reyes denunciaron y revirtieron la actividad confiscatoria de alguno de sus antecesores, describiendo sucintamente lo sucedido con los bienes.

La primera confiscación regia de la cual tenemos noticia es la realizada por Leovigildo. Isidoro de Sevilla al escribir sobre Recaredo, señala que una de sus cualidades fue restituir a sus legítimos dueños las riquezas incautadas que su padre había asociado al fisco $^{611}$. En el año 633, el Concilio reunido en Toledo bajo mandato de Sisenando castigó a Suintila, a su esposa e hijos por sus crímenes que, según denunciaron los reunidos, consistieron en la apropiación de bienes. El rey depuesto y su familia fueron expulsados de la comunión, despojados de sus dignidades y sus bienes confiscados, excepto aquella parte que Sisenando, por su piedad, quiso dejarle. Geila, hermano de Suintila, por su infidelidad fue condenado a perder sus bienes y también sufrió la excomunión ${ }^{612}$. Chindasvinto hizo efectivos los castigos estipulados en sus leyes y en los Concilios que presidió. Estamos seguro de ello por las acciones posteriores de Recesvinto, a quien ya vimos aplicar una política rectificadora de las actividades de su padre ${ }^{613}$.

En el año 683, Ervigio perdonó a los implicados en la conjuración de Paulo que Wamba había sentenciado como traidores. La asamblea reunida en Toledo les restituyó el derecho de testificar, instó a que se borrara la mancha de su traición en su descendencia y resolvió que deberían ser ayudados con la entrega de bienes de la siguiente manera: se les

\footnotetext{
${ }^{608}$ Concilios, Toledo VII, año 646, c. I, p. 250.

${ }^{609}$ Idem.

${ }^{610}$ Ibidem, Toledo XVI, año 693, p 487.

${ }^{611}$ IsID. Hist. Goth., p. 264 y ss.

${ }^{612}$ Concilios, Toledo IV, año 633, p. 221.

${ }^{613}$ Ibidem, Toledo VIII, año 653, Decreto, p. 291.
} 
devolverían sus posesiones en la medida en que estas no hubieran sido entregadas en donación o estipendio a un tercero ${ }^{614}$. Años más tarde, Ervigio utilizó las confiscaciones también como arma política. En el Concilio de Toledo XV, Égica repudió la actitud de Ervigio de privar de los bienes y del honor a un grupo de aristócratas a los cuales había reducido a la servidumbre y los había sometido a violentos juicios ${ }^{615}$. Égica, también actuó como todos sus predecesores; la Crónica mozárabe de 754 recuerda que Witiza devolvió las tierras que su padre y antecesor al trono había confiscado ${ }^{616}$. Una noticia concreta del uso de las confiscaciones como mecanismo para eliminar a los enemigos políticos la encontramos en el XVI Concilio de Toledo. En el año 693, Égica condenó al exilio a Sisberto, obispo de la sede toledana, por el intento de asesinato contra él y toda su familia, y fue despojado de todos sus honores y de todos sus bienes ${ }^{617}$. Por último, nos llega un dato sobre las confiscaciones de la pluma de Valerio del Bierzo, quien relata el destino de una finca llamada Ebronanto que había pertenecido al ilustre Recimiro; la propiedad había sido arrasada y destruida por la ira del rey y los herederos de esta fueron castigados con el exilio ${ }^{618}$.

$\mathrm{El}$ análisis sobre los premios otorgados por los reyes a sus leales y las confiscaciones de bienes permite plantear una serie de conclusiones parciales. Para comenzar destacamos la participación de los fideles regis en aquellos Concilios en los cuales se promulgaron cánones relacionados con la defensa de los premios otorgados por el rey por la fidelidad prometida. Asimismo, en estos Concilios, en su mayoría, también se dispusieron cánones sobre la protección de la figura regia y su familia y, lo más interesante, sobre la restricción de alguna u otra forma del poder del rey. Entonces los grandes del reino no solo fueron testigos privilegiados en los Concilios, sino que fueron partícipes activos capaces de imponer sus intereses en las cláusulas canónicas. En el siguiente cuadro se observa de forma clara la concomitancia entre los cánones a los cuales referimos.

\section{Cuadro 1}

\footnotetext{
${ }^{614}$ Ibidem, Toledo XIII año 683, p. 426.

${ }^{615} \mathrm{Ibidem}$, Toledo XV, año 688, discurso, p. 451.

${ }^{616}$ Chronica muzarabica anni 754, p. 63.

${ }^{617}$ Concilios, Toledo XVI, año 693, canon IX, p. 509.

${ }^{618}$ VAL. Ord: p. 267. Por el contexto de la obra de Valerio, M.C Díaz y Díaz propone que fue Ervigio quien ordenó la confiscación y ruina de esa familia.
} 


\begin{tabular}{|c|c|c|c|c|}
\hline $\begin{array}{c}\text { Concilio de } \\
\text { Toledo }\end{array}$ & $\begin{array}{c}\text { Participación de } \\
\text { los fideles regis }\end{array}$ & $\begin{array}{c}\text { Cánones sobre los } \\
\text { premios o } \\
\text { confiscaciones }\end{array}$ & $\begin{array}{c}\text { Cánones limitantes } \\
\text { del poder regio }\end{array}$ & $\begin{array}{c}\text { Cánones de } \\
\text { protección } \\
\text { regia }\end{array}$ \\
\hline IV & Acta de apertura & Acta final & Acta final & Canon LXXV \\
\hline V & Acta de apertura & Canon VI & - & Cánones III, IV y V \\
\hline VI & Canon XIV & Cánones XVI, \\
XVII y XVIII
\end{tabular}

Este hilo conector existente entre los cánones sobre los bienes materiales, sobre la protección hacia los reyes y sus familias y sobre la limitación del poder está revelando que la relación entre la realeza y la aristocracia no se caracterizó por una horizontalidad absoluta como tampoco por una plena subordinación. La reciprocidad existente entre estos grupos de la clase dominante se evidencia en el hecho de que la entrega y defensa de los premios correspondientes por la fidelidad jurada tuvo como contradon la promesa de la protección de la realeza. Esta promesa les otorgaba a los reyes y a su familia una posición privilegiada y una inmunidad que coartaban la capacidad de actuar de los magnates ante un rey que se mostrase ineficaz. Por lo tanto, la aristocracia contrarrestó el poder del don intercambiado limitando el dominio regio a través de cánones. La clase dominante existía en un equilibrio inestable, la hegemonía política era disputada de forma constante por las distintas facciones aristocráticas que utilizaron los espacios de sociabilización pública para construir de forma permanente su poder político. Las contradicciones que surgen de las lecturas de los distintos 
Concilios, las marchas y contramarchas en las decisiones fueron solo aparentes, siendo en realidad reflejos de esta lucha por la supremacía política.

Asimismo, destacamos que lo confiscado a los traidores fueron en primer lugar las recompensas entregadas por la generosidad del rey, cuyo destino no fue engrosar el patrimonio del arca regia sino ser repartido entre los que habían mantenido la fidelidad, tal como la asamblea conciliar le indicó a Recesvinto. Los premios no se transmutaron en bienes privados ni hereditarios, pues los favorecidos debían perseverar en la fidelitas o no fallar en la misión encomendada para conservarlos.

La entrega de bienes fue la pieza clave de la construcción de la relación de fidelidad, el diálogo entre Wamba y Paulo desarrollado durante el juicio visto más arriba es una prueba concluyente. La aristocracia esperaba la entrega de honores, cargos y bienes a cambio de la promesa de su fidelidad, que se materializaba en grupos de guerreros dispuestos a luchar por el bando regio. En el Concilio de Toledo VIII, los asistentes (52 obispos, 14 abades, 11 vicarios de obispos y 18 miembros del oficio palatino ${ }^{619}$ ) saludan y bendicen al rey Recesvinto, de una forma reveladora para esta investigación:

“(...) ab exercituum Domino super serenissimum principem gloriossimum: gratiarum actio et reverentiae plenitudo a nobis omnibus in comune ipsi clementissimo principi bonorum gratifico largitori $(\ldots)^{m}$

La práctica de las confiscaciones de los bienes de los enemigos políticos fue llevada a cabo por casi todos los reyes, porque a la vez que anulaban a la competencia adquirían bienes que luego repartían para asegurar sus lealtades.

La lógica de distribuir los bienes adquiridos por las confiscaciones puede ser comprendida bajo los términos que había planteado Le Jan. En contextos de crisis política, los reyes sacrificaron las riquezas con el fin de legitimarse como buenos gobernantes y para asegurarse un elevado número de fideles regis. Ahora bien, esto se aplicaría para Le Jan a las situaciones de inestabilidad social, entendidas solo como momentos disruptivos. Por otro lado, la bibliografía reciente está planteando casi la inexistencia de crisis para el reino

\footnotetext{
${ }^{619}$ Concilios, Tol.VIII, rúbricas, p. 287-289.

${ }^{620}$ Ibidem, Toledo VIII, p. 286. El resaltado es propio.
} 
visigodo $^{621}$. Entonces, ¿cómo estas dos ideas pueden representar una misma realidad social? Creemos que el camino debería ser recuperar el concepto del marxismo clásico de crisis orgánica y el concepto de inestabilidad en el sentido weberiano.

El repaso de la documentación evidencia que los reyes debieron entregar dones para fortalecer los lazos políticos y de gobierno. Arrebataron los bienes de sus enemigos y se los ofrecieron a sus aliados, a sus fideles regis, a aquellos que disfrutaban de la cercanía del rey (Königsnähe). Al entregar los bienes confiscados los reyes se desprendían de las riquezas obtenidas, destruían una parte en un acto agonístico, en una ceremonia muy concurrida por la aristocracia, como fueron los Concilios. A través de la entrega de los bienes, los reyes se legitimaban ante una facción aristocrática y fortalecían su posición ganando lealtades que intentaron asegurar a través del juramento de fidelidad que se reguló a través de la vía legal.

Sin embargo, en una sociedad donde las riquezas eran difíciles de obtener por el bajo grado de explotación del campesinado, la redistribución de bienes fomentaba la competencia intra-aristocrática, la cual estimuló los conflictos por el poder del reino y por disfrutar de la cercanía del rey. La entrega de dones económicos y políticos a una facción aristocrática generaba una reciprocidad negativa sobre otra, y mientras que la primera facción se amalgamaba en torno al dominio regio, la segunda se volvía potencialmente disruptiva; unas veces el rey logró contenerlos, otras no. Entonces, la lógica de arrebatar/ofrecer en términos reciprocitarios fue el núcleo de la dinámica política de la aristocracia visigoda, que se encontraba en una crisis orgánica de dominación.

No hay duda de que la aristocracia aceptaba la condición superior del rey y hacía entrega de su fidelidad a cambio de un premio. No obstante, la relación asimétrica no situaba a aquella en posición de desventaja en relación con la realeza, pues tampoco esta relación brindó a los reyes elementos para construir una dominación permanente, ya que la fidelidad entregada era condicional, pudiendo romperse según las circunstancias políticas y en el caso de que alguna de las partes considerase que la otra fallaba en algún aspecto que se hubiesen prometido. Este aspecto fue un factor constituyente de la inestabilidad del sistema político. El quebrantamiento de los juramentos a pesar de constituir una ofensa grave resultó mucho más usual de lo que se suele suponer.

\footnotetext{
${ }^{621}$ PovedA ARIAS, P.: "Relectura de la supuesta crisis del fin del reino visigodo de Toledo, una aproximación al reinado de Égica a través de sus fuentes legales".
} 


\section{La fidelidad rota: rupturas en el ápice del poder}

El abandono del servicio al rey parece ser, a la luz de las fuentes eclesiásticas, un fenómeno bastante común. Valerio del Bierzo nos informa que para acudir a su lado su sobrino Juan tuvo que "reliquit seruitium regis" "multas idoneas ac nobiles personas, etiam ex palatio" que abandonaron el servicio del rey (seruitium regis relinquentes) para entrar al monasterio fundado por Fructuoso de Braga a mediados del siglo VII, convirtiéndose algunos de ellos en obispos ${ }^{623}$. Sin embargo, no siempre la disolución de los vínculos de fidelidad tomó la vía pacífica; al contrario, la mayoría de las noticias poseen un carácter violento. Por ejemplo, el gardingo Hildigisio rompió su fidelidad cuando conspiró junto con Paulo para perjudicar a su rey Wamba ${ }^{624}$.

El canon catorce del año 638 indicó que si algún fiel al rey faltase en su fídelidad o se mostrare inútil en aquello que le había sido confiado, su destino quedaría en manos del mismo rey. Los contemporáneos eran conscientes de que la fidelidad jurada podía romperse y que incluso esa traición se vería plasmada en un asesinato o en la participación en un complot, pues sentencian que

"Quod si post eius discessum quispiam reppertus fuerit eius vitae fuisse infidelis, quidquid largitate ipsius in rebus habuit conquisitis careat confiscandum et fidelibus largiendum" $" 625$.

Los mismos que alguna vez le juraron fidelidad al rey podrían convertirse en potenciales insidiosos, a pesar de que romper los vínculos de fidelidad podía generar consecuencias catastróficas para quienes lo hiciesen: la ruina económica, la pérdida del estatus y el destierro eran sus penas y la excomunión completaba el castigo. A pesar de las penas, hemos observado una y otra vez a los fideles regis quebrantar sus juramentos y desafiar a su líder. Esto último muestra que las expectativas (y las posibilidades) de éxito de

\footnotetext{
${ }^{622}$ VAL. Replic., p. 304.

${ }^{623}$ Vit. Fruct, p. 90.

${ }^{624}$ IUL. TOL. $H W$, p. 222.

${ }^{625}$ Concilios, Toledo VI, año 638, c. XIV, p. 242.
} 
una rebelión estaban siempre abiertas debido a la inestabilidad recurrente del sistema de poder.

Cuenta Isidoro que los gothi decidieron asesinar a Agila (549-554), elegido cinco años antes (rex creatur $^{626}$ ), al ver devastado el ejército enviado contra el rebelde Atanagildo, a quien inmediatamente le entregaron el gobierno ${ }^{627}$. Witerico fue brutalmente asesinado por miembros de su propio círculo, aparentemente durante un convite ${ }^{628}$; la misma suerte tuvo Sisebuto que, según las noticias, murió envenenado ${ }^{629}$, mientras que Wamba había sido inducido a un estado de inconsciencia involuntaria. Tulga sufrió la ablación de una de sus manos. La espada y el veneno fueron las armas más elegidas por aquellos fideles que cometían el acto de traición y así lo expresó Égica en su ley 2, 5, 19:

“ (...) Quod et temporibus nostris in quibusdam detectum manifestis eorum confessionibus retinetur qui nostram gloriam conati sunt aut gladio interimere aut mortifera ueneni potione decipere" ${ }^{630}$

Miembros de la familia regia (por antonomasia fideles regis) también actuaron contra sus reyes. Hermenegildo se enfrentó a su padre Leovigildo en una rebelión abierta; Suintila fue víctima de la traición de su hermano Geila; y Égica tuvo que enfrentar a la reina viuda, madre de su esposa, y a otros miembros de su familia política.

Las rupturas de los vínculos de fidelidad hacia el rey no solo fueron perpetradas por los miembros de la alta aristocracia. Estos junto a los hombres libres también abandonaban a sus reyes, teniendo lugar estas rupturas en los enfrentamientos militares, es decir, en plena acción.

Los reyes visigodos marcharon a la guerra tantas veces como les había sido posible: contra los extranjeros (francos, bizantinos), contra los pueblos no tutelados por los visigodos (vasco, cántabros, astures) y contra otros poderosos por el control de la corona ${ }^{631}$. Durante estos últimos enfrentamientos perder el favor de las tropas era una posibilidad real, peligro

\footnotetext{
${ }^{626}$ Ver nota dos e ISID. Hist. Goth., p. 246.

${ }^{627}$ Ibidem., p. 249.

${ }^{628}$ Ibidem, p. 271.

${ }^{629}$ Ibidem, p. 274.

${ }^{630} L V$, p. 358 y 359.

${ }^{631}$ Ver capítulo 3.
} 
que se concretó más de una vez. Los jefes de las clientelas acudían al llamado del rey para enfrentarse a los enemigos internos; pero no siempre lo acompañaron hasta el final. Suintila (621-631) sufrió el abandono de sus tropas en el campo de batalla y "omnis Gothorum exercitus se ditioni Sisenandi subegit" ${ }^{\prime 632}$. En la batalla contra Muza el ejército que dirigía Rodrigo se dio a la fuga, y luego un sector de la aristocracia goda negoció pactos con los invasores árabes ${ }^{633}$. Muchos de los destronamientos exitosos se lograron per tumultuosas plebes, por la participación de los rusticarum plebium seditioso tumultu ${ }^{634}$; esto nos indica que las conjuras contra los reyes fueron perpetradas por una facción de la aristocracia y sus tropas satélites, las cuales a veces pertenecieron originalmente a la partida regia. El caso del cambio de lealtad de las tropas bajo el mando del duque Paulo es el mejor documentado, ejemplo que trabajaremos en profundidad en el próximo capítulo cuando examinemos el rol de los grandes del reino en el ordenamiento del ejército. Por lo expuesto, podemos afirmar que cada vez que uno de los grandes rompía con su rey, su propio séquito y los grupos de guerreros que lo secundaban lo acompañaban en la sedición.

La observación de los datos examinados a lo largo de esta investigación concuerda más con una fragmentación de la lealtad que con una fidelidad absoluta al ápice del poder; la aristocracia abandonaba sus vínculos de fidelidad para con el rey en busca de mayores beneficios políticos y económicos. Esta situación sociopolítica descripta se correspondió con el fenómeno del localismo observado en el capítulo tres y tuvo una estrecha relación con la autonomía de acción militar de la aristocracia.

\footnotetext{
${ }^{632}$ FREDEEG. Chron., Libro IV, Cap. 73.

${ }^{633}$ Ver MARTIN, C.: La géographie du pouvoir dans l'Espagne visigothique, p. 130.

${ }^{634}$ Así nos los indica Recesvinto en el Concilio de Toledo VIII del año 653. Concilios, p. 283. Sobre el término "rústico" ver el próximo capítulo.
} 


\section{Capítulo 6}

\section{ARISTÓCRATAS Y GUERREROS: ASPECTOS DE SU RELACIÓN}

En este capítulo estudiaremos el ejército visigodo del reino de Toledo. En primer lugar, realizaremos un balance historiográfico con el fin de alcanzar una mejor comprensión sobre el problema planteado.

En la segunda parte del capítulo, analizaremos la organización y composición social del ejército, así como las relaciones clientelares dentro del marco de este, los vínculos de dependencia, los distintos grados de sujeción política y la entrega de premios. El análisis de este conjunto de aspectos aportará elementos para entender la naturaleza del ejército visigodo y el desarrollo e importancia de las relaciones políticas mediadas por las recompensas. Llegados a este punto de la investigación, comprenderemos que el número de armas listas para entrar en batalla se traducía en la fuerza de los líderes aristocráticos (incluido el rey) para actuar en la arena política del reino. Asegurar la lealtad de los hombres en las guerras, 
en las batallas por el poder o por su protección personal significaba construir, mantener y aumentar la posición alcanzada. La disputa por la hegemonía política muchas veces tuvo su lugar en la convocatoria de las tropas, y el cuestionamiento de la dominación legítima regia se concretó en el campo de batalla.

\section{1}

\section{Análisis de la producción historiográfica sobre el ejército visigodo de Toledo}

Los historiadores abordan el problema del ejército visigodo desde diferentes perspectivas. Las pocas fuentes disponibles hasta el momento ${ }^{635}$ (un conjunto de leyes, datos sueltos en crónicas y hagiografías, testimonios epigráficos y algunos cánones conciliares) dificultan el consenso entre los especialistas, sobre todo al momento de definir el carácter y composición del cuerpo militar. Además, las líneas de investigación abiertas y sus conclusiones sobre los mismos documentos estudiados se orientan de acuerdo con el marco interpretativo elegido, pues se acuerda que existe una correspondencia entre la forma que adquiere el ejército y la sociedad. Desde la escuela institucionalista hasta las corrientes apoyadas en la literatura antropológica se ocupan del ejército visigodo, aunque no es un tema de trabajo específico desde la monografía de Sánchez Pérez de $1989^{636}$ (a pesar del renovado interés por la temprana Edad Media). Solo es tratado como elemento subsidiario de análisis $^{637}$, en manuales ${ }^{638}$, en estudios sobre la guerra en Europa durante la temprana Edad

\footnotetext{
${ }^{635}$ Petersen, L.: Siege warfare and military organization in the successor states (400-800). Byzantium, the West and Islam, (History of warfare; volume 91), Leiden-Boston: Brill, 2013, p. 165.

${ }^{636} \mathrm{El}$ fichaje bibliográfico realizado por A. Ferrerio es una herramienta esencial para realizar dicha afirmación. FERrEIRO, A.: The Visigoths in Gaul and Spain (a.D. 418- 711). A bibliography, Leiden: Brill, 1988. FERREIRO, A.: The Visigoths in Gaul and Iberia. A Supplemental Bibliography, 1984-2003. The Visigoths in Gaul and Iberia (Update). A Supplemental Bibliography, 2004-2006, (The Medieval and Early Modern Iberian World, 28 y 35), Leiden: Brill, 2006. FerreIro, A.: The Visigoths in Gaul and Iberia (Update). A Supplemental Bibliography, 2007-2009, Leiden: Brill, 2011. FerreIro, A.: The Visigoths in Gaul and Iberia (Update). A Supplemental Bibliography, 2010-2011, Leiden: Brill, 2014.

${ }^{637}$ DíAZ MARTíneZ, P.: "La dinámica del poder y la defensa del territorio: para una comprensión del fin del reino visigodo de Toledo", pp. 167-205.

${ }^{638}$ DíAz MARTíneZ, P.: Hispania tardoantigua y visigoda. Madrid: Istmo, 2007. LORING, Ma. I., PÉREZ, S. Y FUENTES, P.: La Hispania tardorromana y visigoda ...
} 
Media $^{639}$, en estudios de alcance general ${ }^{640}$, y más recientemente en un libro que vincula las sociedades con el ejército en la Península Ibérica entre los siglos VII al XI ${ }^{641}$.

A continuación, repasaremos los autores más influyentes y sus argumentos en torno al problema enunciado. Cada escuela realiza aportes significativos (sobre todo en lo relativo al estudio filológico y contextual de las leyes militares) que no pueden ser desechados sin miramientos en las investigaciones empíricas actuales. Asimismo, existen presupuestos historiográficos cuyos argumentos son adoptados por las sucesivas generaciones de investigadores sin reflexión crítica.

En la década del '20, Torres López dio a luz a un extenso artículo cuya finalidad fue demostrar la existencia de un estado visigótico sustentado en el derecho público sin absorción del poder político por parte de particulares. Según su propuesta, el principio de utilidad pública se materializaba, por ejemplo, en la convocatoria del ejército realizada por el rey para la defensa del reino ${ }^{642}$. Su concepción política del estado tiene como base "la no existencia de la personalidad del poder" ${ }^{443}$ y "el vigor del concepto del derecho" ${ }^{\circ 44}$. En este marco interpretativo realiza el estudio de los términos leudes y fideles. La exégesis de la ley 4, 5, 5 le indica que el vocablo leudes designaba a todos los súbditos en general que participaban de la guerra. Comparando los numerosos pasajes legislativos sostiene que el término fideles $^{645}$ es sinónimo de súbdito leal, no de vasallo del rey. Negó la existencia de "una especial relación del rey con algunos súbditos ligados por fidelidad especial” ${ }^{346}$. Sánchez Albornoz contesta punto por punto los planteos de Torres López, desarrollando su propia teoría sobre la cuestión, logrando imponer su visión de la sociedad goda hasta la aparición de los estudios de Barbero y Vigil en la década de 1970.

\footnotetext{
${ }^{639}$ HALsAll, G.: Warfare and society in the Barbarian West, 450-900; PETERSEN, L.: Siege warfare and military organization in the successor states (400-800) ...

${ }^{640}$ Wickham, C.: Una historia nueva de la Alta Edad Media.... Wickham, C.: El legado de Roma. Una historia de Europa de 400 al 1000, Barcelona: Ed. Pasado y Presente, 2013.

${ }^{641}$ ISLA FREZ, A.: Ejército, sociedad y política en la Península Ibérica entre los siglos VII y XI. Madrid: CSIC, 2010.

${ }^{642}$ Ver supra capítulo 1 las formulaciones de este autor sobre el concepto de estado visigodo y su marco de referencia historiográfico.

${ }^{643}$ TORRES LÓPEZ, M.: “El estado visigótico" ..., p. 375.

${ }^{644}$ Ibidem, p. 375.

${ }^{645}$ Utiliza las leyes: $6,1,6 ; 3,5,3 ; 9,2,9 ; 2,5,19 ; 9,2,8 ; 12,1,2$. Ibidem, p. 430 y ss.

${ }^{646}$ Ibidem, p.439.
} 
Sánchez Albornoz propone que la sociedad visigoda fue una sociedad protofeudal $^{647}$; el estudio del ordenamiento del ejército fue central en su argumentación. Los visigodos introdujeron el deber y el derecho de todos los hombres libres y aptos de concurrir a la guerra $^{648}$, aunque la incorporación de los provinciales romanos a las filas militares fue algo posterior, imposible de fechar por la parquedad de las fuentes ${ }^{649}$. Dedica varias páginas al problema del aprovisionamiento de las armas, no solo por estar preocupado por los tipos de pertrechos, sino porque su distribución la relacionó con la perpetuación de la organización militar germánica en el reino de Toledo que vinculaba la libertad de los hombres con la posesión de armas. El examen de las leyes 9, 2, 1-6 le permite afirmar la existencia de una organización de tipo decimal ${ }^{650}$ heredada de los tiempos romanos; los potenciales hombres en armas se encontraban encuadrados en thiufas, centenas y decanías, conformando un conjunto anterior a la reunión del ejército convocada por el rey ${ }^{651}$. Considera de suma importancia la división del ejército en caballería e infantería, pues de seguro los fideles y gardingos y otros miembros de la nobleza combatieron a caballo. Aquí llegamos al punto substancial de su planteo. Afirma que aquellos que mantuvieron un vínculo personal con el rey y cumplieron un deber militar superior al resto de los hombres libres recibían tierras con el fin de mantener sus unidades de caballería especializadas para entrar en la guerra, y aquí es donde encuentra el origen de la protofeudalización del ejército, haciéndose eco de las teorías de Brunner y $\operatorname{Dospch}^{652}$. Para sostener lo dicho, analiza el pasaje de la Vita

\footnotetext{
${ }^{647}$ Ver supra capítulo 1

${ }^{648}$ SÁNCHEZ ALBORNOZ, C.: "El ejército visigodo: su protofeudalización", Investigaciones y documentos sobre las instituciones hispana, Edit. Jurídica de Chile, Santiago, 1970, pp. 5-56.

${ }^{649}$ SÁNCHEZ AlBORNOZ, C. "El ejército visigodo: su protofeudalización” ..., p. 10. Torres López sostuvo que desde los tiempos de Eurico los hispanorromanos se incorporaron al ejército godo. Ver: TORRES LÓPEZ, M.: Lecciones de historia del Derecho. Salamanca, 1934, p.23. ORLANDIS, J.: Historia del reino visigodo español... p. 168. Thompson consideró que los romanos siempre se sintieron diferentes. THOMPSON, E. A: The goths in Spain... p. 146. Por su parte King creyó probable que después de la unificación religiosa los romanos eran incorporados al ejército, pero es difícil decir con exactitud desde qué fecha. KING, P.D.: Derecho y sociedad en el reino visigodo..., p. 92.

${ }^{650}$ Idea aceptada por KING, P.D.: Derecho y sociedad en el reino visigodo..., p. 93, ORLANDIS, J.: Historia del reino visigodo español..., p. 169 y 170. MARTIN, C.: La géographie du pouvoir dans l'Espagne visigothique, p. 153.

${ }^{651}$ SÁNCHEZ ALBORNOZ, C.: "El ejército visigodo: su protofeudalización”, p. 26 y ss.

${ }^{652}$ Dopsch, A.: Fundamentos económicos y sociales de la cultura europea (de César a Carlomagno). México: Fondo de Cultura Económica, 1986, pp. 385 y ss. Barbero y Vigil ya señalaron la fuerte influencia del austríaco sobre Sánchez Albornoz. Estos autores criticaron fuertemente tanto a Dopsch como al abulense al señalar:
} 
Fructuosi $^{653}$ en el cual se describe el pedido que realizó el cuñado de Fructuoso al rey de una parte de las heredades del monasterio de Compluto que el santo presidía, para que le sea concedido a él quasi pro exercenda publica expeditione conferretur ${ }^{654}$. Defiende la hipótesis de que el duque familiar de Fructuoso no peticionó la entrega de la propiedad a fín de realizar una sola expedición (pues por la prescripción de las leyes estaba obligado a acudir siempre), sino para prestar una asistencia especial; solicitó un beneficio militar para servir como caballería en la guerra. Para este autor, no es una sorpresa que se hayan generalizado las figuras jurídicas de las concesiones de tierra causa stipendi por servir a caballo ${ }^{655}$. Con relación a esto, constata la participación de un número significativo de siervos en las batallas recién para mediados del siglo VII (como lo dispone la ley de Ervigio 9, 2, 9), fenómeno que tuvo su origen en el acrecentamiento del poder de la nobleza debido a su arraigo a la tierra consecuencia de la entrega de beneficios militares realizados por los reyes ${ }^{656}$. Sánchez Albornoz específica que

"las viejas ideas del ejército popular germánico habían dado paso a una fuerza armada constituida, en parte, por masas en relación de dependencia personal con los miembros de los clanes que integraban las más elevadas estructuras sociales del reino"657.

\footnotetext{
"Dopsch y Sánchez Albornoz adolecen de los mismos defectos metodológicos que Brunner, al admitir que la génesis del feudalismo depende en concreto de un hecho militar tan problemático como es la divulgación de la forma de guerrear a caballo", BARBERO, A. \& VIGIL, M: La formación del feudalismo en la Península Ibérica..., p. 160.

${ }^{653}$ Vit. Fruct, p. 84.

${ }^{654}$ En torno a los orígenes del feudalismo I, pp. 168-173. Manuel Torres López entendió este pasaje de manera diferente, consideraba que la cesión de tierras para el mantenimiento del ejército poseía un interés de utilidad pública. TORRES LÓPEZ, M.: "El estado visigótico".

${ }^{655}$ SÁNCHEZ AlBORNOZ, C.: "El ejército visigodo: su protofeudalización", p. 42.

${ }^{656}$. Declaró: "Sólo más tarde, tal vez en las postrimerías de la historia hispanogoda, al arraigar en la tierra los potentes visigodos e incorporarse al ejército los romanos poderosos y al aumentar la población servil del reino, fue preciso decretar la obligación de todos los dueños de siervos de acudir a campaña con una parte de los suyos y no inermes sino bien armados. Pero esos decretos como otros procesos históricos sincrónicos, fueron, sobre todo, consecuencia de lo que podríamos llamar protofeudalización del Estado y, por ende, del ejército hispanovisigodo". Ibidem, p. 30. Thompson y Arce consideran que el ejército godo del reino tuvo un fuerte componente servil. THOMPSON, E. A.: The goths in Spain... p. 262. ARCE, J.: Esperando a los árabes: los visigodos en Hispania (507-711) ..., p.127.

${ }^{657}$ Ibidem, p. 38.
} 
Los planteos de Sánchez Albornoz son recogidos por los académicos ${ }^{658}$; ejemplo de esto es el libro de King (aunque con alguna distancia: por ejemplo, la interpretación de la ley sobre leudes ${ }^{659}$ ). Este autor - muy citado entre los visigotistas que comulgan con la tesis que califica a la monarquía visigoda como teocrática - entiende que las obligaciones militares contraídas por los nobles para con el rey (consecuencia de sus vínculos de fidelidad) debieron ser muy costosas, justificando plenamente la concesión de tierras ${ }^{660}$. Argumenta que el control de las tropas fue una prerrogativa del rey, que reunía y disolvía al ejército, comandaba personalmente o delegaba su mando a un tercero. Estudiando la ley de administración militar 9, 2, 6, observa la existencia de un ejército permanente en complejos de castra, aunque no le resultó posible la existencia de una guarnición en cada una de las ciudades. El aprovisionamiento de este ejército estaba a cargo de un annonarius (ley 9, 2,6) y bajo órdenes del dux exercitus provinciae y, en una escala inferior, del tiuphadus. Sin embargo, sostiene que los fideles regis y los gardingi no se encontraban bajo las órdenes de los oficiales; estos magnates mandaban a sus propios seguidores en las batallas, los bucellarii y saiones ${ }^{661}$.

Tanto Sánchez Albornoz como King utilizan el cuerpo legislativo como principal fuente de investigación, lo cual los lleva a admitir la imposibilidad de realizar de forma más acabada un estudio más completo. En ambos casos el enfoque historiográfico limita los problemas a plantearse.

Desde otra perspectiva, Barbero y Vigil en sus estudios consideran que en el reino visigodo de Toledo las relaciones de dependencia y subordinación del campesinado marcaron el ritmo social, las cuales se expresaron en las instituciones políticas, jurídicas y en el sistema ideológico ${ }^{662}$. En contra de la historiografía jurídica-institucional, rechazan la idea de identificar la protofeudalización del reino visigodo con la organización militar, pues plantean que el ejército reprodujo las características principales de la sociedad. Constatan la existencia formal de un ejército público, aunque su composición social varió de una época a otra. Ven

\footnotetext{
${ }^{658}$ Orlandis sigue los argumentos del abulense. ORLANDIS, J.: Historia del reino visigodo español..., p. 168 y SS.

${ }^{659}$ KING, P.D: Derecho y sociedad en el reino visigodo..., p. 77, n. 29.

${ }^{660}$ Ibidem, p. 92 y ss.

${ }^{661}$ Ibidem, p. 95. Sobre los bucelarios en la Antigüedad Tardía ver: RUCHESI, F. "Los bucellarii y el Imperio Romano: sus orígenes, empleo y la cuestión de la cohesión social de sus componentes", Studia Historica. Historia Antigua, 34, 2016, 167-188.

662 BARbero A. Y Vigil, M.: La formación del feudalismo en la Península Ibérica ..., p. 41.
} 
que la sujeción de los campesinos a la tierra, que se extendió de forma dominante, perjudicó seriamente las finanzas estatales y sus posibilidades de mantener un ejército público, a la vez que alimentó a los ejércitos privados de los grandes propietarios. Por lo tanto, en el siglo VII fueron los ejércitos privados los convocados a cumplir las funciones públicas ${ }^{663}$. Las filas militares estaban compuestas tanto por hombres libres como por siervos. Observan que el campesinado cumplía con el servicio militar como

"una prestación personal más que debía al señor, poniéndose de relieve así su analogía con las prestaciones de trabajo y la forma de uso de la tierra dentro de un marco general de obligaciones personales de dependencia" ${ }^{664}$.

Por otra parte, las obligaciones militares de la nobleza para con el rey son entendidas como "prestaciones políticas" 665 encuadradas en el régimen general de fidelidad.

Una vez puestos en tensión los argumentos de Sánchez Albornoz por Barbero y Vigil, la historiografía discute durante las últimas dos décadas del siglo XX sobre la naturaleza feudal o protofeudal de la sociedad visigoda y, por lo tanto, del ejército. Los historiadores contemporáneos se adscriben de forma general a una u otra matriz explicativa. Por ejemplo, García Moreno señala que para mediados del siglo VII las fuerzas militares del reino estaban constituidas por clientelas privadas bajo mando directo de un reducido número de nobles laico y eclesiásticos ${ }^{666}$, situación que respondería al avanzado estado de feudalización de los lazos de dependencia. Con raras excepciones, en la bibliografía de origen español la corriente historiográfica fundada por Barbero y Vigil sigue imponiéndose, encerrando en la tesis de un feudalismo visigodo a muchos de los especialistas.

Pérez Sánchez en un exhaustivo trabajo sobre el ejército visigodo analiza la evolución de la organización militar goda desde el siglo IV hasta el VII, estableciendo una correspondencia entre el carácter del ejército y la organización social ${ }^{667}$. Advierte que en el siglo VI existió un ejército regular con organización decimal y profesional ${ }^{668}$, en convivencia

\footnotetext{
${ }^{663}$ Ibidem, p. 44.

${ }^{664}$ Ibidem, p. 52.

${ }^{665}$ Idem.

${ }^{666}$ GARCíA Moreno, L. A.: Historia de España visigoda..., p.177 y ss.

${ }^{667}$ PÉREZ SÁNCHEZ, D.: El ejército en la sociedad visigoda.

${ }^{668}$ Ibidem, p. 117.
} 
con bandas armadas dependientes de los grandes propietarios que cumplían funciones públicas. Para el siglo VII, ambos tipos de ejércitos coexistían, pero las tropas privadas ganaron la primacía llegando a absorber al ejército público ${ }^{669}$. Finalmente, el autor defiende que el ejército visigodo (al mando del rey o un magnate) fue el resultado de la suma de las tropas compuestas por los dependientes de los nobles. Estas tropas pudieron cumplir indistintamente el servicio público como las tareas pedidas por su señor, inclusive si esto incluía enfrentar al mismo rey ${ }^{670}$. En conclusión, para este autor la organización militar del siglo VII no fue más que el reflejo del sistema feudal, de la atomización sociopolítica del reino godo.

Como podemos observar, Pérez Sánchez sigue la tesis del feudalismo visigodo propuesta por Barbero y Vigil; aceptando la dependencia extendida reconoce que la masa de soldados — a pesar de la heterogeneidad de las condiciones jurídicas - fue dependiente de algún noble terrateniente.

Otra historiadora que se enfila detrás de la tesis del feudalismo visigodo es Valverde Castro. Su análisis sobre el ejercicio del poder regio visigodo se centra en sus elementos teóricos y simbólicos y en sus limitaciones prácticas. Argumenta que los reyes mantuvieron el carácter guerrero, lo cual se manifestó en el reconocimiento como jefe supremo del ejército $^{671}$. La teoría política-religiosa legitimaba las atribuciones militares regias. Un elemento de análisis interesante que destaca la autora (ya detectado por Orlandis, pero sin desarrollar ${ }^{672}$ ) fue la plasmación simbólica de la supremacía militar del rey. También subraya que se conservó la concepción pública del ejército, aunque la capacidad de ordenar del rey estaba limitada por la imposibilidad real de hacer cumplir a los nobles con las obligaciones militares que las leyes indicaban, lo que se traduciría en la desaparición del carácter público del ejército, todo en un “( ...) claro proceso de feudalización (...)”673.

\footnotetext{
${ }^{669}$ Ibidem, pp. 129 y ss.

${ }^{670}$ Ibidem, p. 136.

${ }^{671}$ VAlVERde CASTRO, Ma. R.: Ideología, simbolismo y ejercicio del poder real en la monarquía visigoda: un proceso de cambio..., pp. 233-236.

${ }^{672}$ ORLANDIS, J.: Historia del reino visigodo español..., p. 167. Este autor detectó que la imagen del reycaudillo dejó su marca en la liturgia hispana. Ver capítulo 7.

${ }^{673}$ VALVERDE CASTRO, Ma. R.: Ideología, simbolismo y ejercicio del poder real en la monarquía visigoda: un proceso de cambio, p. 236.
} 
Por su parte, en una línea historiográfica similar a la vista, Castellanos defiende que lo más importante de las leyes militares del siglo VII fue que reflejan la desesperación de los reyes por asegurarse la ayuda de la aristocracia en el engrosamiento del ejército ${ }^{674}$.

Recientemente, Díaz Martínez describe al ejército visigodo de fines del siglo VII como un ejército formado en su amplia mayoría por milicias rurales poco entrenadas, dependientes de los grandes propietarios, y por cuerpos armados profesionales, vinculados a los gardingos y a la aristocracia del palacio; se sumaban a estos últimos las tropas de elite bajo el comando del comes spathariorum ${ }^{675}$.

Isla Frez, en el mismo carril argumentativo que Díaz Martínez, precisa que las huestes, conformadas en gran medida por los propietarios y sus guerreros, guardaron un vínculo personal con los duces y comes, antes que un nexo de fidelidad con el rey ${ }^{676}$.

En opinión de Salrach, los ejércitos de los reinos romano-germánicos se compusieron "por un sólo ejército público, a las órdenes de un poder único, el rey, que para su funcionamiento puede utilizar canales privados"677. C. Martin, con una posición historiográfica "continuista", se manifiesta a favor del carácter público del ejército y de la delegación del dominio regio en agentes territoriales de la monarquía ${ }^{678}$, incluyendo el mando militar. Según su marco interpretativo general, esta delegación no significó que el poder regio estatal se dividiera o pulverizara, todo lo contrario, en esos agentes se multiplicaba haciendo al estado más fuerte ${ }^{679}$.

Como ya hemos señalado en los primeros capítulos, la historiografía analiza al periodo de nuestro interés desde puntos de vista nuevos. Esta corriente renovadora impulsa estudios sobre la guerra y la organización de los ejércitos de los estados sucesores del Imperio Romano. A continuación, nos ocuparemos sobre algunos autores que tratan el problema de

${ }^{674}$ CASTellanos, S.: Los godos y la cruz... p. 330

${ }^{675}$ DíAZ, P.: "La dinámica del poder y la defensa del territorio: para una comprensión del fin del reino visigodo de Toledo", p.189.

${ }^{676}$ IsLA FreZ, A.: Ejército, sociedad y política en la Península Ibérica entre los siglos VII y XI, p. 84.

${ }^{677}$ SALRACH, J. M.: "Del estado romano a los reinos germánicos: en torno a las bases materiales del poder del estado en la antigüedad tardía y la Alta Edad Media", De la antigüedad al Medievo: siglos IV-VIII, 1993, pp .95-142, p 128-129.

${ }^{678}$ MARTIN, C.: La géographie du pouvoir dans l'Espagne visigothique, p.151-203 (en especial p. 176-180).

${ }^{679}$ Ver en el capítulo 1 las críticas hechas a esta autora. 
la guerra desde diferentes ángulos y con perspectivas historiográficas renovadas ${ }^{680}$ (a excepción del caso visigodo).

Hace ya más de una década, en un estudio notable Halsall desarrolla la relación entre la guerra y la sociedad en Europa occidental entre los años 500 y $900^{681}$; a pesar de su carácter general, los argumentos expuestos son interesantes para pensar el funcionamiento del ejército visigodo. En su opinión, a lo largo del siglo VI y en las primeras décadas del VII la naturaleza del ejército en los territorios post romanos experimentó una serie de transformaciones al ritmo del desarrollo socioeconómico. En un primer momento, los jefes bárbaros se convirtieron en reyes de sus pueblos, generales de los ejércitos otrora romanos, se asentaron sobre las tierras y consolidaron sus posiciones con su reparto. La identidad étnica bárbara subsumió a todo lo considerado romano, convirtiéndose en un factor tan determinante que los romanos debieron pagar los impuestos y los bárbaros ir a la guerra. En el tardío siglo VI, fue cada vez más común la asociación del estatus de libre con la identidad étnica y, lentamente, como consecuencia de los cambios sociales (la aristocracia se fue fortaleciendo afianzando su posición sobre la tierra y sobre el resto de la población que comenzó a caer bajo su dependencia) los ejércitos compuestos de guerreros identificados con una etnia particular descendientes de las tropas de campaña tardorromanos trasmutaron en ejércitos organizados e integrados por poseedores de tierras ${ }^{682}$.

Halsall concluye que las instituciones militares que sobrevivieron a la caída del sistema romano (en el caso visigodo la división decimal, la oficina encargada de la leva militar) fueron transformándose hasta tal punto que hacia el 700 el ejército regular pago dejó de existir. Si bien continuó la disposición que señalaba que los hombres libres tenían la obligación de hacer la guerra, en la práctica el ejército estuvo compuesto por fuertes terratenientes y sus dependientes. Esta aristocracia de cultura militar retuvo títulos en teoría por el servicio regio. Esta legitimación del poder aristocrático por parte del rey fue un cambio fundamental. A comienzos del siglo VIII, la aristocracia ordenaba a los guerreros, con los cuales mantenía una relación de dependencia.

\footnotetext{
${ }^{680}$ Por ejemplo: PETERSEn, L. Siege warfare and military organization in the successor states (400-800) ...; SMITH, K, A.: War and the Making of Medieval Monastic Culture, Suffolk: The Boydell Press, 2013.

${ }^{681}$ HALSALL, G.; Warfare and society in the Barbarian West, 450-900

${ }^{682}$ HALSALL, G.; Warfare and society in the Barbarian West, 450-900, pp. 40-70.
} 
En el caso puntual de la organización del ejército visigodo, Halsall cuestiona la existencia de un ejército permanente para el siglo VII, más bien considera que la ley que dispuso sobre el almacenamiento de los víveres para los ejércitos $(9,2,6)$ hizo referencia al suministro de las tropas de paso por las ciudades o castella. Como King ${ }^{683}$, opina que en cada complejo de castra y fortalezas no existiría una guarnición de tropas permanente por su alto costo del abastecimiento, aunque sí cree en la permanencia de tropas disponibles para la salvaguarda del rey y los oficiales, pero estos no componían elementos suficientes para ser llamados ejército. Las leyes militares promulgadas por Wamba y Ervigio lo impulsan a sostener que el servicio militar constituía una obligación de todos los hombres; no obstante, le resulta poco probable que las leyes reflejasen una realidad social, y más bien propone que las respectivas leyes, sobre todo la de Ervigio, operaron sobre "a chain of lordship and clientship " ${ }^{684}$. Arriba a esta conclusión analizando el contexto legislativo y político visigodo: en referencia a lo primero, según él, la preocupación por ordenar las relaciones entre patrones y patrocinados fue constante; y en cuanto al segundo aspecto, las turbulencias alrededor del trono promovieron una legislación para obligar a la aristocracia a cumplir sus deberes militares. Afirma que la base de organización del ejército godo fueron los séquitos aristocráticos, esto le revela similitudes con las zonas del norte de los Pirineos.

En los marcos de las observaciones anteriores, Halsall señala que la evolución de un ejército regular a uno compuesto por los dependientes de la aristocracia en Hispania fue similar, si no igual, a las transformaciones experimentadas por los francos; la comparación le permite sostener que esta metamorfosis en lo militar no implicó automáticamente un debilitamiento del dominio regio ${ }^{685}$. Sin embargo, sugiere que los reyes visigodos no tuvieron la fuerza suficiente para penetrar en las sociedades locales - a pesar de los esfuerzos por mantener la unidad del reino desde lo político e ideológico - con el fin de crear una situación en la cual la preeminencia social dependiese en gran medida de los favores regios.

El aporte más significativo de Halsall, a nuestro entender, es su caracterización sobre la relación entre los guerreros y la aristocracia. Señala correctamente que existió una cadena de mando "vertical" entre estos dos sujetos sociales que debe ser entendida como una relación

\footnotetext{
${ }^{683}$ KING, P.D.: Derecho y sociedad en el reino visigodo..., p. 92.

${ }^{684}$ HalsalL, G.: Warfare and society in the Barbarian West, 450-900, p. 61

${ }^{685}$ Ibidem, p. 63
} 
social laxa, que podría involucrar donaciones de tierras y promesas de lealtad, pero sin contenido de formalidad alguna, y menos de legalidad. Estas redes eran personales y muy a menudo informales; las recompensas entregadas podrían ser bienes muebles o intangibles, como el apoyo en disputas o en casos legales ${ }^{686}$.

Por su parte, Wickham sostiene argumentos similares a los expuestos más arriba. Su análisis muestra que en el reino de Toledo el ejército romano asalariado desapareció dando paso a un ejército "basado en la obligación pública de ingresar en sus filas"687. Siguiendo las leyes que hacen referencia a los clientes, constata que los magnates tuvieron a su cargo soldados que recibían tierras a cambio de sus servicios; estos no integraban ningún ejército regular bajo las órdenes de un duque, conde o patronus ${ }^{688}$

Llegados a este punto, es evidente, entonces, que los ejes dicotómicos centrales que discuten los especialistas son: si existió un único cuerpo militar godo permanente de carácter público o uno integrado por tropas aportadas por la aristocracia de forma temporal y privada (por lo tanto, si la estructura era decimal o territorial, la importancia y el número de los guerreros a caballo); si la convocatoria a las filas militares concernía solamente a los hombres libres de estirpe visigoda o también a los provinciales romanos $\mathrm{y}$, de aceptar esto último, de cuándo data la integración; y si la forma de pago se efectuaba bajo el antiguo sistema imperial de la annona o si el rey entregaba concesiones de tierras y bienes - sobre esto último se discute fuertemente el carácter pleno o beneficial de aquellas-. Las fuentes sobre el ejército, principalmente las leyes civiles, fueron el centro de estos debates. Para los autores descubrir el carácter pleno o beneficial de las concesiones de tierras o bienes entregados por el rey a la aristocracia como retribución por participar en asuntos de gobierno y en la guerra es la clave que descifraría el problema presentado.

Algunos problemas historiográficos, como la data de la incorporación de los romanos al ejército godo, perdieron su lugar principal frente a otro que es el eje de las discusiones dadas en los últimos años. Esto es los debates en torno al pago de los soldados: si se concretaba con lo recaudado por los impuestos o a través de la entrega de tierras. Como

\footnotetext{
${ }^{686}$ Ibidem, p.56.

${ }^{687}$ WICKCHAM, C.: Una historia nueva de la alta edad media..., p. 168.

${ }^{688}$ Idem.
} 
demostramos, este aspecto es central para pensar de una u otra manera la caracterización general del periodo temprano medieval.

A la luz de los exámenes realizados, estamos en condiciones de decir que sobre la organización y composición social del ejército quedan varias cuestiones por trabajar que no han sido consideradas. En parte se debe al tratamiento dispensado a la documentación y por los marcos teóricos utilizados. Por lo tanto, trataremos las problemáticas desde una perspectiva que involucra a la relación social desarrollada entre los dos sujetos que participaron en la guerra como comandantes y comandados.

Llegados al final del balance historiográfico, revalorizamos los argumentos que sostienen que el ejército estaba compuesto por milicias rurales/ élites entrenadas privadas y que su forma de agregación al ejército regio fue siguiendo a un cabecilla aristócrata. No obstante, nos resulta más difícil aceptar que los grandes propietarios controlasen a sus habitantes y a sus tierras ejerciendo un poder de tipo feudal ${ }^{689}$ (perspectiva historiográfica que está en plena revisión ${ }^{690}$ ). De la interpretación realizada por los continuistas sobre este mismo fenómeno, estamos de acuerdo con la proposición sobre el carácter del rey como jefe del ejército, mas también advertimos que en la realidad social los guerreros no siempre combatieron por el bando regio, como veremos más adelante. Las demonstraciones de Halsall - en especial sobre las relaciones laxas desarrolladas entre los líderes militares y sus subordinados y las observaciones sobre los reyezuelos del norte de Europa- constituyen planteos sólidos que incitan a pensar que la relación clientelar jefe militar-soldado visigodo sería mucho más laxa de lo que la historiografía seguidora de Barbero y Vigil y la corriente continuista suponen, y que los hombres libres y clientes podrían cambiar de jefe, incluso si éste era el rey.

\section{2}

\section{El ejército regio}

\footnotetext{
${ }^{689}$ IsLA FREZ, A.: Ejército, sociedad y política en la Península Ibérica entre los siglos VII y XI ..., p. 228; DíAZ MARTínEZ, P.C.: "La dinámica del poder y la defensa del territorio: para una comprensión del fin del reino visigodo de Toledo", p. 187.

${ }^{690}$ Ver: Collins, R.: La España Visigoda 409-711 .., p. 8 y ss.
} 
En los capítulos anteriores observamos que la aristocracia visigoda era materialmente pobre y con un radio limitado de acción política. Las características del periodo hicieron que los maiores de la sociedad se relacionasen con un número significativo de sujetos libres pertenecientes a estratos sociales inferiores a través de vínculos laxos; estas relaciones de dependencia no necesariamente se transformaban en relaciones de explotación. Esta misma pauta de comportamiento, en su gran mayoría, la encontramos en las relaciones clientelares formadas por los guerreros y los líderes aristocráticos, tal como lo indica Halsall para el resto de Europa en su periodo temprano medieval. Sanz demuestra la existencia desde el siglo IV de ejércitos privados que respondían a los poderosos locales; y en Hispania en los siglos VI y VII las milicias godas junto a sus líderes actuaban en favor o en contra de los intereses de los reyes (o manteniéndose neutral y a la espera) ${ }^{691}$. Siguiendo estos aportes historiográficos, planteamos que estas unidades políticamente atomizadas, que funcionaban bajo la lógica clientelística, se reunirían según la capacidad de convocatoria del rey de turno.

Aquí indagaremos sobre los aspectos políticos-sociales y económicos de la relación clientelar descripta. En el primer apartado, observaremos las bases organizacionales del ejército que respondía al rey godo. Demostraremos que el ejército regio era un organismo compuesto por múltiples jefaturas comandadas por miembros de la aristocracia, cuya responsabilidad fue reclutar y disponer de sus tropas para el rey y, de ser necesario, dirigirlas en su nombre. En el segundo apartado, analizaremos la extracción social de los guerreros sin distinciones de categorías especiales a fin de comprobar que, además de los esclavos y los dependientes más directos de los grandes del reino, los hombres libres propietarios también brindaban sus servicios de armas. Luego, constataremos que los clientes militares podían abandonar a su líder de un modo más sencillo de lo que los historiadores enmarcados en la tesis del feudalismo visigodo sostienen. Por último, examinaremos las recompensas que recibían los guerreros que integraban las huestes del rey bajo comando aristocrático.

\section{Las bases organizacionales del ejército regio}

El primer punto por tratar es el mecanismo de la leva militar, problema que atañe directamente a la organización del ejército en su dimensión política. Como señalamos, los

\footnotetext{
${ }^{691}$ SANZ, R.: “Aproximación al estudio de los ejércitos privados en Hispania durante la antigüedad tardía”, Gerión, 1986, vol. 4, pp. 225-264.
} 
principales documentos utilizados por los historiadores son las leyes. Advierte Sánchez Albornoz que

“(...) no poseemos en verdad leyes reguladoras del ordenamiento militar visigodo. Las recogidas en el Liber Judiciorum tendían a castigar abusos, deserciones, flaqueza (...); o procuraban resolver algunas cuestiones de derecho civil que podían surgir como corolario de concretas acciones bélicas." ${ }^{692}$

Ahora bien, esta sentencia es aplicable en parte al conjunto de leyes consideradas antiguas, que perduraba en las sucesivas revisiones de la legislación visigoda; sin embargo, dos leyes particulares, que fueron promulgadas una en el año 673 por Wamba $\left(9,2,8^{693}\right)$ y la otra en el 681 por Ervigio $\left(9,2,9^{694}\right)$, constituyeron una excepción. De fuerte carácter político, estuvieron destinadas a sancionar más que a regular el funcionamiento militar. No obstante, un examen minucioso arroja elementos de la organización del ejército, que paralelamente encontramos en otro tipo de fuentes. Asimismo, la ley de Égica $\left(5,7,19^{695}\right)$ aporta algunos datos que iluminan la cuestión sobre el reclutamiento de las tropas y los vínculos políticos.

Según Sánchez Albornoz y King, el conjunto de leyes referentes al ejército tuvo la misión de organizar el encuadramiento de los potenciales hombres armados en thiufas, centenas y decanías, una realidad anterior a la reunión del ejército. Sin embargo, el objetivo de estas leyes fue castigar los delitos relacionados con los deberes militares. Veamos su detalle $^{696}$ :

-9, 2, 1 “Si hi, qui exercitui prepositi sunt, commodis corrupti aliquem de expeditione domum redire permiserint vel a domibus suis exire non coegerint": esta ley multaba con un pago nueve veces el valor del recibido como soborno de manos de un hombre que deseaba convertirse en desertor; además, agregó que si los oficiales (tiufado, quingentenario, centenario o decano) no obligasen a los hombre a salir de sus casas y unirse al ejército los

\footnotetext{
${ }^{692}$ SÁNCHEZ AlBORNOZ, C.: "El ejército visigodo: su protofeudalización”, pp. 6 y 7.

${ }^{693}$ LV, 9, 2, 8, “Quid debeat observari, si scandalum infra fines Spanie exsurrexerit”, p. 370.

${ }^{694}$ Ibidem, 9, 2, 9, "De his, qui in exercitum constituto die, loco vel tempore definito non successerint aut refugerint; vel que pars servorum uniuscuiusque in eadem expeditione debeat proficisci” p. 374.

695 Ibidem, p. 243-244.

${ }^{696}$ Las leyes por tratar son $L V, 9,2,1-6$, pp. 366-369. Se copia de cada una solo el título.
} 
oficiales nombrados deberían pagar 20,15, 10 y 5 sueldos respectivamente, siempre y cuando no se comprobase la entrega de un soborno.

-9, 2, 2 "Si conpulsores exersitus aliquid, dum exercitum ad ostem conpellunt, de domibus eorum auferre presumserint": si un encargado del reclutamiento militar robase en la casa de uno convocado a la guerra, reintegraría once veces el valor de lo tomado y recibiría cincuenta latigazos en público.

-9, 2, 3 "Si prepositi exercitus relicto bello ad domun redeant aut alios redire permittant": aquí la ley señalaba que, si un centenario abandonaba su puesto, sería condenado a muerte por decapitación; e incitaba a castigar al centenario que facilitara la deserción de un hombre a cambio de un soborno.

-9, 2, 4 "Si prepositi exercitus aut relicta expeditione ad domun redeant aut alios exire minime conpellant": la condena de un decano desertor se estimó en diez sueldos o cinco si ayudase a uno de sus hombres; también los azotes y diez sueldos fueron los castigos estipulados para quien no respondiera a la llamada al ejército o desertara del mismo sin el consentimiento del tiufado, quingentenario, centenario o decano.

-9, 2, 5 "Si conpulsores exercitus beneficio accepto aliquem sine egritudine domu stare permiserint": en esta ocasión se castigaría a los servi dominici (encargados de realizar la llamada al ejército) a pagar al conde de la ciudad once veces el monto recibido por aquellos a los que eximiese de servir militarmente. Asimismo, los tiufados a través de sus centenarios, y a los centenarios a través de los decanos, deberían investigar la deserción e informar al comes ciuitatis los nombres de todos aquellos que cometiesen el dicho delito de deserción. Si un tiufado dilatara o entorpeciese la llegada de los resultados de la investigación se lo condenaría al pago de nueve veces el valor de lo recibido con tal fin. Para incentivar estas pesquisas propusieron la distribución de los pagos realizados por los culpables entre los miembros de sus divisiones.

-9, 2, 6 "De his, qui annonas distribuendas accipiunt vel fraudere presumunt" ${ }^{\text {"697: }}$ : esta ley reguló el castigo que soportaría aquel que obstaculizase por negligencia o con intención la recolección y distribución de los pertrechos y provisiones destinadas al ejército.

Más allá de las situaciones hipotéticas y las especulaciones nacidas a partir de las regulaciones vistas, es preciso detectar los elementos que componían la estructura de las

${ }^{697}$ Esta ley será retomada para estudiar el problema del pago a los soldados. 
milicias del siglo VII. Díaz Martínez postula que el conjunto de estas leyes antiquae, preservadas por las revisiones del código legal de Recesvinto y Ervigio, demuestran que los responsables del reclutamiento militar eran los conpulsores exercitus, quienes respondían ante el comes civitatis. Los otros oficiales eran garantes del cumplimiento del servicio militar de los reclutas ${ }^{698}$. Esta situación sufrió cambios que se reflejaron en las nuevas leyes introducidas en los años 673 y 681.

En nuestra opinión, las leyes antiguas 9, 2, 1-6 describieron una organización decimal del ejército que no se correspondía con la realidad de la mitad del siglo VI y el VII. Pero los problemas de deserción sí tuvieron una gran magnitud (a juzgar por los testimonios), lo cual impulsó a preservar las normas antiguas. La preocupación por mantener el orden dentro de las filas del ejército no solo se encuentra en el conjunto de leyes al cual pasamos revista, sino también en aquellas que castigaron los delitos cometidos por los guerreros $\left(8,1,1-9^{699}\right)$ y en las advertencias realizadas por Wamba a sus propios soldados, según el relato de Julián. Avancemos ahora sobre el análisis de las leyes promulgadas por Wamba y Ervigio, que echan más luz sobre la estructura organizacional del ejército del siglo VII.

Wamba tuvo que enfrentar una rebelión abierta en territorio Tarraconense. Finalizada la misma, el rey triunfante dictó una ley cuyo propósito mayor fue instar a los miembros de las clases sociales altas a defender el reino cuando fuese necesario. Comienza reflexionando sobre la existencia de unos malos usos alentados por la indiferencia de aquellos que no cumplían con su deber y que dañaban a la patria ${ }^{700}$. Con el objetivo de abolir las razones que afectaron a los intereses del reino decretó que ante "aliqua infestatio inimicorum"701 todo hombre útil (obispo o miembros del clero, duque, conde, tiufado, gardingo, vicario o cualquier persona) del lugar en el que ocurriese el ataque o se encontrase a una distancia de cien millas debería combatir a los invasores sin demora. Quien no cumpliera esta disposición por retrasar su llegada al lugar del combate, no ayudara en la defensa "cum omni virtute sua ${ }^{, 702}$ o bajo pretextos intentara eludir su responsabilidad, perjudicando al reino y sus

\footnotetext{
${ }^{698}$ DÍAZ MARTíNEZ, P.C.: "La dinámica del poder y la defensa del territorio: para una comprensión del fin del reino visigodo de Toledo". p. 199.

${ }^{699} L V, 8,1,4$, p. 314; 8, 1, 8, p. 316; 81,9 , p.317.

${ }^{700}$ Ibidem, 9, 2, 8, p. 370.

${ }^{701}$ Ibidem, p. 371.

${ }^{702}$ Idem.
} 
habitantes, recibiría un castigo de acuerdo con su orden social. Entonces, cualquiera que, por atraso, por miedo, malicia o tibieza no defendiese el reino, y por su actuación y falta de cooperación se produjesen daños, o algún habitante del reino fuese capturado, si era miembro de la Iglesia, al no contar con medios propios para compensar los daños producidos por su negligencia, sería desterrado al lugar que el rey seleccionase; si era laico perdería su dignidad, sus propiedades y sería reducido a la condición de esclavo. La ley recalcó que las penas incluían la pérdida de la dignidad en caso en que los culpables no hubieran actuado con valentía.

En una segunda instancia, la ley señaló que ante un scandalum in quacumque parte contra gentem vel patriam nostrumque regnum vel etiam successorum nostrorum ${ }^{703}$, tanto laicos como eclesiásticos deberían acudir a la defensa o someterse a las penas ya descritas.

Isla Frez interpreta — creemos que correctamente - que esta ley no tuvo como objetivo principal regular la convocatoria militar regia, sino condenar a aquellos personajes que habían mostrado pasividad ante las sublevaciones de Hilderico y de Paulo. Para este autor "era una ley de contenido fundamentalmente político que subrayaba la debilidad del compromiso de los poderes locales" ${ }^{704}$. Barbero y Vigil entienden que se ordenaba a los miembros de la aristocracia apersonarse con sus ejércitos privados en los campos de batalla donde el rey se presentara. Para sostener sus dichos estos autores citan de la ley la frase "cum omni virtute sua”, que interpretan como “(...) todas sus fuerzas disponibles, en las que se incluirían evidentemente ingenuos y siervos" ${ }^{\text {705 }}$. Arce no acepta esta afirmación, sosteniendo que la ley no aludió a ejércitos privados, por lo tanto, estos dos autores confundieron "las gentes que trabajan para un propietario con su ejército privado"706.

De esta normativa, resaltamos el punto que obligaba a los miembros de la aristocracia a equipar, coordinar y comandar a sus hombres y combatir a los enemigos del rey, sin esperar la orden ante una invasión o una rebelión doméstica. La autonomía de acción militar fue evidente, así como lo fue el ejercicio del poder político en otros asuntos de gobierno vistos en el capítulo anterior. Esta facultad se profesó con bastante frecuencia por los grandes dignatarios del reino; prueba de ello fueron las delegaciones del comando del ejército por

\footnotetext{
${ }^{703} L V, 9,2.8$, p. 372.

${ }^{704}$ ISLA FREZ, A.: Ejército, sociedad y política en la Península Ibérica entre los siglos VII y XI ..., p. 51.

${ }^{705}$ BARbero, A. \& VigIL, M: La formación del feudalismo en la Península Ibérica ..., p. 47.

${ }^{706}$ ARCE, J.: Esperando a los árabes: los visigodos en Hispania (507-711) .... p. 126.
} 
parte de los reyes a ciertos hombres de confianza con el fin de cumplir una misión especial ${ }^{707}$. Una vez realizado el traspaso del dominio del rey a condes o duques, las estrategias militares eran exclusiva responsabilidad del delegado, así como las actividades de las unidades de combate. El temprano episodio transcurrido durante el reinado de Recaredo protagonizado por el duque Claudio de la Lusitania constituye un gran ejemplo. Como hemos visto en el capítulo anterior, en el reinado del primer rey católico las tensiones entre los obispos arrianos y católicos se tornaron violentas, al punto tal que Claudio se vio obligado a intervenir en favor del obispo Masona de Mérida. Luego de desbaratar el plan de asesinato, apresar a algunos y matar a los que se resistieron, Claudio notificó a Recaredo de lo sucedido y, según el hagiógrafo de la $V S P E$, le sugirió que los laicos fueran privados de sus patrimonios y honores y enviados al exilio, mientras que Sunna recibiera la posibilidad de convertirse a la fe católica o se marchase para siempre de tierras hispanas ${ }^{708}$. Podemos notar que Claudio no debió esperar las órdenes de aceptación del plan por parte de Recaredo para enfrentar a los conjurados, a pesar de que su acto pudo haber inflamado aún más el tenso ánimo político del reino, y motivar más levantamientos arrianos (de hecho, hubo otras revueltas; sin embargo, no hay pruebas de la causalidad entre el suceso narrado y las revueltas contemporáneas y posteriores).

También la autonomía de acción de los grandes del reino la percibimos en su actuación posterior una vez instalados los árabes. Los aristócratas godos que se sometieron al dominio árabe tuvieron la legítima potestad de firmar tratados de capitulación. Collins analizando el avance de la conquista de los árabes y nombrando el pacto entre Abd al-Aziz y Teodomiro de Orihuela afirma:

"A medida que la conquista fuera avanzando, primero hacia el norte y después hacia el este,
se haría necesario dejar que la mayoría de las ciudades y regiones se gobernaran por sí solas,
a condición de que se mostrasen dispuestas a colaborar (...) esto se lograría mediante el

\footnotetext{
${ }^{707}$ Han sobrevivido varias noticias alusivas sobre duques que han marchado frente a las tropas a combatir a los enemigos por orden del rey, a saber: Claudio, Richilane, Suíntila y Paulo. Este punto ya fue tratado en el capítulo anterior.

${ }^{708}$ El episodio narrado lo hallamos en VSPE, p. 88. El accionar contra los condes arrianos debemos relacionarlo con las revueltas arrianas que Recaredo debió reprimir a partir de su conversión en el año 587 y el III Concilio de Toledo de 589. Las revueltas son descritas por Juan de Biclaro, IOHAN BICL. Chr., IsID. Hist. Goth., p. 262 y GREG. TUR. Hist. Franc., p. 450.
} 
establecimiento de pactos y tratados con los magnates de las distintas localidades, siendo el más célebre de todos ellos el conde Teodomiro, que poseía el control de seis pequeñas poblaciones situadas en la región suroriental de la costa levantina ibérica"709

Años después de la ley de Wamba, y en un contexto político distinto, Ervigio dictó su ley militar con el propósito de reglamentar la asistencia al ejército. En esta ley distinguimos con mayor claridad que fue responsabilidad de los grandes propietarios reunir a sus hombres para el servicio regio.

Con una denuncia sobre el incumplimiento de los deberes de todos los hombres para con el reino comienza la ley 9, 2, 9. Allí se acusa a quienes no se alistaron en el ejército inmediatamente, a los que habiendo sido notificados decidieron quedarse en sus hogares o se incorporaron al ejército sin armas o equipos; también se condena la forma de actuar de muchos que, anteponiendo su propio beneficio y seguridad, dispusieron de menos de la vigésima parte de "sue familiae" $"$, pues prefirieron que sus miembros trabajaran en sus tierras; $y$, si la victoria los acompañaba, disfrutar de los frutos producidos, antes que participar en las guerras. Por lo tanto, fue necesario castigar a aquellos sujetos que no cumplieron con sus deberes. Se reglamentó que todos los "populis regni nostri” deberían presentarse en el día y lugar de la reunión del ejército fijada en la convocatoria realizada por el rey o un duque o conde y ninguno podría desertar. Los sujetos considerados maiores (duques, condes y gardingos) que no se presentasen sufrirían el exilio y la confiscación de sus bienes. Los inferiores o viliores (tiufado, exercitus conpulsores, y guerreros) que por negligentes o fraude no marcharan a la reunión recibirían doscientos latigazos, se les arrancaría el cuero cabelludo y pagarían una libra de oro; si no poseyeren la cuantía suficiente serían esclavizados y sus bienes pasarían a manos del rey, quien los administraría a su antojo. La ley estipuló que los duques, condes, gardingos, godos, romanos, ingenuos, manumitidos o siervos fiscales acudiesen a la reunión del ejército con la décima parte de sus siervos; los mismos deberían estar provistos de las armas adecuadas y protección. Si no cumpliesen con esta disposición quedarían bajo la autoridad del rey. En caso de que un miembro del oficio palatino se negase a acompañar a su rey sufriría la confiscación de sus bienes, a menos que se encontrase

\footnotetext{
${ }^{709}$ Collins, R.: Califas y reyes. España, 796-1031, Barcelona, Crítica, 2013, p. 25. MAÍllo SALGADO, F.: Acerca de la conquista árabe de Hispania: imprecisiones, equívocos y patrañas, Gijón: Trea, 2011 p. 102.

${ }^{710} L V, 9,2,9$, p. 374. Así en el original.
} 
enfermo. También se estipuló el castigo para los exercitales que ya en funciones militares no siguieran a su duque, conde o patrono, y abandonase la wardia, recibirían la pena estipulada para los inferiores. Finalmente, se fijó que, si un duque, conde, tiufado u otro encargado del ordenamiento del ejército aceptara sobornos de quien quisiera liberarse de cumplir su obligación militar y así lo lograse, los de mayor rango devolverían cuatro veces lo recibido y pagarían una libra de oro al rey, mientras que los considerados inferiores serían privados de su honor y dignidad de ingenuos y sometidos a la potestad del rey.

En el año 693 o 694 se sancionó la ley sobre la convocatoria de los libertos por Égica. Según García López, esta ley complementó la lista de convocados por las leyes de Wamba y de Ervigio, aunque estuvo destinada a un grupo privilegiado, como fue el conformado por los libertos del rey. Mas, sostiene esta autora, que lo esencial de la ley egiciana fue el objetivo que buscó: que los libertos fiscales y sus descendientes se incorporasen a la hueste regia y no a las ajenas (per patrocinia diursorum se dilatare ${ }^{711}$ ). Más allá del propósito explícito, ciertos pasajes de la redacción proporcionan elementos muy importantes para el fin de esta investigación. Copiamos el texto de forma íntegra y destacamos los pasajes para nosotros significativos $^{712}$ :

De libertis regum eorumque posteritate, qualiter exercitui tempore ad regiam potestatem concurrant, uel cum quibus eos in publica utilitate profisci oporteat.

Tunc rite nostri regiminis patriam promulgatis legum censuris regere procuramus, $q u<u>m$ et his qui contra hostes glorie nostre decertantur cautela máxima prouidemus, et uindicatores terre nostre procul dubio cernimus.

Et licet, fabente deo, gentis nostre affluant copie bellatorum, nil tamen officit si de illis augeantur insuper nostre acies ad repulsionem ostium externorum qui ex familiis fisci per regias auctoritates libertatis gratiam meruerunt. Unde quia necesse est ut illic prebeant ex ratione suffectum unde meruisse letantur absolutionis istatum, ob hoc ispeciali sanctione iubemus ut deinceps tam ipsi quam omnis eorum posteritas tempore exercitui omnes ad regiam celsitudinem incunctanter occurrant, ut cum quibus exercitus expeditionem peragere possint, presentaliter eos clementia principalis instituat. Quicumque

\footnotetext{
${ }^{711}$ Ibidem, 5, 7, 19. GARCÍA LÓPEZ, Y.: Estudios críticos y literarios de la "Lex Wisigothorum", Universidad de Alcalá, 1996, pp. 421-424.

${ }^{712}$ Utilizamos la edición de García López.
} 
uero ex eis, ut dictum est, tempore exercitus domui residere presumserit et minime cum ceteris, sicut regalis hordinatio fuerit, in publica expeditione perrexerit, nouerit se ad proprie seruitutis iugum reuerti, ex quo ereptus libertatis meruerat personam adsummere. Illi tantummodo hanc erunt sententiam modis omnibus euasuri, qui hordinante principe, duce uel comite suo aliquid iniunctum pro publicis utilitatibus ad peragendum acceperint, uel quos patens egritudo aut quorundam inpedimentum nullatenus properare permiserit.

En primer lugar, enfatizamos las palabras utilizadas por Égica para destacar que una multitud de guerreros (gentis nostre affluant copie bellatorum) concurrieron para unirse a su hueste; estos bellatores pertenecieron, por las palabras del rey, a su núcleo cercano. Probablemente serían aquellos miembros de la aristocracia que las fuentes tantas veces nombran con los términos fideles regis. En segundo lugar, se instó a los libertos a contribuir con la ayuda debida (es decir, sus brazos para luchar por el rey porque fue él quien les otorgó la condición de libres), haciendo explícita la obligación y el derecho de todo hombre libre de participar en las campañas públicas. Además, una vez llegados al lugar de la reunión del ejército, el rey en persona les indicaría con quiénes realizarían la campaña bélica; esto significó que en el ideal jurídico el rey continuaba siendo la cabeza del ejército como en todo el siglo y medio anterior. Más interesante y revelador es la última parte de esta normativa: la eximición de la convocatoria a los libertos que estuviesen en una misión por encargo del rey, un duque o su conde. Esto significa que ciertas fuerzas militares del reino actuaban por el bien de todo el reino, pero de forma autónoma, sin esperar las órdenes directas del rey, tal como lo hemos visto en el caso del dux Claudio.

Las disposiciones legisladas aportan elementos en relación con la organización militar que son necesarios evaluar.

En primer lugar, se desprende de estas leyes que fueron las grandes dignidades del reino quienes organizaban a sus hombres en unidades, que los equipaban con armas y lorigas si era necesario, y juntos marchaban a la guerra. Lo revela también un pasaje de la Vita Fructuosi, escrita en la región de Braga hacia el año $675^{713}$. El hagiógrafo anónimo narró el formidable ingreso de una multitud de hombres al monasterio fundado en la Bética por el

\footnotetext{
${ }^{713}$ M MARTín IgLeSIAS J.C. Y ANDRÉS SANZ, M.A.: Estudio crítico. Fructuoso de Braga, Madrid: Fundación Ignacio Larramendi, 2011, p. 1.
} 
santo. Tal situación inquietó al duque provincial y a los duques de los territorios vecinos quienes reclamaron al rey medidas para restringir dicho fenómeno, o que se preparara para sufrir la consecuencia de no contar con sujetos para integrar la expeditione publica; advirtieron que de seguir la situación lo único que se lograría sería un ejército de monjes ${ }^{714}$. Tal vez la preocupación de los líderes militares se generó porque el fervor religioso de la muchedumbre se traduciría en una reducción potencial del número de guerreros. Además, una vez convertidos en hombres religiosos no podrían empuñar un arma, ya que las leyes religiosas prohibían a los clérigos el derramamiento de sangre ${ }^{715}$.

Las competencias de los grandes del reino no se limitaron a la organización de los cuadros militares. Otras funciones importantes se destacan tanto en las leyes como en otras fuentes: la capacidad de movilizar las tropas por su liderazgo y el ejercicio del poder político en cuestiones tocantes al destino del ejército regio.

La primera cuestión por atender radica en la actitud negativa de los líderes, pues era la que aquietaba el ánimo de combate de sus tropas, no cumpliendo con sus deberes para con su rey. Gracias al relato sobre la rebelión contra Wamba accedemos a un caso concreto. Julián de Toledo denunció que el duque Paulo llevó con evidente deseo el desánimo a los jóvenes de su ejército cuando avanzó lentamente, con interrupciones y, sobre todo, cuando en las primeras escaramuzas se mantuvo aparte y no dirigió los primeros ataques. Su actitud se comprende porque quiso derrotar la embrionaria sedición que surgió en la Galia (al contrario, quería comandarla $\left.{ }^{716}\right)$. Por otro lado, observar que fueron los duques, condes y gardingos quienes recibirían un soborno y dispensarían del servicio de la guerra a aquellos que lo solicitasen, habilita a suponer que estos a través del ejercicio del poder político podrían liberar de su obligación a esos propietarios que no quisieran abandonar sus tierras de labor. Es lícito suponer que para concretar el "acto de soborno" que las leyes denuncian era necesario la existencia de un vínculo de cercanía muy fuerte entre el que deseaba liberarse y

\footnotetext{
714 Vit. Fruct, p. 106.

715 Concilios, Toledo I, año 397, c. VIII, p.22; Lérida, año 546, c. I, p. 55; Toledo IV, año 633, c. XLV, p. 207; Toledo XI, año 655, c. VI, p. 360. Sobre este tema, encontramos una contradicción entre la legislación de origen eclesiástica y lo estipulado por los reyes. La Iglesia pretendió que sus miembros no se involucren en las guerras, mas numerosos son los ejemplos que indican que sucedía lo contrario. Tal vez por eso los reyes le pidieron su lealtad y que participen en la defensa del reino, ya que, a pesar de las leyes, los clérigos se involucraron igual en las disputas políticas, las cuales muchas veces terminaban con derramamientos de sangre.

${ }^{716}$ IUL. TOL. $H W$, p. 222.
} 
el que tuvo la capacidad de hacerlo; una relación en la cual la esperanza firme de cumplir lo prometido debió ser fundamental. Es más, podríamos interpretar a este intercambio de favores como una práctica reciprocitaria, un mecanismo temprano de acumulación patrimonial por parte de la aristocracia a través de sus funciones públicas ${ }^{717}$.

Estamos de acuerdo con Isla Frez cuando defiende que las leyes "describen un ejército formado por colectivos (...)"718; por lo tanto, el ejército visigodo podría ser entendido como un conjunto de unidades comandadas cada una por un aristócrata en su rol de líder militar, tal como lo sugieren las leyes al expresar que los convocados deberían permanecer con sus duques o condes, o cumplir misiones especiales por encargo de estos últimos.

La aristocracia ordenaba a partir de su amplio grupo de dependientes a sus clientelas armadas, que constituían un grupo privilegiado de patrocinados que acompañaban a su jefe a la guerra por una paga nada desdeñable. Así lo demuestran una ley que reguló las ganancias obtenidas durante la guerra por los dependientes de la esposa, las leyes que regulan las relaciones de clientela de tipo militar ${ }^{719}$ y la inscripción funeraria destinada a recordar a Oppila datada en el año $642^{720}$.

En la lápida citada son mencionados tres grupos de individuos que actuaron de distinta forma en el episodio posterior a la muerte del aristócrata. En primer lugar, se nombra a los sodales, los compañeros que abandonaron el cuerpo en el campo de batalla ${ }^{721}$; el segundo grupo estuvo constituido por los clintes (en el texto original), o clientes, quienes recuperaron el cadáver y lo trasladaron hasta los dominios de Oppila; y el último grupo, los uernuli, los encargados de dar sepultura y brindar honores al noble guerrero en su última morada.

Una ley destinada a disponer sobre la división de los bienes adquiridos durante el matrimonio, y sin relación aparente con la organización militar ${ }^{722}$, dictaminó que las

\footnotetext{
${ }^{717}$ AstARITA, C.: "Prácticas del conde y formación del Feudalismo: siglos VIII al XI", Anales de la Universidad de Alicante: Historia medieval, 14, 2003-2006, pp.21-52.

718 ISLA FREZ, A.: Ejército, sociedad y política en la Península Ibérica entre los siglos VII y XI ..., p. 59.

719 Ver SÁNCHEZ AlBORNOZ, C.: "El ejército visigodo: su protofeudalización”. p. 34 y ss; especialmente la referencia sobre bucelarios y sayones como constituyentes del séquito armado de los grandes del reino.

${ }^{720}$ Ver nota 102.

721 Moreno Resano propone que fueron guerreros de origen aristocrático. Moreno ReSANO, E.: "La representación épica del combate y de la muerte del guerrero en el epitafio de Opilano (año 642)", Habis, 42, 2011, p. 305.

${ }^{722} L V, 4,2,15$, p. 183.
} 
ganancias obtenidas por el marido en una expedición llevada a cabo con los dependientes de su esposa - englobados bajo el término servi - le corresponderían. Asimismo, indemnizaría a las víctimas si hubiese daños causados por este grupo bajo su comandancia, ya que disfrutaría de las ganancias obtenidas. Otras leyes $(8,1,8$ y 9$)$ insisten en hacer responsables a los domini de los delitos cometidos por sus servi durante las expediciones militares. Estos indicios documentales muestran claramente que los propietarios y sus dependientes se convertían en una unidad militar bajo la guía y responsabilidad del jefe.

Asimismo, podemos observar que los guerreros congregados bajo estandarte regio continuarían unidos al jefe aristócrata que los reclutó, como lo marcó la ley arriba señalada y como se observa en un episodio relatado por Julián: cuando Paulo fue enviado por Wamba a sofocar los primeros momentos de la sedición lo hizo con parte del ejército. En episodios posteriores nuestro cronista señala que cierto número de esos soldados habían venido con él desde Hispania (la rebelión se desarrollaba en la Tarraconense) ${ }^{723}$.

Ahora bien, los elementos vistos no son concluyentes sobre la naturaleza del ejército visigodo, ni sobre los vínculos existentes en el seno de este. Solo destacan la importancia de la aristocracia como organizadora de los grupos de combatientes, que de acuerdo con los vínculos políticos y las recompensas ofrecidas luchaban a favor o en contra del rey. Entonces, si abandonásemos el análisis aquí caeríamos en el equívoco de plantear que el ejército visigodo era un ejército formado exclusivamente por dependientes con un alto grado de sujeción debida y sin márgenes de decisión política. Este problema necesita una solución.

Por tanto, en el próximo apartado abordaremos la cuestión de la extracción social de los guerreros. La reflexión sobre la misma permitirá comprender de manera más acabada la relación clientelar que se desarrolló en el marco del ejército visigodo. Sostenemos que parte de esos guerreros mantenían con la aristocracia vínculos políticos basados en una relación de tipo reciprocitaria, que fácilmente podría ser rota si el beneficio prometido no se cumpliera.

\section{La extracción social de los guerreros-clientes}

\footnotetext{
${ }^{723}$ IUL. TOL. $H W, \mathrm{p}, 234$.
} 
Díaz Martínez demuestra que en Hispania las relaciones clientelares interpersonales se habían extendido, y la fidelidad jugó un rol esencial ${ }^{724}$. Estas relaciones de patrocinio fueron constatadas por el autor en las Fórmulas 32, 36 y 37, así como en una serie de leyes que establecieron "una crítica" al sistema clientelar. En la ley 2, 2, 8 se recogió la denuncia contra los maiores personae que intervendrían en los juicios a favor de sus patrocinados. Allí mismo, también, se les advertía que no se presentasen con sus séquitos a causar tumultos ( 2 , 2, 2), y los jueces no deberían tener piedad de un acusado por las relaciones de patrocinio de este $(7,4,6)$. El análisis muestra que cierta legislación registró a una categoría de patrocinados privilegiados que se relacionaban con su patrón de forma voluntaria y revocable. En la mayoría de los casos estaríamos frente a vínculos desarrollados en el marco de una encomienda libre de tipo militar.

Siguiendo esta línea de investigación, ahora intentaremos precisar qué segmentos de la población compusieron las huestes que acompañaban a los aristócratas a la guerra. Veremos que las clientelas armadas estaban conformadas por un conglomerado de dependientes de estatus jurídicos diferentes, una característica no privativa del mundo visigodo.

Le Jan indica que los jefes guerreros merovingios reclutaban de sus dominios, y entre sus dependientes libres y no libres, a los soldados que formaban sus bandas armadas privadas, cohesionadas durante la guerra y la paz. Del mismo modo, la aristocracia agrupaba a sus guerreros domésticos, sus parientes y a sus amigos ${ }^{725}$ en grupos armados heterogéneos, fuertemente jerarquizados y al mismo tiempo atravesados por relaciones horizontales afectivas, reflejadas en los vocablos socii, sodales y satellites ${ }^{726}$. Por su parte, Halsall, considerando las múltiples características regionales de Europa, concluye que hacia el siglo VII la leva de los ejércitos era una tarea de la aristocracia dueña de las tierras, que reclutaba de ellas a sus guerreros formando así sus bandas. Estos seguidores estaban vinculados a sus

\footnotetext{
${ }^{724}$ Por ejemplo, Pablo C. Díaz Martínez analizó la fórmula diplomática número 32, y concluyó que el contrato de sumisión allí redactado fue en realidad "un acuerdo encubierto de vinculación entre un patrono y un cliente". La fórmula finaliza con la frase "Quod etiam iuratione...", constituyendo un indicio claro de esta relación clientelar. DíAZ MARTíNEZ, P.C.: "Sumisión voluntaria: estatus degradado e indiferencia de estatus en la Hispania visigoda (FV 32)" ..., p. 521.

${ }^{725}$ Los pactos de amistad poseían validez jurídica, pero no creaban una relación de dependencia.

${ }^{726}$ LE JAN, R. : "Satellites et bandes armés dans le monde franc (VIIe-Xe siècles)", Actes de congrès de la Société des historiens médiévistes de l'enseignement supérieur public. 18 congrès, Montpellier, 1987, pp. 99101.
} 
líderes militares por recompensas, y la condición del líder se sustentaba en su sustrato socioeconómico preeminente ${ }^{727}$. Ambos autores acuerdan que el estatus del líder era intransferible, a la vez que observan la existencia de lazos flexibles e informales inherentes a las relaciones clientelares de tipo militar. Estas relaciones verticales y a la vez horizontales caracterizaron de forma particular a las bandas armadas. Constituyeron grupos de individuos de múltiples estatus jurídicos y sociales internamente cohesionados por rituales y actividades como el banquete ${ }^{728}$.

Siervos y libertos

Un gran problema que presenta el estudio de las fuentes es el empleo del término servi y familiae. Muchos historiadores, principalmente Thompson y más recientemente Halsall y Arce, interpretan a estos términos en su sentido más restringido, llegando a sostener que el ejército visigodo de fines del siglo VII estaría compuesto en su mayoría por esclavos. Encuentran una prueba de ello en el empleo de hondas y piedras por cierto grupo en el ataque contra Paulo comandada por Wamba, y en la letra legal que obligaba a la aristocracia a presentarse con un número elevado de dependientes serviles; mas sobre esta última cuestión, hacemos eco de la observación ya realizada por Sánchez Albornoz:

"Según la ley de Ervigio IX.2.9 los señores de siervos no llevaban a la guerra ni la vigésima parte de los suyos. Es decir que quien poseía cien acudía a la hueste con menos de cinco. ¿Cómo dudar de que los llevarían a su servicio personal?"729.

Isla Frez sostiene que el término servus utilizado en los documentos endureció "el principio de dominio y refuerza la tendencia a considerar a buena parte de la sociedad de este modo" ${ }^{730}$. Consideramos que esta última opinión correcta de algún modo, pero que esconde una diferencia esencial entre libres y siervos: la libertad legal de poner fin a la relación de patrocinio. Lo antedicho no equivale a desconocer la participación de dependientes serviles

\footnotetext{
${ }^{727}$ HALSALL, G.; Warfare and society in the Barbarian West, 450-900, p. 69-70.

${ }^{728}$ Ver también: GAUTIER, A.: "La competición en bandas armadas en Europa del Norte durante la Alta Edad Media”, Sociedades Precapitalista. Revista de Historia Social, vol. 3, 1, diciembre 2013.

${ }^{729}$ SÁNCHEZ AlBORNOZ, C.: "El ejército visigodo: su protofeudalización”. p. 30, n. 176.

${ }^{730}$ IsLA FreZ, A.: Ejército, sociedad y política en la Península Ibérica entre los siglos VII y XI ..., p. 80.
} 
y libertos en las actividades militares ${ }^{731}$, que surgen en las fuentes vistas; sin embargo, creemos que estos representaban un porcentaje menor de la composición total de las huestes.

\section{Clientes}

Un conjunto compuesto por cuatro leyes $(L V, 5,3,1-4)$ describe a un grupo especial de patrocinados que entraban en batalla: los bucelarios y los sayones. Solo la lectura en conjunto de estas leyes revela su real significado. La primera, de origen euriciana y conservada en el Liber Iudiciorum (LV 5, 3, 1- Cod. Eur. 310), tuvo como propósito principal regular las donaciones hechas a los bucelarios, sean armas u otros bienes. Se dispuso que lo donado permanecería en manos del patrocinado a menos que eligiese otro patrón y abandonase el actual, acción que podría llevar a cabo porque "quoniam ingenuus homo non potest prohiberi, quia in sua potestate consistit”. También se estipuló que, si el bucelario en servicio obtuviese bienes, le correspondería la mitad de ellos.

La segunda ley (Cod. Eur. 311, LV, 5, 3, 2) estableció: “Arma, quae saionibus pro obsequio dantur, nulla ratione repetantur; sed illa, que, dum saio est, adquisivit, in patroni potestate consistant" ${ }^{\prime 732}$. Es evidente que las dos leyes vistas tuvieron como principal fin regular las ganancias obtenidas por hombres ingenuos, que en patrocinio habían recibido armas (es de suponer obtenidas en batallas, saqueos o campañas públicas, como lo dictamina la ley 4, 2, 15), mas destacamos de este conjunto legal el reconocimiento de la existencia de bandas armadas conformadas por hombres libres, que cambiarían de patrono a costa de sus ganancias y de las donaciones recibidas.

La ley tercera del título es la pieza clave, es la que genera la unidad del conjunto y permite alcanzar un mayor grado de claridad sobre el problema. En ella se insiste en que aquel que desease abandonar a su patrón o serle infiel perdería la mitad de sus bienes. Por último, la cuarta ley regla que aquel que se encomendase debería recibir tierras por parte de su patrono. Observando el total del título legal estamos en condiciones de realizar las siguientes afirmaciones.

En primer lugar, las leyes indican con claridad que la entrega de tierras se realizaba a cambio del servicio de armas, lo cual no era un servicio menor. Todo aristócrata necesitaba

\footnotetext{
${ }^{731} L V, 5,7,19$, pp. 243 у 244.

${ }^{732}$ Ibidem, p. 217
} 
de un séquito - ya fuese para participar en la guerra con su rey, defender sus tierras de los ataques o ir en búsqueda de botines - que poseyese un sentido de fidelidad y ejerciese su apoyo político en los momentos de mayor necesidad. Asimismo, y en el mismo plano de importancia, el objetivo era salvaguardar la fidelidad prometida, hecho sumamente importante, porque no solo se aseguraría un número de seguidores, sino que eliminaría potenciales clientes de otro patrón, que posiblemente fuese su competidor ${ }^{733}$.

Es sumamente interesante que el abandono y la infidelidad recibieran el mismo castigo. Como plantea Díaz Martínez, las relaciones clientelares del periodo visigodo estaban atravesadas por lazos de fidelidad, pero estas se podían romper, trayendo consigo consecuencias medianamente reparables.

Ante lo visto, el análisis del título "de patronorum donationibus" reveló que las bandas armadas dirigidas por un patrono se rigieron por vínculos políticos basados en la fidelidad y en la entrega de los bienes obtenidos en las actividades militares emprendidas, como gran premio recibían tierras. Los bienes entregados eran conservados por la descendencia de los clientes mientras observaran la fidelidad al patrono o a sus herederos. En otras palabras, este intercambio recíproco desigual generaba como resultado relaciones asimétricas de dependencia, tal vez de por vida, pero no necesariamente conduciría a relaciones de explotación.

Teniendo en cuenta estas reflexiones, los datos extraídos de la lápida de Oppila observados más arriba cobran otra dimensión. Clientes y uernuli son categorías que pueden ser asociadas a la de hombres armados (jurídicamente libres o no) que rindieron tributo a su jefe caído en la guerra al llevar el cuerpo a sus dominios, visibilizando así su estrecho vínculo. Quizá este acompañamiento por parte de los clientes fuese el gesto que los herederos de Oppila necesitaban para conservar las relaciones clientelares, sea una manifestación real del alcance de la fidelidad prometida y esperada de la que hablan las leyes.

Otro dato documental indica que nuestra conclusión es correcta. Según relató Julián de Toledo, ante la inminente derrota de los rebeldes, uir quidam, e sua ortus familia ${ }^{734}$ le reprochó a Paulo que sus malas decisiones hicieron que recayera sobre todos los suyos un

\footnotetext{
${ }^{733}$ WOLF, E.: "Relaciones de parentesco, de amistad y de patronazgo en las sociedades complejas", en BANTON, M. (ed.): Antropología social de las sociedades complejas, Madrid: Alianza, 1980, p.34.

${ }^{734}$ IUL. TOL. $H W, p, 229$.
} 
gran desastre ${ }^{735}$. Este personaje, sin referencias de su nombre o condición social más que la vaga alusión de ser un hombre del $d u x$, fue quien en el relato atormentó a su líder con insultos. Julián puso en boca de un miembro de su círculo las desgraciadas decisiones que llevaron a la ruina a los seguidores de Paulo. Mas, este personaje no pertenecería a la aristocracia, pues otros socios de la rebelión, desesperados por el fracaso, lo rodearon y lo degollaron ante los ojos de Paulo, mientras este gritaba “(...)'Quid huic quaeritis?' (...) 'Meus est, non pereat $^{\prime}(. . .)^{\text {,736 }}$. Su lamento no bastó para salvarlo. Julián no brinda mayores datos, lo cual nos permite interpretar esta ausencia como la falta de una condición social ilustre. Pero esto no significa que fuese necesariamente de condición servil, antes bien quizá estemos frente a un cliente con un vínculo de fidelidad especial.

Con relación a esto último, las fuentes describen bajo diferentes términos a los colectivos que entraban en la lucha bajo el liderazgo de un aristócrata, sin dar cuenta de especificaciones jurídicas. Por un lado, Procopio de Cesarea relata cómo Teudis, en el siglo VI, reclutó de las tierras de su rica esposa hispanorromana una banda armada de dos mil doryphoroi (lanceros) ${ }^{737}$, sin entrar en detalles si eran campesinos libres o dependientes. Pero sin lugar a duda, estos guerreros estaban bajo su comandancia en calidad de ejército privado o guardia personal. Asimismo, la crónica sobre las luchas de Leovigildo para someter al territorio brinda otras pistas. Este rey para lograr el control efectivo de Córdoba (572) y Orospeda (577), y sus territorios circundantes, tuvo que matar a los campesinos que presentaron resistencias desde $\operatorname{los}_{\text {castillos }}{ }^{738}$. Posiblemente estos rebeldes estarían bajo las órdenes de los potentados locales, la referencia a la captura de Aspidio (loci seniorem $^{739}$, quien estuvo al mando de la resistencia en los montes Aregenses, cerca del límite

\footnotetext{
735 Idem: “' 'Quid hic', ait, 'adsistis? Vbi sunt consiliarii tui, qui te ad istud perduxerunt calamatitatis ludibrium? Quid tibi profuit contra tuos insurgere, cum nec tibi nec tuis nunc ualeas in tanta mortis clade prodesse?' ',

736 Ibidem, p. 230.

${ }^{737}$ Procopio de CeSAREA: De bello Gothico, cap. 12, 50, p. 126.

${ }^{738}$ IOHAN BICL. Chr., p. 63: "Leouegildus rex Cordubam ciuitatem diu Gothis rebellem nocte occupat et cesis hostibus propriam facit, multasque urbes et castella interfecta rusticorum multitudine in Gothorum dominium revuocat", Ibidem, p. 69. "Leouegildus rex Orospedam ingreditur et ciuitates atque castella eiusdem provincie occupat et suam prouinciam facit, et non multo post inibi rustici rebellantes a Gothis opprimuntur, et post hec integra a Gothis possidetur Orospeda."

${ }^{739}$ Ibidem, p. 67: "Leouegildus rex Aregenses montes ingreditur, Aspidium loci seniorem cum uxore et filiis captiuos ducit, opesque eius et loca in suam redigit potestatem”.
} 
Orense/León ${ }^{740}$ ) estaría señalando este hecho. A finales del siglo VII esta práctica continúa, como lo demuestran las referencias en las leyes, cánones conciliares ${ }^{741}$ y el ejército de Paulo, que estaba compuesto en parte por incolae provenientes de distintos territorios de Hispania $^{742}$.

Tal vez la reiterada alusión a la condición de incolae o rustici de muchos de los que entraban en la batalla estaría relacionada con la entrega de tierras que recibieran por parte del patrono $\mathrm{y}$, también, porque muchos eran propietarios, como veremos a continuación. Al compartir las condiciones sociales de producción (y quién sabe si la vecindad y los ámbitos de sociabilización), es posible que los cronistas eclesiásticos englobasen bajo estos términos a los cultivadores que no mostrarían diferencias reales de subsistencia, es decir, los estamentos jurídicos podrían ser más bien difusos.

Hombres libres propietarios

Como ya hemos señalado, la ley de Égica convocaba de manera obligatoria a los libertos a integrar las huestes regias porque habían recibido la condición de hombre libre en una escritura expedida por el rey. A su vez, se desprende de su lectura que la participación de los hombres de condición jurídica libre (llamados exercitales, que la ley los distanció de los servorum) era regular en los ejércitos bajo la comandancia de aristócratas. Estos fueron sujetos que contarían en su haber con por lo menos una libra de oro, multa fijada por infringir la norma; si no poseyeran esta cuantía sus bienes podrían ser incautados o perderían su libertad. Nos encontramos, entonces, ante un grupo de propietarios ingenuos que tuvieron la obligación de ir a la guerra y que podrían eludirla si entraban a formar parte del cuerpo de la Iglesia, tal como denunciaron los duques según el relato sobre Fructuoso de Braga o sobornando a su líder militar de la zona de su residencia.

Otro dato respalda esta afirmación: la legislación civil visigoda estableció la interrupción de los treinta años que podrían perjudicar a los possessores que se encontraban

\footnotetext{
${ }^{740}$ DíAz MARTínez, P.C.: El reino suevo (411-585), Madrid: Akal, 2011.p. 190.

${ }^{741}$ Concilios, p. 283: "Rusticarum plebium seditioso tumultu”,

742 IUL. TOL. HW, p. 234: "Nam suspectus iam et ipse ab incolis cum ceteris qui de Hispania cum illo commeauerant habebatur, ne ille ad liberationem sui traditionem eorum excogitaret, Spani uero, ne inrogata ab incolis morte transirent ad principem.".
} 
cumpliendo su deber en una campaña pública ${ }^{743}$. No es esta la única referencia sobre labriegos que marchaban hacia la batalla: el término familia de la ley de Ervigio, analizada más arriba, hace referencia a aquellos que cultivaban la tierra, pero que también acudían a la guerra con su patrón. Asimismo, durante estas campañas los expedicionarios eran los sujetos perpetradores de los crímenes ${ }^{744}$, mas también pudieron ser víctimas del pillaje como lo dictaminaron las leyes $9,2,2^{745}$ y $8,1,7^{746}$, elaboradas con el fin de proteger la propiedad y los bienes de aquellos que se encontraban fuera de sus hogares.

La intervención de los propietarios en la guerra junto a los reyes o condes fue una práctica social que pervivió en los territorios cristianos otrora dominados por los visigodos. Isla Frez sostiene que los hombres libres y propietarios tuvieron la obligación de acudir a la convocatoria militar realizada por el rey o los condes; no asistir significaba abandonar la parte del botín, y también su lugar en el orden social como privilegiados ${ }^{747}$.

Durante la formación del feudalismo la participación en la guerra continuó siendo un factor de suma importancia para la diferenciación social y económica (el caso de los Infanzones de Espeja constituye el caso paradigmático) al igual que en el periodo visigodo ${ }^{748}$. En el mundo árabe, según sugiere Petersen, fue posible que durante la entrada a la Península los invasores hayan continuado con la organización militar visigoda con la ayuda de los magantes, quienes se hicieron clientes o se convirtieron al islam ${ }^{749}$.

En este punto del desarrollo, podemos afirmar que estos hombres denominados por las fuentes como servi, uernuli, exercitales, clientes o familiae conformaban un colectivo de dependientes con diferentes estatus jurídico y grados de sujeción política. Poseían un vínculo estrecho con su patrón, una relación política con un fuerte componente económico, mas la disidencia podía existir. Y es aquí donde queremos poner el acento de ahora en más.

\footnotetext{
${ }^{743}$ LV , 10, 2 ,6 “De interruptione tricennii”, p. 394-395.

744 Sobre las consecuencias de las guerras sobre la población y la economía en general: ver capítulo 3.

${ }^{745}$ LV, p. 367.

${ }^{746}$ Ibidem, p. 316.

${ }^{747}$ Para el proceso de las obligaciones militares a rentas agrarias ver: ASTARITA, C.: "Prácticas del conde y formación del Feudalismo: siglos VIII al XI" y BONNASSIE, P.: "El señorío banal y los cambios en la condición del campesinado libre", en Little, L.; Rosenwein, W., (eds.), La Edad Media a debate, Madrid: Akal, 2003, p. 190-218.

748 AstARITA, C.: "Prácticas del conde y formación del Feudalismo: siglos VIII al XI".

749 PETERSEN, L.: Siege warfare and military organization in the successor states (400-800) ... p. 166.
} 


\section{3}

Los cambios de lealtad durante la guerra: la ruptura del vínculo guerrero-líder aristocrático

C. Martin analiza el pasaje de la Historia Wambae sobre el hombre de Paulo relatado más arriba y concluye que el vínculo que unía a los clientes con el patrón no era indisoluble, y que la imposibilidad de seguir brindando protección fue razón suficiente para romperlo ${ }^{750}$. Una de las referencias más extremas de la ruptura del lazo de patrocinio la encontramos en el capítulo tercero VSPE que ya hemos comentado ${ }^{751}$. Allí tiene lugar el relato sobre la entrega de una importante posesión fiscal por parte de Leovigildo a Nancto, y su posterior muerte en manos de los campesinos habitantes del lugar. Este pasaje revela que ante la presunción de los hombres sobre la incapacidad de su dominus de cumplir con su papel de protector no vacilaron en romper la relación de dependencia de la manera más brutal. También es pertinente traer a colación el episodio del obispo Justo (el obispo que murió estrangulado). Estos hechos más la indocilidad de la mano de obra visto en el capítulo tres, señalan lo habitual que fue recurrir a la violencia física para finalizar una relación de dominio insatisfactoria para los dependientes (no olvidemos la importancia que tenía el patrocinio episcopal en las ciudades basado fuertemente en el evergetismo ${ }^{752}$, ¿Justo, desempeñaría su rol tal como pretendía la comunidad?).

Estos casos nos resultan útiles para comenzar a entender que, si los vínculos de dependencia servil se rompieron con cierta frecuencia, los vínculos de subordinación voluntaria también podrían ser disueltos con facilidad. Como hemos visto, las leyes diseminadas en varios libros y títulos del cuerpo legislativo godo muestran que los hombres libres podrían romper sus lazos vinculares militares si así lo hubiesen querido ${ }^{753}$; los documentos no legales también nos aproximan a estas conclusiones.

Como ya hemos desarrollado en el capítulo anterior, muchas de las sublevaciones organizadas para derrocar al rey fueron posibles por la participación de los guerreros,

\footnotetext{
${ }^{750}$ MARTIN, C.: Lagéographie du pouvoir dans l'Espagne visigothique... p. 123.

${ }^{751}$ Ver capítulo 3.

${ }^{752}$ FuENTES HinOJO, P.: "Sucesión dinástica y legitimidad episcopal en la Mérida visigoda", En la España medieval, 35, 2012, pp. 11-33.

${ }^{753} L V, 5,3,1-4$. p. 216 y ss. y Cod. Eur. 311.
} 
alineados al grupo aristocrático faccioso. En varias ocasiones, estos guerreros respondieron originalmente al rey. El abandono de la fidelidad prometida al rey - la ruptura del vínculo — por parte de las tropas bajo la dirección de Paulo es el mejor ejemplo. La Historia Wambae brinda pasajes reveladores para entender la dinámica existente entre las jefaturas menores y los grandes del reino, y cómo un aristócrata ambicioso negociaba con los poderes locales y convencía a los soldados regios que combatieran por él a cambio de recompensas.

La revuelta contra Wamba en la Galia gótica tuvo como principal protagonista a Paulo, quien había sido enviado por el mismo rey a sofocarla, y terminó por convertirse en el líder de esta. Paulo, como principal instigador del tumulto, traicionó su vínculo con su rey. En Narbona frente a todo su ejército, formado por sus tropas personales ${ }^{754}$ más otras que Wamba le encomendó, se proclamó rey. Para asegurar su triunfo realizó promesas y ofreció $\operatorname{cargos}^{755}$. A pesar de todos los esfuerzos, el levantamiento de Paulo no tuvo éxito. En el último bastión paulino, la sospecha de traición comenzó a circular entre los allí reunidos incluso degollaron a un hombre de Paulo sólo por despertar desconfianza ${ }^{756}$ - . La desesperación y los reproches muestran que los acólitos del sedicioso temían que su líder los entregase a cambio de su salvación ${ }^{757}$. Como hemos visto, migrar de bando según las oportunidades era una práctica bastante común.

El cambio de lealtad y la ruptura de los lazos de fidelidad y dependencia no fue una práctica desconocida ni ajena a la sociedad visigoda marcada por el ritmo de la guerra. Todo lo contrario, la dinámica de agrupación y reagrupación encuentra su paralelo con el fenómeno de etnogénesis, proceso de definición de identidades sociopolíticas. Si bien el término etnogénesis causa debates historiográficos que parecen no tener fin $^{758}$, la mayoría de los

\footnotetext{
${ }^{754}$ IUL. TOL. $H W$, p. 234.

755 Ibidem, p. 224: “Vbi dum Paulus perfidiae suae socios numerosiores efficere uellet, prolatis promissisque muneribus (...)".

${ }^{756}$ Ibidem, p. 234.

${ }^{757}$ Idem: "Nam suspectus iam et ipse ab incolis cum ceteris qui de Hispania cum illo commeauerant habebatur, ne ille ad liberationem sui traditionem eorum excogitaret, Spani uero, ne inrogata ab incolis morte transirent ad principem”.

${ }^{758} \mathrm{La}$ etnogénesis es una tesis — planteada en principio por la historiografía vienesa - que explica las configuraciones étnicas durante las migraciones germánicas de los primeros siglos de nuestra era. Existe una amplia bibliografía sobre el modelo de etnogénesis y sus problemas teóricos y de aplicación, sobre todo se discute su rol en la formación de las identidades de los reinos sucesores del estado romano. Dos posiciones historiográficas se enfrentan de forma radical (defensores del modelo de Wenkus, como Wolfram, contra
} 
autores aceptan el carácter poliétnico de la población y la adopción de una identidad única como una elección política. Los conflictos bélicos redefinieron las constelaciones del poder político, y las bandas enfrentadas sufrían fracturas. Durante estos se desencadenan fases sucesivas de absorción y de recomposición identitaria en torno a los vencedores. Por lo tanto, no es de extrañar que ante la derrota el conjunto de guerreros, con o sin sus líderes, pactasen con el ejército vencedor, y menos extraño aún fue que éste aceptase a los derrotados en el seno de su grupo en un proceso de redefinición política. Hemos visto este mismo comportamiento entre la aristocracia y los reyes: el cuerpo de fideles regis fue dinámico y cambiante, reagrupándose en torno del victorioso.

Las formas de deshacer los vínculos clientelares de los guerreros y sus motivos (la falta de asegurar la protección o la victoria en la batalla) nos obligan a estudiar la próxima dimensión del problema que se presenta: las ganancias de los guerreros y patrocinados obtenidas durante las guerras; en otras palabras, las recompensas que mediaban esta relación de subordinación política ${ }^{759}$.

\footnotetext{
Goffart y Amory, por ejemplo) y no se vislumbra un posible consenso. Existe una tercera corriente historiográfica que se nutre de las dos tradiciones. Halsall y Heather son representantes de esta última posición. Ver principalmente: WenKUS, R.: Stammesbildung und Verfassung. Das Werden der frühmittelalterlichen Gentes, Colonia/Graz: Böhlau, 1961. Wolfram, H.: History of the Goths. AMORY, P.: "The meaning and purpose of ethnic terminology in the Burgundian laws", Early Medieval Europe, 1993, vol. 2, 1, p. 1-28. POHL, W.: "El concepto de etnia en los estudios de la Alta Edad Media", en LitTle, L.; Rosenwein, W., (eds.): $L a$ Edad Media a debate, Madrid: Akal, 2003, pp.35-49. GoffarT, W.: Barbarians and Roman A-D 418-584. The techniques of accommodation. Princeton, 1980 y "Los bárbaros en la Antigüedad tardía y su instalación en Occidente.”, en LitTle, L.; RosenweIn, W., (eds.), La Edad Media a debate, Madrid: Akal, 2003, pp.50-79. AZZARA, C.: Las invasiones bárbaras, Valencia: Universidad de Granada y Universitat de València, 2004. . Para un estado breve de la cuestión ver: HALSALL, G.: Las migraciones bárbaras y el occidente romano, 376568, p. 51 y ss- cap. 14. Un rico debate en: GILlET, A. (ed.): On Barbarian Identity. Critical Approaches to Ethnicity in the Early Middle Ages, Turnhout: Brepols, 2002. POHL, W. Y ReIMITZ, H. (eds.): Strategies of Distinction. The Construction of Ethnic Communities, 300-800. Serie Transformation of the Roman World 2, Leiden: Brill, 1998. GoeTZ, H.W, JARnUT, J. y POHL, W.: Regna and Gentes. The Relationship between Late Antique and Early Medieval Peoples and Kingdoms in the Transformation of the Roman World, Leiden-BostonColonia: Brill, 2003. Para una crítica feroz a Wenkus y Wolfram ver: BowLUS, CH.: "Ethnogenesis: the tyranny of a concept". On Barbarian Identity. Critical Approaches to Ethnicity in the Early Middle Ages, Turnhout: Brepols Publishers, 2002, pp. 241-256.

${ }^{759} L V, 2,5,12$, p. $112 ; 4,2,15-16$, p. 183; 4. 5. 5, p. 201.
} 


\section{4}

\section{Las recompensas como nexo mediador de la relación política}

Hasta ahora observamos que el vínculo existente entre los guerreros y los jefes aristocráticos constituyó una relación de poder y subordinación en constante construcción. El estatus del líder debía ser asegurado, pues si bien era legítimo no era legalmente estable ni heredable. Un medio para lograr su estabilidad era recompensar a sus seguidores con gratificaciones materiales, oportunidades políticas y favores judiciales ${ }^{760}$.

Sostenemos que estas recompensas mediaban la relación política existente entre los guerreros y su líder. Fueron fundamentales porque constituyeron el único beneficio seguro que recibirían los guerreros por sus servicios, pues ya hemos visto que debido a la irregular situación del sistema tributario es impensable el financiamiento sistemático del ejército con recursos provenientes de la recaudación de los impuestos ${ }^{761}$. Consideramos importante añadir la afirmación de Isla Frez sobre la falta de evidencia que demostrase que los reyes viajaban a las expediciones con las monedas suficientes como para enfrentar el pago de los hombres $\operatorname{armados}^{762}$.

Podemos distinguir entre dos tipos de recompensas de naturaleza económica: las formales y las informales. Halsall propone que, como en Francia e Inglaterra, entre los visigodos también se plasmó en su legislación la preocupación de definir qué podían esperar los miembros de la elite de sus seguidores ${ }^{763}$. La misma afirmación puede ser aplicable a las expectativas de los guerreros sobre el comportamiento de sus líderes. Los vínculos clientelares sellados por promesas de fidelidad sancionados por las leyes visto con anterioridad ilustran sobre las recompensas formales. Estas leyes también dictaminaron las ganancias que deberían recibir los hombres libres, que prometieron su fidelidad, por la participación en las incursiones o misiones dirigidas por los aristócratas: tierras, armas,

\footnotetext{
${ }^{760}$ Halsall ya ha señalado que el botín de guerra no fue el único beneficio obtenido de la guerra: títulos, honor y regalos intangibles provenían del favor regio o del patronazgo aristocrático. HALSALL, G.; Warfare and society in the Barbarian West, 450-900, p. 37

${ }^{761}$ Ver capítulo 3 el problema de la recaudación de los impuestos.

762 ISLA FREZ, A.: Ejército, sociedad y política en la Península Ibérica entre los siglos VII y XI..., pp. 99-101.

${ }^{763}$ HALSALL, G.; Warfare and society in the Barbarian West, 450-900, pp. 69 y 70.
} 
bienes muebles e inmuebles. Las implicancias de estas entregas legalmente obtenidas al analizar los vínculos de lealtad ya han sido abordadas.

Una de las leyes que reguló las recompensas económicas formales no tratada en profundidad con anterioridad es la 4, 5, $5^{764}$, cuyo propósito fue reglamentar las ganancias de los hijos con respecto al derecho de los padres sobre ellas. El contenido de la ley genera un debate entre los historiadores, en especial el uso del término leudes porque es peculiar y excepcional, empleado solo en este único texto legal que trata sobre aspectos relacionados con el derecho de familia.

En las primeras líneas, esta ley dictaminó que cualquier joven que contase con sus padres vivos tendría el derecho absoluto sobre sus propiedades conseguidas sive de munificentia regis aut patronorum beneficiis, es decir, tenía la facultad de venderlas o dárselas a quien quisiera, anulando reclamo alguno por parte de sus progenitores. El segundo (y polémico) apartado de la ley indicó que del total de lo conseguido por los leudes (no por beneficio regio, sino por el propio desempeño en una expedición pública) una tercera parte correspondería a sus padres.

Tanto Torres López como Sánchez Albornoz entendieron que la ley regulaba las ganancias obtenidas por jóvenes que aún vivían con sus padres en dos situaciones distintas y concretas: la primera parte trata sobre los bienes dados por un patrón aristocrático, pudiendo ser el mismo rey, en un contexto no bélico, y la segunda sobre las ganancias obtenidas durante una campaña pública. El gran problema radica en cómo interpretar la voz leudes. Sánchez Albornoz prefiere entender que este término (importado por los visigodos desde el reino franco $^{765}$ ) designaba a aquellos que tuvieron un vínculo especial con el rey. En cambio, Torres López - siguiendo su esquema de razonamiento sobre el estado visigodo - sostuvo que los leudes eran todos los súbditos del reino. A esta afirmación Sánchez Albornoz responde que no fue posible que leudes designase a todos los súbditos, pues no fue hasta las leyes de Ervigio que los patrocinados concurrieron a la guerra con los aristócratas. Considera que el

\footnotetext{
${ }^{764} L V$, p. 201 y ss.

${ }^{765}$ El término leudes en el reino franco remite a los seguidores militares de la aristocracia. Dice Wood sobre los leudes francos: "These were military followers apparently of considerable social status and influence, though probably to be distinguished from the greatest magnates of the realm, many of whom had military followings of their own, and might be expected to fight for the king both inside and outside his kingdom", WoOD, I.: The Merovingian Kingdoms 450-751, Routledge, London, 2012, p.64.
} 
servicio de armas era obligatorio y gratuito, por lo tanto, los leudes de la 4, 5, 5 solo fueron aquellos que marchasen a la guerra bajo el estandarte regio, y vio en estos "(...) una prolongación de aquellos jóvenes, que con los comites robustiones formaban el séquito de los príncipes germanos (...)"766.

Otro significado le otorga D’Ors ${ }^{767}$, quien consideró un acierto el argumento que esgrime Torres López. Este defiende que fue incongruente sostener que si los leudes fueron participantes del séquito regio quedasen en inferior condiciones que los que no lo fueron respecto a sus ganancias. También acepta la idea de Sánchez Albornoz cuando sostiene que los leudes no fueron todos los súbditos. Entonces, propone como solución que la voz leudes denominaba a los hombres de condición inferior, igual que en la Lex Burgundionum (leute). Para D’Ors la segunda parte de la ley instituyó

“(...) un régimen para el peculio castrense ordinario, es decir, el de los <soldados>; y se establece una tercia a favor del padre como liquidación de su derecho usufructuario sobre el peculio castrense. Cuando, en cambio, se trata de los servicios militares de los nobles, no hay soldada, sino beneficio regio, y entonces aquel hijo tiene derecho pleno sobre tales donaciones" ${ }^{\prime 768}$.

Años después, Barbero y Vigil estudian esta ley. Según el análisis, los leudes fueron aquellos libres que sin patrón o sin haber recibido el beneficio regio iban a la guerra junto a sus padres, y a cambio de compartir el sustento debieron dar la tercera parte de sus ganancias logradas en las expediciones públicas. Según estos autores, el primer apartado de la ley reforzó los lazos de dependencia, mientras que la segunda "debe ser, sin duda, un arcaísmo germánico con el que se designaría en su tiempo a los hombres de las tribus que, como es sabido, tenían la obligación de ir a la guerra con sus parientes"769. Declaran que esta situación fue muy poco frecuente.

\footnotetext{
766 SÁnchez Albornoz, C.: "Los leudes en la Lex Visigothorum", Revista Chilena de Historia del Derecho, 1961, 2, p.17.

${ }^{767}$ D’ORS, A.: “Los leudes de LV Antiqua 4, 5, 5”, AHDE, XXIV, 1954, p. 638 y ss.

${ }^{768}$ Idem.

${ }^{769}$ BARBero, A. \& VigiL, M.: La formación del feudalismo en la Península Ibérica ..., pp. 43 y 44.
} 
García Moreno también brindó su opinión sobre el problema de los leudes. Entendió que estos deberían ser identificados como

\begin{abstract}
“individuos unidos al rey por una relación o vínculo especial, siendo sobre todo característico el hecho de tratarse de guerreros que reciben a cambio de sus servicios militares una concesión territorial" $" 770$.
\end{abstract}

Considera que la primera parte de la ley tuvo su origen en el derecho romano; aunque la segunda es de más difícil solución. Encuentra elementos similares en la legislación lombarda y bizantina, lo cual le hecha luz ${ }^{771}$.

Observando el abanico de exégesis e hipótesis sobre el término leudes, no hay dudas de que cada autor lo define según su marco interpretativo. Gran parte de la historiografía actual no se hace eco de los problemas debatidos en el siglo XX, tal vez debido al callejón sin salida que genera el término leudes en este contexto.

En nuestra opinión, aceptamos la primera parte de la interpretación de Barbero y Vigil, aquella que dice que los leudes eran jóvenes libres que acudían con sus padres a la guerra. La segunda sección de su interpretación (la poca frecuencia con que sucedía este hecho) es una afirmación realizada sin ningún sustento documental, resultado obtenido a partir del examen general desarrollado por los autores sobre este periodo. Como hemos visto, los hombres libres con lazos clientelares integraban las comitivas armadas desde el siglo IV, y no debería extrañarnos que llevasen a sus hijos en edad de combatir. Entendida de esta forma, se comprendería la posición desfavorable en la cual quedaban estos leudes. Finalmente, a nuestro parecer, la importancia de esta ley antigua fue que garantizaba que lo adquirido en las campañas se lograba a título individual, lo cual permitió una acumulación y un posible ascenso social. Asimismo, advertimos que los grupos que concurrían a las expediciones bélicas lo harían cohesionados por relaciones de fidelidad y también de parentesco.

Otras leyes regulaban también las recompensas debidas a aquellos hombres que iniciaban una misión de rescate en un contexto de guerra. La ley 9, 2, 7 "Quam mercedem

\footnotetext{
${ }^{770}$ García Moreno, L. A: "Estudios sobre la organización administrativa del Reino de Toledo", Anuario de Historia del Derecho Español, XLIV, 1974, pp 5-155.

${ }^{771}$ Ibidem, p. 107-109.
} 
accipiat qui mancipia vel quaslibet res de manu hostis excusserit" 772 indicaba que aquellos, durante un ataque desesperado (desperans) contra los enemigos, que rescataran dinero, mancipia, u otros bienes serían recompensados por el dueño — quien reclamaría y certificaría esos bienes como de su legítima propiedad - con la tercera parte del total del valor "pro laboris sui premio consequatur”. También, si alguno convenciese a un siervo de escapar del enemigo brindándole "patrocinium aut consilium", y como consecuencia lograse que el siervo regresase con su dueño original, recibiría como recompensa la décima parte del valor del siervo devuelto.

No debería ser extraña la existencia de regulaciones legales sobre las recompensas obtenidas por llevar a cabo misiones de rescate. Estas actividades debieron ser bastantes frecuentes, así como las escaramuzas que tenían como objetivo el pillaje y la búsqueda del botín. Recordemos que Égica eximía del cumplimiento del deber militar a aquellos libertos que habían sido enviados a misiones especiales; esta consideración en una ley de alcance general apunta a pensar que estas misiones tendrían una frecuencia muy alta.

Además de las ganancias legales que los guerreros esperaban recibir, durante las campañas los hombres conseguirían bienes por vías no formalizadas por la ley, pero aun así consideradas legítimas, hacemos referencia al botín de guerra ${ }^{773}$.

Isidoro de Sevilla define el término botín (spolia) (entrada ocho, capítulo II $<D e$ Triumphis $>$, libro XVIII "De bello et ludus"774) de la siguiente manera:

"Spolia hostium: praeda, manubiae, exuviae, partes. Praeda a praedando vocata. Manubiae, eo quod manibus detrahuntur. Haec et exuviae ab exuendo dictae, quia exunntur. Haec et partes a pari divisione pro personarum qualitate, et laborum iusta decisione. Spolia autem a palleis, quasi expallia; victis enim detrahuntur."

Según Isidoro, el botín estuvo constituido por aquellos bienes de los derrotados en la guerra que los vencedores podrían llevarse en las manos. Se debería dividir en partes iguales y de acuerdo con las cualidades de las personas y el trabajo realizado. El reparto, entonces,

\footnotetext{
${ }^{772}$ LV , p. 370.

${ }^{773}$ En el capítulo 3, sobre las bases materiales de los reyes, hemos tratado el problema de la rapiña y el botín como una de las vías de obtención de recursos económicos.

${ }^{774}$ ISID. Etymologiae, p. 1220.
} 
respetaba una estructura jerárquica. Esta definición ideal se aleja un poco —a veces demasiado - de las descripciones halladas en otras fuentes. Sin embargo, lo interesante de la entrada spolia no es la etimología en sí, sino el lugar que ocupa en el conjunto de la obra: se encuentra en el capítulo cuyas definiciones constituyeron todos los elementos que se consideraban parte del triunfo bélico. Ahora bien, la definición que Isidoro propuso permite solo un primer acercamiento al proceso de la toma del botín y sus múltiples dimensiones de análisis.

La definición sostenida por Isidoro deja ver que el botín constituía una forma legítima e inmediata de apropiación de los recursos económicos por la aristocracia en los momentos de guerra. El rey, cuando era el líder del ejército vencedor, se apropiaba del total del botín convirtiéndolo en parte del tesoro ${ }^{775}$. Bajo control regio quedaban los caballos, la hacienda, el oro, la plata, los objetos valiosos y los hombres tomados como rehenes. En las distintas crónicas visigodas y en las provenientes de otros reinos, las menciones sobre los saqueos son muchísimas ${ }^{776}$, y allí observamos, como ya hemos indicado en el capítulo tres, que los reyes con el botín de guerra engrosaban el tesoro regio, así como lo repartían como recompensa entre los guerreros y lo entregaban como regalo en el momento de sellar alianzas políticas. Como ya hemos apuntado, el saqueo constituía una vía importante de enriquecimiento. Sin embargo, no era una vía segura de acumulación, pues el reparto de los bienes capturados era la práctica que sucedía al triunfo bélico. Los bienes obtenidos solo estaban en manos regias de forma temporal.

De estos tres aspectos, en este capítulo resaltamos el reparto del botín que realizaba el rey entre sus guerreros. Si bien las fuentes no brindan descripciones minuciosas sobre el mismo - abundan las referencias sobre la toma del botín, mas no tanto sobre el reparto, por lo cual recurrimos a testimonios de regiones ajenas al control visigodo-, inferimos que una vez finalizada una batalla (pero no la campaña) con una victoria importante, el rey repartía el botín entre sus guerreros a modo de recompensa.

El mejor ejemplo documentado del reino visigodo que ilustra lo antedicho proviene de la pluma de Julián de Toledo. En una sección del capítulo XI relató que Wamba — tras la toma de las ciudades de Barcelona y Gerona controladas por el rebelde Paulo— avanzó sobre

\footnotetext{
775 DuBY, G.: Guerreros y campesinos... p. 68 .

776 Ver capítulo 3 sobre las bases materiales de los reyes visigodos.
} 
los Pirineos, donde descansó junto a su ejército por dos días. Al tercer día, atacó los castra llamados Caucoliberi, Vulturaria y Castrum Libiae, y triunfó. Conquistó un copioso botín de oro y plata que repartió entre los hombres de su ejército ${ }^{777}$.

En un pasaje de la Historia de los Longobardos de Pablo Diácono existe una narración similar a la detallada. Entre los años 491 y 510, se desarrolló una guerra entre los hérulos, bajo comandancia de su rey Rodolfo, y los longobardos dirigidos por Tatón. Luego de la batalla final, el autor relata que después de la victoria los longobardos tomaron el botín que encontraron en el asentamiento enemigo y lo repartieron entre ellos ${ }^{778}$.

Procopio de Cesárea brinda dos ejemplos muy interesantes sobre esta práctica. El primero que destacamos es un intercambio de cartas entre el emperador Justiniano y Amalasunta que el historiador recoge en su obra. El bizantino reclamó a la reina regente de los ostrogodos que restituyera la fortaleza de Lilibeo tomada por su gente, y le retornase unos esclavos prófugos. Además, le reprochó que la ciudad de Graciana se vio afectada y que de manera pronta ordenara estos inconvenientes causados. Amalasunta le respondió la carta con una serie de reproches y con un tono imperioso. En relación con Lilibeo, le contestó que pertenecía a su gente desde hacía mucho tiempo; y que por diez esclavos y una ciudad amiga, ultrajada por error de unos soldados que perseguían a los enemigos, no valía la actuación de Justiniano que hacía peligrar la alianza política entre ellos establecida. A modo de advertencia, le recordó que fueron ellos quienes le proporcionaron lo que necesitaban para enfrentarse a los vándalos, incluyendo los caballos (que fueron decisivos para la victoria), y que les permitieron atracar sus barcos en la Península Itálica para abastecerse de provisiones para seguir hasta Libia. Por estos motivos le recordó que ella y su gente constituyeron la pieza clave de la victoria de Justiniano. Y agregó que dando su ayuda se vieron perjudicados porque “ “...) en el reparto del botín no han conseguido la parte de este que nos correspondía según dicta la costumbre de la guerra (...)”779. De este intercambio de correspondencia, de

\footnotetext{
${ }^{777}$ IUL. TOL. HW, p. 227: “Egressus igitur post haec princeps de ciuitate Gerunda, belligerosis incursibus gradiens, ad Pirinei montis iuga peruenit. Vbi duobus diebus exercitu repausato, per tres, ut dictum est, diuisiones exercitus Pirinei montis dorsa ordinauit castraque Pirenaica, quae uocantur Caucoliberi, Vulturaria et Castrum Libiae, mirabili uictoriae triumpho cepit atque perdomuit, multa in his castris auri argentique inueniens, quae copiosis exercitibus in praedam cessit".

${ }^{778}$ PAULI DiACONI, HL, p. 59 "Tunc Langobardi, patrata victoria, ingentem, quam in castris reppererant, inter se praedam dividunt".

${ }^{779}$ Procopio de CeSAREa: De bello Gothico, p. 65.
} 
lo más interesante, destacamos que la aristocracia consideraba como parte de la lógica de la guerra la entrega justa de la parte del botín.

El segundo episodio tomado de las historias de Procopio tiene lugar en uno de los enfrentamientos protagonizados por los romanos y los ostrogodos en el año 538. El comandante Belisario envío a su subalterno, Juan, a saquear el Piceno. Este marchó con la misión de reducir a la condición de esclavos a los hombres enemigos que derrotara e incautar todo lo que encontrara. Además, le advirtió que debía procurar que el botín quedase intacto para repartirlo “(...) justa y equitativamente entre todo el ejército”. Y a continuación, según Procopio, Belisario de forma jocosa agregó: "Pues no es justo que los zánganos sean destrozados con gran esfuerzo por unos y que otros, por su parte, sin haber soportado penalidad alguna, disfruten de la miel"780.

Un último ejemplo. Gregorio de Tours relata el famoso ${ }^{781}$ episodio protagonizado por el rey Clodoveo. Durante la campaña del año 486, el ejército franco capturó objetos de distintas iglesias que pasaron a formar parte de un copioso botín, y entre ellos se encontraba un hermoso vaso sagrado. El obispo Remi de Reims le pidió, a través de un mensajero, que ese vaso le fuera devuelto. El rey solicitó al mensajero que lo acompañase a Soissons, y le aseguró que si ese vaso le tocaba en el reparto del botín, se lo entregaría para que se lo hiciese llegar al obispo ("Sequere nos usque Sexonas, quia ibi cuncta que adquisita sunt dividenda erunt. Cumque mihi vas illud sors dederit, quae papa poscit adimpleam "782). Cuando llegó el momento del reparto, Clodoveo pidió a sus guerreros que, además de su porción, el vaso en cuestión le fuera otorgado ("Rogo vos, o fortissimi proeliatores, ut saltim mihi vas istud extra partem concidere non abnuatis" ${ }^{, 783}$ ). Los guerreros reunidos le concedieron su deseo, argumentando que estaban bajo su dominio ("tuo sumus dominio subiugati",784) y que nadie podía resistir su poder ( "nullus enim potestati tuae resistere valet"785). Sin embargo, uno de los reunidos estuvo en desacuerdo y lo demostró golpeando con su hacha de doble filo al

\footnotetext{
${ }^{780}$ Ibidem, p. 262.

781 Este episodio, relacionado directamente con la conversión de Clodoveo al cristianismo, es tomado como acto fundacional de Francia. VILAR, P.: Pensar históricamente. Reflexiones y recuerdos, Barcelona: Crítica, 2004, p. 23, nota 8.

${ }^{782}$ GREG. TUR. Hist. Franc. p. 72

${ }^{783}$ Idem.

${ }^{784}$ Idem.

${ }^{785}$ Idem.
} 
vaso y diciendo: "Nada tomes sino lo que la suerte verdadera (¿o el reparto verdadero? $\left.{ }^{786}\right)$ te conceda" ("Nihil hinc accipies, nisi quar tibi sors vera largitur" "787). El vaso se rompió, y Clodoveo no olvidó semejante afrenta. Un año después, hizo reunir a sus guerreros y pasó revista a sus equipamientos. Frenó ante el guerrero que había golpeado el vaso, y lo reprendió a causa del estado de sus armas; además, le dijo que le eran inútiles. Tomó un hacha del guerrero y la arrojó al suelo, cuando aquel se inclinó para recogerla, el rey franco incrustó su arma en la cabeza del guerrero y dijo: "Sic, tu Sexonas in urceo illo fecisti",788

No localizamos otras menciones en la documentación alusiva a Europa meridional y franca tan explícitas sobre el acto de reparto ${ }^{789}$. Las menciones sobre botines de guerras solo remiten a las capturas de los bienes o saqueos a la cuales fueron sometidas las regiones afectadas. Tal vez se debió a que la entrega del botín era un acto sumamente gestual y, por lo tanto, no era necesario registrarlo en las crónicas escritas. A pesar de esta escueta información proporcionada por las fuentes, observamos que la generosidad en la entrega y la promesa del botín fueron medios por los cuales el líder aristocrático se aseguraba la lealtad de los guerreros, cohesionaba los lazos entre los hombres libres y era una forma de demostrar su capacidad para dirigir de forma exitosa una campaña. Los hombres esperaban su parte, era un acuerdo tácito que cada uno recibía lo suyo según su posición social y su rol en la batalla ${ }^{790}$.

No solo las recompensas materiales eran concedidas a los guerreros, también las recompensas no materiales tenían un gran valor y eran esperadas.

En las asambleas judiciales el apoyo que otorgaba la aristocracia a sus hombres visibilizaba su vínculo y daba un claro mensaje de cohesión grupal al resto de los presentes

\footnotetext{
${ }^{786}$ Es interesante que el término sors, traducido por la mayoría de los estudiosos de la obra de Gregorio como suerte, también puede ser traducido como reparto, más teniendo en consideración el uso del término en el reparto de las tierras. Sobre esto último ver: GARCía MorenO, L. A.: "El término sor y relacionados en el Liber Iudicum: de nuevo el problema de la división de las tierras entre godos y provinciales", Anuario de historia del derecho español, 1983, 53, p. 138-177.

787 Ibidem.

${ }^{788}$ Idem, p. 73.

${ }^{789}$ En la documentación proveniente de Europa del Norte son mucho más abundantes las descripciones sobre el reparto del botín.

790 Existe una amplia bibliografía sobre la entrega de parte del botín como recompensa a los guerreros. Remitimos a HALSALl, G.: Warfare and society in the Barbarian West, 450-900, p. 36 y p. 135; SARRIS, P.: Empires of Faith: The Fall of Rome to the Rise of Islam, 500-700, Oxford: Oxford University Press, 2011, p. 121.
} 
en el pleito. Estas prácticas son denunciadas por ciertas leyes como inadecuadas e ilegales. Las distintas revisiones del compendio legal del siglo VII mantuvieron dichas leyes, dándonos una clara razón para pensar que esos comportamientos aristocráticos se repetían con gran frecuencia.

En su extenso y erudito estudio sobre el funcionamiento de las instituciones judiciales visigodas, King indica que por la oscuridad de las leyes es muy difícil interpretar los testimonios sobre el carácter público de los procesos judiciales ${ }^{791}$. Sabemos que en el recinto se encontraban presentes los interesados, los testigos, el juez y sus colaboradores y a veces parte del público. Seguramente que entre el público se encontrase el aristócrata que tendría interés en defender a su patrocinado en la causa que se viera involucrado. La ley 2, 2, $8^{792}$ dispune que el juez multaría con dos libras de oro y expulsaría por la fuerza del pleito a aquellos grandes que intermediasen de forma incesante a favor de sus patrocinados. También los grandes interferían en las declaraciones de los testigos para que el juez no pudiera comprobar su validez ${ }^{793}$; y muchos jueces se verían inclinados a dictar su sentencia bajo la presión y los regalos que obtendrían de los poderosos o amistades ${ }^{794}$

El análisis que hemos hecho de las fuentes sobre el problema planteado muestra que el ejército visigodo no funcionó como una institución, no tuvo una estructura organizativa rígida que pudiese ser plasmada en un organigrama; esto no ocurrió en ningún momento del reino visigodo de Toledo. De hecho, los cargos nombrados en las leyes fueron polifuncionales - como el caso de los condes - o derivados de cargos honoríficos — como los gardingos-.

Consideramos que el ejército estuvo compuesto por múltiples células dirigidas por un líder miembro de la aristocracia al que le rendían lealtad. La evidencia legal del siglo VII da cuenta más de una necesidad regia de disciplinar a la arisca aristocracia que de organizar funcionalmente un cuerpo militar. El modo de reclutar y dirigir las unidades de combate por parte de la aristocracia imposibilitó la formación de un cuerpo militar orgánico que respondiese a una sola voz.

\footnotetext{
${ }^{791}$ KING, P.D.: Derecho y sociedad en el reino visigodo ..., p. 121.

${ }^{792} \mathrm{LV}, 2,2.8$, "De his, qui in causis alienis patrocinare presumserint", p. 84; 2, 2, 2 "Ut nullo audientia clamorea ut tumultu turbtur”, pp. 80 y 81.

${ }^{793}$ Ibidem, 7, 1, 1, “De indice et hec, que indicare dicuntur”, p. 286.

794 Ibidem, 7, 4, 6, "De damno iudicis criminosum indebite absolventis"; 6, 4, 3 "De reddendo talione et conpositionis suman pro non reddendo”, pp. 264-266.
} 
Las unidades de combate formadas por sujetos de distintas condiciones sociales y jurídicas, a pesar de las diferencias de clase, estuvieron cohesionadas socialmente a través de la entrega de recompensas y el juramento de fidelidad. Entre ellos se forjaba una relación política que estaba mediada por recompensas, tomando una forma similar a la relación reyaristócrata analizada en el capítulo anterior. Sin embargo, estos grupos no fueron ajenos al conflicto, al disenso o a las contradicciones internas ${ }^{795}$. La fidelidad prometida no garantizaba que los guerreros libres siguieran a sus líderes hasta el final de la empresa. De hecho, fueron proclives a abandonar a su patrón/líder si este no cumplía con su parte o fallaba de alguna manera, también, si sospechaban que la retribución económica debida y prometida corría peligro. Los hombres libres y los clientes rompían lazos de fidelidad, interrumpían los vínculos de subordinación por la violencia, traición, abandono o de común acuerdo.

La atomización de los grupos de guerreros fue la característica central del ejército visigodo, y el comportamiento de las tropas jugó un papel fundamental en las luchas por la hegemonía política. A pesar de esto, la posibilidad de la unión de huestes de diferentes jefes bajo el mando de un solo líder para una campaña militar particular existió. ¿Cómo podían, entonces, los reyes cohesionar en un solo ejército a múltiples jefaturas? ¿Cómo pudieron los reyes convertirse en los jefes de los ingenuos y legitimarse frente a la aristocracia? Una parte de la respuesta ya ha sido formulada en las páginas anteriores. La entrega de recompensas fue una vía principal, mas no la única. Las prácticas discursivas también tuvieron su rol preponderante. En el siguiente capítulo seguiremos contestando las preguntas que abrimos con el desarrollo del problema sobre la construcción permanente de la autoridad y legitimación regia.

\footnotetext{
${ }^{795}$ Una reflexión sobre este concepto en la Temprana Edad Media en: POLH, W.: "Social Cohesion, Breaks, and Transformations in Italy, 535-600”, en BALZARETTI, R., BARROW, J. AND SKINNER, P. (eds): Italy and Early Medieval Europe: Papers for Chris Wickham, Oxford, 2018.
} 


\section{CAPÍtulo 7}

\section{REYES GUERREROS, REYES LEGÍTIMOS}

En los capítulos anteriores hemos argumentado que el sistema sociopolítico del reino visigodo de Toledo tuvo un carácter inestable. Sugerir lo dicho no equivale considerar que los reyes fueron incapaces de gobernar de forma exitosa y/o que no contaron con el beneplácito de la aristocracia. Proponemos que sostener la posición política significaba construir permanentemente la autoridad, tarea ardua porque la fidelidad política tuvo un carácter condicional.

La dominación política regia descansaba sobre una red de lazos de fidelidad que se estrechaban con la entrega de recompensas. Sin embargo, como ya hemos visto, existía la posibilidad de retirar la lealtad y romper los lazos, y nunca faltaba un aristócrata dispuesto a competir por el puesto regio. Es más, muchos de ellos contaban con fortunas personales, apoyo social y un gran prestigio que les permitieron obrarse una reputación en la corte de Toledo tan digna como para candidatearse como reyes. Entonces, en un sistema sociopolítico 
inestable, quien reinaba no tenía más remedio que exhibirse impávidamente como el mejor candidato, obligado a cumplir con las expectativas y necesidades aristocráticas. En este contexto, los ritos y los discursos ideológicos se constituyeron como factores edificantes de la autoridad regia.

Por lo expuesto, trabajaremos sobre el aparato ideológico que justificaba la posición privilegiada de los reyes. Aquí no tendrá lugar el análisis del ejercicio de las funciones gubernamentales regias como una vía de construcción de la autoridad, pues ya han sido trabajadas en otras partes de nuestra tesis. Otra razón — no menor a la anterior que refuerza nuestra negativa - se funda en que muchos autores ya han demostrado que los reyes validaban sus cargos a través del ejercicio de dichas funciones, como ser: la promulgación de las leyes, la organización administrativa y fiscal (incluyendo la acuñación de monedas) y la dirección del ejército. Vale remitir al respecto a Valverde Castro ${ }^{796}$. Nuestro propósito consiste en observar dimensiones de la práctica política menos exploradas.

\section{1}

\section{La ideología legitimante del poder regio}

McKitterick sostiene, desde una visión general de la historia de la Alta Edad Media (argumento que es repetido por varios autores ${ }^{797}$ ), que los reyes cultivaron un estrecho vínculo con la Iglesia, imitando a los emperadores romanos. Dios convalidaba su autoridad, y estos debían procurar la salvación del reino, es decir:

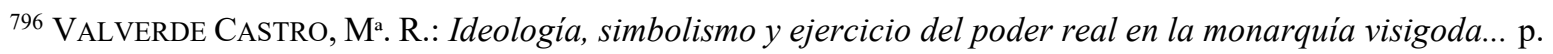
225.

${ }^{797}$ Un recuento bibliográfico sobre esto en: LANSING, C. Y ENGLISH, E.D. (eds): A companion to the medieval world, vol. 16, John Wiley \& Sons, 2012, cap. 3. Ver también: FOURACRE, P.: "Introduction: the history of Europe, 500-700", "Francia in the seventh century", en FOURACRE, P. ET AL. (ed.): The new Cambridge medieval history, Cambridge: Cambridge University Press, 2005.
} 
“(...) La preocupación por el bienestar moral de los individuos, por las formas correctas de culto, por el pensamiento y la devoción, y la promoción de la educación y la enseñanza para animar el pensamiento correcto y el entendimiento de la fe cristiana (...)"798

Asimismo, la autora reconoce que en toda Europa occidental el elemento guerrero fue fundamental en el ejercicio del poder. Estos dos elementos constituyeron parte fundamental del programa ideológico de la realeza.

Para el ámbito visigodo, García Moreno propone que la sacralización de la figura regia comenzó con Recaredo, quien, además de imitar modelos bizantinos 799 , “se atribuyó funciones apostólicas, que en cierta medida le situaban por encima de la misma Iglesia" ${ }^{\$ 800}$. No obstante, la seguidilla de figuras débiles hizo que la realeza evolucionara "en un sentido mucho más teocrático y subordinacionista de la Monarquía con respecto a la Iglesia" ${ }^{801}$. Es decir, entre las intenciones cesaropapistas de Recaredo y las teocráticas de la Iglesia los reyes se vieron derrotados por la corporación eclesiástica, que impuso un discurso de poder teocrático.

Esta tradición historiográfica es cuestionada por algunos autores que discuten el grado de implementación y aceptación del discurso sobre la sacralización de los reyes. Valverde Castro considera que los principios teocráticos expuestos tendieron a fortalecer al poder regio, mas la dinámica política imposibilitó el pleno ejercicio del poder que la ideología confería $^{802}$. En el mismo sentido, Velázquez, Barroso y Morin de Pablos observan que los

\footnotetext{
798 MCKITTERICK, R.: La alta Edad Media. Europa 400-1000..., p. 41.

${ }^{799}$ Sobre la adopción de los símbolos bizantinos ver: DÍAZ P. y VALVERDE M.R: "The theoretical strength and practical weakness of the visgothic monarchy of Toledo", p. 181. GARCÍA MORENO, L.A.: Leovigildo: unidad y diversidad de un reinado ..., p. 90 y ss. ARCE, J.: "Ceremonial visigodo/ <bizantino>. Un tópico historiográfico", en PÉREZ MARTín, I. Y BÁdENAS DE LA PeÑA, P. (eds.): Bizancio y la Península Ibérica. De la antigüedad tardía a la edad moderna, Madrid: Nueva Roma 24, 2004, pp. 101-115. KocH, M.: "La imperialización del Reino visigodo bajo Leovigildo: ¿es la "imitatio imperii" de Leovigildo la manifestación de un momento de cambio en la pretensión de poder y la ideología visigoda?". PÉREZ SÁNCHEZ, D.: "La idea del $<$ buen gobierno> y las virtudes de los monarcas del reino visigodo de Toledo", Mainake, XXXI, 2009, pp. 217227.

${ }^{800}$ GARCía MoRenO, L.A.: Historia de la España visigoda ..., p. 324.

${ }^{801}$ Idem.

${ }^{802}$ VALVERDE CASTRO, M ${ }^{\text {a }}$. R.: Ideología, simbolismo y ejercicio del poder real en la monarquía visigoda... $\mathrm{p}$. 255 y 274. Los argumentos en torno a esta afirmación se desarrollaron en el capítulo primero de esta
} 
reyes visigodos fueron exaltados a través de las insignias imperiales y presentados ante el pueblo como justos y píos, dignos defensores del pueblo y de la Iglesia. Sin embargo, los ritos provenientes del seno eclesiástico, incluyendo entre ellos a la unción regia y al juramento de fidelidad, quedaron reducidos al ámbito de lo simbólico por el uso que se hizo de ellos en las distintas situaciones políticas. Los autores comprenden que la consagración de los reyes "tiranos" a través de aquellos ritos hizo que este sistema ideológico perdiera su potencial como elemento estabilizador del reino ${ }^{803}$.

Por su parte, Stocking plantea que en los Concilios (a partir del año 589) han quedado registrados los intensos debates desarrollados entre la jerarquía de la Iglesia y el poder secular sobre el alcance de la jurisdicción conciliar y el alcance de la autoridad laica y de la eclesiástica. Generaciones enteras de obispos aspiraron a lograr un consenso sobre el orden cristiano como ideología de la unidad política-religiosa del reino. Sin embargo, las tensiones y conflictos entre los reyes y los eclesiásticos impidieron que el programa planeado se ejecutase. Además, fue prácticamente inaplicable por su alto grado de idealismo y las contradicciones existentes entre la solidaridad de la elite y los intereses locales. ${ }^{804}$.

Sin embargo, nos preguntamos: ¿Existió algún tipo de correspondencia entre las representaciones ideales de los reyes y las relaciones sociales establecidas entre los reyes y la aristocracia? ¿El sistema ideológico careció de fuerza, se suscribió solo al ámbito de lo simbólico? Estas son algunas de las preguntas que resolveremos en este capítulo. Para ello, luego del somero repaso historiográfico hecho, trabajaremos sobre el programa ideológico proveniente de la Iglesia y sus problemas de implementación. En un segundo momento, analizaremos la importancia de la identidad aristocrática laica y cómo el ethos guerrero fue un componente central del discurso que sustentaba al poder regio.

investigación. También ver las referencias de las obras de Díaz Martínez, quien sostiene una postura similar. En el mismo sentido: PÉREZ SÁnCHEZ, D.: "La idea del < buen gobierno> y las virtudes de los monarcas del reino visigodo de Toledo".

${ }^{803}$ Barroso Cabrera, R., Morín de Pablos, J. y Velázquez Soriano, I.: "La imagen de la realeza en el reino visigodo de Toledo a través de la iconografía y la epigrafía”, p. 503.

${ }^{804}$ StockING, R.: Bishops, councils, and consensus in the Visigothic Kingdom, 589-633, Michigan: The University of Michigan Press, Michigan, 2003. En especial la Introducción y p. 143 y ss. 


\section{La figura del princeps diseñado por la inteligencia católica}

Isidoro de Sevilla y Julián de Toledo fueron dos figuras que presidieron reuniones conciliares de gran importancia para el desarrollo de la política del reino ${ }^{805} \mathrm{y}$, a su vez, dejaron por escrito sus concepciones sobre la naturaleza del poder regio ${ }^{806}$.

Isidoro leyó las escrituras sagradas en una clave que le permitió elaborar un sistema de creencias compuesto de prácticas morales y valores cristianos, que tuvo como fin enmarcar las conductas de los reyes ${ }^{807}$. Los especialistas señalan que las descripciones isidorianas sobre las personalidades y conductas de los reyes constituyeron modelos para los futuros gobernantes. Asimismo, sus escritos también fueron vectores por los cuales Isidoro intervino en la política secular del reino ${ }^{808}$. Según Reydellet, a partir de la caracterización de

\footnotetext{
${ }^{805}$ Isidoro presidió el II Concilio provincial de Sevilla (619) y el IV Concilio de Toledo (633) y Julián participó en el XII Concilio de Toledo y firmó en primer lugar los Concilios XIII, XIIV y XV. La influencia de Isidoro como político e intelectual es indiscutible. Sobre la figura de Isidoro ver: FONTAINE, J.: Isidoro de Sevilla: Génesis y originalidad de la cultura hispánica en tiempo de los visigodos...; REYDELLET, M.: "Les intentions idéologiques et politiques dans la Chronique d'Isidore de Séville", Mélanges d'archéologie et d'histoire, 82. 1, pp. 363-400. WoOD, J.: The Politics of Identity in Visigothic Spain: religion and power in the histories of Isidor of Seville, Leiden, Brill, 2012.

Sobre Julián: Domínguez Del VAL, U.: Historia de la antigua literatura latina hispano-cristiana, vol. 4, Madrid: Fundación Universitaria Española, 1998, pp. 389-412. RIVERA RECIO, J. F.: San Julián, arzobispo de Toledo (s. VII). Época y personalidad, Barcelona: Editorial Amaltea, 1944. Un listado completo de las obras de estos dos autores y la bibliografía específica en: CODOÑER, C. (coord.): La Hispania visigótica y mozárabe: dos épocas en su literatura, pp. 139-172.

${ }^{806}$ Valerio del Bierzo también escribió sobre el poder de los reyes. Ver en especial FriGHETTO, R.: "O soberano ideal na obra de Valério do Bierzo", Gerión, n 16, 1998, pp. 461-470;

${ }^{807}$ REYDELlet, M.: La royauté dans la littérature latine de Sidoine Apollinaire à Isidore de Séville, Roma: École Française de Rome, 1981, p. 530. Artículos clásicos sobre el tema: ROMERO, J.L.: "San Isidoro de Sevilla. Su pensamiento histórico político y sus relaciones con la historia visigoda", Cuaderno de Historia de España, VIII, 1947; BARBERO, A.: "El pensamiento político visigodo y las primeras unciones regias en la Europa medieval", Hispania,115, 1970; CAZIER, P.: "Les Sentences d'Isidore de Séville et le IV Concile de Tolède. Réflexions sur les rapports entre l'Eglise et le pouvoi rpolitique en Espagne au tour des années 630", Los visigodos. Historia y civilización. Antigüedad y Cristianismo 3, Murcia, 1986.

Para un estado de la cuestión y un recuento de la bibliografía sobre este problema ver: CASTRO, D.: "Modelos bíblicos para reyes visigodos: un estudio a partir de las Sentencias de Isidoro de Sevilla”, Espacio, Tiempo y Forma, Serie III Historia Medieval, 28, 2015, pp. 255-273.

${ }^{808}$ A su vez se considera que Isidoro buscaba la salvación del pueblo visigodo estimulando un comportamiento adecuado según los parámetros católicos. Para un análisis actualizado de este problema ver: WoOD, J.: The Politics of Identity in Visigothic Spain: religion and power in the histories of Isidor of Seville... Conclusions. CASTRO, D.: Palabras inmortales: poder, autoridad y exégesis biblica en el reino visigodo de Toledo (589711), Tesis doctoral, 2017. Por estos motivos que fue conocido como el "tutor del reino". FonTAINE, J.: Isidoro de Sevilla: Génesis y originalidad de la cultura hispánica en tiempo de los visigodos... p. 99 y ss.
} 
Recaredo: "On assiste à une transformation des critères et du vocabulaire politiques. La royauté chrétienne est née ${ }^{\text {" } 09}$.Con respecto a la influencia de Isidoro, Castro observa que

"Al hacer uso de los reyes bíblicos como ejemplos para los reyes visigodos, Isidoro hace de la figura monárquica, en primer lugar, una institución que hunde sus raíces en el pasado veterotestamentario, otorgándole así antigüedad bíblica como principal fundamento. En segundo lugar, hace del buen rey una figura caracterizada principalmente por su obediencia a Dios, buscando hacer prevalecer, más que la capacidad de liderazgo o el desempeño bélico, los distintivos morales, pilares de la tradición cristiana." ${ }^{810}$

Otros autores con anterioridad han opinado de la misma manera ${ }^{811}$. Valverde Castro plantea que el aparato de la inteligencia católica, con Isidoro como protagonista, otorgó al monarca una sólida base conceptual - fundada sobre todo en el carácter religioso pastoral del cargo regio- para el ejercicio de su poder político ${ }^{812}$. Por su parte, Jamie Wood enfatiza que Isidoro a través de sus narrativas históricas tuvo la intención de dotar de una unidad y coherencia a la elite dirigente a través del discurso, influenciar en el presente a través de la percepción del pasado. Según este autor, Isidoro pensaba que solo a partir del dominio

\footnotetext{
${ }^{809}$ REYDELLET, M.: La royautédans la littérature latine de Sidoine Apollinaire à Isidore de Séville...p. 543. ${ }^{810}$ CASTRO, D.: Palabras inmortales: poder, autoridad y exégesis bíblica en el reino visigodo de Toledo (589711) ..., p. 251.

${ }^{811}$ Entre ellos: SALVADOR RUS, R.: "Unidad y paz en el reino visigodo. Dos aspectos del pensamiento político de Isidoro de Sevilla", Antiquité Tardive, 23, 2015. El autor entiende que Isidoro consideraba que "la soberanía no es delegada, sino independiente de cualquier poder temporal y está ligada tiene como misión combatir la impiedad, la injusticia, la división social y política y el pecado, defender y extender la fe de la Iglesia, proteger a sus súbditos y mantener y, si es posible, engrandecer el territorio del reino. La justificación de dignidad real y su desempeño por parte del monarca están en el cumplimiento de estos fines y obligaciones. Si el rey no cumple o se desentiende de ellos, puede ser despojado de forma justa de la dignidad real y, por tanto, perderá su dominio sobre el territorio y los súbditos.", p. 91. Guiance ha analizado las hagiografías provenientes del reino visigodo para observar parte de las caracterizaciones que realizó los miembros de la Iglesia sobre la realeza. Como resultado, no siempre fue valorada de forma positiva. GUIANCE, A.: "De reyes y santos: las manifestaciones de la monarquía en la hagiografía castellana (siglos VII-XI), Acta historica et archaeologica mediaevalia, 22, 2001, pp. 9-30.

${ }^{812}$ VAlverde CAStro, Ma. R.: Ideología, simbolismo y ejercicio del poder real en la monarquía visigoda... pp. 200 y ss.
} 
visigodo sobre la Península Ibérica la sociedad podría desarrollarse y, a la vez, se obtendría la salvación divina ${ }^{813}$.

Isidoro en su Historia Gothorum, alabó a Recaredo por su religiosidad, su piedad y por su inclinación hacia la paz ${ }^{814}$, mas no omitió narrar los triunfos bélicos que cosechó ni olvidó destacar sus cualidades como guerrero y estratega ${ }^{815}$. Reydellet señala que Isidoro retrató a Recaredo considerando su concepción sobre el rey bíblico David ${ }^{816}$, la cual plasmó en De ortu et obitu Patrum. Allí exaltó su excepcional carácter guerrero, sus gloriosos triunfos, su paciencia, misericordia y virtuosidad. ${ }^{817}$. En la descripción de Recaredo existe una conexión entre su fervorosa condición religiosa y su éxito militar; esta correlación se repite en los relatos correspondientes a los demás reyes, tal vez con excepción de Leovigildo ${ }^{818}$. Según Isidoro, Witerico fue hábil con las armas, pero desconoció la victoria. Su comportamiento es catalogado de ilícito ${ }^{819}$. Sisebuto - con quien Isidoro mantuvo una

${ }^{813}$ WoOD, J.: The Politics of Identity in Visigothic Spain: religion and power in the histories of Isidor of Seville... pp. 134 y ss. Ver sobre este tema también: DELL' ELICINE, E.: "Si queremos evitar la ira divina: Impacto y vicisitudes del proyecto eclesiológico de Isidoro de Sevilla (c. 630- 690)", Espacio, Tiempo y Forma, Serie III, $H^{\circ}$ Medieval, 24, 2011, pp. 69-90.

${ }^{814}$ Isidoro con el fin de enaltecer las cualidades de Recaredo realizó una comparación con Leovigildo, quien no resultó favorecido. ISID. Hist. Goth., p. 260: “(...) cultu praeditus religionis et paternis moribus longe dissimiles: namque ille inreligiosus et bello promptissimus, hic fide pius et pace praeclarus, ille armorum artibus gentis imperium dilatans, hic gloriosius eandem gentem fidei trophaeo sublimans".

815 ISID. Hist. Goth., pp. 262 y 264: "In belli quoque gloria satis clarus ac praecipuus extitit".

${ }^{816}$ REYDELlet, M.: La royauté dans la littérature latine de Sidoine Apollinaire à Isidore de Séville...p. 535

${ }^{817}$ ISID. De ortu et obitu Patrum, cap XXXIII: “David, rex idem atque propheta, ortus de genere Juda, lilius Jesse, natus in Betlhlebem, puer pastor ouium inter fratres aetate minor, uirtute praestantior, a Domino in regnum uocatus, a propheta in regem unctus, belliger juuenis, in certamine singularis, in triumpho gloriosus, uincendo ueteranus, patiens in aduersis, prudens in pericalis, in peccato proprio dolens, in alieno funere lugens, pronus ad poenitentiam, uelox ad ueniam. In conuicio mitis, ad misericordiam facilis. Qui inimicum regem, dum posset, innocuum non tantum reservauit traditum, sed et vindicavitoccisum. Hic leonem et ursum sine gladio interfecit, citharae suauitate inmundum spiritum pepulit, gigantem expugnauit”.

${ }^{818}$ Reydellet ha observado que Isidoro admiraba a Leovigildo por haber unificado los territorios hispanos, hecho muy significativo para él; De laude Spaniae sería una prueba de ello. Un análisis sobre la Alabanza en: FONTAINE, J.: Isidoro de Sevilla: Génesis y originalidad de la cultura hispánica en tiempo de los visigodos... p.171 y ss. Considerando este aspecto se puede llegar a entender los motivos que llevaron a Isidoro a omitir la condición católica de Hermenegildo en sus relatos. REYDELLET, M.: La royauté dans la littérature latine de Sidoine Apollinaire à Isidore de Séville...p. 534. Salvador Rus ha observado que la política isidoriana tuvo como objetivo la consolidación del territorio y la estabilidad del reino. SALVADOR RUS, R.: "Unidad y paz en el reino visigodo. Dos aspectos del pensamiento político de Isidoro de Sevilla”, p. 81-94.

${ }^{819}$ ISID. Hist. Goth., p 268. “... uir quidem strenuus in armorum arte, sed tamen expers uictoriae”; "Hic in uita plurima inlicita fecit (...)”. 
estrecha amistad ${ }^{820}$ — fue retratado como un rey sabio y clemente, que conoció el sabor de las victorias militares obtenidas por sus conocimientos bélicos y a través de sus generales que dirigieron por él campañas, una forma indirecta, pero no por ello menos gloriosa ${ }^{821}$. Relató con detalles las victorias de Suintila, quien, además, poseía las virtudes mayestáticas definidas por Isidoro:

“(...) fides, prudentia, industria, in iudiciis examinatio strenua, in regendo cura praecipua, circa omnes munificentia, largus erga indigentes et inopes misericorida satis promptus, ita ut non solum prínceps populorum, sed etiam pater pauperum uocari sit dignus "822

Jamie Wood plantea, como resultado de extenso estudio sobre los escritos del hispalense, que Isidoro remarcó los triunfos bélicos de los reyes godos para señalar su superioridad militar. Según este autor, los conceptos de piedad, justicia y la victoria militar fueron elementos fundantes de la ideología de gobierno de los reyes.

La intervención política de Isidoro tuvo su punto culmine en el IV Concilio de Toledo del año $633^{823}$, bajo el auspicio de Sisenando. En esa reunión, se dispuso un canon por el cual se instaba a guardar el juramento de fidelidad realizado a los reyes, lo cual es un síntoma incontrastable de la debilidad estructural de la realeza ${ }^{824}$. Asimismo, se intimó, bajo la amenaza de sufrir la sentencia de anatema, a Sisenando y a los futuros reyes para que fueran moderados con el pueblo y que se comportasen de manera justa y piadosa ${ }^{825}$, evitando actuar

\footnotetext{
${ }^{820}$ FONTAINE, J.: Isidoro de Sevilla: Génesis y originalidad de la cultura hispánica en tiempo de los visigodos... p. 102. Reydellet, M.: La royauté dans la littérature latine de Sidoine Apollinaire à Isidore de Séville...p. 543.

${ }^{821}$ ISID. Hist. Goth., p. 272: "eloquio nitidus, sententia doctus, scientia litterarum ex parte inbutus", p. 272 y 274: "Adeo post uictoriam clemens (...)"; "In bellicis quoque documentis ac uictoriis clarus". "(...) Astures enim rebellantes misso exericitu per ducem suum Richilanem in dicionem suam reduxit. Roccones arduis montibus undique circumsaeptos similiter per duces deuicit. De Romanis quoque praesens feliciter triumphauit et quasdam urbes pugnando subegit."

${ }^{822}$ ISID. Hist. Goth., p 278.

${ }^{823}$ El IV Concilio de Toledo fue el ámbito donde Isidoro ejerció toda su influencia política; se considera que los cánones promulgados tienen impronta isidoriana. Ver en especial: CROUCH, J.: "Isidore of Sevilla and the Evolution of Kingship in Visigothic Spain", Mediterranean Studies, 4, 1994, pp. 9 -26. También WooD, J.: The Politics of Identity in Visigothic Spain: religion and power in the histories of Isidor of Seville... p. 145.

${ }^{824}$ Ver capítulo 4.

${ }^{825}$ Los conceptos de iustitia y pietas fueron fundamentales de la visión del buen rey que Isidoro construyó. Sobre la importancia de estos ver: WoOD, J.: The Politics of Identity in Visigothic Spain: religion and power in
} 
de forma soberbia o cayendo en los deseos más crueles. A continuación, los reunidos condenaron a Suintila por sus crímenes - los cuales no son detallados - y lo despojaron de sus bienes, salvo de aquellos que Sisenando le dejara por su piedad, ya que enriqueció con premios a los buenos y a los malos no los relegó ${ }^{826}$.

Las expectativas de Isidoro se cumplieron escasamente. La compleja realidad política del reino hizo que el sistema sucesorio y las conductas modélicas propuestas fracasasen. De hecho, las situaciones políticas, a medida que se sucedían, desencadenaban contradicciones en los argumentos esgrimidos por los miembros de la Iglesia ${ }^{827}$. Isidoro tuvo momentos de participación política que constituyeron un opuesto a sus acciones previas: estas tensiones llegaron, incluso, a contradecir la fórmula difundida por él sobre las cualidades de un rey ${ }^{828}$.

Los escritos de Julián de Toledo también son objeto de consideración para tratar el problema de la legitimidad regia desde el discurso eclesiástico. Se insiste en la innovación que realizó Julián al nombrar a Wamba con el epíteto religiosus, como parte de la intitulación regia en la Historia Wambae. Teillet afirma que la fórmula princeps religiosus daba cuenta del carácter sacro de Wamba ${ }^{829}$. García Herrero (al igual que Teillet antes) realiza un exhaustivo trabajo sobre las obras de Julián, llegando a interesantes conclusiones. En primer lugar, el rey fue calificado de religiosus, término que englobaba diferentes condiciones. Debía ser humilde, misericordioso, clemente, devoto de Dios, sabio, entre otras cualidades. Sin embargo, este autor especifica que Julián completó el modelo de conducta de los reyes con otras condiciones: las virtudes del rey guerrero ${ }^{830}$.

García Herrero argumenta que

the histories of Isidor of Seville... p. 141.También: VALVERDE CASTRO, Ma . R.: Ideología, simbolismo y ejercicio del poder real en la monarquía visigoda... p. 213.

${ }^{826}$ Concilios, Toledo IV, año 633, c. LXXV, p. 221: “(...) praeter in id quod consequuti fuerint pietate clementissimi principis nostri, cuius gratia et bonos donorum praemiis ditat et malos a beneficentia sua congrue non separat".

${ }^{827}$ Crouch, J.: "Isidore of Sevilla and the Evolution of Kingship in Visigothic Spain", p. 17. WoOD, J.: The Politics of Identity in Visigothic Spain: religion and power in the histories of Isidor of Seville... p. 189.

${ }^{828}$ VelázQuez Soriano, I. y RIPOLl, G.: "Isidoro y su época. A modo de introducción", Antiquité Tardive, 23, 2015, pp. 43-45.

${ }^{829}$ TeILlet, S.: "L'Historia Wambae est-elle une oeuvre de circunstance?, "Antigüedad y Cristianismo, III, 415-424.

${ }^{830}$ GARCÍA Herrero, G.: "Julián de Toledo y la realeza visigoda", Antigüedad y Cristianismo, VIII, 1991, 201256. Ver también: VelÁzQUEZ SORIANO, I.: "Wamba y Paulo: Dos personalidades enfrentadas y una rebelión”, Espacio, Tiempo y Forma, Serie II, $H^{\circ}$. Antigua, t. II, 1989, pp. 213-222. 
“(...) en las páginas de Julián, el tema (la condición de brillante jefe militar) encuentra una justificación y fundamentación ideológica acordes con la reformulación del ideal monárquico en términos propios del cristianismo que, en las obras de autores anteriores se había dirigido a la identificación del monarca mediante otras virtudes, especialmente evangélicas o, en todo caso, neotestamentarias" $" 831$

Sobre la innovación de Julián con respecto a la virtud militar, debemos matizarla. Sin ir más lejos, ya apuntamos que Isidoro destacó en todos los casos el aspecto militar de los reyes. Esta tradición también se halla presente en la Crónica de Juan de Bíclaro, en cuyas entradas figuran las victorias bélicas conseguidas por los reyes. Sobre esto Castro apunta que “(...) la dimensión bélica, de capital importancia para una aristocracia que valoraba sumamente el desempeño en la guerra, no debía ser excluida de la legitimación monárquica" ${ }^{932}$. La autora reconoce que, a pesar de su importancia, este aspecto no fue suficiente, puesto que la dimensión moral, ligada a la pastoral, cobraba mayor relevancia, según su opinión.

Durante el siglo VII, la inteligencia católica organizó un discurso legitimador del poder regio en torno a tres núcleos de sentidos: el carácter sagrado del rey, la función pastoral/religiosa y el carácter militar. Estos núcleos se enlazaron entre sí para dar significado al cargo del rey desde el punto de vista de la Iglesia.

Ahora bien, el relevamiento de los documentos y de la bibliografía secundaria nos permite dudar sobre la dimensión performativa del discurso eclesiástico. Varios son los problemas que obstaculizaron su efectividad. En primer lugar, no hubo un claro consenso sobre el alcance del fuero sagrado de los reyes. Durante la última parte del siglo VI y todo el VII, hubo una fuerte disparidad de criterios. Isidoro impulsó un modelo de conducta para los reyes con la clara intención de orientar y, sobre todo, supervisar a la institución regia. Creía que la obediencia y la fidelidad se deberían conservar de acuerdo con las virtudes desplegadas

\footnotetext{
${ }^{831}$ GARCía Herrero, G.: "Julián de Toledo y la realeza visigoda”, p. 243.

${ }^{832}$ CASTRO, D.: Palabras inmortales: poder, autoridad y exégesis bíblica en el reino visigodo de Toledo (589711) ..., p. 236.
} 
por los máximos gobernantes ${ }^{833}$. Consideró lícito despojar al rey de su título si no obraba según los designios del clero. Dell'Elicine remarca que los obispos reunidos en Toledo en el año 646 dieron sobradas muestras de que obedecerían al rey si este probaba ser digno de su cargo $^{834}$. A medida que los avatares políticos transcurrían, los miembros de la Iglesia cambiaban de opinión sobre la sacralidad regia, sumándose al juego secular. Este factor favoreció a las fisuras e inconstancias del discurso eclesiástico. A su vez, la elasticidad que demostraron los actores políticos ante los discursos eclesiásticos debe alertarnos sobre su efectividad. La opinión dada por Velázquez, Barroso y Morin de Pablos se vuelve aquí relevante.

Además de los vaivenes discursivos, el proyecto ideológico de la Iglesia sobre la figura del rey estaba en plena configuración. La liturgia cristiana, la teoría del origen divino del poder regio - y su consiguiente misión salvadora del reino — y el modelo bíblico de rey deseable se construyeron en secuencias, se desplegaban a medida que la vida política secular del reino transcurría. Esto significa que los sucesivos reyes comenzaron sus gobiernos sin contar con un sistema ideológico acabado o consolidado. Incluso algunos buscaron nuevas formas de legitimarse desde el plano discursivo y ritual, como fue el uso de los epítetos regios o la conversión al catolicismo. Un análisis de la implementación de la sagrada unción (el acto religioso más importante de todo el concierto católico) servirá como ejemplo.

En el rito de la unción, los obispos esparcían óleos sagrados sobre la cabeza del futuro rex gothorum, la gracia divina conferida transmutaba al simple mortal en una persona elegida por Dios, superior al resto, digna de veneración y respeto, equiparable a los buenos reyes de la Biblia.

\footnotetext{
${ }^{833}$ Barroso Cabrera, R., Morín de Pablos, J. y Velázquez Soriano, I.: "La imagen de la realeza en el reino visigodo de Toledo a través de la iconografía y la epigrafía”, p. 503.

834 DelL' Elicine, E.: 'Pensando al rey: los puntos de vista de la iglesia visigoda acerca de la institución monárquica (589- 711), Cuadernos medievales, Mar del Plata- Bahía Blanca, 2009, pp. 37- 38.
} 
La historiografía especializada debate cuándo se realizó la primera unción regia ${ }^{835}$. Algunos autores declaran a Wamba como el primer ungido de Dios ${ }^{836}$, otros creen que fue Sisenando ${ }^{837}$, Hermenegildo ${ }^{838}$, Recaredo $\mathrm{I}^{839}$ o, incluso, el traidor Paulo ${ }^{840}$.

Como lo destaca Collins, la unción fue parte del proceso de entronización del nuevo rey $^{841}$, trascendental por su origen veterotestamentario. Y sin embargo, sus huellas en la documentación son débiles, tanto que imposibilitan a los historiadores fijar una fecha de implementación del rito. En esta ocasión el silencio se torna elocuente. Revela que la sacralización de los reyes a través de la unción no se aplicó de manera sistemática hasta el reinado de Wamba, es decir, hasta el año 672.

Por lo tanto, en los años pasados y siguientes de Wamba, el discurso proveniente de las filas católicas se fue forjando, completando, discutiendo. Estaba en plena formulación.

También resaltamos que Wamba, rey designado bajo todas las reglas establecidas en los cánones eclesiásticos y ungido, fue destronado en un ardid que contó con el auspicio de la Iglesia. Esto es un indicio claro de que la ideología católica que elevaba al rey a un lugar reservado con funciones pastoriles, intocable por ser el elegido de Dios, no fue percibida ni reconocida por una parte de la aristocracia. La violencia ejercida en los anteriores

\footnotetext{
${ }^{835}$ Los autores también discuten si el rito de la unción significó la subordinación del rey al poder sacerdotal o, al contrario, el rey se elevaba sobre la Iglesia. El primer punto de vista es defendido por DíAZ MARTínEZ, P.C.: "Rey y poder en la monarquía visigoda", p. 190; BARBERO, A.: "El pensamiento político visigodo y las primeras unciones regias en la Europa medieval", Hispania, 115, 1970, p. 56. Es segundo lo sostienen VALVERDE CASTRO, Ma. R.: Ideología, simbolismo y ejercicio del poder real en la monarquía visigoda: un proceso de cambio, p. 205; KING, P.D.: Derecho y sociedad en el reino visigodo, pp. 68 y 69.

${ }^{836}$ REYDELLET, M.: La royauté dans la littérature latine de Sidoine Apollinaire à Isidore de Séville, p. 567. TEILLET, S.: Des Goths à la nation gothique: les origines de l'idée de nation en Occident du Ve au VIIe siècle, París: Belles Lettres, 1984.

${ }^{837}$ VALVERDE CASTRO, Ma. R..: Ideología, simbolismo y ejercicio del poder real en la monarquía visigoda: un proceso de cambio, p. 207; DIA, P.C.: "Rey y poder en la monarquía visigoda", p. 189. KING, P.D.: Derecho y sociedad en el reino visigodo p. 68. HILLAGARTH, J.N: "Historiography un Visigothic Spain", p. 184. BARBERO, A.: "El pensamiento político visigodo y las primeras unciones regias en la Europa medieval", p. 68.

${ }^{838}$ BARROSO CABRERA, R. Y MORÍN DE PABLOS, J: "Imagen soberana y unción regia en el reino visigodo de Toledo", Codex Aquilarensis, 20, 2004.

${ }^{839}$ SANCHEZ AlBORNOZ, C.: "La Ordinatio principis en la España goda y postvisigoda", Cuadernos de Historia de España, 35, 1962, pp. 14-16; BRONISCH, A. P.: Reconquista y guerra santa. La concepción de la guerra en la España cristiana desde los visigodos hasta comienzos del siglo XII, Granada: Universidad de Oviedo, 2006, pp. 446 y ss.

${ }^{840}$ MARTIN, C.: "L'innovation politique dans le royaume de Tolède: le sacre du souverain", en PÉNEAU, C. (ed.), Elections et pouvoirs politiques du VIIe au XVIIe siécle, 2008, pp. 281-300.

${ }^{841}$ COLLINS, R.: "Julian of Toledo and the Royal Succession in Late Seventh-Century Spain", en WoOD, I. Y SAWYER, P. (eds.): Early Medieval Kingship, Leeds: University of Leeds, 1977, pp. 45-48.
} 
destronamientos, y los que siguen, también prueban que este núcleo del discurso de la Iglesia, a pesar de ser parte del campo de la producción simbólica del reino, estuvo lejos de constituirse como el dominante.

Reyes guerreros

El sistema de representación ideológica que legitimaba al rey poseía varios niveles. Como lo ha planteado McKitterick, uno de ellos fue el que condensaba la imagen de reyguerrero. La aristocracia valoraba el compendio de habilidades guerreras, como el coraje, la valentía y el valor en el campo de batalla, el talento como estratega y jefe militar. Agreguemos la generosidad en el reparto del botín de guerra y de los bienes, que el rey administraba y distribuía entre sus seguidores. En este apartado, constataremos que este núcleo discursivo fue el que mejor reflejaba las expectativas colectivas de la aristocracia con respecto a su rey. Este programa ideológico tuvo sus propios ritos y formas de propaganda, que fusionaba elementos provenientes de la cultura laica con los de la religión cristiana. De hecho, la Iglesia fue la principal promotora de la imagen del rey-caudillo, tradición que se remonta a siglos anteriores, y en palabras de Orlandis:

"La imagen del rey-caudillo, que marcha a la guerra a la cabeza de sus hombres, se mantuvo en la Monarquía católica, hasta el punto de dejar su impronta en la liturgia hispana" ${ }^{\text {842. }}$

A su vez, señalamos que los discursos en torno al rey-guerrero, de tono argumentativo, cumplieron con los requisitos de ser inteligibles y veraces. Para tratar este problema exploraremos la identidad aristocrática laica militar visigoda, y qué elementos provenientes de esta fueron esenciales para configurar el sistema de creencias que lograban que un acto del rey fuera ilocucionario.

Como constata Wickham, la aristocracia del mundo temprano medieval occidental adoptó una identidad militar, y hubo una expansión de los valores masculinos clásicos (honor,

${ }^{842}$ ORLANDIS, J.: Historia del reino visigodo español..., p. 167. 
valentía y lealtad) ${ }^{843}$. Depreux señala que la portación de armas, y lo que comprende (por ejemplo, la caza), fue una distinción fundamental entre laicos y los miembros del clero. De hecho, la entrega de armas a un hombre libre marcaba el fin de la infancia, constituía un rito de paso $^{844}$. Asimismo, Le Jan marca que la posesión de caballos fue un elemento distintivo de la elite guerrera y un elemento asociado al ejercicio del poder ${ }^{845}$. Para el mundo franco, la autora corrobora que la educación militar que recibían los jóvenes era complementada con la enseñanza de la prudencia ${ }^{846}$.

Diversos documentos provenientes del reino visigodo también contienen el universo de estos valores culturales. Si bien la mayoría fueron producidos en círculos eclesiásticos, no por ello carecían de sentido para la audiencia laica. Un claro ejemplo lo constituye un breve tratado de origen visigodo ${ }^{847}$ titulado Institutionum disciplinae ${ }^{848}$-cuya autoría es

${ }^{843}$ Wickham, C.: El legado de Roma: una historia de Europa de 400 a 1000, Pasado y Presente, 2013, cap. 8. Para un panorama general sobre los valores guerreros en la Temprana Edad Media ver: MCKITTERICK, R.: $L a$ alta Edad Media. Europa 400-1000 ..., especialmente pp. 36-53; LE JAN, R.: "Frankish giving or arms and ritual of power: continuity of arms and rituals of power in the carolingian period", en THEUWS F. and NELSON J.L., (eds.), Rituals of power, from Late Antiquity to the Early Middles Ages, Leiden; Boston; Köln: Brill, 2000. (The transformation of the Roman world; Vol. 8). MorsSEL, J.: La aristocracia medieval. El dominio social en occidente... cap. 1.

${ }^{844}$ DePreuX, P.: Les Sociétés occidentales du milieu du vie à la fin du ixe siècle, Rennes: Presses universitaires de Rennes, 2015, pp. 149-184. Le Jan remarcó este aspecto en. LE JAN, R.: Famille et pouvoir dans le monde franc (VIIe-Xe siècle). Essai d'anthropologie sociale, Paris: Publications de la Sorbonne, 1995, pp. 64-66; "Frankish giving or arms and ritual of power: continuity of arms and rituals of power in the carolingian period", p. 283.

${ }^{845}$ LE JAN, R.: "Frankish giving or arms and ritual of power: continuity of arms and rituals of power in the carolingian period", pp. 282-283.

${ }^{846}$ LE JAN, R.: "Frankish giving or arms and ritual of power: continuity of arms and rituals of power in the Carolingian period", pp. 282-283 "It was not just that this military education had value in itself. It was bound up in the wielding of power. It therefore had to be complemented by moral training: the young noble had to acquire prudentia, the practical wisdom that leaders needed".

${ }^{847}$ Los argumentos esgrimidos por Sánchez Prieto, sumados a nuestra investigación, indican el origen visigodo de esta obra. SÁNCHEZ PRIETO, A.B: "Las Institutionum Disciplinae: programa educativo para un noble godo", en Vergara Ciordia, J., SÁNCHEZ BAREA, F., Y COMElla GutiÉRreZ, B. (coords.): Ideales de formación en la Historia de la Educación, Madrid: Editorial Dykinson, 2011, pp. 87-104.

${ }^{848}$ Durante un tiempo se consideró a Isidoro de Sevilla como su autor. La opinión más extendida entre los especialistas es que la Institutionum disciplinae fue escrita en un ambiente visigodo, fechado después de la muerte de Isidoro y el siglo VIII. RichÉ, P.: "L'éducation a l'époque wisigothique: les Institutionum disciplinae", Anales Toledanos 3, 1971, p. 180. Para profundizar sobre el debate de esta obra ver: FONTAINE, J.: "Quelques observations sur les Institutiones disciplinae", Ciudad de Dios, 181, 1968, pp. 617-655. GÁZQUEZ, J.M.: "Sobre el origen hispano-visigodo de las Institutionum disciplinae", Faventia, 1979, pp. 3546. RICHÉ, P.: "L'éducation a l'époque wisigothique: les Institutionum disciplinae". SÁNCHEZ PRIETO, A.B: "Las Institutionum Disciplinae: programa educativo para un noble godo". 
desconocida, pero atribuida a un miembro de la Iglesia_-, el cual detalla aquellas artes que un miembro de la aristocracia debía dominar. La práctica eclesiástica de escribir para la aristocracia laica no fue extraña: Valerio del Bierzo da noticias de un libro (el cual no se ha conservado) que escribió para el hijo de una buena familia ${ }^{849}$.

Las Institutionum disciplinae proponen un programa ideal de educación para un aristócrata laico. A corta edad comienza el estudio de las letras. Seguido de ello, debe cantar “carmina maiorum" 850 y practicar hasta que las palabras, sus conversaciones y opiniones salgan de su boca de forma clara y equilibrada, es decir, dominar el arte de la elocuencia. Al mismo tiempo, entrena su cuerpo para lograr un andar soberbio, opuesto a lo desordenado. Al alcanzar la juventud, debe ejercitarse por las montañas o el mar, practicar el lanzamiento de la jabalina y la equitación. También correr, saltar, luchar, competir con sus compañeros en la palestra, recorrer los bosques. Se lo insta a perseguir y azuzar a las fieras, y ponerse a prueba siendo el primero o de los primeros en herirlas, así como probar su velocidad en una carrera contra ellas. Incluso la navegación es una destreza por aprender, sobre todo dominar la fuerza del agua ${ }^{851}$.

En su etapa madura, la prudencia y justicia, la fortaleza y templanza deben cultivarse. Las asignaturas que componían el trivium y el quadrivium, pero con algunas diferencias y agregados, deben ser estudiadas. Sánchez Prieto destaca que en las Institutionum disciplinae se ha invertido el orden de la retórica y de la dialéctica, y se ha introducido derecho, filosofía y medicina. Se omite (tal vez por un error en la transmisión del texto) la aritmética, y se suplanta la astrología por la astronomía. La autora observa, trayendo a colación distintos autores, entre ellos a Isidoro, que esta forma de presentar las asignaturas clásicas no fue tan poco común ${ }^{852}$.

Igualmente, se encomienda a que sea un modelo de virtudes, el cual debe huir

${ }^{849}$ VAL. Replic. "Quum in eodem necessitudinis loco quendam bonorum filium enutrirem, et illi pro erudition precipuum conscripsissem labellum (...).”, p. 284.

${ }^{850}$ Seguimos la transcripción de GÁZQUEZ, J.M.: "Sobre el origen hispano-visigodo de las Institutionum disciplinae", p. 37.

${ }^{851}$ Estos ejercicios aparecen en el Panegírico de Trajano de Plinio el Joven; sin embargo, sostiene Sánchez Prieto, el destinatario de las Institutionum Disciplinae se identificó con estas actividades largamente documentadas para las sociedades de la temprana Edad Media. SÁNCHEZ Prieto, A.B: "Las Institutionum Disciplinae: programa educativo para un noble godo", pp. 94 y ss.

${ }^{852}$ Ibidem, pp. 98-100. 
"de los atractivos de las diversiones vergonzosas y de las vanidades de los espectáculos del circo, y de todas las ignominias de las pasiones; manténgase como hombre casto, varón sobrio, hombre de prudentes determinaciones, de buen sentido, humilde, paciente, continente, piadoso, defensor de la patria, temeroso de las leyes y juicios (...)"853

Por último, se aconseja no ser avaro ni apropiarse de dominios a expensas de otros y conservar los pactos de amistad (amicitiarum foedus). Sánchez Prieto remarca, acertadamente, que el catecismo está ausente de este programa educativo ${ }^{854}$.

En síntesis, este tratado realza la elocuencia, el entrenamiento militar, la destreza física y el cultivo de las relaciones sociales como atributos propios de un aristócrata, elementos que hallamos en otros documentos contemporáneos.

Los especialistas en la historia de la cultura en el reino visigodo señalan la trascendencia del lenguaje, su difusión y enseñanza, en la instrucción de la elite ${ }^{855}$. La aristocracia valoraba de forma positiva el manejo de la oratoria ${ }^{856}$; de ahí el impulso a las

853 Seguimos la traducción de GÁzQUEZ, J.M.: "Sobre el origen hispano-visigodo de las Institutionum disciplinae", p. 40.

${ }^{854}$ SÁNCHEZ PRIETO, A.B: “Las Institutionum Disciplinae: programa educativo para un noble godo”, pp. 100 y 101.

${ }^{855}$ Sobre los diversos documentos y los fondos documentales manejados por los intelectuales visigodos particular ver: MARTíN IGLESIAS, J.C: "La biblioteca cristiana de los padres, hispanovisigodos (siglos VI-VII)", Veleia, 30, 2013, pp. 260-288. La información más sólida es sobre el clero, pues la mayoría de la información proviene de este círculo social. Para un panorama general ver: RicHé, P.: Éducation et Culture dans l'Occident Barbare VIe-VIIe siecles, Paris: Éditions du Seuil, 1962. MARTínEZ, B. B: La educación en la Hispania antigua y medieval, Madrid: Ediciones Morata, 1992, p. 128 y ss. Bibliografía específica y críticas a estas monografías: DiAGO JiMÉNEZ, J.M.: "Las instituciones educativas de carácter religioso en el reino hispanovisigodo de los siglos VI y VII a través de los cánones conciliares y las reglas monásticas”, Espacio Tiempo y Forma. Serie III, Historia Medieval, 31, 2018. Sobre la educación del clero ver en especial: UdAONDO PUERTO, F.J.: "El sistema escolar en la Hispania visigoda. El ejemplo de Valerio del Bierzo", Helmantica: Revista de filología clásica y hebrea, 54, 2003, pp. 391-445. Sobre el sector laico también se poseen datos. VELÁZQUEZ SORIANO sostiene que un porcentaje nada despreciable (aunque no calculable) de la población laica -el sector acomodado o aquellos que cumplían funciones de tipo notariales o contables- poseía un nivel de instrucción que le permitía elaborar y entender documentos de varios tipos, como jurídicos o contables. Siguiendo a García Gallo y a Díaz Díaz, también reconoce una extendida alfabetización primaria en las zonas rurales, lejos de los epicentros intelectuales. VELÁZQUEZ SORIANO, I.: Las pizarras visigodas. (Entre el latín y su disgregación. La lengua hablada en Hispania, siglos VI-VIII), Real Academia Española, 2004, pp. 50-51. Si bien existió un especial desarrollo del arte de la escritura en un sentido clásico, mas, sostiene Diago Jiménez, de forma deficitaria.

${ }^{856}$ Con respecto a la transcendencia de la oralidad en las sociedades que, si bien conocen la escritura, conservan una importante tradición oral ver la exposición de Ong. El autor rescata el concepto verbomotor acuñado por 
prácticas del lenguaje. La elocuencia fue un talento deseado como atributo de los líderes guerreros, fenómeno de larga tradición y extensión geográfica.

Tácito relata que en las asambleas de los germanos el rex vel princeps eran escuchados más por la persuasión que por el poder de mando. Si las palabras eran bien recibidas, se agitaban las armas; si lo contrario sucedía, el rechazo se proclamaba a gritos ${ }^{857}$. Gautier observa que en el norte europeo el uso de la palabra ocupó un lugar privilegiado en el momento de definir las jerarquías internas de las bandas armadas. En su estudio, demuestra que en las diferentes actividades competitivas no bélicas (juegos, desafíos y combates) un hombre que callaba era tan denostado como un cobarde en la batalla ${ }^{858}$. En la Italia lombarda encontramos otro ejemplo del uso de la importancia de los discursos ${ }^{859}$. Luego de una batalla, Alboíno, príncipe de los longobardos, junto a un grupo de guerreros se presentó en la casa del vencido gépido, Turisindo, con el fin de conseguir las armas de su hijo caído en combate. Como marcaba la costumbre, el anfitrión invitó a su mesa a los recién llegados. Sin embargo, los gépidos no toleraron ver sentado al asesino de su príncipe. El mismo rey con unas breves palabras hizo manifiesto su malestar; esto llevó a que uno de sus hijos comenzase a insultar

Jousse en 1925, para dar cuenta de las interacciones orales como principales mediadoras de las relaciones sociales. ONG, W.: Oralidad y escritura. Tecnologías de la palabra, México: FCE, 2006, en especial p. 72 y ss. Valoramos el trabajo de Ong en la medida que nos permite comprender el papel central de las palabras dichas en la sociedad visigoda. Asimismo, la gestualidad en las expresiones de tipo orales es sumamente importante y, aunque no sea fácil de reconocer en el papel, tuvo también su rol en las piezas oratorias de los reyes y aristócratas. La palabra magistralmente pronunciada y la gestualidad permitían subyugar los ánimos de los destinatarios oyentes. Sobre los gestos remito al estudio clásico de POYATOS, F.: La comunicación no verbal, Madrid: Istmo, 1994.

${ }^{857}$ Pasaje completo: "Mox rex vel princeps, prout aetas cuique, prout nobilitas, prout decus bellorum, prout facundia est audiuntur, auctoritate suadendi magis quam iubendi potestate. Si displicuit sententia, fremitu aspernantur; sin placuit, frameas concutiunt: honoratissimum adsensus genus est armis laudare", TACITUS, Germ. 11.5-6, p. 37. Mucho se ha escrito sobre el uso de este documento, pues algunos lo consideran un "espejo" de la sociedad romana. Sin embargo, apunta Rives, su implementación en el estudio de la sociedad germana puede ser útil siempre que se lo contraponga con otra información. RIVES, J.B: "Germania”, en PAGÁN, V. E. (ed.): A companion to Tacitus, Reino Unido: Wiley-Blackwell, 2012.

${ }^{858}$ GAUTIER, A.: "Les activités compétitives au sein des bandes armées de l'Europe du Nord au Haut Moyen Age”, en Bougard, F., Le Jan, R y Lienhard, T. (eds.):Agôn. La compétition, Ve-XIIe siècle., Turnhout: Brill, 2012, (Haut Moyen Âge, 17), p. 75-92.

${ }^{859}$ PAULI DiACONI, HL, Libro I, cap. 24, pp. 61 y 62. "Perge, ait, in campum Asfeld, ibique procul dubio poteris experiri, quam valide istae quas equas nominas praevalent calcitrare; ubi sic tui dispersa sunt ossa germani quemadmodum vilis iumenti in mediis pratis". "Non ese victoriam Deo placitam, cum quis in domo propria hospitem perimit".

Las traducciones pertenecen a PABLO DIÁCONO, Historia de los Longobardos, introducción, traducción y notas de Pedro Herrera Roldán, Universidad de Cádiz, 2006, p.78 y 79. 
a los invitados comparando sus polainas con las zancas blancas de las yeguas. Ante los agravios, un compañero de Alboíno contestó:

"Ve al campo de Asfeld y allí podrás comprobar sin lugar a duda qué recias coces pueden dar esas que llamas yeguas; los huesos de tu hermano están allí esparcidos igual que los de un vil jumento en medio de un prado".

Ante estas palabras, los ánimos se enardecieron de tal forma que las armas fueron desenfundadas. Sin embargo, Turisindo evitó la pelea aduciendo que "no agradaba a Dios la victoria cuando alguien mataba en su propia casa a un huésped". Finalmente, se entregaron las armas a Alboíno, quien regresó a su reino y fue elogiado por su audacia. Del mismo modo, se exaltó la fidelidad y actitud de Turisindo.

La hazaña de los longobardos radicó en no callarse y defenderse ante los insultos recibidos a pesar de estar en desventaja numérica. A su vez, este pasaje de la Historia Langobardorum expone el poder de la palabra en varios sentidos: el primero, como catalizador de la violencia física; segundo, como la palabra pronunciada constituía una promesa a cumplir. Además, queda en evidencia que el ingenio a la hora de contestar injurias fue una virtud valorada.

En la España visigoda la elocuencia fue un talento que los contemporáneos consideraron digno de recordar en las biografías o hagiografías de los hombres de vida pública que disfrutaron y practicaron aquella gracia ${ }^{860}$. Un pasaje de las VSPE relata la disputa entablada entre los obispos Masona, católico, y Sunna, del culto arriano, por el disfrute de la basílica de Santa Eulalia de Mérida. Por orden del rey Leovigildo, ambos se enfrentaron en una discusión ante jueces, en la cual Masona aplastó a su contrincante dando un discurso erudito y brillante en elocuencia, según destaca el autor, y cuya gestualidad invitaba a la calma ("sanctus Masona episcopus, ut erat summe grauitatis summeque prudentie, diu multumque oculis celo intentis silentium tenuit”); al contrario, Sunna prefirió dar su discurso enojado y utilizando un lenguaje inapropiado ("Sunna episcopus prius loqui exorsus est cepitque nefanda oris strepentia, aspera, scabra et obscenosa summo cum fragre

\footnotetext{
${ }^{860}$ Además de los ejemplos desarrollados, podemos considerar a Valerio del Bierzo como un gran orador. Sus relatos autobiográficos dan grandes muestras de su poder de convicción.
} 
producere uerba" $)^{861}$. En ambos casos la gestualidad acompañó a la cadencia y la elección de las palabras. Con menos detalles, tanto Isidoro de Sevilla como Idelfonso subrayan la elocuencia como una característica digna de ser mencionada en las biografías de los personajes ilustrados de sus épocas ${ }^{862}$. Del mismo modo, Isidoro realzó la elocuencia de Sisebuto como un atributo admirable de su personalidad ("Fuit autem eloquio nitidus") y designó a todos los godos como "ingenio alacres" 863 .

Estos documentos señalan que la oratoria fue una pieza central y muy valorada en el ejercicio del poder, ya que esclarecía posiciones en los ámbitos en los cuales las armas estaban vedadas. Por lo tanto, los jóvenes aristócratas debían prepararse lo mejor posible en el arte de la persuasión, pues ya fuesen laicos o eclesiásticos muchas de las disputas políticas se definieron a través de discusiones públicas (el desarrollo de las distintas posturas en los Concilios son muestras claras de esto).

Asimismo, la oratoria fue esencial en el campo de batalla. El arte de la persuasión era una habilidad esencial de los jefes guerreros, un atributo que les permitía seducir a su público con argumentos que no siempre entraban dentro del campo del rigor y la precisión. Si bien los discursos que han sobrevivido lo han hecho a través de la pluma de un eclesiástico, consideramos que al estar escritos para un auditorio amplio los elementos de análisis encontrados son válidos. Contamos con una pieza muy significativa: la arenga de Wamba a sus tropas.

Julián de Toledo introdujo una pieza de oratoria pronunciada por Wamba ante sus tropas, las cuales estaban inquietas por la noticia de la sedición de Paulo apoyada por los francos. Wamba les recordó a sus soldados lo vergonzoso que sería no ir a enfrentarse con los galos, pues los tratarían de afeminados y delicados (effeminatos et molles) $)^{864}$ ya que era sabido que su formación guerrera era superior y, además, debían con las armas vencer a quienes pretendían respaldar a la sedición. Al cerrar su discurso, los ánimos de los soldados se encendieron. El contrincante, Paulo, también pronunció un discurso a sus hombres. Según

\footnotetext{
${ }^{861}$ VSPE, p. 61.

${ }^{862}$ ILD. TOL. De vir. Illustr., pp. 118, 126, 131, 134. IsID. De vir. Illustr. pp. 133, 135, 137, 143, 149. Muchas veces asocia a la elocuencia con ingenio. Por ejemplo, de Leandro se recuerda como "uir suauis eloquio, ingenio praestantissimus". ISID. De vir. Illustr., p. 149.

${ }^{863}$ ISID. Hist. Goth., p. 272 y 284.

${ }^{864}$ IUL. TOL. $H W$, p. 224.
} 
Julián, para llenar sus espíritus de valentía les dijo que todo el vigor de lucha de sus enemigos se había desvanecido ${ }^{865}$. El discurso de Wamba es probable que haya sido casi tal cual lo relató Julián, pues en su ley militar $(9,2,8)$ indicó que la carencia de valentía era una falta sumamente grave ${ }^{866}$. Este cruce de fuentes amplía el potencial de las piezas escritas por los eclesiásticos.

En relación con los valores relacionados con la preparación física y la cultura militar que menciona las Institutionum disciplinae, la documentación visigoda proporciona piezas sumamente interesantes que permiten comprender que la cultura laica tuvo un carácter hegemónico. En otras palabras, el total de la aristocracia, laica y eclesiástica, compartió este universo compuesto por principios ideológicos militares; es decir, destacaban la valentía, el coraje, la fuerza, el liderazgo y la generosidad.

Ya hemos señalado como Isidoro ensalzó una y más veces las cualidades guerreras de los reyes en varios de sus escritos. En el cierre de su Historia Gothorum vuelve sobre este tópico, extendiendo las alabanzas a todo el pueblo visigodo. Allí, glorifica, por un lado, sus características físicas y aptitudes bélicas (eran veloces, fuertes físicamente, orgullosos de su estatura, diestros en el uso de las armas y de los caballos en la guerra, participan en competiciones, navegan los mares) y, por el otro, las actitudes heroicas y valientes (entrenados para la batalla, preparados para sufrir heridas) ${ }^{867}$. Notamos, que la Recapitulatio de Isidoro posee elementos similares al tratado educativo visto, y al igual que en este, los rasgos religiosos están ausentes.

Otros datos documentales abonan esta hipótesis. Claudio, general de Recaredo, fue retratado como un hombre temeroso de Dios, de una gran fortaleza física, un experto estratega y con una vasta experiencia militar. El mismo autor no dudó en describir al joven Witerico (el futuro rey) como un joven muy fuerte ${ }^{868}$. La inscripción funeraria destinada a recordar al noble Oppila ${ }^{869}$, quien encuentra su muerte en el campo de batalla, remarca de

\footnotetext{
${ }^{865}$ Ibidem, p. 235.

${ }^{866}$ LV, p. 370.

${ }^{867}$ ISID. Hist. Goth., "Recapitulatio", pp. 282-286.

${ }^{868}$ VSPE, p. 83.

${ }^{869}$ Ver p. 73.
} 
este guerrero su ilustre nacimiento, su riqueza, su incomparable fuerza y presencia. Moreno Resano distingue que en esta inscripción no hay mención a elementos de índole religiosa ${ }^{870}$.

También Eugenio de Toledo en uno de sus poemas inmortales quiso que se recuerde al aristócrata Nicolás de manera similar: como un hombre diestro en la guerra que cosechó magníficos triunfos sobre el enemigo

"Quisquis Romulidum fasces clarumque senatum

concelebrare cupis, quod veneris, habes.

si tibi bella placenta ut te prudentia mulcet, perfer ad hoc tumulum funeris obsequium.

Nicolaus ille, perpes quem fama loquetur

cuique reor similem saecula nulla ferent,

postquam magnificos gessit ex hoste triumphos,

dura sorte necis hic tumulatus inest

o felix vita! o mortis sententia dira!

sic vixisse placet, sic abiisse dolet" ${ }^{871}$.

“(...) Nobilis et magno virtutum culmine celse.

Ingens consiliis et dextrae belliger actu (...) ${ }^{\prime 872}$

Como señalamos antes, Isidoro alabó las cualidades militares de los reyes, pero no fue el único.

En este punto, aventuramos a afirmar que los elementos guerreros sobrepasaban la esfera de la ideología; eran elementos de la realidad que adquirieron su forma ideal. Las exigencias de la aristocracia (y de los ingenuos de menor condición) para con su rey se

\footnotetext{
${ }^{870}$ MoREnO ReSANO, E.: "La representación épica del combate y de la muerte del guerrero en el epitafio de Opilano (año 642)”, Habis 42, 2011, pp. 299-316. En palabras del autor: “(...) no alude (...) a los valores religiosos. En el caso de estos últimos, su expresión se reduce al signo de la cruz que encabeza el epitafio. (...) Esto implica que el epitafio de Opilano no desarrolla en su integridad la ética nobiliaria de la época, en particular relación con la guerra, pero, cuando menos, la selección de motivos que ofrece revela la importancia que tenían dichos valores en menoscabo de otros, al menos para la aristocracia bética de origen godo del siglo VII"

${ }^{871}$ EUG. Carm., p. 252.

${ }^{872}$ Idem.
} 
reflejaban en todo el programa ideológico construido para la legitimación regia. Ampliemos esta afirmación siguiendo los documentos.

Braulio de Zaragoza, junto a otro obispo, Eutropio, y el aristócrata Celso, en una carta enviada a Chindasvinto solicitaron — con el fin de prevenir situaciones políticas peligrosas y evitar las luchas por la sucesión al trono- que designase a su hijo como su sucesor, asociándolo. La argumentación se basó en las habilidades militares de Recesvinto, las cuales prometían estabilidad al reino:

“(...) que él, que tiene la edad adecuada para luchar y sobrellevar la fatiga de las guerras, pueda ser, con ayuda de la gracia divina, señor y defensor nuestro y descanso de vuestra serenidad, para que se apacigüen las amenazas de los enemigos y sus ofensas, y la vida de vuestros fieles permanezca segura, a salvo del miedo" ${ }^{\text {"873. }}$.

Recesvinto asumió el trono. Pasados unos años, los obispos reunidos en el Concilio de Toledo VIII (653), el primero celebrado por Recesvinto, lo reconocieron como el "señor de los ejércitos" y un "agradecido distribuidor de bienes" $" 874$. Los halagos dispensados a Recesvinto condensaban los elementos claves de un rey legítimo: el éxito en la guerra y su equitativa distribución de bienes entre la aristocracia. A la aristocracia no le importó alterar las reglas de la sucesión al trono, siempre que este consumase las expectativas aristocráticas. En el caso de Recesvinto, fueron cumplidas, sobre todo la distribución de bienes ${ }^{875}$. Entonces, la entrega de las recompensas en bienes materiales e intangibles por parte de los reyes fue un elemento definitorio en su relación con la aristocracia y con los hombres libres de menor condición.

Como enunciamos, los hombres de la Iglesia no fueron ajenos a la ideología guerrera, no rechazaron la importancia de los atributos militares de los reyes; al contrario, la

\footnotetext{
${ }^{873}$ BRAU. Ep.: epístola XXXVII, p. 149. Miguel Franco la enumera como la veintiocho. Seguimos la traducción de la autora, p. 149

${ }^{874}$ Concilios, Toledo VIII, año 653, c. C, p. 286. "Salus et benedictio ab exercituum Domino super serenissimum principem gloriosissimum: gratiarum action et reverentiae plenitude a nobis omnibus in commune ipsi clementissimo principi bonorum gratifico largitori (...)". "Salud y bendiciones por el Señor de los ejércitos sobre el serenísimo Recesvinto, rey gloriosísimo, acción de gracias, y plenitud de reverencia por todos nosotros en común para el mismo clementísimo príncipe, agradecido distribuidor de bienes (...)". Seguimos la traducción de Vives.

${ }^{875}$ Ver capítulo 5.
} 
magnificaron plasmándola en vehículos de propaganda que tuvieron como fin su inmortalización. Además, continuaron con la tradición que sostenía que la victoria militar la otorgaba Dios. Tema que retomaremos luego.

Hacia el 653, Tajón de Zaragoza escribió una carta dirigida a Quírico de Barcelona ${ }^{876}$. En ella relata que buena parte de la zona del Ebro estuvo ocupada por los vascones en alianza con un caudillo de origen godo, de nombre Froya, quien aspiraba a ocupar el trono. La sublevación llegó a sitiar la ciudad de Zaragoza, causando los males de la guerra a la población (saqueos, cautivos). Recesvinto en persona dirigió el ejército que aplastó la rebelión, Tajón lo nombró como el “Misso igitur caelitus propugnatore fortissimo" ${ }^{877}$. Según M. C Díaz y Díaz, ${ }^{878}$ esta campaña militar inspiró el Ymnus de profectione exercitus qui usque in reuersione dicendus est diebus letaniarum, elaborado para ser cantado en la ceremonia que despedía al ejército que partía a la guerra. En este himno se recordó la ferocidad de los vascones, se aludió a un levantamiento y se pidió a Dios que concediese la victoria permanente a los reyes ${ }^{879} \mathrm{y}$, como consecuencia, la paz.

Asimismo, la figura del rey guerrero fue celebrada por la Iglesia católica a través de ritos litúrgicos. El Ordo quando rex cum exercitu ad prelium egreditur, el más destacable por sus elementos, constituye una serie de ritos y oraciones a realizar ante la partida del ejército regio hacia la guerra ${ }^{880}$. El Liber Ordinum establece que el rey entre a la iglesia recibido por dos diáconos vestidos de blanco que estando de pie le ofrezcan el incienso; el rey, postrado, en silencio reza por la protección suya y de su ejército. Luego, el obispo en su oración evoca a Dios “el propagador de victorias” 881 para que concediese al rey: “(...) exercitus fortes, duces fidos, concordes animos, quo ualeat uirtute superare aduersos, ualitudine defendere suos, expugnare aduersa, defendere propia. (...)”882. Luego se le

\footnotetext{
876 TAJ. Sent., pp. 171 y 172.

${ }^{877}$ Ibidem, p. 172. Nótese que Tajón de Zaragoza escribió de forma muy abreviada los sucesos (dos páginas en la versión editada), pero no dejó de alabar una cualidad regia de naturaleza guerrera.

878 DíAZ Y DíAZ, M.C: "Noticias históricas en dos himnos litúrgicos visigodos", Los Visigodos. Historia y civilización Antigüedad y Cristianismo, III, Murcia, 1986.

${ }^{879}$ Díaz y Díaz sostiene que se utiliza el término "reyes" en plural porque el himno se realizó en la corregencia de Chindasvinto y Rescesvinto. Ibidem, p. 447.

${ }^{880}$ Existen otras dos ceremonias registradas en el Liber Ordinum: Orationes de regressu regis y De susceptione regis quando de vicino regreditur: la primera celebra el regreso victorioso del rey y la segunda el regreso seguro desde los territorios vecinos. En ambas situaciones el peligro es inexistente. Lib. Ord., pp. 154 y 155.

881 "propagator uictoriarum"

${ }^{882}$ Ibidem, p. 150 y 151.
} 
presenta al rey una cruz de oro que contiene una astilla perteneciente a la cruz de Cristo, la cual será trasportada lo que dure la campaña militar. El final de la ceremonia llega cuando el obispo recita una larga bendición cuyos versos reflejan la esperanza de un regreso triunfal y la paz consiguiente. Se realizan las fórmulas de despedidas, el rey monta su caballo y parte con su ejército. Sabemos que estas series de ritos no fueron letra muerta. El ceremonial de despedida tiene su correlato en el Concilio provincial de Mérida celebrado en el año 666. Los obispos allí reunidos propusieron un oficio religioso con el objeto de obtener la victoria por intercesión divina, y para que se conservase la vida del rey y de todo el ejército y súbditos en guerra $^{883}$

Destacamos la cita seleccionada del ritual de despedida del rey y su ejército ${ }^{884}$ porque allí se puntualizó que el rey para triunfar debía recibir el favor divino, pero también contar con elementos de índoles terrenales: ejércitos fuertes, duques fieles y voluntades concordantes. Todos aspectos que hemos ido analizando a lo largo de esta tesis y que encontramos condensados en esta oración litúrgica.

Por último, resta ver otro elemento que exaltó por igual los aspectos religiosos y guerreros: las monedas.

El aporte de la numismática al estudio de la legitimidad regia visigoda es fundamental por la importancia que tuvieron las monedas como vehículos de ideas y propaganda ${ }^{885}$. Las estampas y leyendas monetarias transmitían el código político-ideológico del poder emisor, proyectaban la imagen de la autoridad no solo hacia la aristocracia, sino también hacia las clases productoras. Varios son los aspectos analíticos de las monedas que nos interesan en esta oportunidad: la procedencia, es decir la ceca, la leyenda y la imagen ${ }^{886}$, que trabajaremos a través de algunos ejemplos.

Leovigildo fue el primer rey que acuñó moneda propia; y en su lucha contra su rebelde hijo Hermenegildo se hizo evidente el propósito de esa empresa ${ }^{887}$. En sus monedas se

\footnotetext{
${ }^{883}$ Concilios: Mérida, año 666, c. III, p. 327.

884 Ya la había destacado MCCORMICK, M.: Eternal Victory, p. 325.

${ }^{885}$ Dice Pliego Vázquez. “(...) cabe la posibilidad de que el tremis visigodo se convierta a medida que avanzaba el Reino de Toledo en un producto más dentro del conjunto de los bienes de prestigio involucrados en los intercambios entre los potentes". Pliego VÁZQUEZ, R.: La moneda visigoda, tomo I, p. 228. Coincide con este argumento: SÁNCHEZ PARDO, J. C.: "Sobre las bases económicas de las aristocracias en la Gallaecia suevovisigoda (ca. 530-650 d.C). Comercio, minería y articulación fiscal”, p. 1006.

${ }^{886}$ Todas las monedas son estudiadas desde PLIEGO VÁZQUEZ, R.: La moneda visigoda, tomo II.

${ }^{887}$ Pliego VÁzQUeZ, R.: La moneda visigoda, Tomo I, p. 91.
} 
marcaron las victorias militares obtenidas con ayuda divina: Pius Emerita Victor, Emerita Victoria, Cum Deo Italica, Cum Deo Roda ${ }^{888}$. La práctica de estampar las victorias militares no se circunscribió a Leovigildo, su hijo Recadero también lo hizo ${ }^{889}$. Sisebuto en el 619 celebró la caída de la ciudad de Barbi con una serie de monedas con la leyenda ictor $^{890}$. Una moneda con el nombre del rey Wamba junto a un tipo de cabellera y la leyenda Tarraco Pius se acuñó luego de vencer al rebelde Paulo en Narbona ${ }^{891}$. Asimismo, Witiza tuvo su serie monetaria asociada al título Victor proveniente de la ceca de $\mathrm{Acci}^{892}$, la cual conmemoraría, según López Sánchez, a un ataque defensivo exitoso contra fuerzas bizantinas. ${ }^{893}$ De hecho, señala este autor, que

“(...) la gran producción acuñadora que todos los reyes visigodos posteriores a Suintila $<621-631>$ tuvieron en ciudades como Acci, Eliberri, Iliocrici, Mentesa, Beatia, Castelona, Valnetia o Sagunto debe ligarse entonces con guarniciones vigilantes en lugares sensibles para el poder regio". 894

La relación de las cecas y la leyenda Victor debe ser entendida como hitos de batallas exitosas donde se afirmaba el poder regio sobre los territorios vencidos y conquistados, y como un monumento móvil que recordase por siempre a quien hizo posible esa victoria: el rey como el líder del ejército que recibió la ayuda divina por ser el elegido de Dios. La misma idea que hemos visto en la ceremonia de la entrega del estandarte en forma de cruz al inicio de las campañas militares.

Otro aspecto para destacar de las monedas es la imagen de los reyes en sus sellos. Velázquez, Barroso y Morin de Pablos, utilizando la tipología establecida por Heiss ${ }^{895}$ para

\footnotetext{
${ }^{888}$ Ibidem, pp. 55-78.

${ }^{889}$ Por ejemplo, las monedas 149 y 150 de PLIEGo VÁzQUeZ, R.: La moneda visigoda, tomo II, p. 118.

${ }^{890}$ Ibidem, p. 172. La leyenda dice: SISEBUTUSRE / VICTORB: $\Lambda$ RBI (moneda 268)

${ }^{891}$ Ibidem,p. 368, moneda 614. 1.

${ }^{892}$ Ibidem, p. 470, moneda 767.1.

${ }^{893}$ LÓPEZ SÁNCHEZ, F: “La moneda del reino visigodo en Toledo: ¿Por qué? ¿Para quién?”, Mainake, ISSN 0212-078X, Nº. 31, 2009, pp. 175-186.

${ }^{894}$ Ibidem.

${ }^{895}$ Aloïse Heiss estableció seis tipos de monedas distintas. Para su clasificación tuvo en cuenta los anversos. HeISS, A.: Description génerale des monnaies des rois wisigoths d'Espagne, París, 1872. Pliego Vázquez establece tres grandes tipos que contienen subtipos por región y motivos. PLIEGO VÁzQUEZ, R.: La moneda visigoda, cap. IV
} 
las monedas visigodas, observan que los tipos I, II y IV muestran un busto regio coronado con diadema y paludamentum (manto o capa militar, imitan al modelo bizantino). El tipo V es una simplificación de la imitación de las monedas de Justiniano I y Justino. El tipo III muestra tanto en los anversos como en los reversos dos bustos enfrentados que visten una coraza. En algunas series de monedas la cabeza del rey está coronada con un yelmo con diadema (por ejemplo las acunaciones de Wamba) y algunos sostienen un estandarte con la cruz. Esta imagen estaría representando al rey comandando al ejército, tal como es descripto en el himno que pide por el éxito militar. Estos autores no dudan en afirmar que “(...) la imagen del soberano ataviado con el yelmo y la cruz parece responder a la idea del monarca como jefe supremo de la milicia (...)"\$966. También López Sánchez observa que los elementos iconográficos encontrados en los testimonios numismáticos transmiten la imagen de una realeza guerrera ${ }^{897}$. Ampliando la tipografía, Pliego Vázquez coincide con los autores, aunque es más detallista y, como consecuencia, amplia el número de tipos de monedas ${ }^{898}$.

Llegados a este punto advertimos que uno de los puntos centrales de los documentos analizados es la concesión de la victoria a los reyes por parte de Dios. Este problema fue largamente estudiado por McCormick ${ }^{899}$, entre otros, quien enfatizó sobre la liturgia de la guerra en clave cristiana desde la conversión al cristianismo de Constantino ${ }^{900}$. Entre los miembros más encumbrados de los visigodos, al igual que entre los francos, la conversión al cristianismo fue exitosa por la promesa de la victoria por parte de los propagadores de la religión. El caso de Clovis es paradigmático: se convirtió al cristianismo luego de vencer a los alamanes bajo la protección del Dios de la reina (año 496) ${ }^{901}$.

Teniendo en cuenta esto, y luego de la exposición documental, se comprende mejor la existencia de un núcleo de sentido invariante laico-guerrero que fue hegemónico, universal y compartido, expresado en diferentes medios, incluso en los discursos eclesiásticos. El discurso tuvo el potencial de reunir a los hombres libres bajo el liderazgo del rey.

\footnotetext{
${ }^{896}$ Barroso Cabrera, R., Morín de Pablos, J. y Velázquez Soriano, I, op. Cit..

${ }^{897}$ LÓPEZ SANCHEZ, F.: "Reges Criniti Visigothorum", Revue numismatique, nº 6, 158, 2002. pp 241-269.

${ }^{898}$ PLIEGo VÁzQUEZ, R.: La moneda visigoda, tomo I, cap. IV.

${ }^{899}$ MCCORMICK, M.: Eternal Victory, pp. 297 y ss.

${ }^{900}$ Sobre Constantino ver: Collins, R.: La Europa de la Alta Edad Media, Madrid, Akal, 2000, pp.47 y ss.

${ }^{901}$ Castellanos, S.: "Creating new Constantines at the end of the sixth century", Historical Research, 85 (230), p. 559, 2012.
} 
Otro elemento que está presente de forma constante como elemento de legitimidad vinculado a la guerra (ya destacado por Isidoro y citado) es el justo reparto de bienes, aspecto abordado en los capítulos anteriores tocantes al reparto de premios. Los reyes, como hemos visto, debían entregar premios y mercedes, mostrarse generosos con los aristócratas y los ingenuos de menos condición para ganar y conservar su fidelidad. Fue una estrategia privilegiada utilizada para la creación de las redes políticas.

El compendio litúrgico supera el mero marco discursivo, siendo al contrario

elementos de legitimación concretos del poder regio. Fueron elementos reales que encontraron su espacio en lo ideal, que lo abonaron y potenciaron, constituyéndose en un marco de referencia de las expectativas aristocráticas y de los guerreros que seguían al rey. El ethos guerrero constituyó el núcleo del carisma regio. Y como elemento carismático, fue un elemento volátil.

\section{CONCLUSIONES GENERALES}


Las siguientes páginas tiene como finalidad presentar un compendio con las conclusiones a las que hemos arribado a lo largo nuestra investigación; nos detendremos en ciertos aspectos que concebimos medulares para caracterizar al poder regio visigodo del largo siglo VII.

Esta investigación se inició con una pregunta que se originó en las largas sesiones de lectura de los documentos provenientes del reino godo, que planteamos de la siguiente manera: ¿cómo explicar el aumento y disminución de forma alternativa de la intensidad del poder político regio? Teníamos ante nosotros un problema histórico complejo, que a simple vista no tenía solución posible. Una forma de resolver este dilema hubiese sido desestimar alguna de las variables, reducir su significado para así anular su entidad como factor de peso en el momento de entender el problema planteado. Sin embargo, nuestro principal propósito consistió en elucidar la oscilación del poder político regio sin omitir ni desestimar los elementos documentales que percibíamos contradictorios. Este objetivo lo cumplimos ya que recurrimos a conceptos teóricos para desentrañar el fárrago documental al cual nos enfrentábamos.

Luego del análisis bibliográfico y documental, advertimos que el reino visigodo de Toledo del largo siglo VII debía examinarse como una unidad, como un todo. Más allá de las marcadas diferencias regionales — sobre todo en el aspecto económico_-, creemos necesario destacar que este enfoque es ineludible puesto que los reyes intentaron gobernar sobre toda la Península Ibérica. En su proyecto las fronteras políticas estuvieron debidamente delimitadas; ahora bien, que el control efectivo sobre lo que consideraban su territorio por el derecho de conquista fuese imperfecto constituye otra cuestión. Esta constatación derivó en la búsqueda de un marco referencial propicio para interpretar el comportamiento de la realeza en sociedades como la visigoda.

Hemos visto que el reino visigodo fue una sociedad donde imperaba la inestabilidad política, su génesis la encontramos en la debilidad de las bases económicas de la aristocracia y en la no cristalización de las relaciones políticas desiguales. La comprensión de estos fenómenos derivó en el análisis del concepto de modo de producción campesino propuesto por Wickham, la noción de formación social y elementos provenientes de la tradición weberiana; volveremos sobre esto último más adelante. Las lecturas sobre estos problemas brindaron un conjunto de elementos teóricos que nos permitieron afirmar que el reino 
visigodo fue una formación social de base campesina; las relaciones de dependencia y de poder predominantes fueron más laxas que coercitivas, y la aristocracia se enfrentaba a una fase de contracción de su poder político y económico — su radio de dominación fue restringido-, dejando espacios para una organización autónoma del campesinado. Esto no implicó desconocer otras formas de explotación opresivas, coexistentes en este mismo espacio temporal. Como destacamos, el uso de la noción de formación social como encuadre analítico habilita la conjugación de elementos contradictorios de la realidad, evitando así la elaboración de un discurso que carezca de lógica.

Con respecto a la relación social establecida entre los reyes y la aristocracia, observamos que estuvo signada por la lógica de la reciprocidad. Los vínculos de esta naturaleza fueron de muta interdependencia, cooperativos y competitivos, pero no antagónicos. Estuvieron mediados por la entrega de recompensas y bienes — tangibles e intangibles (como los cargos palatinos) - y el intercambio de apoyo político y fidelidad. Los reyes se comprometían a entregar a la aristocracia riquezas que se convertirían en beneficios condicionados por su lealtad; también le brindaban un lugar en el poder central, una posición en la corte regia, prestigio, privilegios y prerrogativas. A cambio, la aristocracia que había prometido a los reyes su fidelidad debía apoyo político y servicios militares. El juramento de fidelidad no fueron palabras vacías, se erigió como una pieza fundamental del engranaje político.

La aristocracia se relacionaba con la realeza en busca de beneficios y legitimación. Este intercambio de bienes con fines políticos originaba lazos solidarios, así como generaba competiciones y conflictos, ya que si una parte rompiese con lo prometido la relación social podría deshacerse. Este vínculo era frágil, fácil de romper; la naturaleza de esta relación social fue laxa, más horizontal que vertical.

Sin embargo, debido a la lógica que presidía esta relación, la capacidad de agencia política y económica aristocrática no se supeditó a los deseos de los reyes; al contrario, la aristocracia conservaba una fuerte autonomía y luchaba por conservarla. A pesar de la diferencia de estatus que el puesto regio confería y sus prerrogativas, la cristalización de estas relaciones desiguales, su objetivación, no sucedió. Los reyes y la aristocracia pertenecieron a una misma clase dominante; las disputas por la hegemonía política se materializaban en los 
conflictos por el control del trono. Las fracciones aristocráticas se encontraban en un equilibrio inestable.

La lógica del regalo dinamizaba la política visigoda. Los mecanismos de entrega de premios y recompensas impactaron de forma negativa sobre los bienes que controlaban los reyes. Antes de seguir, recordemos que el volumen de riquezas regias conservó un carácter restringido, que se vio afectado por el escaso desarrollo de las fuerzas explotativas y las dificultades a las cuales se enfrentaba el erario. Por lo tanto, la redistribución de los beneficios en un contexto de escasez económica introducía condiciones políticas muy volátiles y estimulaba la competencia por los bienes que los reyes, por sus prerrogativas, controlaban. Asimismo, los máximos jefes del reino, ante el faltante de recursos, activaban el mecanismo de confiscación que impulsaba la lógica de arrebatar los bienes de sus enemigos y ofrecérselos a sus aliados, y esperaban que retornase como apoyo político. El intercambio de dones tuvo como resultado que los bienes que ingresaban al arca regia transitasen en manos de la realeza temporalmente; la patrimonialización de las riquezas fue bloqueada.

Destacamos que la violencia ejercida contra las figuras regias constituyó un fenómeno estructural de la dinámica política, fue un elemento constante de la política visigoda, orgánico, que no se limitaba a los reinados “débiles”. La fracción aristocrática que gobernaba no tenía el monopolio de la violencia ni el control sobre los guerreros que mantenían lazos especiales con sus enemigos.

La oscilación del poder regio, la fragilidad institucional, los conflictos por el poder recurrentes y la precariedad de las bases materiales fueron elementos que sumados nos permiten aseverar que la característica principal del poder regio fue su inestabilidad, expresión que sintetiza su esencia. El uso de las formulaciones weberianas sobre el problema de la dominación nos posibilitó llenar de contenido al término inestable, sin que sea posible intercambiarlo por alguno de sus sinónimos.

La dominación inestable posee como rasgo principal la posibilidad de rechazar la legitimidad de la autoridad. Esto nos llevó a plantear que los elementos que elevaban a un miembro de la aristocracia al cargo de rey debían ser legítimos frente al conjunto aristocrático, y no siempre se correspondían con las disposiciones legales laicas y/o eclesiásticas. 
Estas definiciones revelan cómo es posible la convivencia de distintas formas de acceso al trono. La asociación, la elección y la usurpación constituyeron vías legítimas de conseguir la corona, mas no todas fueron legales. En la práctica, los reyes — sin importar la forma en que ocupaban el trono - estaban obligados a legitimarse ante la aristocracia a través de distintos mecanismos.

La dominación inestable se constituye en un sintagma cargado de definiciones que explican la dinámica política regia. El término inestable, leído en la clave propuesta, descubre los ciclos oscilantes del poder regio como partes de una misma dinámica que contempla la posibilidad de la fragmentación de la lealtad política. Los momentos conflictivos y de debilidad regia no son interpretados como disruptivos, sino como fases lógicas de un proceso. De hecho, hemos comprobado que hubo reyes exitosos. Esto nos condujo a reflexionar sobre los dispositivos que legitimaban a un rey en una sociedad inestable.

Destacamos el factor militar en el juego político. Los reyes se vieron obligados a posicionarse como los mejores guerreros, los líderes que reportasen las más cuantiosas oportunidades para sus seguidores, que incluían no solo a la aristocracia sino también a los ingenuos. El examen sobre la organización y la composición social de las huestes dieron como resultado que las relaciones de subordinación entre la aristocracia y sus guerreros estaban mediadas por recompensas, y este vínculo podría disolverse fácilmente. La lógica de la reciprocidad lo tutelaba.

La generosidad fue una cualidad que se convirtió en vehículo de la construcción de la autoridad de los reyes. A través del reparto equitativo y justo los líderes cimentaban sus relaciones de dominación, aunque estas se caracterizasen por su laxitud y su precariedad. La entrega de bienes implicó la destrucción de las riquezas en el sentido que se ha planteado desde la antropología.

La exaltación del carácter militar fue un elemento destacado de la ideología que legitimaba a los reyes en su posición privilegiada. Como hemos visto, la aristocracia adoptó una identidad militar, sus expresiones se vinculan con los valores guerreros. La propaganda y los discursos divulgados por la Iglesia y los laicos estaban imbuidos del ethos guerrero, que reflejaba las expectativas sociales aristocráticas. Esto no equivale a desconocer la figura del rey como príncipe religioso, sino que proponemos que este último aspecto fue subordinado 
por los elementos vinculados con la guerra, que en última instancia constituyeron el carisma regio.

Los reyes visigodos ambicionaron gobernar a lo largo de la Península Ibérica, mas solo lo lograron aquellos que construían permanentemente su poder, aquellos que descubrimos en una perpetua negociación de su estatus.

\section{BIBLIOGRAFÍA}

\section{Primaria}


Brau. VSE: Braulio Caesaraugustanus: Vita Sancti Aemiliani, ed. J. Oroz, "Vita sancti Aemiliani. Hymnus in festo sancti Aemiliani abbatis", Perficit, 9, 119-120, 1978.

Brau. Ep.: Braulio Caesaraugustanus: Epistularium, ed. L. Riesco Terrero, Epistolario de San Braulio. Introducción, edición crítica y traducción, Sevilla, 1975. Véase también trad. R. Miguel Franco, Braulio de Zaragoza. Epístolas, Akal, 2015.

Chron. Caesarag.: Chronicorum Caesaraugustanorum reliquiae, ed. Th. MoMMSEN, MGH, Aa, XI, Berlín, 1961 (=1894), pp. 221-223.

Chronica muzarabica anni 754: ed. J.E. LÓPEZ PEREIRA, J, Crónica mozárabe de 754. Edición crítica y traducción, Anubar Ediciones (Col. Textos Medievales 58), Zaragoza, 1980 .

Chron. Rot.: Crónicas asturianas. Crónica de Alfonso III (Rotense y "A Sebastían”). Crónica Albeldense (y "Profética”). Introducción y edición crítica de. J. GIL FERNÁNDEZ. Traducción y notas de J. MorAlEJO. Estudio preliminar de J.I. RUIZ DE LA PEÑA, Oviedo, 1985.

Cod. Eur.: Codex Euricianus, ed. A. D’orS, El código de Eurico. Edición, Palingenesia, Índices (Estudios visigóticos II), Roma, Madrid, 1960.

Colección Canónica Hispana, ed. G. Martínez DíEz y F. Rodríguez, IV, Concilios hispano: Primera parte, Madrid, 1984; V. Concilios hispanos: Segunda parte (Hasta X Toledo), Madrid, 1992.

Concilios: Concilios visigóticos e hispanos-romanos, ed. J. VIVES, Barcelona, Madrid, 1963. Ep. Wis.: Epistulae Wisigothicae, ed. J. GIL, Miscellanea Wisigothica, Sevilla, 1972.

Eug. Carm.: Eugenit Toletani EPISCOPI, Carmina et epistulae, ed. F. Vollmer, MGH, Aa, vol. 14, Berlín, 1905.

Fredeeg. Chron.: Fredegari (PSEudo), Chronicarum libri IV, cum continuationibus, ed. B. KRUSCH, MGH, Scriptores Rerum Merowingicarum, II, Hannover, 1888, pp. 18-93.

Greg. MAG. Ep.: Gregorius Magnus, Registrum epistularum, ed. L.M HARTMANN, MGH, Epist. I-II, Berlin, 1957.

Greg. Mag. Diag.: Gregorius Magnus, Dialogi, ed. A. DE VogüÉ, en Sources Chétiennes, París, 1978-1980. 
Greg. Tur. Hist. Franc.: GregoriI EpISCOPI Turonensis, Historiarum Libri X (Historia

Francorum), ed. B. KRUSCH y W. LEVISON, MGH, Scriptores Rerum Merowingicarum, 1, Hannover, 1951. Veáse también Trad. L. THORPE, The history of the franks. Londres, 1974.

ICERV: Inscripciones cristianas de la España romana y visigoda, ed. J. VIVES, J.: Inscripciones cristianas de la España romana y visigoda, Barcelona, 1947.

ILD. TOL. De vir. Illustr.: IDELFUnSUS TOLETANIS: De viris illustribus, ed. C. CODOÑER MERINO, El $<$ De viris Illustribus $>$ de Idelfonso de Toledo. Estudio y edición crítica, Salamanca, 1972.

IOHAN Bicl. Chr.: IOHANnis BiClarensis: Chronicon, ed. C. CARDElle DE Hartman y R. Collins, Corpus Christianorum Series Latina, 115, Turnhout, 2001.

ISID. De vir. Illustr.: IsIDORUS HiSPALENSIS: De viris illustribus, ed. C. C. CODOÑER MERINO, El $<$ De viris illustribus $>$ de Isidoro de Sevilla. Estudio y edición crítica, Salamanca, 1964.

IsID. Hist. Goth.: IsIDORUs HisPalensis: Historia Gothorum, ed. C. RodRíGUEZ, Alonso, Las historias de los Godos, Vándalos y suevos de Isidoro de Sevilla, León, 1975.

ISID. Etymologiae: IsIDORUS HisPalENSIS: Etymologiae, ed. J. OROZ RETA Y A. MARCOS CASQUERo (eds. y trads.), San Isidoro de Sevilla. Etimologías, Madrid, 2004.

ISID. De ortu et obitu Patrum: ISIDORUS HISPALENSIS, De ortu et obitu Patrum, ed. y trad.

C. Chaparro Gómez, C. Vida y muerte de los santos. París, Les Belles Lettres, 1985.

Iul. Tol. HW: Iuliani Toletani EPISCOPI, Historia Wambae, ed. W. LeViSnON, Corpus Christianorum Series Latina, 115, Turnhout, 1971.

Lat. Reg. Vis.: Laterculus Regum Visigothorum, ed. TH. MoMmSEN, MGH, Aa, XIII, Berlin, 1898, pp. 464-469.

LV: Lex Visigothorum, ed. K. ZEUMER, MGH, Legum sectio I, Leges nationum germanicarum I, Hannover, Leipzig, 1902. También: GARCÍA LÓPEZ, Y.: Estudios críticos y literarios de la "Lex Wisigothorum", Universidad de Alcalá, 1996.

Lib. Ord.: Le liber ordinum, ed. M. Ferotin, MEL, v. 5, París, 1904.

Pauli Diaconi, HL: Pauli Diaconi, Historia Langobardorum, ed. BethMan, L.; Waitz, G., MGH, Sriptores rerum Langobardicarum et Italicarum saec. VI-IX, Hannover, 1878 (1988), pp. 45-187. Véase también trad. PABlo DiÁCONO, Historia de los Longobardos, introducción, traducción y notas de Pedro Herrera Roldán, Universidad de Cádiz, 2006. 
Procopio de Cesarea: De bello Gothico, ed. J. A. Flores Rubio, Guerra gótica V-VI. Introducción, traducción y notas, Editorial Gredos: Madrid, 2006.

TACITUS, Germ: TACITUS: De vita Iulii Agricolae, de origine et morubus Germanorum, ed. J.H. SLEEMAN, University Press, Cambridge, 1933

Taj. Sent.: Tajonis Caesarugustani Episcopi: Sentetiarum, ed. M. Risco, España Sagrada, 31, Madrid, 1776.

VAl. Ord.: VAlERIUS Bergidensis: Ordo querimonie prefati discriminis, ed. M.C. DÍAZ Y DíAZ, Valerio del Bierzo. Su persona. Su obra, León, 2006, pp. 246-277.

VAL. Replic.: VALERIUS BERGIDENSIS: Replicatio sermonum a prima conuersione, Ibid., pp. 280-311.

VAL. Quod de super: VALERIUS BERGIDENSIS: Quod de superioribus querimoniis residuum sequitur, Ibid, pp. 312-323.

Vit. Fruct.: Vita Sancti Fructuosi, ed. M.C. DÍAZ y DÍAZ, La vida de San Fructuoso de Braga. Estudio y edición crítica, Braga, 1974.

VELÁZQUEZ SORIANO, I.: Las pizarras visigodas: edición crítica y estudio, Universidad de Murcia, Secretariado de Publicaciones, 1989.

VSPE: Vitas Sanctorum Patrum Emeretensium, A. MAYA SÁNCHEZ, Vitas Sanctorum Patrum Emeretensium, Corpus Christianorum Series Latina, 116, Turnhout, 1992. Véase también Vidas de los Santos Padres de Mérida. Introducción, traducción y notas de Isabel Velázquez, Editorial Trota, Madrid, 2008.

\section{Secundaria}

Airlie, S.: “The aristocracy”, en MCKITTERICK, R. (ed.): The New Cambridge Medieval History, Cambridge: University of Cambridge, 1995.

Althoff, G.: "Las amicitiae [amistades] como relaciones entre estados y pueblos", en

Little, L. K y Rosenwein, B.H. (ed.): La Edad Media a debate, Madrid: Akal, 2003, pp. 304-333.

Alvarado Planas, J.: “A modo de conclusiones: el Liber Iudiciorum y la aplicación del Derecho en los siglos VI a XI”, Mélanges de la Casa de Velázquez, 41-2, 2011.

Alvarado Planas, J.: El problema del germanismo en el Derecho español. Siglos V-XI, Madrid: Marcial Pons, 1997. 
AMORY, P.: "The meaning and purpose of ethnic terminology in the Burgundian laws", Early Medieval Europe, 1993, vol. 2, 1, p. 1-28.

Aronso, P.: "La centralidad del carisma en la sociología política de Max Weber", Entramados y perspectivas. Revista de la carrera de sociología, vol. 1, 1, enero-junio 2011, pp. $10-126$.

Astarita, C.: "La primera de las mutaciones feudales", Anales de Historia Antigua y Medieval y Moderna, 2000, Vol.33, pp 75-106.

Astarita, C.: "Prácticas del conde y formación del Feudalismo: siglos VIII al XI", Anales de la Universidad de Alicante: Historia medieval, 14, 2003-2006, pp.21-52.

AstaritA, C.: “Construcción histórica y construcción historiográfica de la temprana Edad Media”, Studia Histórica, Historia Medieval, Salamanca, 2007, 25, pp 247-269.

Astarita, C.: "Visiones nacionales en el medievalismo", Anales de Historia Antigua, Medieval y Moderna, Buenos Aires, 2008, vol. 40, pp. 119-150

ARCE, J.: “Ceremonial visigodo/ < bizantino>. Un tópico historiográfico”, en PÉREz MARTíN, I. Y BÁdenAs De LA PEÑA, P. (eds.): Bizancio y la Península Ibérica. De la antigüedad tardía a la edad moderna, Madrid: Nueva Roma 24, 2004, pp. 101-115.

ARCE, J.: Esperando a los árabes: Los visigodos en Hispania (507-711), Madrid: Marcial Pons. Historia, 2011.

ARIÑO, E.: "El hábitat rural en la Península Ibérica entre finales del siglo IV y principios del VIII: un ensayo interpretativo", Antiquité Tardive, 21, 2013.

AA.VV.: "Le droit hispanique latin du VIe au XIIe siècle", Mélanges de la Casa de Velázquez, 41-2, 2011.

AA.VV.: Symposium 1, 2016-2017: Law and Theology, Networkd and Neighbors, online: https://visigothicsymposia.org/symposia/.

AlgazI, G.; Groebner, V.; Jussen, B. (ed.): Negotiating the gift: Pre-Modern Figurations of Exchange, Alemania: Vandenhoeck \& Ruprecht, 2003.

AzKarate Garai-Olaun, A. \& Quirós CAstillo, J.A.: "Arquitectura doméstica altomedieval en la Península Ibérica. Reflexiones a partir de las excavaciones arqueológicas de la Catedral de Santa María de Vitoria-Gasteiz, País Vasco”, Archeologia Medievale, 28, 2001. 
AzzARA, C.: Las invasiones bárbaras, Valencia: Universidad de Granada y Universitat de València, 2004.

BARBERO, A.: "El pensamiento político visigodo y las primeras unciones regias en la Europa medieval", Hispania, 115, 1970.

Barbero, A. \& Vigil, M.: La formación del feudalismo en la Península Ibérica, Barcelona: Crítica, 1978.

BARNISH, S.J.B.: "Taxation, Land and Barbarian Settlement in the Western Empire", Papers of the British School at Rome, 54, 1986.

BARCELÓ, M.: “Les plagues de llagost a la Carpetania, 578-649”, Estudis d'história agraria, 1, 1978, pp. 67-84.

BARCELÓ, M.: “Arqueología e historia medievales como historia”, en Quirós CASTILLO, J. A. (eds.): La materialidad de la historia: la arqueología en los inicios del siglo XXI, 2013. Barroso Cabrera, R. y Morín de Pablos, J: "Imagen soberana y unción regia en el reino visigodo de Toledo", Codex Aquilarensis, 20, 2004.

Barroso Cabrera, R., Morín de Pablos, J. y Velázquez Soriano, I.: "La imagen de la realeza en el reino visigodo de Toledo a través de la iconografía y la epigrafía”, Zona arqueológica, 11, 2009.

BlANCO GonZÁLEZ, A.: "Espacios residenciales y productos del interior peninsular entre la Antigüedad Tardía y la Alta Edad Media. Propuestas desde la arqueología extensiva”, en MARTín Viso, I. (ed.): ¿Tiempos oscuros? Territorio y sociedad en el centro de la Península Ibérica (siglos VII-X), Madrid: Sílex, 2009.

BONNASSIE, P.: "Supervivencia y extinción del régimen esclavita en el occidente de la alta Edad Media (siglos IV-XI)", en BonNassie, P.: Del esclavismo al feudalismo en Europa occidental, Barcelona: Crítica, 1991.

BONNASSIE, P.: "El señorío banal y los cambios en la condición del campesinado libre", en Little, L.; Rosenwein, W., (eds.), La Edad Media a debate, Madrid, Akal, 2003, p. 190218.

Boserup, E.: Las condiciones del desarrollo en la agricultura. La economía del cambio agrario bajo la presión demográfica, Madrid: Editorial Tecnos, 1967. 
Bowlus, CH.: "Ethnogenesis: the tyranny of a concept". On Barbarian Identity. Critical Approaches to Ethnicity in the Early Middle Ages, Turnhout: Brepols Publishers, 2002, pp.241-256.

Brogiolo, G.P.: “<Aristocrazie e champagne $>$ " a una arqueología de los paisajes medievales", en Caballero Zoreda, l., Mateos Cruz, P. y Cordero Ruiz, T. (eds.): Visigodos y Omeyas. El Territorio, Anejos de Archivo Español de Arqueología, 61, Madrid: CSIC, pp. 9-20.

Bronisch, A. P.: Reconquista y guerra santa. La concepción de la guerra en la España cristiana desde los visigodos hasta comienzos del siglo XII, Granada: Universidad de Oviedo, 2006.

BRONISCH, A.P.: "Precisiones sobre algunas informaciones históricas en la $<$ Crónica de Alfonso III>”, Edad Media. Revista Histórica, 12, 2011, p. 35-66.

Castellanos, S.: Poder social, aristocracias y "hombre santo" en la Hispania visigoda: la "vita aemiliani" de Braulio de Zaragoza, Logroño: Universidad de La Rioja, 1998.

Castellanos, S.: "The political nature of taxation in Visigothic Spain", Early Medieval Europe, vol. 12, 2003, pp. 201-228.

CAstellanos, S.: Los godos y la cruz: Recaredo y la unidad de Spania, Madrid: Alianza, 2007.

Castellanos, S.: "Creating new Constantines at the end of the sixth century", Historical Research, 85 (230), pp. 556-575, 2012.

Castellanos, S., y Viso, I. M.: "The local articulation of central power in the north of the Iberian Peninsula (500-1000)", Early Medieval Europe, 2005, 13(1), pp. 1-42.

CAStro, D.: "Modelos bíblicos para reyes visigodos: un estudio a partir de las Sentencias de Isidoro de Sevilla", Espacio, Tiempo y Forma, Serie III Historia Medieval, 28, 2015, pp. 255-273.

CASTRO, D.: Palabras inmortales: poder, autoridad y exégesis bíblica en el reino visigodo de Toledo (589-711), Tesis doctoral, 2017.

CAZIER, P.: "Les Sentences d'Isidore de Séville et le IVeConcile de Tolède. Réflexions sur les rapports entre l'Eglise et le pouvoir politique en Espagne autour desannées 630", Los visigodos. Historia y civilización. Antigüedad y Cristianismo 3, Murcia, 1986. 
Chavarría ArnaU, A.: El final de las uillae en Hispania (siglos IV-VIII), BAT 7, Turnhout: Brepols Publishers, 2006.

Chavarría ArnaU, A.: "Interpreting the Transformation of Late Roman Villas: The case of Hispania”, en CHRISTIE, N. (ed.): Landscape of Change. Rural Evolution in Late Antiquity and the Early Middle Ages, Inglaterra: Ashgate Publishing Company, 2004.

Chavarría Arnau, A.: “¿Castillos en el aire?: paradigmas interpretativos "de moda" en la arqueología medieval española", De Mahoma a Carlomagno: los primeros tiempos (siglos VII-IX) /XXXIX Semana de Estudios Medievales, Estella, 17-20 de julio de 2012.

CoDOÑER, C. (coord.).: La Hispania visigótica y mozárabe: dos épocas en su literatura, Salamanca: Ediciones Universidad de Salamanca, 2010.

Collins, R.: "Julian of Toledo and the Royal Succession in Late Seventh-Century Spain", en WoOD, I. Y SAWYeR, P. (eds.): Early Medieval Kingship, Leeds: University of Leeds, 1977.

Collins, R.: Early medieval Spain. Unity in diversity (400- 1000), Hampshire-Londres, Mac Millan Press, 1995.

Collins, R.: La conquista árabe 710-797, España: Editorial Crítica, 1991.

Collins, R.: La Europa de la Alta Edad Media, Madrid: Akal, 2000.

Collins, R.: La España Visigoda 409-711, Barcelona, Crítica, 2005.

Collins, R.: Califas y reyes. España, 796-1031, Barcelona, Crítica, 2013.

CROUCH, J.: "Isidore of Sevilla and the Evolution of Kingship in Visigothic Spain", Mediterranean Studies, 4, 1994, pp. 9 -26.

Da GracA, L. y Zigarelli, A. (eds.): Studies on Pre-Capitalist Modes of Production, Historical Materialism Book Series, 97, Leiden: Brill, 2015.

DAVIS, J. R.: Charlemagne's practice of empire, Cambridge: Cambridge University Press, 2015.

DAVISON, N.: “Centuries of Transition”, Historical Materialism, vol. 19, 2011.

De PALOL, P.: "Las excavaciones del conjunto de $<$ El Bolavar $>$, Seros (Segria, Lérida) y el reino de Akhila", Los visigodos. Historia y civilización. Antigüedad y cristianismo (Murcia) III, 1996.

Dell' EliCine, E.: “La ley, el rey, la iglesia: un recorrido sobre las temáticas y debates en el campo de los estudios visigodos", Temas medievales [online]. 2009, vol.17, pp. 7-35. 
Dell' Elicine, E.: "Pensando al rey: los puntos de vista de la iglesia visigoda acerca de la institución monárquica (589- 711), Cuadernos medievales, Mar del Plata- Bahía Blanca, 2009, pp. 29-45.

Dell' Elicine, E.: "Si queremos evitar la ira divina: Impacto y vicisitudes del proyecto eclesiológico de Isidoro de Sevilla (c. 630- 690)", Espacio, Tiempo y Forma, Serie III, $H^{\circ}$ Medieval, 24, 2011, pp. 69-90.

DePreuX, P.: Les Sociétés occidentales du milieu du vie à la fin du ixe siècle, Rennes: Presses universitaires de Rennes, 2015.

DeVroey, J.P.: Économie rurale et société dans l'Europe franque (Vie-Ixe siècles), t. 1, Paris: Belin, 2003.

DiAgo JiMÉnEZ, J.M.: "Las instituciones educativas de carácter religioso en el reino hispanovisigodo de los siglos VIy VII a través de los cánones conciliares y las reglas monásticas”, Espacio Tiempo y Forma. Serie III, Historia Medieval, 31, 2018.

DíAz Martínez, P. C.: "Redimuntur captiui. A propósito de Regula Communis IX”, Gerión. Revista de Historia Antigua, vol. 10, 1992.

DíAz MARTínEZ, P.C.: "Rey y poder en la monarquía visigoda”, Iberia, No1, 1998a.

DÍAz MARTínEZ, P.C.: "El testamento de Vicente: Propietarios y dependientes en la Hispania del s. VI", "Romanización" y "reconquista" en la Península Ibérica: nuevas perspectivas, 1998b, pp. 257-270.

DÍAZ MARTíneZ, P.C.: "Visigothic political institutions", en HEATHER, P. (ed.): The Visigoths from the migration period to the seventh century, Woodbridge: The Boydell Press, 1999.

DíAz MARTínEZ, P.C.: "Sumisión voluntaria: estatus degradado e indiferencia de estatus en la Hispania visigoda (FV 32)”, Studia historica. Historia antigua, 25, 2007, (Ejemplar dedicado a: Resistencia, sumisión e interiorización de la dependencia), pp.507-524.

DíAz Martínez, P.C.: Hispania tardoantigua y visigoda, Madrid, Istmo, 2007.

DÍAz Martínez, P.C.: "Los godos como epopeya y la construcción de identidades en la historiografía española”, en Anales de Historia Antigua, Medieval y Moderna, Buenos Aires, 2008, vol. 40, pp. 25-73.

DíAz MARTínez, P.C.: “El reino visigodo en vísperas del 711: sistema político y administración”, Zona arqueológica, 15, 2011.

DíAz MARTíneZ, P.C.: El reino suevo (411-585), Madrid: Akal , 2011. 
DíAz Martínez, P. C.: "Confiscations in the Visigothic Reign of Toledo: A Political Instrument", en PorenA, P. Y RIVIERE, Y. (eds): Expropiations et confiscations dans les royaumes barbares. Une approche régionale, Roma: École Française de Rome, 2012, pp. 93-112.

DíAz MARTínez, P.C.: "La dinámica del poder y la defensa del territorio: para una comprensión del fin del reino visigodo de Toledo", De Mahoma a Carlomagno: los primeros tiempos (siglos VII-IX) /XXXIX Semana de Estudios Medievales, Estella, 17-20 de julio de 2012.

DíAz Martínez, P. C y I. Martín Viso, I.: "Una contabilidad esquiva: las pizarras numerales visigodas y el caso de el cortinal de San Juan (Salvatierra de Tormes, España)", en Entre el impuesto y la renta. Problemas de la fiscalidad tardoantigua y altomedieval, Bari: Edipuglia, 2011.

Díaz Martínez, P. C. y PovedA, P.: “Qui patrie excidium intulerunt. Hispania 711: explicaciones desesperadas para un colapso inesperado", Reti Medievali, 17/2, 2016, 1-28.

Díaz Martínez, P.C y VAlVerde CAStro, Ma.R: "The theoretical strength and practical weakness of the visigothic monarchy of Toledo", en THEUWS, F. AND NELSON J.L., (eds.), Rituals of power, from Late Antiquity to the Early Middles Ages, Leiden; Boston; Köln: Brill, 2000. (The transformation of the Roman world; Vol. 8).

DÍAZ Y DíAZ, M.C.: De Isidoro al siglo XI, Barcelona: El Albir Ediciones S.A, 1976.

DÍAZ Y DÍAZ, M.C: "Noticias históricas en dos himnos litúrgicos visigodos”, Los Visigodos. Historia y civilización Antigüedad y Cristianismo, III, Murcia, 1986.

DomíngUEZ DEL VAL, U.: Historia de la antigua literatura latina hispano-cristiana, vol. 4, Madrid: Fundación Universitaria Española, 1998, pp. 389-412.

DopsCH, A.: Fundamentos económicos y sociales de la cultura europea (de César a Carlomagno), México: Fondo de Cultura Económica, 1986.

D’ors, A.: “Los leudes de LV Antiqua 4, 5, 5”, AHDE, XXIV, 1954.

DuBY, G.: Guerreros y campesinos: Desarrollo inicial de la economía europea (500-1200), México: Siglo XXI, 1976.

Durlat, J.: Les finances publiques de Dioclétian aux Carolingiens (284-888), Sigmaringe, Beihefte der Francia XXI, 1990. 
EMERICH, F., "Cultura y sociedad en la sociología de Max Weber", Congreso de Sociología de la ciudad de Heidelberg, Universidad Ludwing-Maximilian, 1964. Conferencia dictada en Munich por motivo del centenario del nacimiento de Weber.

Escalona Monge, J.: Sociedad y territorio en la Alta Edad Media castellana: la formación del alfoz de Lara, Oxford: BAR, 2002.

Escalona Monge, J.: "Patrones de fragmentación territorial: el fin del mundo romano en la Meseta del Duero", en Espinosa, U. y CAstellanos, S. (eds.): Comunidades locales y dinámicas de poder en el norte de la península ibérica durante la Antigüedad tardía, Logroño: Universidad de La Rioja, 2006. pp. 165-199.

ESCALONA Monge, J.: "Conflicto religioso y territorialidad en un mundo en fragmentación: un ensayo comparativo del noroeste hispánico y Britania en los siglos IV-VI", en Castellanos, S. y Martín Viso, I. (eds.): De Roma a los bárbaros. Poder central y horizontes locales en la cuenca del Duero, León: Universidad de León, 2008, pp. 171-204.

Espinosa Ruiz, U.: "Buscando al San Millán histórico, el yacimiento de Parpalinas", Belezos: Revista de cultura popular y tradiciones de La Rioja, 2010.

FELLER, L.: Campesinos y señores en la Edad Media: Siglos VIII-XV, Valencia: Universitat de València, 2015.

FERNÁNDEZ, D.: “What is the Fisco Barcinonensi about?", Antiquité Tardive, 14, 2006, pp. 217-224.

FERNÁNDEZ, D.: "Property, Social Status, and Church Building in Visigothic Iberia", en Journal of Late Antiquity, 9, 2, Fall 2016, pp. 512-541

FERNÁNDEZ, D.: Aristocrats and Statehood in Western Iberia, 300-600 C.E., Philadelphia: University of Pennylvania Press, 2017a, pp. 8 y ss.

FERNÁNDEZ, D.: "Desigualdad económica, propiedad rural y cultura material en la Antigüedad Tardía. El caso de la Península Ibérica (siglos IV-VII)", CAmpagno, M., Gallego, J. García Mac Gaw, C.G.: Capital, deuda y desigualdad. Distribuciones de la riqueza en el Mediterráneo antiguo, Buenos Aires: Miño y Dávila, 2017b.

FERNÁNDEZ UbiÑA, J.: "Clasicismo y fin del mundo antiguo", en "Romanización" y "reconquista" en la Península Ibérica: nuevas perspectivas, 1998, pp.191-213.

FERreIro, A.: The visigoths in Gaul and Spain (a.D. 418- 711). A bibliography, Leiden: Brill, 1988. 
FERrEIRO, A.: The Visigoths in Gaul and Iberia. A Supplemental Bibliography, 1984-2003. The Visigoths in Gaul and Iberia (Update). A Supplemental Bibliography, 2004-2006, Leiden: Brill (The Medieval and Early Modern Iberian World, 28 y 35), 2006.

FERreIro, A.: The Visigoths in Gaul and Iberia (Update). A Supplemental Bibliography, 2007-2009, Leiden: Brill, 2011.

FERreIro, A.: The Visigoths in Gaul and Iberia (Update). A Supplemental Bibliography, 2010-2011, Leiden: Brill, 2014.

FOnTAINE, J.: "Quelques observations sur les Institutiones disciplinae”, Ciudad de Dios, 181, 1968, pp. 617-655.

FOnTAINE, J.: "Une épitaphe rythmique d'un contemporain d'Isidore de Séville: l'éloge funèbre du Visigot Oppila", en Van Uytfanghe, M. y Demeulenaere, R. (eds.): Aevum inter utrumque: Mélanges offerts à Gabriel Sanders, professeur émérite à l'Université de Gand, Turnhout: Brepols Publishers, 1991, pp. 163-186.

FOnTAINE, J.: Isidoro de Sevilla: Génesis y originalidad de la cultura hispánica en tiempo de los visigodos, Madrid: Ediciones Encuentro, 2002.

FossIER, R.: La sociedad medieval, Barcelona: Crítica, 1996.

FourACRE, P. ET AL. (ed.): The new Cambridge medieval history, Cambridge: Cambridge University Press, 2005.

FrighetTO, R.: “O soberano ideal na obra de Valério do Bierzo”, Gerión, 16, 1998, pp. 461470.

FRIGHETtO, R.: “Infidelidade e Barbárie na Hispania Visigoda”, Gerión, Vol. 20, № 1, 2002, pp. 491-510.

FRIGHETtO, R.: “O problema da legitimidade e a limitaçao do poder régio na Hispania visigoda: o reinado de Ervígio (608-687)”, Gerión, 2004, 1, pp 421-435.

FRIGHETTO, R.: "Incauto et inevitabili conditionum sacramento: juramento de fidelidad y limitaci ón del poder regio en la Hispania visigoda en el reinado de Egica (688)." Intus Legere Historia [En línea], 1.1-2, 2007, pp. 67-79.

Fuentes HinOJO, P.: "La pareja real y los problemas sucesorios en los reinos romanobárbaros", La familia en la edad media: XI Semana de Estudios Medievales, Nájera, del 31 de julio al 4 de agosto de 2001, pp. 455-470. 
Fuentes Hinojo, P.: "Patrocinio eclesiástico, rituales de poder e historia urbana en la Hispania tardoantigua (siglos IV al VI)", Studia Historica, Historia antigua., vol. 26, 2008, pp. 315-344.

FuENTES HinOJO, P.: "Sucesión dinástica y legitimidad episcopal en la Mérida visigoda”, En la España medieval, 35, 2012, pp. 11-33.

García Gallo, A.: Curso de Historia del Derecho español, Madrid, 1956.

García Gallo, A.: Manual de historia del derecho español, vol 1, Madrid: Artes Gráficos, 1975.

García Herrero, G.: “Julián de Toledo y la realeza visigoda”, Antigüedad y Cristianismo, VIII, 1991, 201-256.

García Moreno, L.A., “Algunos aspectos físcales de la Península Ibérica durante el siglo VI”, Hispania Antiqua, 1, 1971, pp.235-243.

GARCÍA MorenO, L. A.: "Estudios sobre la organización administrativa del reino visigodo de Toledo", Anuario de Historia del Derecho Español, t. XLIV, Madrid, 1974.

García MorenO, L.A.: "Composición y estructura de la fuerza de trabajo humana en la Península Ibérica durante la Antigüedad Tardía”, Memorias de Historia Antigua, Oviedo, 1977, pp. 247-256.

GARcía MorenO, L. A.: "El término sor y relacionados en el Liber Iudicum: de nuevo el problema de la división de las tierras entre godos y provinciales", Anuario de historia del derecho español, 1983, 53, p. 138-177.

GARCíA MORENO, L.A.: "El campesino hispanovisigodo entre bajos rendimientos y catástrofes naturales. Su incidencia demográfica", Los visigodos. Historia y civilización. Antigüedad y Cristianismo, Murcia, IK1, 1986.

GARCía Moreno, L.A.: Historia de la España visigoda, Madrid: Cátedra, 1989.

García Moreno, L. A.: "El estado protofeudal visigodo: precedente y modelo para la Europa carolingia", en L'Europe héritière de l'Espagne wisigothique [en línea], Madrid, Casa de Velázquez, 1992 (generado el 07 juin 2019). Disponible en Internet: $<$ http://books.openedition.org/cvz/2107>. ISBN: 9788490960981.

García Moreno, L. A.: "From coloni to servi. A History of the Peasantry in Visigothic Spain”, Klio. Beiträge zur alten Geschichte, vol. 83, 2001, p. 198-212 
GArcía MorenO, L.A.: "Estirpe goda y legitimidad del poder en tiempos de Sancho el Mayor", Ante el Milenario del reinado de Sancho el Mayor. Un rey navarro para España y Europa, XXX Semana de Estudios Medievales, Estella 14-18 julio 2003, Gobierno de Navarra, Pamplona, 2004.

GARCÍA Moreno, L.A.: Leovigildo: unidad y diversidad de un reinado, Madrid: Real Academia de Historia, 2008.

García Moreno, L. A.: "Prosopography, Nomenclature, and Royal Succession in the Visigothic Kingdom of Toledo “, Journal of late antiquity, vol. 1, 2008, pp. 142-156.

GASPARRI, S.: "Il tesoro del re", en GELICHI, S. (ed.): Tesori: forme di accumulazione della ricchezza nell'alto Medioevo (secoli V-XI), Roma: Viella, 2004.

GAUTIER, A.: "Les activités compétitives au sein des bandes armées de l'Europe du Nord au Haut Moyen Age", en Bougard, F., Le Jan, R y Lienhard, T. (eds.):Agôn. La compétition, Ve-XIIe siècle., Turnhout: Brill, 2012, (Haut Moyen Âge, 17), p. 75-92.

GAUTIER, A.: "La competición en bandas armadas en Europa del Norte durante la Alta Edad Media”, Sociedades Precapitalista. Revista de Historia Social, vol. 3, 1, diciembre 2013.

GÁZQUEZ, J.M.: "Sobre el origen hispano-visigodo de las Institutionum disciplinae", Faventia, 1979, pp. 35-46.

GELICHI, S. (ed.): Tesori: forme di accumulazione della ricchezza nell'alto Medioevo (secoli $V$-XI), Viella, 2004.

GELICHI, S. Y LIBRENTI, M.: 'L' edilizia in legno altomedievale nell' Italia del nord: alcune osservazioni”, I Congresso Nazionale di Argheologia Medeiivale (Pisa, 29-31 mayo 1997), Florencia, pp. 215-220.

GuIANCE, A.: “Rex perditionis. La caracterización de la tiranía en la España visigoda”, Cuadernos de Historia de España, 2000-2001, pp. 77, 29-40.

GuiAnCE, A.: "De reyes y santos: las manifestaciones de la monarquía en la hagiografía castellana (siglos VII-XI), Acta historica et archaeologica mediaevalia, 22, 2001, pp. 9-30. Gillet, A. (ed.): On Barbarian Identity. Critical Approaches to Ethnicity in the Early Middle Ages, Turnhout: Brepols, 2002. 
GlucksmanN, C.: “Modo de producción, formación económica y social, teoría de la transición a propósito de Lenin”, en LUPORINI, C. Y SERENI, E. (eds.): El concepto de “formación social”, México: Cuadernos de Pasado y Presente 39, 1973.

GODELIER, M.: Economía, fetichismo y religión en las sociedades primitivas, Madrid: Siglo XXI, 1974.

Godelier, M.: El enigma del don, Barcelona: Paidós, 1998.

Godoy, Y.: Gosvinta. La Regina dei Visigoti (525 ca.-589), Milano: Jaca Book, 2004.

Goetz, H.W, Jarnut, J. Y Pohl, W.: Regna and Gentes. The Relationship between Late Antique and Early Medieval Peoples and Kingdoms in the Transformation of the Roman World, Leiden-Boston-Colonia: Brill, 2003

GOFFART, W.: Barbarians and Roman A-D 418-584. The techniques of accommodation. Princeton, 1980 y “Los bárbaros en la Antigüedad tardía y su instalación en Occidente.”, en Little, L.; Rosenwein, W., (eds.), La Edad Media a debate, Madrid: Akal, 2003, pp.50-79. GonZÁlez BlAnCO, A.: "El decreto de Gundemaro y la historia del siglo VII”, Los visigodos. Historia y civilización. Antigüedad y cristianismo, Murcia, 1986.

GonZÁlez SAlinero, R.: Introducción a la Hispania visigoda, Madrid: Uned, 2018.

GREY, C.: Constructing Communities in the Late Roman Countryside, New York: Cambridge University Press, 2011.

GrIERSON, P.: "Commerce in the Dark Ages: a Critique of the Evidence", Transactions of the Royal Historical Society, 5th Series, 9, pp. 123-140.

GuREVICH, A.: “Représentations et attitudes à l'égard de la propriété pendant le Haut Moyen Age", Annales E.S.C., EHESS, 27, 1972.

GureVICH, A.: Las categorías de la cultura medieval, Madrid: Taurus, 1990.

HALSALl, G.; Warfare and society in the Barbarian West, 450-900, Londres: Routledge, 2003.

HALSALl, G.: Las migraciones bárbaras y el occidente romano, 376-568, Valencia: Univeritat de Valéncia, 2012.

HARDT, M.: "Royal Treasures and Representation in the Early Middle Ages", en PoHL, W. Y ReIMITZ, H. (eds.): Strategies of Distinction. The Construction of Ethnic Communities, 300800. Serie Transformation of the Roman World 2, Leiden: Brill, 1998. 
HARMAN, C.: “Chris Wickham's Framing the Early Middle Ages”, Historical Materialism, vol. 19, 2011.

HARPER, K.: Slavery in the Late Roman World. AD 275-425. Cambridge: Cambridge University Press, 2011.

HeATHER, P. (ed.): The Visigoths from the migration period to the seventh century, Woodbridge: The Boydell Press, 1999.

HeAther, P.: La caída del Imperio Romano, Barcelona: Crítica, 2006.

HeIss, A.: Description génerale des monnaies des rois wisigoths d'Espagne, París, 1872.

Hillagarth, J.: "Coins and Chronicles: Propaganda in Sixth-Century Spain and the Byzantine Background", Historia: Zeitschrift für Alte Geschichte, 1966, pp. 483-508.

Hillagarth, J.N: “Historiography un Visigothic Spain”, Settimania Stud Sull' Alto Medievo XVII, Spoleto, 1970.

ISLA FREZ, A.: "Las relaciones entre el reino visigodo y los reyes merovingios a finales del siglo VI”, En la España medieval, 13, 1990, pp. 11-32.

IsLA Frez, A.: “'Villa, villula, castellum': Problemas de terminología rural en época visigoda", Arqueología y territorio medieval, 8, 2001.

ISLA FreZ, A.: "Los fugitivos y el título sobre ellos del Liber Iudicum”, Arqueología y territorio medieval 8, 2001.

ISLA FREZ, A.: "El officium palatinum visigodo. Entorno regio y poder aristocrático", Hispania: Revista española de historia, 212, 2002, pp. 823-847.

IsLA FreZ, A.: "Reinas de los godos", Hispania, vol. LXIV, 2004.

ISLA FREZ, A.: "El lugar de habitación de las aristocracias en época visigoda, siglos VI-VIII", Arqueología y territorio medieval, 14, 2007.

ISLA FreZ, A.: Ejército, sociedad y política en la Península Ibérica entre los siglos VII y XI, Madrid: CSIC, 2010.

Jiménez GarnicA, A. M.: Nuevas Gentes, Nuevo Imperio: Los Godos y Occidente en el siglo $V$, Madrid: UNED, 2010.

KELLY, M.: "Recceswinth's Liber Iudiciorum: History, Narrative and Meaning”, en AA.VV.: Symposium 1, 2016-2017: Law and Theology, Network and Neighbors, pp. 110-130. online : https://visigothicsymposia.org/symposia/.

KING, P.D.: Derecho y sociedad en el reino visigodo, Madrid: Alianza, 1981. 
KirChNER, H.: "Sobre la arqueología de las aldeas altomedievales", Studia Historica. Historia Medieval, 28, 2010, pp. 246-247.

KocH, M.: "La imperialización del Reino visigodo bajo Leovigildo: ¿es la "imitatio imperii" de Leovigildo la manifestación de un momento de cambio en la pretensión de poder y la ideología visigoda?", Pyrenae: revista de prehistòria $i$ antiguitat de la Mediterrània Occidental, Vol. 39, №. 2, 2008, pp. 101-117.

Koon, S. Y Wood, J.: "The Chronica Maiora of Isidore of Seville”, e-Spania [En ligne], 6, diciembre 2008 .

KoON, S. Y WoOD, J.: "Unity from disunity: law, rhetoric and power in the Visigothic kingdom", European Review of History: Revue européenne d'histoire, vol. 16, 6, 2009.

KuPER, J.: Key Thinkers, past and present, New York: Routledge, 2015.

LANSING, C. Y ENGLISH, E.D. (eds): A companion to the medieval world, vol. 16, John Wiley \& Sons, 2012

LE JAN, R. : "Satellites et bandes armés dans le monde franc (VIIe-Xe siècles)". En : Actes de congrès de la Société des historiens médiévistes de l'enseignement supérieur public. 18 congrès, Montpellier, 1987, pp. 97-105.

LE JAN, R.: Famille et pouvoir dans le monde franc (VIIe-Xe siècle). Essai d'anthropologie sociale, Paris: Publications de la Sorbonne, 1995.

LE JAN, R.: "Frankish giving or arms and ritual of power: continuity of arms and rituals of power in the carolingian period", en THEUWS, F. AND NELSON J.L., (eds.), Rituals of power, from Late Antiquity to the Early Middles Ages, Leiden; Boston; Köln: Brill, 2000. (The transformation of the Roman world; Vol. 8).

LE JAN, R.: "Prendre, accumuler, détruire les richesses dans les sociétés du haut Moyen Âge”, en Les élites et la richesse au Haut Moyen Âge, Turnhout: Brepols Publishers, 2010. LINDKVIST, T.: "Social and Political Power in Sweden, 1000-1300: predatory incursions, royal taxation and the formation of a feudal state", en SAMSON, R. (ed.), Social Approaches to Viking Studies, Glasgow: Cruithne, 1991, pp. 137-145.

LINE, P.: Kingship and State Formation in Sweden: 1130 - 1290, Leiden; Boston; Köln: Brill, 2007

LineHAN, P.: Historia e historiadores de la España medieval, Salamanca: Ediciones Universidad de Salamanca, 2012. 
LóPez Quiroga, J. \& Rodríguez MARTin, F.G.: "El < final> de las villae en Hispania I. La transformación de las pars urbana de las villae durante la Antigüedad Tardía", Portugalia, 21-22, 2000-2001.

LÓPEZ SÁNCHEZ, F: “La moneda del reino visigodo en Toledo: ¿Por qué? ¿Para quién?”, Mainake, ISSN 0212-078X, No. 31, 2009, pp. 175-186.

LORING, Ma. I., PÉREZ, S. Y Fuentes, P.: La Hispania tardorromana y visigoda. Siglos VVIII, Madrid: Editorial Síntesis, 2007.

LORING, Ma . I. Y FUENTES HiNOJO, P.: "Esclavitud y servidumbre en el tránsito del mundo antiguo al medieval", "Romanización" y "reconquista" en la Península Ibérica: nuevas perspectivas, 1998

LUPORINI, C. y SERENI, E. (eds.): El concepto de "formación social”, México: Cuadernos de Pasado y Presente 39, 1973.

MagnAni, E.: "Les médiévistes et le don. Avant et après la théorie maussienne". Revue du MAUSS, 2007. En línea: http://www.journaldumauss.net/?Les-medievistes-et-le-don

Maíllo Salgado, F.: Acerca de la conquista árabe de Hispania: imprecisiones, equívocos y patrañas, Gijón: Trea, 2011.

MARTin, C.: “L'historiographie des élites en Espagne”. Disponible en: https:/lamopdev.univ-paris1.fr/IMG/pdf/martin.pdf. Mimeo.

Martin, C.: La géographie du pouvoir dans l'Espagne visigothique, Francia: Presses Universitaires du Septentrion, 2003.

MARTIN, C.: "Des fins de règne incertaines: répression et amnistie des groupes aristocratiques dans le royaume de Tolède (deuxième moitié du VIIe s.) ", en Bourgard, F., FELLER, L y LE JAN, R. (eds.): Les élites au haut Moyen Âge. Crises et renouvellements, Turnhout: Brepols, 2006.

MARTIN, C.: "Hiérarchie et service dans le monde wisigothique: la militia des laics", en Bougard, F., IOGNA-Prat, D. YLE JAN, R. (eds.): Hiérarchie et stratification sociale dans l'Occident médiéval (400-1100), Turnhout: Brepols Publishers, 2008a, pp. 325-341.

MARTIN, C.: "L'innovation politique dans le royaume de Tolède: le sacre du souverain", en PÉNEAU, C. (ed.), Elections et pouvoirs politiques du VIIe au XVIIe siécle, 2008b, pp. 281300. 
MARTIN, C.:"La notion de gens dans la péninsule Ibérique des VI-VIIe s.: quelques interprétation", en GAZEAU, V., BAUdUIN, P., MOdÉRAN, Y. (eds.):"Identité et ethnicité : concepts, débats historiographiques, exemples (IIIe-XIIe siècle)", Caen: Publications du CRAHM, 2008c, p. 75-89.

MARTíN IgLESIAS J.C. Y ANDRÉS SANZ, M.A.: Estudio crítico. Fructuoso de Braga, Madrid: Fundación Ignacio Larramendi, 2011.

MARTÍN IGLESIAS, J.C: "La biblioteca cristiana de los padres hispanovisigodos (siglos VIVII)", Veleia, 30, 2013, pp. 260-288.

Martín Iglesias, J.C.: "El latín de las Epistulae Wisigothicae", Cuadernos de Filología Clásica. Estudios Latinos, 34, 2014, pp. 37-60.

Martín Viso, I.: “Tributación y escenarios locales en el centro de la Península Ibérica. Algunas hipótesis a partir del análisis de las pizarras visigodas", Antiquité Tardive, 14, 2006, pp. 263-290.

MARTín Viso, I.: "<Tremisses y Potentes> en el nordeste de Lusitania (Siglos VI-VII)", Melanges de la Casa de Velázquez, 38, 1, 2008a (Ejemplar dedicado a: Actores de la Guerra de la Independencia), pp. 175-200.

MARTín VISO, I.: "La ordenación del territorio rural y la tributación en el suroeste de la Meseta del Duero (siglos VI-VII)", en CASTEllanos, S. y MARTín Viso, I. (eds.).: De Roma a los bárbaros. Poder central y horizontes locales en la cuenca del Duero, 2008b, pp. 227261.

MARTín VISO, I.: "Espacios sin estado. Los territorios occidentales entre el Duero y el Sistema Centra (siglos VIII-IX)”, en MARTín VISO, I. (ed.): ¿Tiempos oscuros? Territorio y sociedad en el centro de la Península Ibérica (siglos VII-X), Madrid: Silex, 2009.

MARTín VISO, I.: "Un mundo en transformación: los espacios rurales en la Hispania postromana (siglos V-VIII)", en CABAllero Zoreda, L., Mateos Cruz, P. y Cordero, T. (eds.), Visigodos y omeyas. El territorio. Anejos de Archivo Español de Arqueología, 61, 2011, pp. 31-63.

MARTín VISO, I.: "Circuits of Power in a Fragmented Space: Gold Coinage in the Meseta del Duero (sixth-seventh centuries)", en EsCALONA, J. Y REYNOLDS, A. (eds.): Scale and Scale Change in the Early Middle Ages: Exploring Landscape, Local Society, and the World Beyond, Turnhout: Brepols Publishers, 2011, pp. 215-252. 
MARTín ViSO, I.: "Enterramientos, memoria social y paisaje en la Alta Edad Media: propuestas para un análisis de las tumbas excavadas en roca en el centro-oeste de la Península Ibérica», Zephyrus, LXIX, 2012, pp. 165-187.

MARTín Viso, I.: "Hispania en el periodo postromano (siglos V-VIII)", en Monsalvo AnTón, J.M.: Historia de la España medieval, Salamanca: Ediciones Universidad de Salamanca, 2014.

MARTín VISO, I.: “Castra y elites en el suroeste de la Meseta del Duero post-romana”, en Catalán Ramos, R., Fuentes Melgar, P., Sastre Blanco, J.: Fortificaciones en la tardoantigüedad: élites y articulación del territorio (siglos V-VIII d.C.), Madrid: La Ergástula, 2014.

MARTín VISO, I.: "Huellas del poder: pizarras y poblados campesinos en el centro de la península Ibérica (siglos V-VII)", Medievalismo: Boletín de la Sociedad Española de Estudios Medievales, 25, 2015.

MARTín VISO, I.: Asentamientos y paisajes rurales en el occidente medieval, Madrid: Síntesis, 2016a.

MARTín VISO, I.: “Colapso político y sociedades locales: el Noroeste de la península ibérica (siglos VIII-IX)", Reti Medievali Rivista, 2016b, 17, 2.

MARTín VISO, I. ET AL.: "La formación de un nuevo paisaje en el centro de la península ibérica en el periodo posromano: el yacimiento de La Genestosa (Casillas de Flores, Salamanca)", en Archivo Español de Arqueología, vol. 90, 2017.

MARTín VISO, I.: “Organización campesina y dominios políticos en la cuenca del Duero altomedieval", Sociedades Precapitalistas, 7(2), 2018.

MARTínez, B. B: La educación en la Hispania antigua y medieval, Madrid: Ediciones Morata, 1992.

MARTínEZ JimÉnEZ, J.: "The Rural Hinterland of the Visigothic Capitals of Toledo and Reccopolis, between the Years 400-800 CE”, en Authority and Control in the Countryside, Leiden, The Netherlands: Brill, 2018.

Martínez Jiménez, J. Y Tejerizo GarcíA, C.: "Central Places in the Post-Roman Mediterranean: Regional Models for the Iberian Peninsula”, Journal of Mediterranean Archaeology, 28, 1, 2015, pp. 105-132. 
MARX, K.: "Formas que preceden a la producción capitalista", en GODELIER, M. (comp.): Antropología y economía, Barcelona: Anagrama, 1976.

MCCORMICK, M.: Eternal victory. Triumphal rulership in Late Antiquity, Byzantium and the Early Medieval West, Cambridge: Past and Present Publications, Cambridge University Press, 1986.

MCCORMicK, M.: "Complexity, chronology and context in the early medieval economy", Early Medieval Europe, 12, 2003, p. 311.

Miceli, P.: Derecho consuetudinario y memoria. Práctica jurídica y costumbre en Castilla y León (siglos XI-XIV), Madrid: Universidad Carlos III de Madrid, 2012.

MíngueZ FERnÁNDEZ, J. M.: "En torno a la génesis de las sociedades peninsulares altomedievales: reflexiones y nuevas propuestas", Studia historica. Historia medieval, 22, 2004. (Ejemplar dedicado a: En memoria de Ángel Barrios García (1951-2005), pp.169-187. Mínguez FERnÁndeZ, J. M.: "En torno a la génesis de las sociedades peninsulares altomedievales: reflexiones y nuevas propuestas"; "Sociedad esclavista y sociedad gentilicia en la formación del feudalismo asturleonés", "Romanización" y "reconquista" en la Península Ibérica: nuevas perspectivas, 1998.

Mínguez FERnÁndeZ, J. M.: Las sociedades feudales, 1, Madrid: Nerea, 1994.

MCKitTerick, R.: "Politics", en The Early Middle Ages, Europe 400-1000, (ed. Rosamond McKitterick), New York: Oxford University Press, 2001

MCKITTERICK, R.: La alta Edad Media. Europa 400-1000, Barcelona: Crítica, 2002.

MCKITTERICK, R.: Charlemagne: The formation of a European identity. Cambridge: University Press, 2008.

Montenegro, J. y del CAstillo, A.: "Don Pelayo y los orígenes de la Reconquista: un nuevo punto de vista", Hispania, 180, 1992, pp. 5-32.

Moreland, J.: "Concepts of the early medieval economy”, en HANSEN, I. L. Y WiCKHAM, C. (eds.): The long eighth century, Leiden: Brill, 2000, pp. 1-34

Moreland, J.: “Land and Power from Roman Britain to Anlgo-Saxon England?”, Historical Materialism, vol. 19, 2011.

Moreno Resano, E.: "La representación épica del combate y de la muerte del guerrero en el epitafio de Opilano (año 642)”, Habis, 42, 2011, pp. 299-316. 
Moreno ReSANO, E.: "El título de senior en la Antigüedad tardía: un estudio de terminología institucional", Saldvie, 13-14, 2013-2014.

Morssel, J.: La aristocracia medieval. El dominio social en occidente (siglos $V-X V$ ), Valencia: Universitat de València, 2008.

NAVARro CORDERO, C.: "El giro Recarediano y sus implicaciones políticas: el catolicismo como signo de identidad del Reino Visigodo de Toledo", Ilu. Revista de ciencias de las religiones, $\mathrm{n}^{\mathrm{o}}$ 5, 2000, pp. 97-118.

Nelson, J. L.: «Elites in the Reign of Charlemagne», en Bougard, F., Goetz, H.-W., LE

JAN, R. (eds.) Théorie et pratiques des élites au Haut Moyen Âge. Conception, perception et réalisation sociale, Turnhout: Brepols Publishers, 2011, pp. 309-324.

Olmo-Enciso, L., CASTRO-PRIEGo, M.: “La época visigoda a través de la arqueología”, 711. Arqueología e historia entre dos mundos, Madrid: Museo Arqueológico Regional, Alcalá de Henares, 2012.

Olmo-Enciso, L., Castro-Priego, M., Diarte-Blasco, P.: "Beside and within the walls of Reccopolis: social dynamics and landscape transformations of a new Visigothic urban foundation", Groma, 3, 2018, doi: 10.12977/groma14.

ONG, W.: Oralidad y escritura. Tecnologías de la palabra, México: FCE, 2006.

ORLANDIS, J.: Historia de Los Concilios de la España Romana y Visigoda, Eunsa: Ediciones de la Universidad de Navarra, 1986.

ORLANDIS, J.: "La sucesión al trono en la monarquía visigoda", Estudios Visigóticos, 3, Roma, Madrid, 1962.

ORLANDIS, J.: Historia del Reino Visigodo Español, Madrid: Rialp, 1988.

ORLANDIS, J.: “Una reina visigoda: Goswintha”, Semblanzas visigoda, Madrid: Rialp, 1992. Petit, C.: “Consuetudo y mos en la Lex Visigotorum”, Recueils de la Société Jean Bodin, 52, 1990

PÉreZ, M.: "Las donaciones piadosas y el modelo del don", en ASTARITA, C. (comp.): La Edad Media; recorridos historiográficos, Buenos Aires, Editorial de la Facultad de Filosofía y Letras Universidad de Buenos Aires, 2015.

PÉREZ SÁnCHEZ, D.: "Problemas sociales del reino visigodo de Toledo", Studia historica. Historia antigua, 1, 1983, pp. 105-118. 
PÉrez SÁnchez, D.: El ejército en la sociedad visigoda, Salamanca: Universidad de Salmanca, 1985.

PÉREZ SÁNCHEZ, D.: "Defensa y territorio en la sociedad peninsular hispana durante la antigüedad tardía (ss. V-VII)", Studia historica. Historia antigua, 16, 1998 (Ejemplar dedicado a: Sociedades y fronteras en el Mundo Antiguo), pp. 281-300.

PÉREZ SÁNCHEZ, D.: “Las transformaciones de la Antigüedad Tardía en la Península Ibérica: Iglesia y fiscalidad en la sociedad visigoda", Studia historica. Historia antigua, 17, 1999 (Ejemplar dedicado a: Estudios de Economía Antigua en la Península Ibérica. Nuevas aportaciones), pp. 299-320

PÉREZ SÁNCHEZ, D.: "Legislación y dependencia en la España visigoda" "Romanización" y "reconquista" en la Península Ibérica: nuevas perspectivas, 1998, p. 227-246.

PÉREZ SÁnCHEZ, D.: "Las transformaciones de la Antigüedad Tardía en la Península Ibérica: Iglesia y fiscalidad en la sociedad visigoda", Studia historica. Historia antigua, 17, 1999 (Ejemplar dedicado a: Estudios de Economía Antigua en la Península Ibérica. Nuevas aportaciones), pp. 299-320.

PÉREZ SÁNCHEZ, D.: "Poder político y dominación social: la función justificativa de los ángeles en el mundo visigodo", Studia historica. Historia antigua, 26, 2008 (Ejemplar dedicado a: La ecúmene romana: espacios de integración y exclusión), pp. 187-217.

PÉREZ SÁnCHEZ, D.: "La idea del < buen gobierno> y las virtudes de los monarcas del reino visigodo de Toledo", Mainake, XXXI, 2009, pp. 217-227.

PETERSEN, L.: Siege warfare and military organization in the successor states (400-800). Byzantium, the West and Islam, (History of warfare; volume 91), Leiden-Boston: Brill, 2013. PIRENNE, H.: Mahoma y Carlomagno, Buenos Aires: Editorial Heliasta, [1935], 2013.

Pliego VÁzQuez, R.: “La Acuñación Monetaria en el Reino Visigodo de Toledo: el Funcionamiento de las Cecas", Els Tallers Monetaris: Organització I Producció, Museu Nacional D' art de Catalunya. 2008, pp. 117-141.

Pliego VÁzQuez, R.: La moneda visigoda: Historia monetaria del reino visigodo de Toledo (c. 569-711), Sevilla: Secretariado de Publicaciones, Universidad de Sevilla, 2009.

Pohl, W. Y ReImitz, H. (eds.): Strategies of Distinction. The Construction of Ethnic Communities, 300-800. Serie Transformation of the Roman World 2, Leiden: Brill, 1998. 
Pohl, W.: "El concepto de etnia en los estudios de la Alta Edad Media", en LitTle, L.; Rosenwein, W. (eds.): La Edad Media a debate, Madrid: Akal, 2003, pp.35-49.

PoHL, W.: "Social Cohesion, Breaks, and Transformations in Italy, 535-600", en BAlZAREtTI, R., BARrow, J. y SkINNER, P. (eds): Italy and Early Medieval Europe: Papers for Chris Wickham, Oxford, 2018.

POVEDA ARIAS, P.: "Relectura de la supuesta crisis del fin del reino visigodo de Toledo, una aproximación al reinado de Égica a través de sus fuentes legales", Anuario de historia del derecho español, 85, 2015.

Poyatos, F.: La comunicación no verbal, Madrid: Istmo, 1994.

QuiRós CASTILlo, J.A.: "La génesis del paisaje medieval en Álava: la formación de la red aldeana", Arqueología y territorio medieval, 13, 2006.

Quirós CAstillo, J. A., Vigil Escalera, A.: "Networks of peasant villages between Toledo and Uelegia Alabense, Northwestern Spain (Vth-Xth centuries)", Archeologia Medievale, 33, 2007a.

Quirós CAstillo, J. A.: "Las aldeas de los historiadores y de los arqueólogos en la Alta Edad Media del Norte Peninsular", Territorio, Sociedad y Poder, 2, $2007 \mathrm{~b}$.

Quirós CASTILlo, J.A: "La arqueología de las aldeas en el noroeste peninsular. Comunidades campesinas y poderes territoriales, siglo V-X", Monasterios, espacio y sociedad en la España cristiana medieval, XX Semana de Estudios Medievales, Nájera del 3 al 7 de Agosto, Gobierno de La Rioja, Logroño, 2010a.

Quirós CAstillo, J. A. (dir.): The Archaeology of villages in the Early Middle Ages, Bilbao: Universidad del País Vasco, 2010b.

Quirós CAstillo, J. A.: "Early medieval landscapes in northwestern Spain: local powers and communities, fifth-tenth centuries", Early Medieval Europe, 2011a, 19.3, pp. 285-311. Quirós CASTILlo, J. A.: "La arquitectura doméstica de los yacimientos rurales en torno al año 711", 711. Arqueología e historia entre dos mundos, Zona Arqueológica, 15. 2, 2011b, pp. 63-82.

Quirós CASTILlo, J.A.: "Defensive Sites of the Early Middle Ages in North-West Spain", en BAKER, J., BROOKES, S. Y REYNOLDS, S. (eds.): Landscapes of Defence in Early Medieval Europe, Studies in the Early Middle Ages (SEM 28), 2013a. 
Quirós Castillo, J.A. y BengoetXea Rementeria, B.: Arqueología III. Arqueología medieval y posmedieval, Madrid: Universidad Nacional de Educación a distancia, 2013b. Quirós CAstillo, J. A. y Vigil-Escalera, A.: “.: "Networks of peasant villages between Toledo and Uelegia Alabense, Northwestern Spain (V-Xth centuries)", Archeologia Medievale, XXXIII, 2006, pp. 79-128.

Quirós Castillo, J. A. Y Vigil-Escalera, A.: “Dove sono i visigoti?”, en Ebanista, C. Y RotiLi, M (eds.): Archeologia e storia delle migrazioni: Europa, Italia, Mediterraneo fra tarda età romana e alto medioevo, 2011, pp. 259-281.

Reydellet, M.: 'Les intentions idéologiques et politiques dans la Chronique d'Isidore de Séville", Mélanges d'archéologie et d'histoire, 82. 1, 1970, pp. 363-400.

REYDELlet, M.: La royauté dans la littérature latine de Sidoine Apollinaire à Isidore de Séville, Roma: École Française de Rome, 1981.

Revault D’ Allonnes, M.: El poder de los comienzos. Ensayos sobre la autoridad, Buenos Aires: Amorrortu, 2008.

RICHÉ, P.: Éducation et Culture dans l'Occident Barbare VIe-VIIe siecles, Paris:Éditions du Seuil, 1962.

RichÉ, P.: “L’éducation a l'époque wisigothique: les Institutionum disciplinae”, Anales Toledanos 3, 1971, pp. 171-180.

RiVera Recio, J. F.: San Julián, arzobispo de Toledo (s. VII). Época y personalidad, Barcelona: Editorial Amaltea, 1944.

Rives, J.B: “Germania”, en PAGÁn, V. E. (ed.): A companion to Tacitus, Reino Unido: Wiley-Blackwell, 2012.

Romero, J.L.: "San Isidoro de Sevilla. Su pensamiento histórico político y sus relaciones con la historia visigoda", Cuaderno de Historia de España, VIII, 1947.

RUCHESI, F. “Los bucellarii y el Imperio Romano: sus orígenes, empleo y la cuestión de la cohesión social de sus componentes", Studia Historica. Historia Antigua, 34, 2016, 167-188. Rufí CASAls, I., Bujons, N., Costa SolË, A.: "Estudio del aprovechamiento animal en el yacimiento de la villa romana del Pla de 1'Horta (Sarrià de Ter, Girona) a partir del registro arqueozoológico (s. II d.C.-V/VII d.C.)", Archaeofauna, 27, 2018, pp. 275-292.

SAHLINS, M.: "Poor man, rich man, big-man, chief: political types in Melanesia and Polynesia", Comparative Studies in Society and History, vol. 5, 3 (Apr. 1963), pp. 285-303. 
SAHLInS, M.: Economía de la Edad de Piedra, Madrid: Akal, 1987.

SALRACH, J. M.: "Del estado romano a los reinos germánicos. En torno a las bases materiales del poder del estado en la Antigüedad tardía y la Alta Edad Media”, De la Antigüedad al Medievo, siglos IV-VIII, Congreso de Estudios Medievales, Madrid: Fundación Sánchez Albornoz, 1993.

Salvador Oyonate, J. A., Wood, J., Caballero Cobos, A.: "Central Places, Local Elites and International Politics: The Highlands of Granada and Byzantine-Visigothic Conflict, 550-630”, Nottingham Medieval Studies, 62, 2018, pp. 1-32.

SALVADOR RuS, R.: "Unidad y paz en el reino visigodo. Dos aspectos del pensamiento político de Isidoro de Sevilla", Antiquité Tardive, 23, 2015, p. 81-94.

SÁnChez Albornoz, C.: En torno a los orígenes del feudalismo, Mendoza, 1942, t. 1.

SÁnChEZ Albornoz, C.: "Pervivencia y crisis de la tradición jurídica romana en la España goda", Viejos y nuevos estudios sobre las instituciones medievales españolas, II, Madrid, 1976.

SÁNCHEZ AlboRnOz, C.: En torno a los orígenes del feudalismo visigodo, (primera parte):

Fideles y Gardingos en la monarquía visigoda, Mendoza, 1942

SÁnChez Albornoz, C.: "El senatus visigodo. Don Rodrigo, rey legítimo de España". Cuadernos de Historia de España, Buenos Aires, 1947, pp. 5-99.

SÁnChEZ AlbornOz, C.: "El Aula Regia y las asambleas políticas de los godos”, Cuadernos de Historia de España, Buenos Aires, 1946, 5, pp. 6-110.

SÁNCHEZ AlbORnOZ, C.: "El precarium en Occidente durante los primeros siglos medievales", en Viejos y nuevos estudios sobre las instituciones medievales españolas, II, Madrid, 1947.

SÁnchez Albornoz, C.: El «Stipendium»Hispano-Godo y los orígenes del beneficio prefeudal. Buenos Aires, Instituto de Investigaciones Históricas. Departamento de Historia de España, 1947.

SÁnCHEz AlbornOz, C.: "Los leudes en la Lex Visigothorum”, Revista Chilena de Historia del Derecho, 1961, 2, pp. 11-21.

SÁNCHEZ AlbornOz C.: "La Ordinatio principis en la España goda y postvisigoda", Cuadernos de Historia de España, 35, 1962, pp. 5-36. 
SÁNCHEZ AlbornOz, C.: "España y el feudalismo carolingio", Viejos y nuevos estudios sobre las instituciones medievales españolas, II, Madrid, 1976.

SÁNCHEZ AlbORNOZ, C.: “¿Donaciones reales restringidas en la España goda y postvisigoda?", Separata Homenaje a Don José María Lacarra de Miguel en su jubilación del profesorado, Vol. I, Zaragoza, 1977.

SÁnchez de Puerta Trujillo, F.: "Los tipos ideales en la práctica: significados, construcciones, aplicaciones", EMPIRIA. Revista de Metodología de Ciencias Sociales, $\mathrm{n}^{\mathrm{o}}$ 11, enero-junio, 2006, pp. 11-32.

SÁNCHEZ-GUISANDE, J.N.: "El trasfondo político-religioso del enfrentamiento entre el rey Leovigildo y el obispo Masona de Mérida", Compostellanum: revista de la Archidiócesis de Santiago de Compostela, Vol. 51, 1-2, 2006, pp. 27-60.

SANTIAgO FERnÁNDEZ, J.: "El hábito epigráfico en la Hispania visigoda", VIII Jornadas Científicas sobre Documentación de la Hispania altomedieval: (siglos VI-C), Madrid: UCM, 2009.

SÁnCHEZ PARDO, J. C.: "Sobre las bases económicas de las aristocracias en la Gallaecia suevo-visigoda (ca. 530-650 d.C). Comercio, minería y articulación fiscal”, Anuario de Estudios Medievales, vol. 44, 2, 2014.

SÁNChEZ PRIETO, A.B: "Las Institutionum Disciplinae: programa educativo para un noble godo”, en Vergara Ciordia, J., SÁnchez Barea, F., y Comella Gutiérrez, B. (coords.): Ideales de formación en la Historia de la Educación, Madrid: Editorial Dykinson, 2011, pp. 87-104.

SANZ, R.: "Aproximación al estudio de los ejércitos privados en Hispania durante la antigüedad tardía”, Gerión, 1986, vol. 4, pp. 225-264.

SARACHU, P.: "Esclavos sin esclavismo: la inestabilidad de la explotación servil en el reino Burgundio", Circe, XV, 2011.

SARACHU, P.: “Guerra, relaciones de producción y economía en la Galia meridional postromana", Trabajos y comunicaciones, n. 38, 2012.

SARACHU, P.: Patronazgo rural, dependencia y sociedad de base campesina en la Galia meridional (c. 400-c. 550) (Tesis de posgrado). -- Presentada en Universidad Nacional de La Plata. Facultad de Humanidades y Ciencias de la Educación para optar al grado de Doctor en 
Historia. Disponible en: http://www.memoria.fahce.unlp.edu.ar/tesis/te.1176/te.1176.pdf, 2015

SARRIS, P.: Empires of Faith: The Fall of Rome to the Rise of Islam, 500-700, Oxford: Oxford University Press, 2011.

SERENI, E.: "La categoría de < formación económico- social>”, en LUPORINI, C. Y SERENI, E., E. (eds.): El concepto de "formación social", Cuadernos de Pasado y Presente 39, México, 1973: "La categoría de <formación económico- social>”, El concepto de "formación social", Cuadernos de Pasado y Presente, 39, México, 1973.

SERRANO GÓMEZ, E.: Legitimación y racionalización. Weber y Habermas: la dimensión normativa de un orden secularizado, México: Anthropos, 1994.

Smith, K, A.: War and the Making of Medieval Monastic Culture, Suffolk: The Boydell Press, 2013.

SOUVIRON BONO, S.: "Fiscalidad y control eclesiástico en la Hispania visigoda: supervisión de almas e impuestos", Baetica. Estudios de Arte, Geografia e Historia, vol. 31, Málaga, 2009. pp. 275-289.

StOcKING, R.: Bishops, councils, and consensus in the Visigothic Kingdom, 589-633, Michigan: The University of Michigan Press, 2003.

STOCKING, R. L.:"Review article: Continuity, culture and the state in late antique and early medieval Iberia", en Early Medieval Europe, 15 (3), 2007.

Teillet, S.: "L'Historia Wambae est-elle une oeuvre de circunstance?," Antigüedad y Cristianismo, III, 415-424.

TeILlet, S.: Des Goths à la nation gothique: les origines de l'idée de nation en Occident du Ve au VIIe siècle, París: Belles Lettres, 1984.

TEJERIZO-GARCÍA, C.: "Early medieval household archaeology in Northwest Iberia (6th-11th centuries)", Arqueología de la arquitectura, 9, 2012.

TEJerizo-García, C. et al.: "La construcción histórica de los paisajes en el sector central de la cuenca del Duero. Primeros resultados de una prospección intensiva”, Territorio, Sociedad y Poder, Revista de Estudios Medievales, 2015, $\mathrm{n}^{\circ} 10$.

TEJerizo-García, C. y CANOSA-BetÉs, J.: "Power, control and social agency in post-roman northern Iberia: an archaeological analysis of hillfort occupations", Journal of Medieval Iberian Studies, 10, 2018, pp. 295-323. 
ThOMPson, E.A.: The goths in Spain, Oxford: Oxford University Press , 1969.

Torres López, M.: “El estado visigótico", en Anuario de Historia del Derecho Español, T.III, 1926, pp.304-475.

TORres LóPez, M.: "El Derecho y el Estado", en Torres LÓPEZ, M. et al.: Historia de España. España visigoda (414-711 de J. C.), Madrid, 1980.

TYLER, E.M.: Treasure in the Medieval West, York: York Medieval Press, 2000.

UdAONDO PUERTO, F.J.: "El sistema escolar en la Hispania visigoda. El ejemplo de Valerio del Bierzo", Helmantica: Revista de filología clásica y hebrea, 54, 2003, pp. 391-445.

VAlverde Castro, $M^{a}$.R.: "Leovigildo: Persecución religiosa y defensa de la unidad del reino", Iberia: Revista de la Antigüedad, 2, 1999, pp. 123-132.

VALVERDE CASTRO, Ma.R.: Ideología, simbolismo y ejercicio del poder real en la monarquía visigoda: un proceso de cambio, Salamanca: Universidad de Salamanca, 2000.

VAlverde CAStro, Ma. R: "Monarquía y tributación en la Hispania visigoda: el marco teórico", Hispania Antiqva, 31, 2007, p. 235-251.

Valverde Castro, Ma.R: "Mujeres < viriles< en la Hispania visigoda. Los casos de Gosvinta y Benedicta”, Studia Histórica, Historia Medieval, Salamanca, n²6, 2008.

VelÁzQuez Soriano, I. y Ripoll, G.: “Isidoro y su época. A modo de introducción”, Antiquité Tardive, 23, 2015, pp. 43-45.

VelÁzQUEz SoRIANO, I.: "Wamba y Paulo: Dos personalidades enfrentadas y una rebelión”, Espacio, Tiempo y Forma, Serie II, $H^{\circ}$. Antigua, t. II, 1989, pp. 213-222.

VELÁzQUEZ SORIANO, I.: "Jurial relations as an indicator of syncretism: from de law of inheritance to the dum inclicita of Chindaswinth", en HEATHER, P. (ed.): The Visigoths from the Migration Period to the Seventh Century. An Ethnographic Perspective, Woodbridge: The Boydell Press, 1999.

VELÁZQUEZ SORIANO, I.: Las pizarras visigodas. (Entre el latín y su disgregación. La lengua hablada en Hispania, siglos VI-VIII), Real Academia Española, 2004.

VAllejo GiRvés, M.: Hispania y Bizancio: una relación desconocida, Madrid: Akal, 2012. Vigil-EsCALERA, A.: “Cabañas de época visigoda: evidencias arqueológicas al sur de Madrid. Tipología, elementos de datación y discusión”, Archivo Español de Arqueología, 2000, 73, pp. 223-252. 
Vigil-EsCALERA, A.: “Cerámicas tardorromanas y altomedievales de Madrid”, en Caballero, L. Mateos, P. Y Retuerce, M. (eds.): Cerámicas tardorromanas y altomedievales en la Península Ibérica. Ruptura y continuidad, 2003, Madrid, pp. 371-387. Vigil-EscalerA, A.: "Arquitectura de tierra, piedra y madera en Madrid (ss. V-IX d.C.). Variables materiales, consideraciones sociales”, Arqueología de la Arquitectura, 2, 2003. Vigil-EsCALERA, A.: "Nuevas perspectivas sobre la arqueología madrileña de época visigoda", Actas de las Primeras Jornadas de Patrimonio Arqueológico en la Comunidad de Madrid, 2005.

Vigil-EsCALERA, A.: "El modelo de poblamiento rural en la Meseta y algunas cuestiones de visibilidad arqueológica”, en LóPEz QuirogA, J., MARTínez TeJERA A. M. Y Morín, DE PABlos, J. (eds.): Galia e Hispania en el contexto de la presencia germánica (s. V-VII). Balance y perspectivas, Oxford: BAR, 2006, pp. 89-108.

VigIL-EsCALERA, A.:" Granjas y aldeas altomedievales al norte de Toledo (450-800 d C)", Archivo Español de Arqueología, 80, 2007.

Vigil-EsCALERA, A.: "Apuntes sobre la genealogía política de aldeas y granjas altomedievales", en MARTín VISO, I (ed.): ¿Tiempos oscuros? Territorios y sociedad en el centro de la Península Ibérica (siglos VII-X), Madrid: Sílex 2009, pp. 31-44.

VIGIL-EsCALERA, A.: "Las aldeas altomedievales madrileñas y su proceso formativo", en Quirós Castillo, J. A. (ed.): The Archaeology of villages in the Early Middle Ages, Bilbao, 2010, pp. 315-339.

VigIL-ESCALERA, A.: "Formas de poblamiento rural en torno al 711: documentación arqueológica del centro peninsular", 711. Arqueología e historia entre dos mundos, Zona Arqueológica, 15, 2011, p. 189-211.

VIGIL-EsCALERA, A.: “Is it really relevant the ethnicity of our historical subjects?", Arqueología y territorio medieval, 18, 2011, pp. 45-53.

Vigil-EscalerA, A.: Los primeros paisajes altomedievales en el interior de Hispania. Registros campesinos del siglo quinto d.C., Bilbao, 2015.

Vigil-Escalera, A., Quirós Castillo, J. A.: "Early Medieval rural societies in NorthWest Spain: Archaeological reflections of fragmentation and convergence", en EsCALONA, J. Y REYNOLDS, A. (eds.): Scale and Scale Changes in the Early Medieval Ages. Exploring Landscape, local Society and the World beyond, Turnhout, 2011. 
VILAR, P.: Pensar históricamente. Reflexiones y recuerdos, Barcelona: Crítica, 2004.

VizCAÍNO SÁNCHEZ, J.: "La presencia bizantina en "Hispania" (siglos VI-VII): la documentación arqueológica", Antigüedad y cristianismo: Monografías históricas sobre la Antigüedad tardía, 25, 2007.

WARD-PERKINS, B.: The fall of Rome and the end of civilization, Oxford: Oxford University Press, 2005.

Weber, M.: Economía y Sociedad, México:Fondo de Cultura Económica, 1987.

WenKus, R.: Stammesbildung und Verfassung. Das Werden der frühmittelalterlichen Gentes, Colonia/Graz: Böhlau, 1961.

WiCKHAM, C.: “La caída de Roma no tendrá lugar”, en LITTLE, L. K y ROSENWEIN, B.H. (ed.): La Edad Media a debate, Madrid: Akal, 2003, pp. 80-101.

WiCKHAM, C. “Tradiciones nacionales y el problema de la comparación” Anales de Historia Antigua, Medieval y Moderna, Buenos Aires, 2008, vol. 40, pp. 11-24.

WICKHAM, C.: "Problems of comparing rural societies in early medieval western Europe" en Land \& Power, Studies in Italian and European Social History, 400-1200, British School at Rome, Lodon, 1994, p. 201 y ss; Versión en español: "Problemas de comparación de sociedades rurales en la Europa occidental de la temprana Edad Media", Anales de Historia Antigua y Medieval, Buenos Aires, 1996, vol. 29, pp. 45 y ss.

WickHAM, C.: Una historia nueva de la Alta Edad Media, Europa y el mundo mediterráneo, 400-800, Barcelona: Crítica, 2008.

WickHAM, C.: "Productive Force and the Economic Logic of the Feudal Mode of Production", Historical Materialism, 16, pp. 3-22, 2008. Trad. WicKHAM, C.: "Fuerzas productivas y lógica económica del modo de producción feudal”, Sociedades Precapitalistas, vol. 1, 2, 1er semestre 2012.

http://www.sociedadesprecapitalistas.fahce.unlp.edu.ar/. Universidad Nacional de La Plata. Facultad de Humanidades y Ciencias de la Educación. Centro de Estudios de Historia Social Europea. (Trad. de Pablo Sarachu y Sabrina Orlowski).

WooD, I.: The Merovigian Kingdoms 450-751, London: Routledge , 2012.

Wood, J.: The Politics of Identity in Visigothic Spain: religion and power in the histories of Isidor of Seville, Leiden: Brill, 2012. 
Wood, J.: "Borders, Centres and Peripheries in late Roman and Visigothic Iberia", International Journal of Regional and Local History, 2015, 10:1, 1-17.

Wood, J. y Martínez JimÉneZ, J.: "New directions in the study of Visigothic Spain”, en History Compass 14.1, 29-38, 2016.

Wolf, E.: "Relaciones de parentesco, de amistad y de patronazgo en las sociedades complejas", en BANTON, M. (ed.): Antropología social de las sociedades complejas, Madrid: Alianza, 1980.

Wolfram, H.: History of the Goths, California, 1990.

Wolfram, H.: The Roman Empire and Its Germanic Peoples, Berkeley: University of California Press, 1997. 